\title{
Geologic Map of the Northern Harrat Rahat Volcanic Field, Kingdom of Saudi Arabia
}

By Drew T. Downs, Joel E. Robinson, Mark E. Stelten, Duane E. Champion, Hannah R. Dietterich, Thomas W. Sisson, Hani Zahran, Khalid Hassan, and Jamal Shawali

Pamphlet to accompany

U.S. Geological Survey Scientific Investigations Map 3428

Saudi Geological Survey Special Report SGS-SP-2019-2

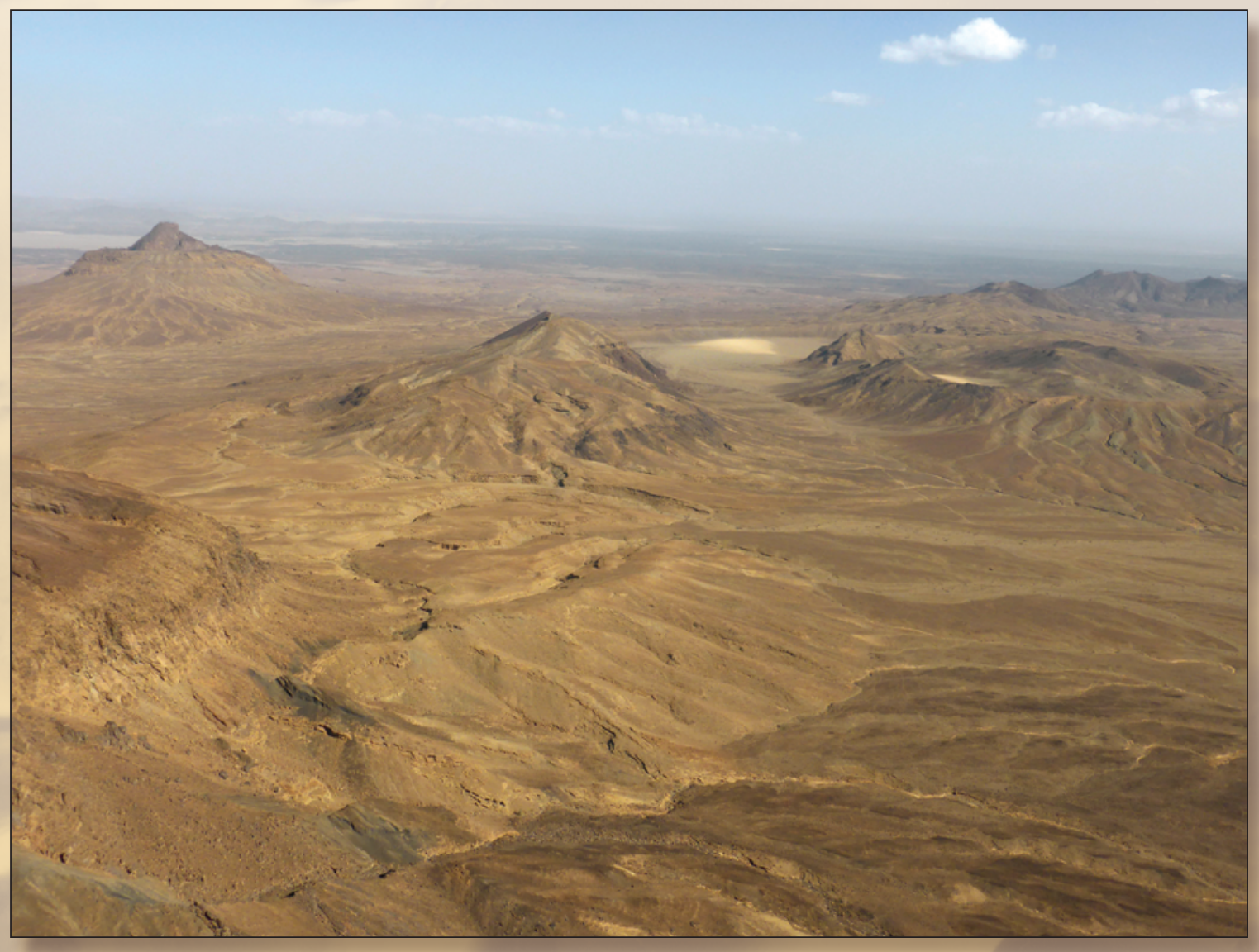

2019

U.S. Department of the Interior

U.S. Geological Survey 


\title{
U.S. Department of the Interior \\ DAVID BERNHARDT, Secretary
}

\author{
U.S. Geological Survey \\ James F. Reilly II, Director
}

U.S. Geological Survey, Reston, Virginia: 2019

For more information on the USGS - the Federal source for science about the Earth, its natural and living resources, natural hazards, and the environment—visit https://www.usgs.gov or call 1-888-ASK-USGS.

For an overview of USGS information products, including maps, imagery, and publications, visit https://store.usgs.gov.

Any use of trade, firm, or product names is for descriptive purposes only and does not imply endorsement by the U.S. Government.

Although this information product, for the most part, is in the public domain, it also may contain copyrighted materials as noted in the text. Permission to reproduce copyrighted items must be secured from the copyright owner.

Suggested citation:

Downs, D.T., Robinson, J.E., Stelten, M.E., Champion, D.E., Dietterich, H.R., Sisson, T.W., Zahran, H., Hassan, K., and Shawali, J., 2019, Geologic map of the northern Harrat Rahat volcanic field, Kingdom of Saudi Arabia: U.S. Geological Survey Scientific Investigations Map 3428 [also released as Saudi Geological Survey Special Report SGS-SP-2019-2], 65 p., 4 sheets, scales 1:75,000, 1:25,000, https://doi.org/10.3133/sim3428.

Associated data for this publication:

Robinson, J.E., Downs, D.T., Stelten, M.E., Champion, D.E., Dietterich, H.R., Sisson, T.W., Zahran, H., Hassan, K., and Shawali, J., 2019, Database for the geologic map of the northern Harrat Rahat volcanic field, Kingdom of Saudi Arabia: U.S. Geological Survey data release, https://doi.org/10.5066/P903WGTN.

ISSN 2329-1311 (print)

ISSN 2329-132X (online)

ISBN 978-1-4113-4291-0

Cover. Aerial view to southeast along domes, craters, and pyroclastic flow deposits in Al Efairia area of northern Harrat Rahat volcanic field, Kingdom of Saudi Arabia. Photograph by Andrew Calvert, 2014. 


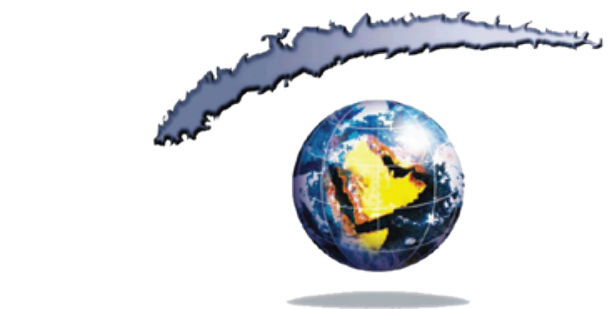

هيئة المسـاحـة الجيولو جية السمودية

SAUDI GEOLOGICAL SURUEY

\section{Ministry of Industry and Mineral Resources}

BANDAR ALKHORAYEF, Minister

\section{Saudi Geological Survey}

Khalid bin Saleh Al-Mudaifer, President

Saudi Geological Survey, Jeddah, Kingdom of Saudi Arabia: 2019 



\section{Contents}

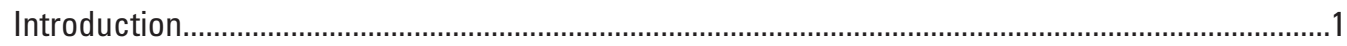

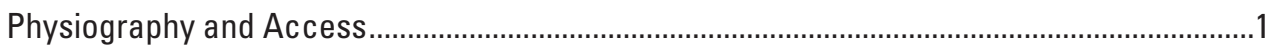

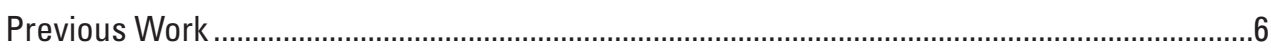

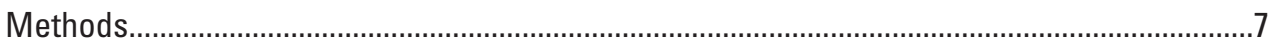

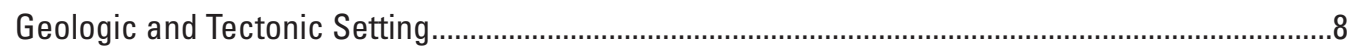

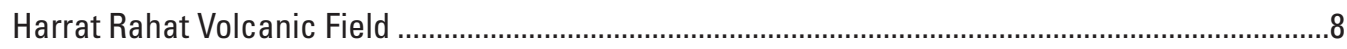

Compositions and Eruptive Styles of Volcanic Rocks..............................................................

Petrographic Characteristics of Volcanic Rocks ....................................................................11

Eruptive History of Northern Harrat Rahat and its Environs............................................................12

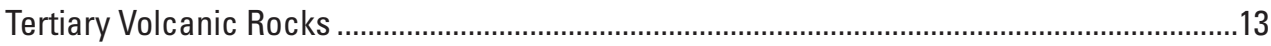

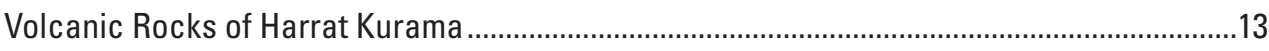

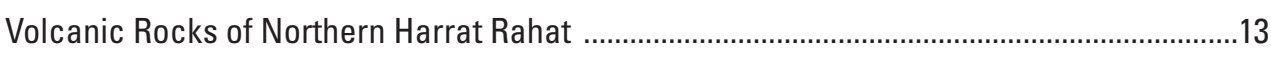

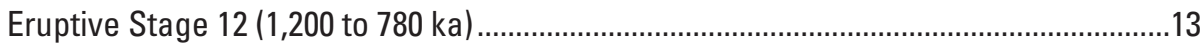

Eruptive Stage 11 ( 780 to $570 \mathrm{ka})$.............................................................................15

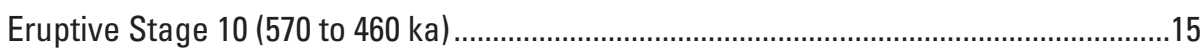

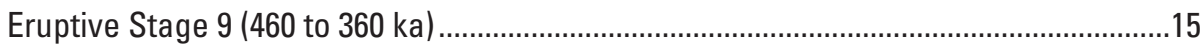

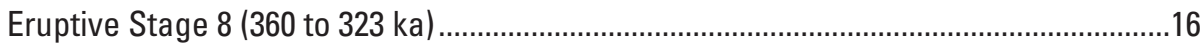

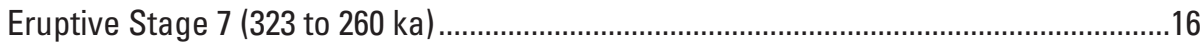

Eruptive Stage 6 (260 to $180 \mathrm{ka})$................................................................................

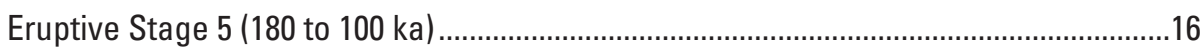

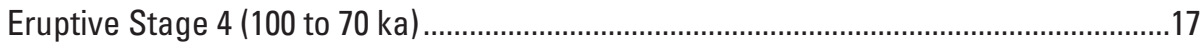

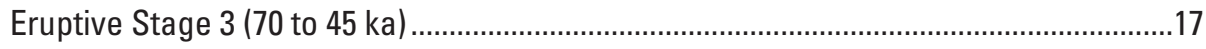

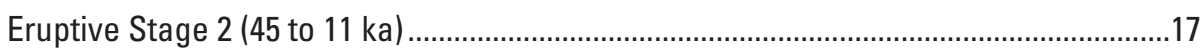

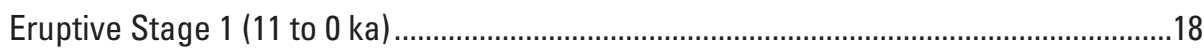

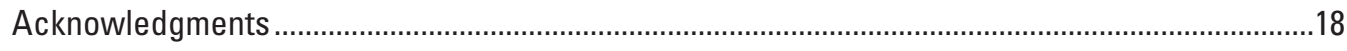

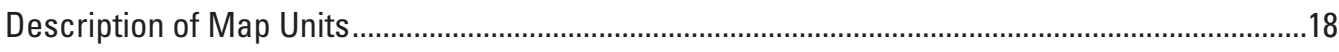

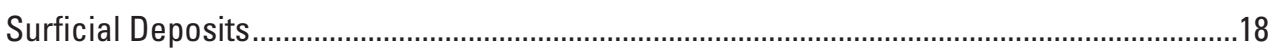

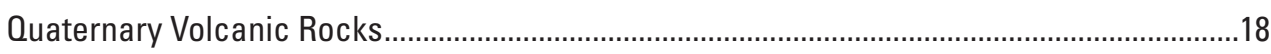

Volcanic Rocks of Northern Harrat Rahat ...............................................................19

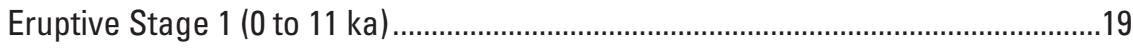

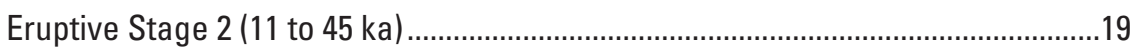

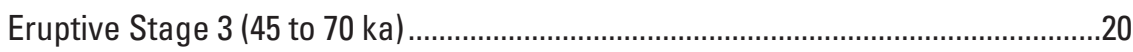

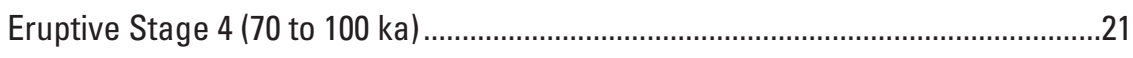

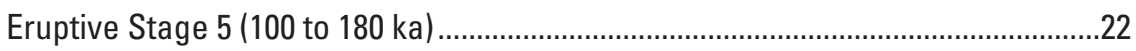

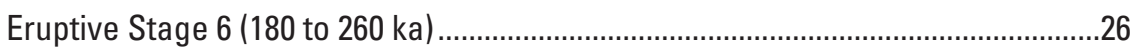

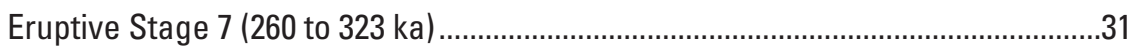

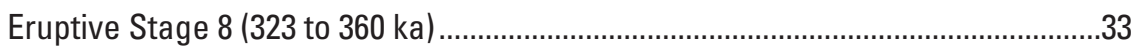

Eruptive Stage 9 (360 to $460 \mathrm{ka})$..........................................................................33

Eruptive Stage 10 (460 to $570 \mathrm{ka}$ ).........................................................................

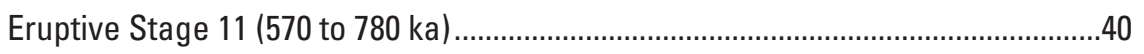

Eruptive Stage 12 (780 to 1,200 ka) .................................................................41

Volcanic Rocks of Harrat Kurama ...........................................................................

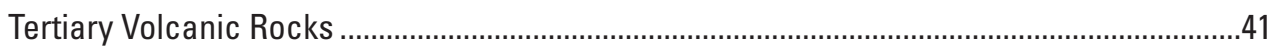

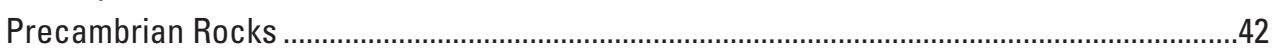

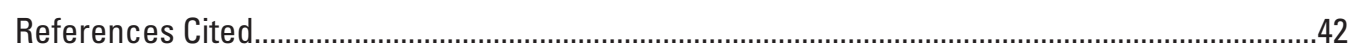




\section{Figures}

1. Map showing tectonic setting of Harrat Rahat volcanic field, as well as locations of continental, intraplate volcanic fields encompassed by Arabian plate........................2

2. Colored shaded-relief map of Harrat Rahat volcanic field.................................................

3. Shaded-relief map of northern Harrat Rahat volcanic field, showing distribution of volcanic-rock units and other units shown on sheet 1 . Figure is on sheet 4; caption included here for continuity..... ...sheet 4

4. Plots showing analyses of 661 volcanic rocks from northern Harrat Rahat volcanic field

5. Shaded-relief map of northern Harrat Rahat volcanic field, showing compositions of eruptive products. Also shown are locations of vents and approximate locations and trends of vent axes

6. Map of Harrat Rahat volcanic field, showing area of sheet 1 in relation to previously published geologic maps

7. Map showing tectonic setting of Arabian plate

8. Photograph to west-northwest, showing 1.9-km-long fissure vent that erupted the basalt of Central Finger. Figure is on sheet 4; caption included here for continuity sheet 4

9. Photograph to north-northwest, showing domes of the trachyte of Mouteen and the trachyte of Matan. Figure is on sheet 4; caption included here for continuity sheet 4

10. Photograph to southeast, showing pancake lava dome of the trachyte of Um Znabah 1. Behind it is high-standing scoria cone, vent for the mugearite of Um Znabah 2. To left of scoria cone is lava spine of the trachyte of Um Rgaibah. Figure is on sheet 4; caption included here for continuity

11. Photograph to southeast, showing crater that formed during eruption of the trachyte of Gura 3. Remnant of the basalt of Gura 3 is exposed on crater floor; visible in crater wall are the benmoreite of Gura 3 and the basalt of Ad Darah. Figure is on sheet 4; caption included here for continuity. sheet 4

12. Relative-probability distribution versus age for all ages in northern Harrat Rahat volcanic field; peaks and troughs were used to define 12 eruptive stages

\section{Tables}

1. Map units in northern Harrat Rahat volcanic field, showing their unit names, ages, and eruptive stages.

2. ${ }^{40} \mathrm{Ar} /{ }^{39} \mathrm{Ar}$ isotopic ages and analytical data for units in northern Harrat Rahat volcanic field

3. ${ }^{36} \mathrm{Cl}$ cosmogenic surface-exposure ages and analytical data for units in northern Harrat Rahat volcanic field

4. Paleomagnetic data for units in northern Harrat Rahat volcanic field

\section{Map Sheets}

1. Geologic Map of the Northern Harrat Rahat Volcanic Field, Kingdom of Saudi Arabia

2. Geologic Map of the Northern, Central, and Southern Fingers Lava Flows, Northern Harrat Rahat Volcanic Field, Kingdom of Saudi Arabia

3. Geologic Map of the Silicic Volcanic Centers Near Al Efairia, Al Wabarah, and Matan, Northern Harrat Rahat Volcanic Field, Kingdom of Saudi Arabia

4. Correlation and List of Map Units for the Geologic Map of the Northern Harrat Rahat Volcanic Field, Kingdom of Saudi Arabia 


\title{
Geologic Map of the Northern Harrat Rahat Volcanic Field, Kingdom of Saudi Arabia
}

\author{
By Drew T. Downs, ${ }^{1}$ Joel E. Robinson, ${ }^{1}$ Mark E. Stelten, ${ }^{1}$ Duane E. Champion, ${ }^{1}$ Hannah R. Dietterich, ${ }^{1}$ \\ Thomas W. Sisson, ${ }^{1}$ Hani Zahran, ${ }^{2}$ Khalid Hassan, ${ }^{2}$ and Jamal Shawali ${ }^{2}$
}

\section{Introduction}

The Harrat Rahat volcanic field, which is in the west-central part of the Kingdom of Saudi Arabia, is the largest of 15 harrats (Arabic for "volcanic field") hosted within the Arabian plate (fig. 1). Harrat Rahat is 50 to $75 \mathrm{~km}$ wide (east-west) and $300 \mathrm{~km}$ long (north-south), covering an area of approximately $20,000 \mathrm{~km}^{2}$ and encompassing more than 900 observable vents. The map on sheet 1 shows the volcanic geology of the northern part (about $3,340 \mathrm{~km}^{2}$ ) of Harrat Rahat (see fig. 2 for location of the map area within Harrat Rahat), at a scale of 1:75,000. Two additional maps highlight areas of interest at 1:25,000 scale (sheets 2, 3).

Northern Harrat Rahat is of interest owing to the location of the city of Al-Madinah Al-Munawarah (hereafter, referred to as Al-Madinah), which sits atop (and is recently expanding over) the north end of the volcanic field (Downs and others, 2018).

Al-Madinah is home to more than 1.5 million residents, and the city experiences an additional influx of approximately 3 million pilgrims annually. The downtown area of Al-Madinah is less than $8 \mathrm{~km}$ from lava flows of the only confirmed historical eruption (unit bla; included in red-shaded area [eruptive stage 1] on fig. 3, on sheet 4), which occurred in 1256 C.E. (Al-Samhoody, 1486; Camp and others, 1987; Camp and Roobol, 1991; Kawabata and others, 2015; Kereszturi and others, 2016; Murcia and others, 2017; Dietterich and others, 2018; Downs and others, 2018).

Mapping was undertaken by the U.S. Geological Survey (USGS) in collaboration with the Saudi Geological Survey (SGS) as part of a project entitled "An Agreement for Implementing a Volcano and Seismic Hazard Evaluation and Mitigation in the Al-Madinah Region (Northern Harrat Rahat)." The features of primary interest within the map area are scoria cones, lava flows, lava domes, craters, and pyroclastic deposits of Quaternary age, which have compositions of tholeiitic basalt (or "transitional basalt"), alkalic basalt, hawaiite, mugearite, benmoreite, and trachyte (nomenclature from Cox and others, 1979) (figs. 4A, 5). The compositions of these Quaternary volcanic rocks are discussed in detail below, in the section entitled "Compositions and Eruptive Styles of Volcanic Rocks."

${ }^{1}$ U.S. Geological Survey.

${ }^{2}$ Saudi Geological Survey.
Older volcanic rocks (unrelated to volcanism at northern Harrat Rahat) have been mapped in the northernmost part of sheet 1. These include Quaternary-age (early Pleistocene) basalts (units Qbhk, Qbjs, and Qbra) erupted from the Harrat Kurama volcanic field (fig. 2), located east of Al-Madinah, and Tertiary-age basalts and hawaiites (units Tbja and Tbjj), which cap high-standing hills made up of metamorphosed Precambrian sedimentary, volcanic, and igneous rocks (unit p€), located west of Al-Madinah. Precambrian rocks form broad, mountainous regions that surround northern Harrat Rahat, but they also are present as isolated, scattered kipukas along the margins of the volcanic field. Surficial deposits include modern alluvium (unit al), which is restricted to modern drainage channels, and Quaternary alluvium, colluvium, loess, mud flat, and sabkha (Arabic for "salt flat") deposits (together, unit Qal), which are identified throughout northern Harrat Rahat and the surrounding area.

\section{Physiography and Access}

In contrast to the densely urbanized city of Al-Madinah, most of the mainly volcanic map area is sparsely populated and contains few man-made structures (sheet 1; see also, fig. 2). Farming communities and small towns lie in a valley along the volcanic field's western margin and also, locally, along its eastern margin, on the edge of a mud flat-filled valley. Volcanic rocks are exposed widely throughout the city of Al-Madinah, allowing ample opportunities to view them in roadcuts, parks, and excavations for new buildings. However, access to most of the city is restricted, and appropriate permissions are required prior to traveling to, or sampling within, these areas. Several major roadways run along the periphery of northern Harrat Rahat, and one road cuts through the volcanic field. The roads include (1) Highway 15, which runs north-south along the western margin of the map area, (2) Highway 60, which runs east-west across the northern part of the map area, (3) a well-maintained paved road that runs southeastward from Al-Madinah to Mahd Adh Thahab (fig. 2), crossing the crest of the volcanic field in the east-central part of the map area, (4) three ring roads that circle the densely populated areas of Al-Madinah, and (5) a well-maintained dirt road that runs east-west near the southern border of the map area. The Prince 


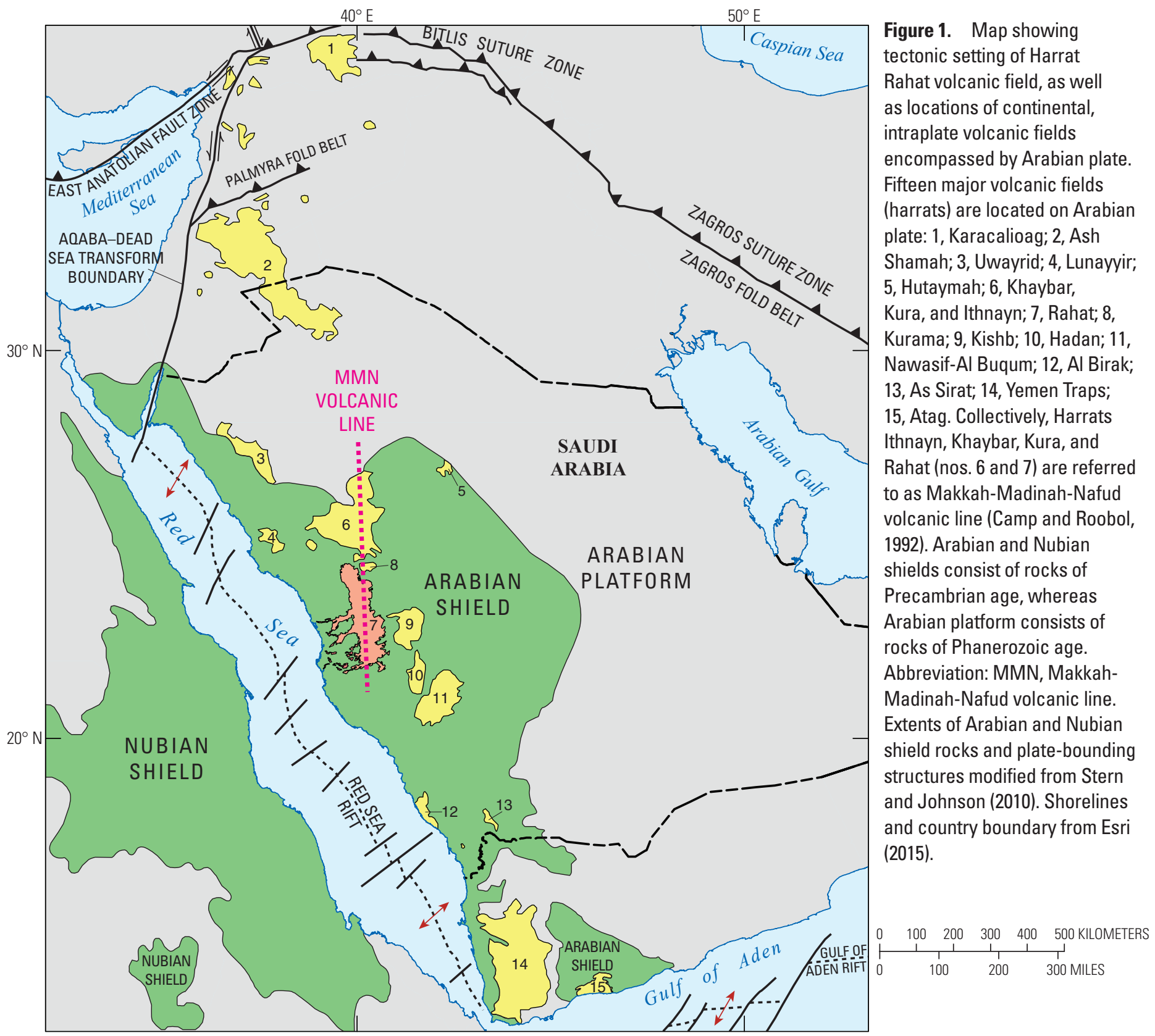

EXPLANATION

Harrat Rahat

Harrats

Precambrian shield rocks line
Tectonic plate boundaries

$\rightleftharpoons$ Transform fault - Arrows show direction of relative motion

_. Convergent margin-Sawteeth (on upper plate) show direction of convergence

- - - $\hat{\vee}$-. Divergent (rift) margin—Red arrows show direction of rifting
Mohammed Bin Abdulaziz International Airport lies in the northeast corner of the map area, and a high-speed railroad connecting Al-Madinah with Jeddah and Makkah runs along the western slope of the volcanic field. Mainly unpaved minor roads cross most remaining areas of northern Harrat Rahat, allowing straightforward access to the map area. The unpaved and, in most instances, poorly maintained nature of most roads within the central part of northern Harrat Rahat means that either helicopters or high-clearance vehicles that have 4-wheel drive are necessary to access the volcanic rocks of interest.

Designated hiking trails do not exist within northern Harrat Rahat. However, the unvegetated nature of northern Harrat Rahat and its surrounding areas, coupled with the generally level topography, make hiking to areas of interest relatively 


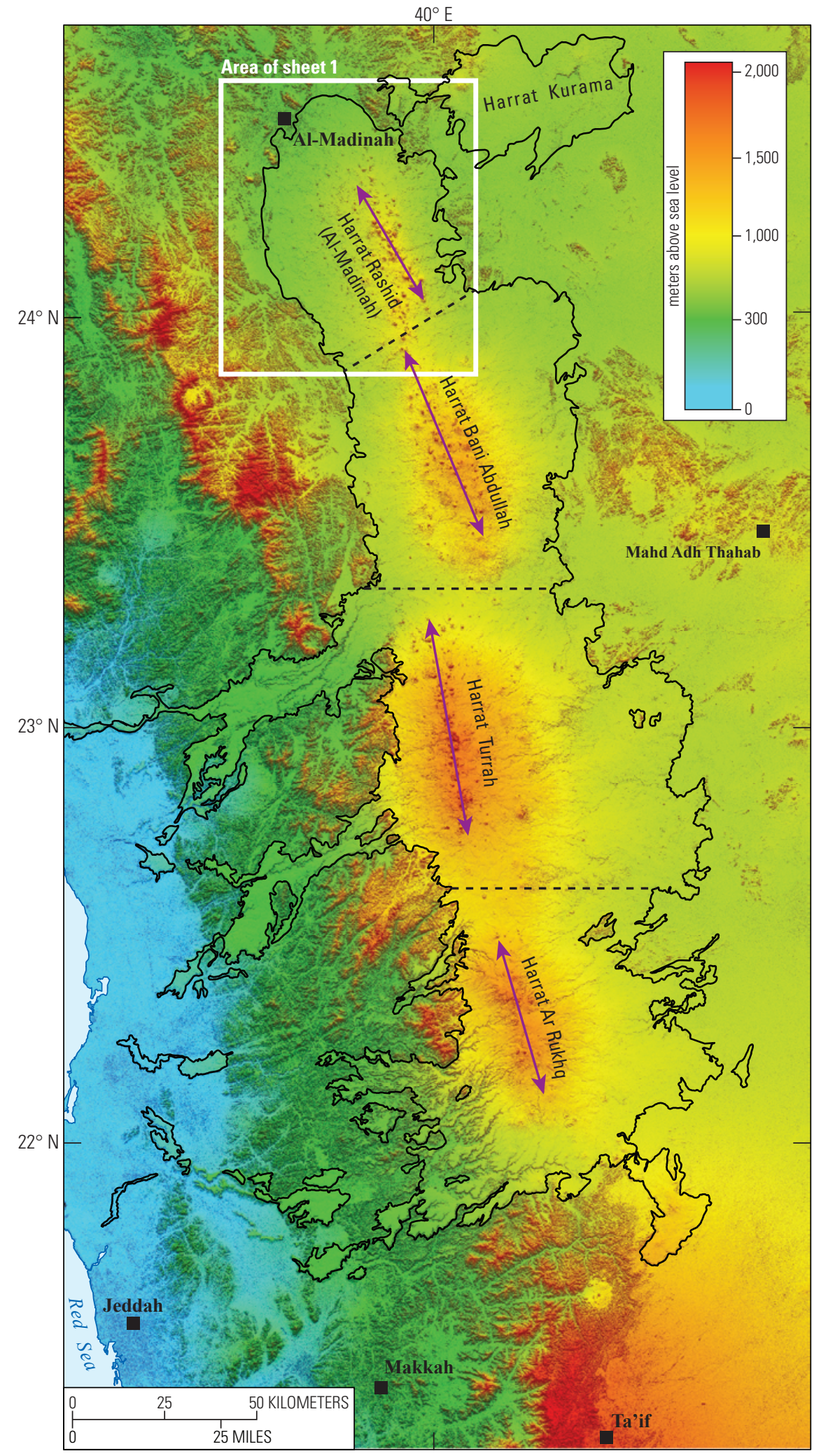

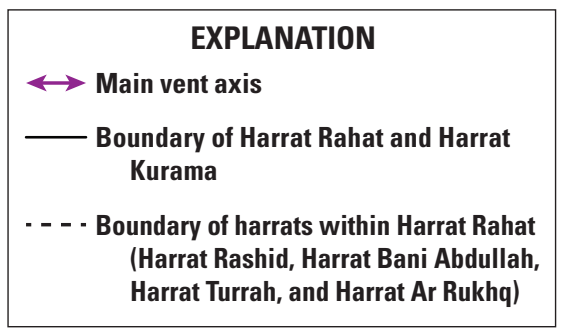

Figure 2. Colored shaded-relief map of Harrat Rahat volcanic field, which is composite of (listed from south to north) Harrat Ar Rukhq, Harrat Turrah, Harrat Bani Abdullah, and Harrat Rashid (also called Harrat Al-Madinah) volcanic fields, each having its own main vent axis. Although northernmost part of Harrat Rahat can be called either Harrat Rashid or Harrat Al-Madinah, we call it "northern Harrat Rahat" herein. White box shows area of sheet 1. Outlines of harrats from Camp and others (1987). Shaded-relief base map from 12-m-resolution TanDEM-X digital elevation model acquired from German Aerospace Center in 2017. Shorelines from Esri (2015); city locations digitized from Google Earth imagery in 2015. easy. Drainage channels that can reach more than $10 \mathrm{~m}$ deep cut into the landscape, through older lava flows and easily erodible pyroclastic deposits. Hiking on younger lava flows offers more of a challenge, as many of these retain the rubbly and glassy textures typical of 'a'à lavas.

The central part of the map area contains a north-northwesttrending concentration of scoria cones, lava domes, and craters that has been termed the main vent axis (fig. 5), which is also the topographic crest of the volcanic field and marks the locus of the most frequent eruptive output. A subsidiary and more diffuse vent axis lies 5 to $10 \mathrm{~km}$ west of the main vent axis, but other scoria cones are scattered throughout the map area (fig. 5). Eruptive units flowed both eastward and westward off the main vent axis, as well as northward from its northern tip. Many scoria cones 
Figure 3 (on sheet 4). Shaded-relief map of northern Harrat Rahat volcanic field, showing distribution of volcanic-rock units (grouped by eruptive stage) and other units shown on sheet 1. Map is divided into sections (yellow boxes), provided to help locate map units: yellow alphanumeric labels (section designators) are included in brackets in each map-unit description (see Description of Map Units, in pamphlet; see also, List of Map Units and column heads in Correlation of Map Units). Also shown are areas of 1:25,000-scale maps on sheets 2 and 3 . Shaded-relief base map from 12-m-resolution TanDEM-X digital elevation model acquired from German Aerospace Center in 2017. Roads and railroad modified from OpenStreetMap data in 2015. Figure is on sheet 4; caption included here for continuity.

Figure 4. Plots showing analyses of 661 volcanic rocks from northern Harrat Rahat volcanic field. $A, \mathrm{Na}_{2} \mathrm{O}+\mathrm{K}_{2} \mathrm{O}$ versus $\mathrm{SiO}_{2}$ contents (in weight percent), plotted on total alkali versus silica diagram of Cox and others (1979). Alkaline and subalkaline fields (delineated by dashed line) from Irvine and Baragar (1971). $B_{1} K_{2} O$ versus $\mathrm{SiO}_{2}$ contents (in weight percent), plotted on low-, medium-, and high-potassium (K) fields of Gill (1981).

\begin{tabular}{|lll|}
\hline \multicolumn{3}{|c|}{ EXPLANATION } \\
$\Delta$ Tholeiitic basalt & $\circ$ Mugearite \\
$\circ$ Alkalic basalt & $\circ$ Benmoreite \\
$\circ$ Hawaiite & $\circ$ Trachyte \\
\hline
\end{tabular}
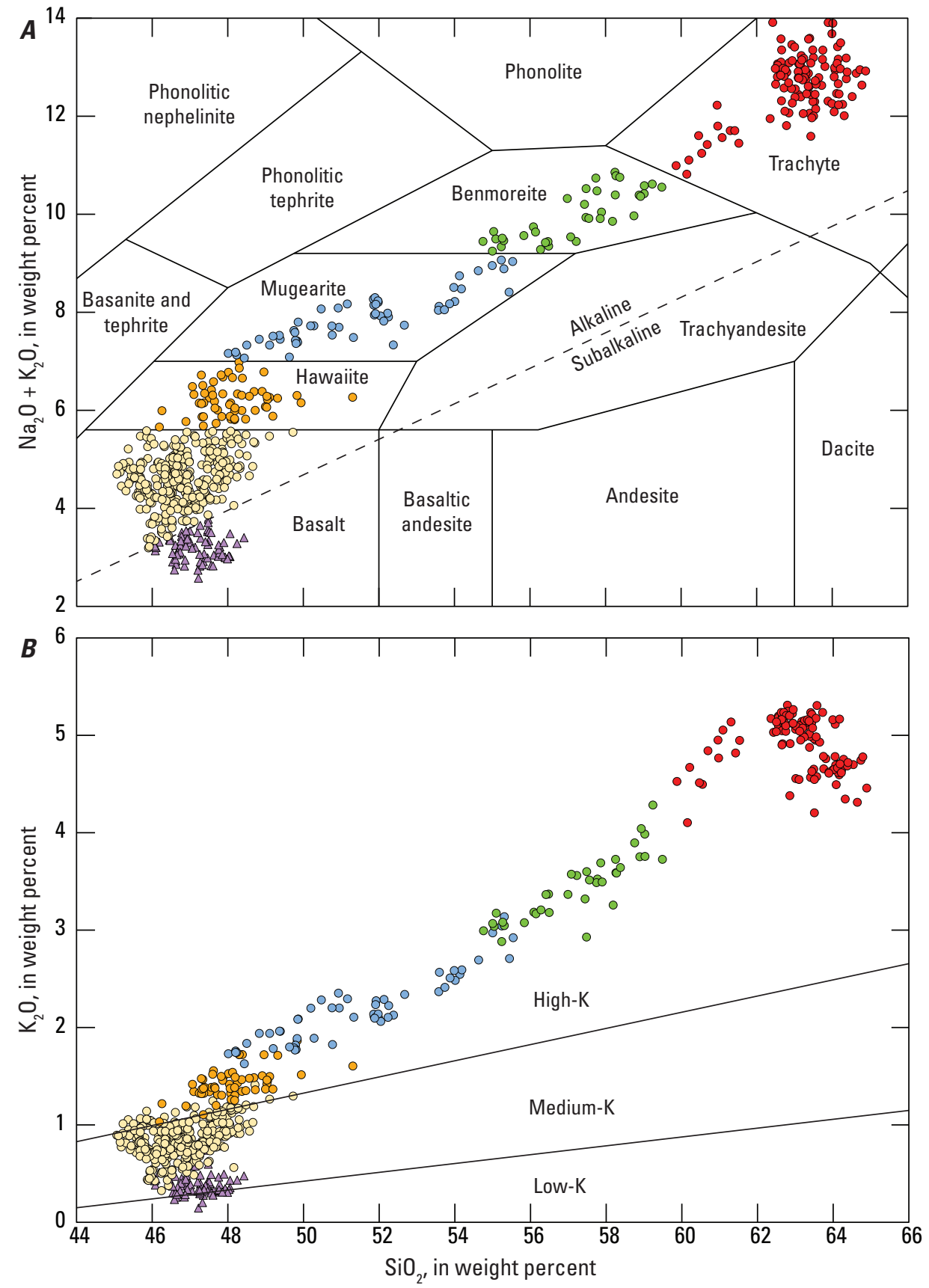

and lava domes rise more than $100 \mathrm{~m}$ above the main vent axis and its surrounding volcanic plain, reaching elevations of more than $1,300 \mathrm{~m}$ above sea level. By comparison, the surrounding volcanic plain, which slopes gently away from the main vent axis, has elevations of only 700 to $900 \mathrm{~m}$ above sea level.

Mapping was done during the late fall and winter months to avoid the extreme heat of summer and early fall, during which temperatures can reach well above $40{ }^{\circ} \mathrm{C}$; in contrast, temperatures in the late fall and winter tend to stay in the 10 to $20{ }^{\circ} \mathrm{C}$ range. However, unpredictable thunderstorms and flash floods can occur during any time of the year but are most common during the fall and winter months. 


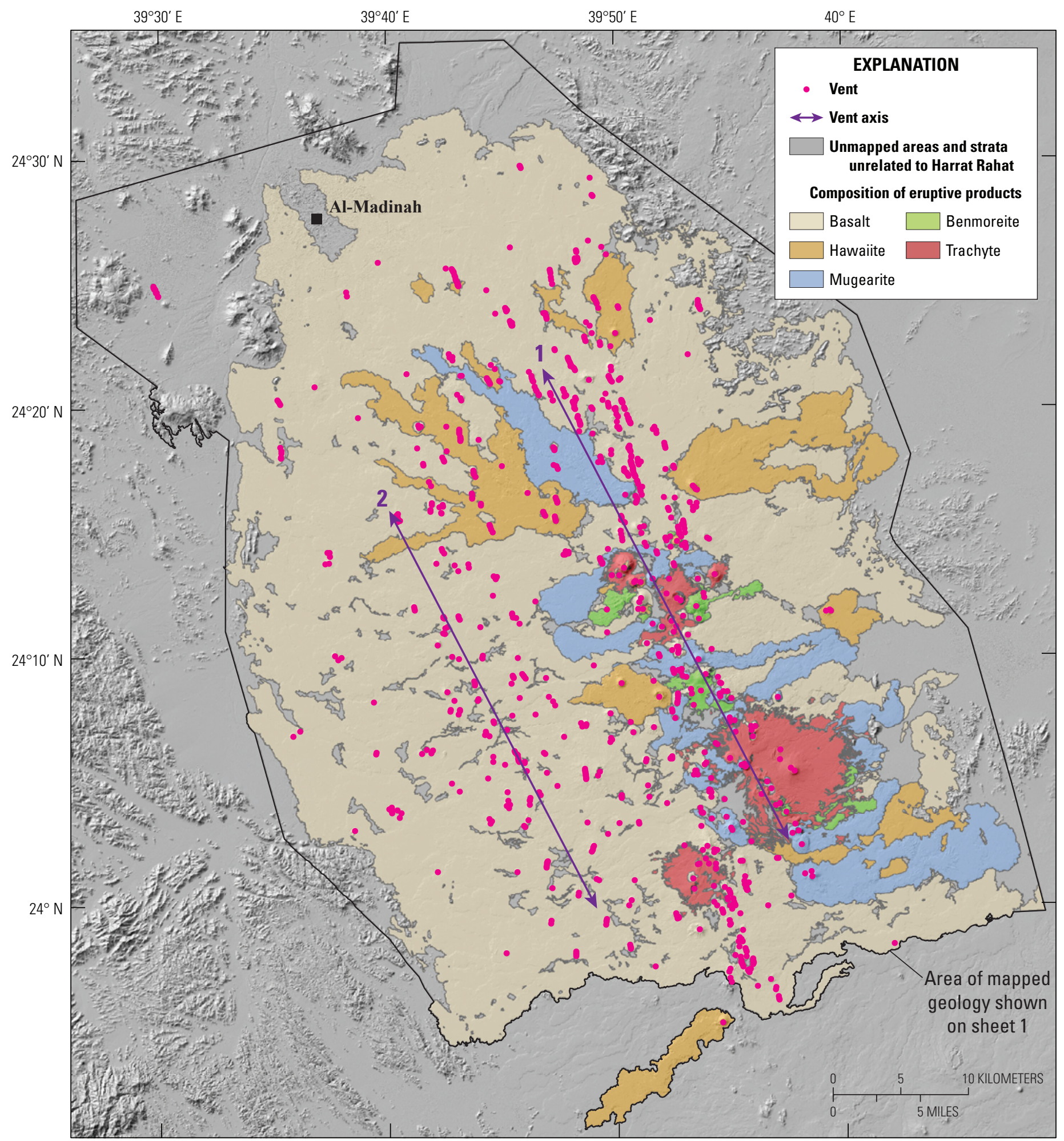

Figure 5. Shaded-relief map of northern Harrat Rahat volcanic field (about 3,340 $\mathrm{km}^{2}$; see sheet 1), showing compositions of eruptive products. Magenta dots indicate locations of vents (includes eruptive domes, craters, scoria cones, nonerupted cryptodomes, and nested and aligned craters and scoria cones from single eruptions). Purple arrows show approximate locations and trends of vent axes: (1) main vent axis, which encompasses eruptive vents for most of northern Harrat Rahat; (2) western subsidiary vent axis, which encompasses fewer and more diffuse eruptive vents. Compositional ranges of these rock types are discussed in detail in section entitled "Compositions and Eruptive Styles of Volcanic Rocks." Shaded-relief base map from 12-m-resolution TanDEM-X digital elevation model acquired from German Aerospace Center in 2017. City location digitized from Google Earth imagery in 2015. 


\section{Previous Work}

Reconnaissance mapping of Cenozoic volcanic fields of the Arabian plate, including Harrat Rahat, was undertaken by Coleman and others (1983). Harrat Rahat itself was mapped piecemeal in the 1980 s as a series of eight 1:250,000-scale map sheets (fig. 6) for the Saudi Arabian Deputy Ministry of Mineral Resources; these include the (1) Al Madinah (Pellaton, 1981), (2) Al Hamra (Clark, 1981), (3) Umm Al Birak (Camp, 1986), (4) Mahd Adh Dhahab (Kemp and others, 1982), (5) Rabigh (Ramsay, 1986), (6) Al Muwayh (Sahl and Smith, 1986), (7) Makkah (Moore and Al-Rehaili, 1989), and (8) Turabah (Ziab and Ramsay, 1984) maps. An unpublished Ph.D. dissertation by Moufti (1985) presents much of the detail of the more evolved, silicic volcanic rocks within northern Harrat Rahat. Camp and Roobol (1991) undertook new fieldwork, sample collection and analyses, and interpretation of petrographic, geochemical, and geochronological data to create a 1:250,000-scale map that covers all of Harrat Rahat (fig. 6). Pellaton (1981), Camp (1984), and Stoeser and Camp (1985) investigated the Precambrian rocks surrounding Harrat Rahat, which make up the Arabian shield; in addition, Stern and Johnson (2010) published a comprehensive geological review. Johnson (2006) published the most up-to-date map of Precambrian terranes in Saudi Arabia.

Camp and Roobol $(1989,1991)$ compiled 15 potassiumargon (K-Ar) isotopic ages for Harrat Rahat from Pellaton (1981) and Coleman and others (1983), as well as presented 10 new
$\mathrm{K}$-Ar ages; together, these $25 \mathrm{~K}$-Ar ages outline the timing of volcanic activity. Although 12 of the 25 ages were assessed to be of questionable accuracy, the 13 acceptable ages were used to divide late Cenozoic volcanic stratigraphy of Harrat Rahat into the Shawahit (10-2.5 Ma), Hammah (2.5-1.7 Ma), and Madinah (1.7 Ma to the present) basalts; the Madinah basalts are almost exclusively confined to northern Harrat Rahat. In addition, Camp and Roobol $(1989,1991)$ used eight of the acceptable ages to further subdivide the Madinah basalts into seven Quaternary subunits (their subunits " $\mathrm{Qm}{ }_{1}$ " as the oldest through " $\mathrm{Qm}{ }_{7}$ " as the youngest). However, the scarcity of isotopic ages throughout northern Harrat Rahat forced Camp and Roobol $(1989,1991)$ to resort to using remote sensing, combined with geomorphic and archeological criteria, to interpret the ages of most of the Quaternary volcanic rocks. Therefore, assignment of most units to subunits " $\mathrm{Qm}_{1}$ " through " $\mathrm{Qm} \mathrm{m}_{7}$ " was based on the inferred degree of erosion, as well as the size and abundance of loess-filled depressions present across lava-flow surfaces; assignment to the two youngest subunits " $Q \mathrm{~m}_{6}$ " and " $\mathrm{Qm}{ }_{7}$ " also relied on inferences from archeological and historical evidence, respectively.

Moufti and others (2013) added $25{ }^{40} \mathrm{Ar} /{ }^{39} \mathrm{Ar}$ isotopic ages from northern Harrat Rahat and redefined the Madinah basalts as lasting from 10.31 Ma to the present. Both Camp and Roobol's $(1989,1991)$ and Moufti and others' (2013) ages commonly contradict the exposed stratigraphic superposition of contiguous units. Additionally, most research in Harrat Rahat has revolved around the youngest eruption in 1256 C.E. (Al-Samhoody, 1486;

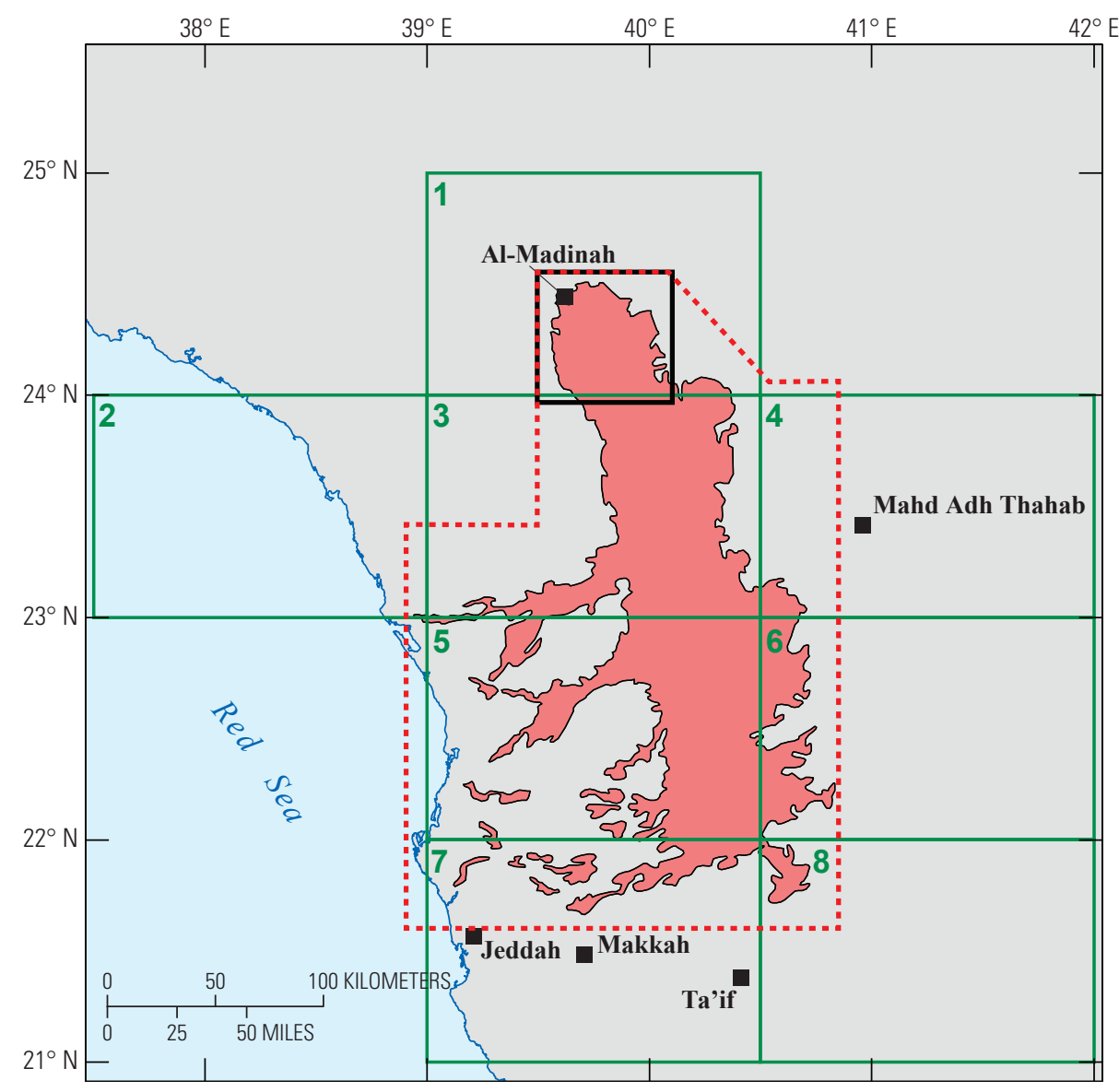

Figure 6. Map of Harrat Rahat volcanic field (red shading), showing area of sheet 1 (black box) in relation to previously published geologic maps. Dashed red line shows area of geologic map of Harrat Rahat by Camp and Roobol (1991). Green boxes and numbers show other regional-scale $(1: 250,000)$ geologic maps: 1, Al Madinah (Pellaton, 1981); 2, Al Hamra (Clark, 1981); 3, Umm Al Birak (Camp, 1986); 4, Mahd Adh Dhahab (Kemp and others, 1982); 5 , Rabigh (Ramsay, 1986); 6, Al Muwayh (Sahl and Smith, 1986); 7, Makkah (Moore and Al-Rehaili, 1989); 8, Turabah (Ziab and Ramsay, 1984). 
Camp and others, 1987; Kawabata and others, 2015; Kereszturi and others, 2016; Murcia and others, 2017; Dietterich and others, 2018), which vented only about $20 \mathrm{~km}$ from the center of Al-Madinah and whose lava flows reached less than $8 \mathrm{~km}$ from the city center. Other young-appearing lava flows that are proximal to Al-Madinah have had only a few detailed investigations that provided ages, geochemistry, and petrographic descriptions (for example, Murcia and others, 2015, 2017; Dietterich and others, 2018; Downs and others, 2018). The overall scarcity of isotopic ages throughout northern Harrat Rahat, as well as the inconsistencies between published isotopic ages and stratigraphic superposition, highlighted the need for renewed mapping and geochronology in the northern Harrat Rahat volcanic field.

Our geologic mapping, ages, and geochemistry from northern Harrat Rahat provide the context for volcanic- and seismic-hazard assessments for the city of Al-Madinah, and they are critical for (1) understanding the spatial, temporal, and compositional evolution of the northern Harrat Rahat volcanic field, (2) determining the time scales of magmatic processes in the mantle and crust, and (3) modeling future hazard-related impacts to the area that are based on the timing and varied styles of volcanism in the region.

As part of this project, additional local-scale maps that integrate petrography, geochemistry, and geochronology have been published (Dietterich and others, 2018; Downs and others, 2018; Stelten and others, 2018). Downs and others (2018) presented a detailed geologic map of Pleistocene to Holocene mafic volcanism in Al-Madinah and its immediately surrounding areas; its geochemical data indicate that each eruption vented a compositionally restricted magma batch, whereas its paleomagnetic data and ${ }^{40} \mathrm{Ar} /{ }^{39} \mathrm{Ar}$ ages demonstrate that some eruptions were temporally and (or) spatially clustered, with most units close to and within Al-Madinah having erupted between 400 and $340 \mathrm{ka}$ and between 180 and $100 \mathrm{ka}$. Dietterich and others (2018) interrogated mafic eruptive styles by quantifying eruption magnitudes and dynamics (that is, flow rheology and effusion rates), as well as the emplacement durations of the 1256 C.E. eruption (unit bla) and the "Five Fingers" lava flows (units bcef, bnof, and bsof). Their research yielded effusion rates on the order of 40 to 100 cubic meters per second $\left(\mathrm{m}^{3} / \mathrm{s}\right)$, giving emplacement intervals that range from 1 to 13 weeks; this result conforms to the observed 52 days (approximately 7.5 weeks) of the 1256 C.E. eruption (unit bla). Stelten and others (2018) investigated the lengths of time necessary to produce, segregate, and erupt intermediate-composition (mugearite and benmoreite) and more evolved (trachyte) magmas following intrusions and eruptions of mantle-derived basalts at northern Harrat Rahat. Mapped field relations demonstrate that, for the northern part of the trachyte deposits in Harrat Rahat, intermediatecomposition (mugearite and benmoreite) eruptions followed the basaltic eruptions by approximately 2 k.y.; these intermediatecomposition eruptions, in turn, were followed by the eruption of trachytes between $22.5 \pm 3.2$ and $6.6 \pm 4.3 \mathrm{k} . \mathrm{y}$.

\section{Methods}

Fieldwork was conducted for a few weeks each year in $2014,2015,2016$, and 2017, in the late fall or winter months when moderate temperatures allowed for extended time in the field for mapping and sample collection. The lack of vegetation across the arid volcanic terrain of northern Harrat Rahat allowed much of the field mapping to be compiled digitally in a geographic information system (GIS), using high-resolution light detection and ranging (lidar), digital elevation models (DEMs), shaded-relief maps, and satellite photogrammetric base layers. The nature and accuracy of contacts, along with the identities of volcanic products, were determined in the field; the mapped units then were characterized, correlated, and distinguished by thin-section-petrographic, geochemical, paleomagnetic, and geochronologic studies. Downs and others (2018) and Stelten and others (2018) reported analytical methods for the geochemistry, paleomagnetism, and geochronology data collected. Some geochemical, paleomagnetic, and geochronologic results are available in Dietterich and others (2018), Downs and others (2018), and Stelten and others (2018); however, the entire geochemistry dataset is available online (Downs, 2019).

In this report, the map units (and their eruptive stages) are listed alphabetically by map-unit label in table 1 . Their ${ }^{40} \mathrm{Ar} /{ }^{39} \mathrm{Ar}$ isotopic ages are provided in table 2 ; their ${ }^{36} \mathrm{Cl}$ cosmogenic surface-exposure ages, in table 3; and their paleomagnetic data, in table 4.

Our goals of mapping were to study the Quaternary basalt to trachyte eruptive products from northern Harrat Rahat in sufficient detail for quantitative assessments of hazards of eruptive and magmatic processes. We mapped the older mafic lava flows (units Qbhk, Qbjs, Qbra, Tbja, and Tbjj) in the northernmost part of the map area, as well as the Precambrian rocks (unit p€) that surround the map area, but these were not investigated in detail, nor were the Precambrian rocks divided into separate map units (see Pellaton, 1981, for a 1:250,000-scale geologic map of the Precambrian rocks around Al-Madinah and northern Harrat Rahat).

As mentioned previously, Camp and Roobol (1989, 1991) divided the Harrat Rahat volcanic rocks into the Shawahit (10-2.5 Ma), Hammah (2.5-1.7 Ma), and Madinah (1.7 Ma to the present) basalts, and they further subdivided the Madinah basalts into seven subunits ("Qm," through "Qm,"); this division was propagated and also further revised in the literature by Moufti and others (2013). However, we have assigned each of our mapped volcanic units a name that is based on topographic landforms, city districts, watersheds, or other relevant geographic features. Previously assigned names for the geologic units, although scarce (for example, Moufti, 1985; Murcia and others, 2015; Downs and others, 2018), have been retained where appropriate. In the absence of a precedent, names were assigned with preference for that unit's source vent type (that is, scoria cone, crater, or lava dome). However, many units lack known source vents, or they have vents whose names could not be discovered; such units were named for the prominent watersheds, mountains, city districts, or man-made structures that they encompass or to which they are within close proximity. Quaternary volcanic units related to volcanism within northern Harrat Rahat are assigned to 12 successive eruptive stages that supplant the former "Qm," to "Qm $\mathrm{m}_{7}$ " subunits. Older volcanic units that are unrelated to Harrat Rahat volcanism (units Qbhk, Qbjs, Qbra, Tbja, and Tbjj) are labeled for the geologic time period $(\mathrm{Q}$, Quaternary; T, Tertiary), the composition (b, basalt), and the geographic location. 


\section{Geologic and Tectonic Setting}

The Arabian Peninsula is on the Arabian plate, which is bounded on the northeast by the Bitlis-Zagros suture zone, on the west and south by the Red Sea and Gulf of Aden spreading ridges, respectively, and on the northwest by the Aqaba-Dead Sea and East Anatolian transform boundaries. The eastern part of the Arabian plate is covered by Phanerozoic platform sediments, whereas the western part is the Precambrian Arabian shield (fig. 1). Rocks of the Arabian shield consists mostly of accreted island-arc terranes formed during the Neoproterozoic between 850 and $630 \mathrm{Ma}$ (Camp, 1984; Stoeser and Camp, 1985; Stern, 1994; Johnson, 2006; Stern and Johnson, 2010). The Arabian plate separated from the African plate sometime between 30 and $25 \mathrm{Ma}$ as a result of extension across the Red Sea and Gulf of Aden rifts (figs. 1, 7). Present-day extension across the Red Sea rift occurs at 16 to 20 millimeters per year $(\mathrm{mm} / \mathrm{yr})$, and across the Gulf of Aden rift, at as much as 20 $\mathrm{mm} / \mathrm{yr}$, which has resulted in the counterclockwise rotation and northward drift of the Arabian plate at 20 to $30 \mathrm{~mm} / \mathrm{yr}$ (fig. 7; see also, McGuire and Bohannon, 1989; Bellahsen and others, 2003; Bosworth and others, 2005; Stern and Johnson, 2010). This extension and rotation results in continental collision with the Eurasian plate along the Bitlis-Zagros suture zone and also left-lateral movement along the Aqaba-Dead Sea and East Anatolian transform boundaries (Bahroudi and Talbot, 2004; Mohsen and others, 2005; Kaviani and others, 2007).

Late Cenozoic volcanism is manifested throughout the western part of the Arabian plate (fig. 1) as localized intrusive and extrusive suites of basalt to minor amounts of more evolved, silicic rocks (see, for example, Coleman and others, 1983; Camp and Roobol, 1989, 1991; Camp and others, 1991, 1992; Duncan and Al-Amri, 2013; Duncan and others, 2016). These volcanic rocks are concentrated into 15 large continental, intraplate volcanic fields, as well as many smaller, scattered volcanic fields, in Yemen, Saudi Arabia, Jordan, Syria, and southern Turkey (fig. 1). In total, these volcanic fields cover an area of around $180,000 \mathrm{~km}^{2}$, and they stretch over 3,000 $\mathrm{km}$ north-south, constituting one of the largest alkalic-volcanic provinces on Earth (Coleman and others, 1983). Ambraseys and others (2005) and Siebert and others (2010) compiled historical records that document at least 21 eruptions that have occurred throughout the Arabian plate over the past 1,500 yr; the youngest of these occurred in 1937 C.E. within the Yemen Traps (volcanic field no. 14, on fig. 1).

Eruptive products younger than $10 \mathrm{Ma}$ on the Arabian plate have been interpreted to be related to the Afar plume, situated at the triple junction of the Red Sea, Gulf of Aden, and East African rift systems (fig. 7), whereas volcanic fields older than $10 \mathrm{Ma}$ are thought to be related to the initiation of Red Sea rifting (Almond, 1986). The expected northward migration of the Afar plume beneath the Arabian plate corresponds to the north-south trend of aligned volcanic fields, as well as to the similarly aligned, en echelon vent axes within individual volcanic fields (Camp and Roobol, 1992; Mellors and others, 1999). The mechanism of magma genesis remains cryptic, as direct decompression melting of Afar plume material is considered unlikely (Konrad and others, 2016). Regardless, the Afar plume is implicated in producing the regional Afro-Arabian dome (a high-standing region in the western Arabian Peninsula) and its resulting extensional faulting and fracturing, creating pathways for dikes to intrude the crust and for magma to ascend to the surface during eruptions. Camp and Roobol (1992) proposed that volcanic activity is concentrated along the MakkahMadinah-Nafud volcanic line (fig. 1), which is a north-south alignment of volcanic fields represented by, from south to north, Harrat Rahat, Harrat Khaybar, Harrat Kura, and Harrat Ithnayn (fig. 1) in Saudi Arabia. These volcanic fields are inferred to overlie northward flow of the Afar plume.

Continental crust beneath Harrat Rahat is approximately $40 \mathrm{~km}$ thick (Mooney and others, 1985). The upper crust around northern Harrat Rahat, which was mapped by Pellaton (1981), consists of mainly sandstone and graywacke of the Urafi Formation and also broadly andesitic rocks of the Qidirah Formation, both variably deformed and nonmetamorphosed to lightly metamorphosed and cut by granitic plutons and minor gabbros. The lower crust is interpreted to contain rocks that were metamorphosed to granulite facies (McGuire and Bohannon, 1989; Nasir and Safarjalani, 2000; Al-Mishwat and Nasir, 2004). The lithospheric mantle is divided into an upper layer of spinel peridotite, which transitions into garnet peridotite at about $60 \mathrm{~km}$ depth (Kuo and Essene, 1986; Al-Mishwat and Nasir, 2004). The lithosphere-to-asthenosphere transition has been imaged geophysically at 60 to $90 \mathrm{~km}$ deep beneath the Arabian volcanic fields but may deepen eastward to more than $150 \mathrm{~km}$ beneath the Arabian platform (Yao and others, 2017). Compositions of primitive basaltic magmas in the Harrat Rahat region have been interpreted as having been generated from partial melting of garnet peridotite within the asthenosphere at 2 to $3 \mathrm{GPa}$ (Al-Mishwat and Nasir, 2004; Moufti and others, 2012; Murcia and others, 2017). Mechanisms of melt generation may include (1) decompression related to rifting across the Red Sea and left-lateral movement along the Aqaba-Dead Sea transform boundary (Stein and Hofmann, 1992; Bosworth and others, 2005), (2) temperature increases from upwelling asthenosphere and thermal erosion of the lithosphere related to the Afar plume (Camp and Roobol, 1992), or (3) melting of a fossil plume head (Stein and Hofmann, 1992).

\section{Harrat Rahat Volcanic Field}

Harrat Rahat, the largest volcanic field within Saudi Arabia, is a composite of four smaller volcanic fields that have coalesced (Camp and Roobol, 1989): from south to north, (1) Harrat Ar Rukhq, (2) Harrat Turrah, (3) Harrat Bani Abdullah, and (4) Harrat Rashid (fig. 2). The map area on sheet 1 includes Harrat Rashid, which also is sometimes referred to as Harrat Al-Madinah (Moufti, 1985; Moufti and others, 2013), and the northwestern part of Harrat Bani Abdullah. Harrat Rahat extends over $300 \mathrm{~km}$ north-south and 50 to $75 \mathrm{~km}$ east-west, but a few lava flows reach more than $100 \mathrm{~km}$ from the crest of the volcanic field. Harrat Rahat covers an area of approximately $20,000 \mathrm{~km}^{2}$, has a volume of approximately $2,000 \mathrm{~km}^{3}$, and encompasses more than 900 volcanic vents (Coleman and others, 1983; Camp and Roobol, 1989, 1991; Runge and others, 2014). Geochronology indicates 


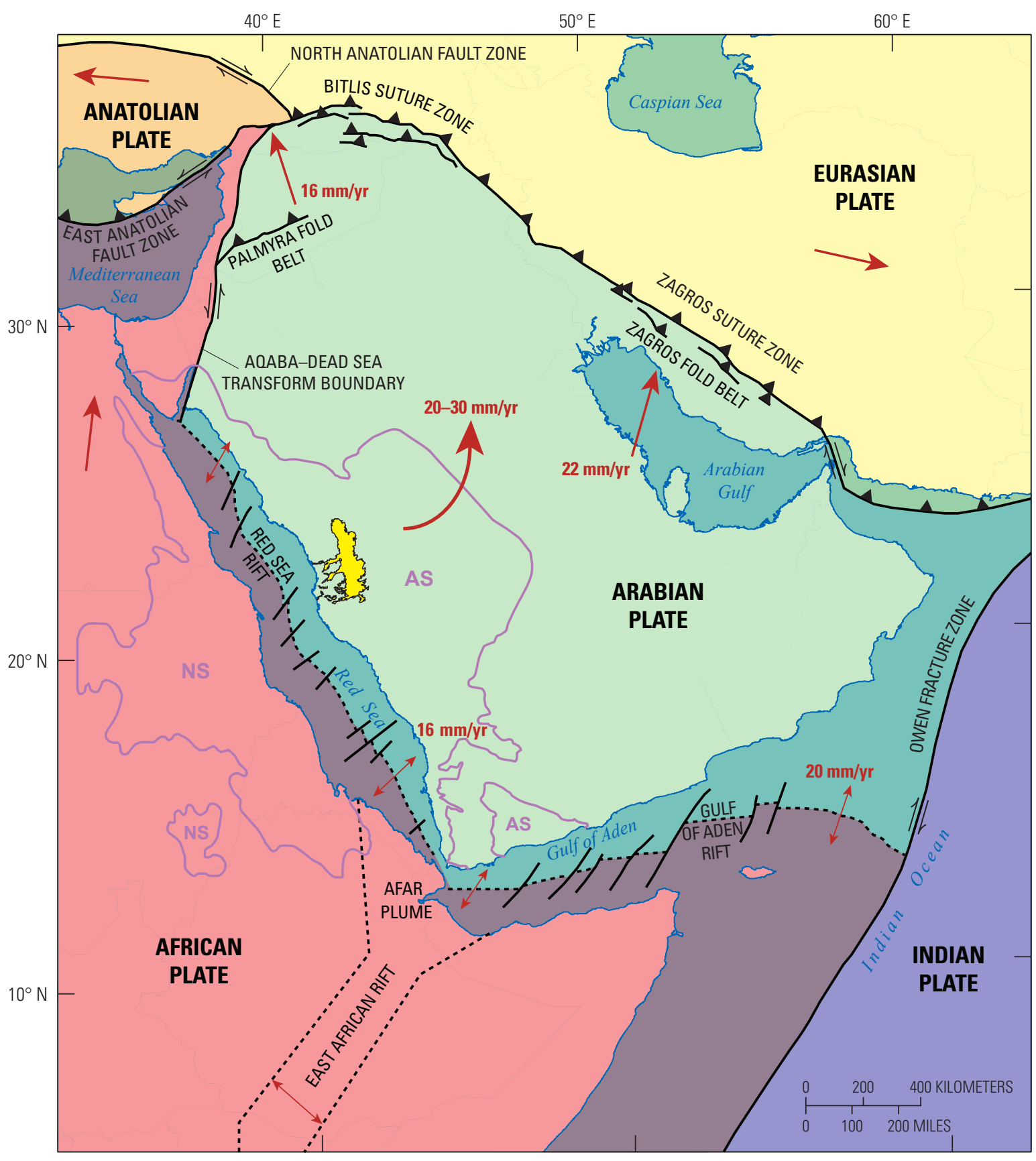

\section{EXPLANATION}

Precambrian shield rocks of Nubian shield (NS) and Arabian shield (AS)

\section{Harrat Rahat}

Tectonic plates (darker shades indicate land is covered by water)

African plate

Anatolian plate

Arabian plate

Eurasian plate

Indian plate (entire plate is covered by water)
Tectonic plate boundaries

$\rightleftharpoons$ Transform fault-Arrows show direction of relative motion

ـ Convergent margin-Sawteeth show direction of convergence

. - $\$$-. Divergent rift margin-Red arrows show direction of rifting. Rates of divergence (in millimeters per year) are given where known

\section{- ${ }^{-\cdot}$ East African rift-Red arrows show direction of rifting}

Direction of plate motion-For Arabian plate, rates are given in millimeters per year

Figure 7. Map showing tectonic setting of Arabian plate (green shading). Bounding structures, as well as relative rates and directions of plate motion, from Stern and Johnson (2010). Arabian shield (AS) rocks on Arabian plate have rifted away from Nubian shield (NS) rocks on African plate (reddish-orange shading) across Red Sea rift. Additionally, extension across both Gulf of Aden and Red Sea has resulted in counterclockwise rotation of Arabian plate, as well as its northward drift by 20 to $30 \mathrm{~mm} / \mathrm{yr}$. Location of Harrat Rahat is shown on Arabian plate for geographic context. 
that the oldest exposed volcanic rocks are at least $10 \mathrm{Ma}$ (Camp and Roobol, 1989, 1991) and that the most recent eruption (unit bla) was in 1256 C.E. (Al-Samhoody, 1486).

Harrat Rahat lies just east of and below the crest of rugged mountains that consist of Precambrian rocks of the Arabian shield. These mountains form a prominent escarpment that faces west towards the Red Sea coastal plain. Uplift of these mountains predated Harrat Rahat volcanism, as is shown by the large early Pleistocene lava flows that descend westward and southwestward, through gaps in the crest of the mountains, continuously to the Red Sea coastal plain (Camp and Roobol, 1991). Erosional remnants of Tertiary volcanic rocks (units Tbja and Tbjj) near Al-Madinah are 200 to $350 \mathrm{~m}$ higher than the Quaternary volcanic field, and they are interpreted to lie west of an unexposed, broadly north-striking, down-to-the-east normal fault system that may form the western boundary of the basin that hosts Al-Madinah and northern Harrat Rahat. Clearer evidence for basin-bounding faults is given by the presence of early Pleistocene lava flows (unit Qbra) immediately north of Harrat Rahat that are cut by north-northwest-striking normal faults having 10 to $20 \mathrm{~m}$ of displacement. However, only one fault within the map area has been definitively identified as having cut northern Harrat Rahat volcanic rocks; this fault accommodates $10 \mathrm{~m}$ of displacement of the lava flows of unit besa (eruptive stage 6), whose precise age is unknown but is stratigraphically constrained to be between the ages of units bsa $(288.8 \pm 19.6 \mathrm{ka})$ and $\mathrm{mmu}(219.6 \pm 4.0 \mathrm{ka})$. Faulting is inferred to have occurred approximately $3 \mathrm{~km}$ farther south, where it has displaced units bd3 (307.7 $\pm 4.6 \mathrm{ka}), \mathrm{mz} 2(195.9 \pm 1.3 \mathrm{ka})$, and tg4 $(84.3 \pm 1.6 \mathrm{ka})$ to create a 1 -km-long by 150 -m-wide graben; however, the poorly consolidated character of the capping unit (tg4) makes interpreting this potential graben difficult.

Both north and south of the fissure vent for unit bsof are ground cracks in units bag $(220.3 \pm 8.3 \mathrm{ka})$, bam4 (eruptive stage $6)$, bni (402.5 $\pm 15.4 \mathrm{ka})$, and bsi (151.9 $\pm 9.9 \mathrm{ka})$. These ground cracks are present in a north-northwest-trending, en echelon pattern along strike with the 2.9-km-long fissure vent of unit bsof, which erupted at $24.4 \pm 1.3 \mathrm{ka}$. The ground cracks have sharp edges, are minimally infilled by sediments (other than talus shed from walls of the cracks), and have not been incised by drainage systems, indicating that they are young features. We interpret these ground cracks to be fissures that opened during eruption of unit bsof, and they mark the near-surface expression of shallow dike intrusions. No apparent dip-slip or strike-slip movement is evident on these ground cracks, and so they have not been mapped as faults.

\section{Compositions and Eruptive Styles of Volcanic Rocks}

Eruptive products within northern Harrat Rahat encompass compositions that range from tholeiitic and alkalic basalt to hawaiite, mugearite, benmoreite, and trachyte (fig. $4 A$ ). These compositions, which are best represented by their $\mathrm{K}_{2} \mathrm{O}$ versus $\mathrm{SiO}_{2}$ contents (in weight percent) (fig. $4 \mathrm{~B}$ ), are determined herein (661 samples analyzed) to be tholeiitic basalt $\left(46.0-48.5 \% \mathrm{SiO}_{2}\right.$; $\left.0.1-0.8 \% \mathrm{~K}_{2} \mathrm{O}\right)$, alkalic basalt $\left(45.0-50.0 \% \mathrm{SiO}_{2} ; 0.3-1.5 \%\right.$
$\left.\mathrm{K}_{2} \mathrm{O}\right)$, hawaiite $\left(46.0-51.5 \% \mathrm{SiO}_{2} ; 1.0-1.9 \% \mathrm{~K}_{2} \mathrm{O}\right)$, mugearite (48.0-56.0\% $\left.\mathrm{SiO}_{2} ; 1.6-3.2 \% \mathrm{~K}_{2} \mathrm{O}\right)$, benmoreite $(54.5-60.0 \%$ $\left.\mathrm{SiO}_{2} ; 2.8-4.3 \% \mathrm{~K}_{2} \mathrm{O}\right)$, and trachyte $\left(59.5-65.0 \% \mathrm{SiO}_{2} ; 4.1-5.4 \%\right.$ $\left.\mathrm{K}_{2} \mathrm{O}\right)$. Camp and Roobol (1989) estimated that the entire eruptive volume of Harrat Rahat is composed of 83 percent tholeiitic and alkalic basalt (equivalent to, and termed by them as, "olivine transitional basalt" and "alkali olivine basalt," respectively), 13 percent hawaiite, and 4 percent more evolved compositions of mugearite, benmoreite, and trachyte. Most lavas that have mugearite, benmoreite, and trachyte compositions are restricted to northern Harrat Rahat (see sheets 1,3). Areal percentages of (exposed) mapped rocks that are related to northern Harrat Rahat volcanic activity are 76 percent tholeiitic and alkalic basalts, 10 percent hawaiite, 9 percent mugearite, and 5 percent benmoreite and trachyte. In the early Pliocene, eruptions of tholeiitic and minor alkalic basalts dominated volcanic activity; later in the Pliocene, however, alkalic basalts overtook tholeiitic basalts as the predominant volcanic composition being erupted, and, since the Pleistocene, eruptions of alkalic basalt have been contemporaneous with those of minor volumes of hawaiite, mugearite, benmoreite, and trachyte (Camp and Roobol, 1989).

Eruptions within northern Harrat Rahat created many prominent landforms, the most obvious of which are the numerous scoria cones and the (less abundant) shield volcanoes. Scoria cones generally are steep sided and rise more than $100 \mathrm{~m}$ above the surrounding lava flows, but some only reach a few tens of meters in height. Scoria cones commonly have either nested craters or north- to northwest-aligned clusters of craters and (or) cones (fig. 5). These clusters are the result of fissure eruptions (see fig. 8, on sheet 4 , for a photograph of the fissure vent that erupted unit bcef); the best studied fissure, which is more than $2 \mathrm{~km}$ long, formed seven north-northwest-aligned scoria cones during the 1256 C.E. eruption of unit bla. Many scoria cones are partly collapsed where lava breached and drained from a central crater. During some breaches, material from scoria cones became rafted and may have been carried more than $1 \mathrm{~km}$ from their source. Scoria cones generally are composed of vesicular-vitric bombs, lapilli, agglutinated spatter ramparts, and, locally, spindle bombs. Scoria cones older than 100 ka commonly are heavily eroded and have a strongly oxidized, reddish-brown patina, whereas younger scoria cones retain their black appearance. On the other hand, the less abundant shield volcanoes (for example, units bfa, bgh, bh89, and bhu) have gentle slopes of only a few degrees and can be as much as $4 \mathrm{~km}$ in diameter, and they usually have a central crater whose diameter can exceed $1 \mathrm{~km}$. Lava flows associated with these shield volcanoes, which generally are between 10 and $15 \mathrm{~m}$ thick, produce ' $\mathrm{a}$ 'ā and pāhoehoe flow morphologies, as well as some that are transitional between the two.

Lavas that have basalt, hawaiite, and mugearite compositions mainly erupted in Hawaiian and Strombolian styles, which resulted in scoria cones and spatter ramparts. Basaltic lava flows can be as much as $26 \mathrm{~km}$ long, although flows 10 to $15 \mathrm{~km}$ long are more common. Mugearite flows tend to be shorter $(<10 \mathrm{~km})$, broader, and thicker, and their surfaces can be decorated with numerous hornitos or arcuate pressure ridges. Some magmas interacted with shallow groundwater, mainly along the high crest of the volcanic field, causing phreatomagmatic eruptions that excavated maar craters (for example, at Gura 1 [unit bg1]) and deposited 
fine-grained palagonitic tephras within scoria cones (for example, unit bya). Deposits of air-fall tephra are rare (other than the proximal scoria in cones); their lack of preservation is likely the result of their small volumes, coupled with the dry, vegetation-free environment in which eolian and fluvial processes quickly remobilize fine-grained unconsolidated material. The only well-preserved air-fall-tephra deposit was created by fire fountaining during the 1256 C.E. eruption of unit bla, and it is only preserved within 5 $\mathrm{km}$ from the vent (Kawabata and others, 2015).

Volcanoes that have more silicic compositions (for example, benmoreite and trachyte) commonly erupted in a Peléan manner, developing lava domes and spines that periodically collapsed and generated small-volume, juvenile-pumice- and lithic-rich pyroclastic deposits (figs. 9, 10, on sheet 4); however, sub-Plinian eruptions are inferred to have occurred as well, resulting in craters and moderately pumiceous pyroclastic deposits (figs. 10, 11, on sheet 4), which are preserved as much as $9 \mathrm{~km}$ from their sources (for example, Moufti, 1985; Camp and Roobol, 1989; Stelten and others, 2018). Many of the trachyte pyroclastic deposits are young, are in direct stratigraphic contact with each other, and have broadly similar appearances in the field. Additionally, these pyroclastic deposits are weakly consolidated and, hence, are easily erodible; this results in them having a ragged appearance (on sheets 1,3) along their margins where many small, isolated outcrops have been preserved, usually in flat to topographically low lying areas that surround high-standing pressure ridges and (or) tumuli of older, underlying lava flows.

Despite their similarities in physical characteristics, each trachyte unit can be distinguished by integrating their physical appearances and their petrographic and geochemical characteristics; for example, trace-element abundances (Downs, 2019) of juvenile clasts are distinct for almost every pyroclastic deposit. Other criteria such as mineral textures and other physical differences such as color were used to distinguish various pyroclastic deposits in the southern part of the map area; for example, unit tef is petrographically distinct from the similarly aged units tg4 and tg5, the latter two of which are identical physically (that is, in appearance), petrographically, and geochemically. All three units can be distinguished both in the field and by using satellite photogrammetry on the basis of their colors and morphologies: unit tef is bright yellow and has a bedded appearance, whereas unit tg4 is tan and massive and unit tg5 is green and massive.

Cryptodomes are geomorphic features that have a lava dome-like morphology but have no juvenile volcanic material that breached the surface; they can reach more than $1 \mathrm{~km}$ in diameter and be uplifted more than $100 \mathrm{~m}$ above the surrounding topography. Surfaces of the uplifted areas are commonly broken and jumbled owing to extension and cracking of the overlying volcanic deposits, but the uplifted rocks are continuous into adjacent areas that were not uplifted. Four cryptodomes are present in the map area (see sheets 1,3). These features are interpreted as having formed as evolved magma (probably of trachyte composition) reached the near surface, then it spread beneath, and eventually uplifted, the older volcanic rocks. The four mapped cryptodomes are (1) Dabaa 2, which uplifted lava flows of unit hd2 (precise age unknown but part of eruptive stage 5), (2) Dabaa 3, which uplifted lava flows of units bd3 (307.7 $\pm 4.6 \mathrm{ka})$ and muq $(385.6 \pm 12.6 \mathrm{ka})$, (3) As Zayinah, which uplifted lava flows and scoria-cone material of units mnzy (461.2 $\pm 6.2 \mathrm{ka})$ and mzy (410.3 $\pm 3.4 \mathrm{ka})$, and (4) an unnamed cryptodome about $400 \mathrm{~m}$ south of the Gura 5 crater, which uplifted pyroclastic deposits of unit tg5 (79.7 $\pm 1.6 \mathrm{ka})$.

Figure 8 (on sheet 4). Photograph to west-northwest, showing $1.9-\mathrm{km}$-long fissure vent that erupted the basalt of Central Finger (unit bcef, 24.4 $\pm 1.3 \mathrm{ka}$; sections A2, B2). Also identified are lava flows and scoria cones of several nearby units. Photograph by Hannah Dietterich, 2016. Figure is on sheet 4; caption included here for continuity.

Figure 9 (on sheet 4). Photograph to north-northwest, showing domes of the trachyte of Mouteen (unit tmo, 31.9 $\pm 2.1 \mathrm{ka}$; section D2) and the trachyte of Matan (unit tma, 121.5 \pm 1.4 ka; sections C2, D2). Each high-standing lava dome has small central craters and apron of pyroclastic-flow deposits that overlie basalt and mugearite lava flows. Also identified are uplifted lava flows of the hawaiite of Mouteen (unit hmo, 239.0 \pm 4.1 ka). Photograph by Hannah Dietterich, 2016. Figure is on sheet 4; caption included here for continuity.

Figure 10 (on sheet 4). Photograph to southeast, showing pancake lava dome of the trachyte of Um Znabah 1 (unit tz1, 269.1 $\pm 5.0 \mathrm{ka}$; section E2). Behind it is high-standing scoria cone, vent for the mugearite of Um Znabah 2 (unit mz2, 195.9 1.3 ka; sections D2, E2). To left of scoria cone (unit $\mathrm{mz} 2$ ) is lava spine of the trachyte of Um Rgaibah (unit trg, 4.2 $\pm 5.2 \mathrm{ka}$; section E2). Also identified are lava flows, pyroclastic-flow deposits, crater rim, and scoria cone of several nearby units. Photograph by Andrew Calvert, 2014. Figure is on sheet 4; caption included here for continuity.

Figure 11 (on sheet 4). Photograph to southeast, showing crater that formed during eruption of the trachyte of Gura 3 (unit tg3, $142.4 \pm 2.2 \mathrm{ka}$; section D2). Remnant of the basalt of Gura 3 (unit bg3, 1,112.1 $\pm 17.6 \mathrm{ka}$; section D2) is exposed on crater floor; visible in crater wall are the benmoreite of Gura 3 (unit og3, 558.7 $\pm 4.8 \mathrm{ka}$; section D2) and the basalt of Ad Darah (unit bda, 223.0 $\pm 18.9 \mathrm{ka}$; section D2). Also identified are cryptodome, lava spine, block-andash-flow deposits, pyroclastic-flow deposits, and scoria cones of several nearby units. Light-yellowish-tan sediment within unit tg3 on crater floor is alluvium (unit Qal). Photograph by Hannah Dietterich, 2016. Figure is on sheet 4; caption included here for continuity.

\section{Petrographic Characteristics of Volcanic Rocks}

All mafic volcanic rocks (that is, tholeiitic basalts, alkalic basalts, and hawaiites) from northern Harrat Rahat have broadly similar petrographic characteristics, and their groundmass assemblages are similar in that olivine, plagioclase, clinopyroxene, iron-titanium (Fe-Ti) oxides, glass, and trace abundances of apatite are consistent. The mafic volcanic rocks range in texture from aphyric to being dominated by olivine (some have chromium $[\mathrm{Cr}]-$ rich spinel inclusions) and (or) plagioclase phenocrysts. Olivine phenocrysts are normally zoned, range in abundance from 1 to 15 percent, and are commonly between 1 and $5 \mathrm{~mm}$ in size but can 
be as large as $30 \mathrm{~mm}$ in some basalts; they range in color from dark- to pale-green and from honey-yellow to varying degrees of reddish-brown (iddingsite), and they display resorbed to partly resorbed, corroded, and skeletal textures. Plagioclase phenocrysts have a similar range of petrographic characteristics in that they are normally zoned and typically are euhedral, having minor resorbed phenocrysts that contain overgrowth rims; they range in abundance from 1 to 15 percent, and they commonly are less than $10 \mathrm{~mm}$ in size but can be as large as $70 \mathrm{~mm}$. Pyroxene phenocrysts are exceptionally rare within Harrat Rahat mafic volcanic rocks; the only observed mafic volcanic-rock unit that has pyroxene phenocrysts is unit bsj (eruptive stage 8), which contains 1 percent clinopyroxene phenocrysts as large as $1 \mathrm{~mm}$. However, clinopyroxene is pervasive as an interstitial phase in the groundmass. Similarly, equant to subequant Fe-Ti oxides that range in size from 10 to more than 100 $\mu \mathrm{m}$ are present throughout the groundmass of these rocks.

Tholeiitic basalts typically have a coarse-grained, diktytaxitic groundmass, but some have a groundmass that is holocrystalline with seriate textures. These basalts can be aphyric, although they are more commonly phenocryst rich. Olivine is usually the only phenocryst phase, ranging in abundance from 5 to 10 percent and having euhedral, corroded, or skeletal textures. Olivine phenocrysts in northern Harrat Rahat tholeiitic basalts commonly contain dark-green to brown, Cr-rich spinel inclusions. The spinels that are located close to olivine rims or along cracks in olivine phenocrysts have rims of Fe-Ti oxides, whereas spinels present within the groundmass are Fe-Ti oxides consisting of magnetite and titanomagnetite. Plagioclase is mostly restricted to elongate laths in the groundmass, as is clinopyroxene.

Mugearites have groundmass assemblages of olivine, plagioclase, clinopyroxene, Fe-Ti oxides, glass, and trace abundances of apatite and amphibole. These volcanic rocks range in texture from aphyric to containing phenocrysts of olivine, plagioclase, and clinopyroxene. Olivine phenocrysts are normally zoned, are from 1 to 2 percent in abundance, can be as large as $15 \mathrm{~mm}$, and have textures that range from resorbed to corroded to skeletal. Plagioclase phenocrysts display both normal and reverse zoning, are generally resorbed, have textures that range from sieved to euhedral, range in abundance from 1 to 5 percent, and can be as large as $15 \mathrm{~mm}$. Euhedral clinopyroxene phenocrysts are present in some mugearites in approximately 1 percent abundance and are as large as $1 \mathrm{~mm}$.

Benmoreites range in texture from aphyric to containing phenocrysts of olivine, potassium (K)-rich feldspar, plagioclase, and clinopyroxene (augite to, more rarely, aegirine). Their groundmass assemblages are dominated by K-rich feldspar, plagioclase, and glass, with minor abundances of clinopyroxene, Fe-Ti oxides, apatite, and, in some cases, olivine and amphibole. Olivine in benmoreites have fayalite compositions, range in abundance from 1 to 3 percent, and are as large as $3 \mathrm{~mm}$. Plagioclase phenocrysts are present, but feldspar populations are dominated by blocky, K-rich anorthoclase and sanidine from 1 to 15 percent and as large as 20 $\mathrm{mm}$. Most pyroxene phenocrysts are augite, in abundances from 1 to 3 percent and as large as $4 \mathrm{~mm}$, but with trace abundances of aegirine. Amphibole is present in trace abundances in the groundmass of the benmoreites, but a single benmoreite unit (ort [eruptive stage 5]) contains noticeable amphibole phenocrysts from 2 to 4 percent and as large as $4 \mathrm{~mm}$. Amphibole phenocrysts typically are heavily reacted to opaque Fe-Ti oxides along their rims.
Trachytes range in texture from aphyric to containing phenocrysts of anorthoclase and sanidine (to $10 \mathrm{~mm}$ ), but they, in some cases, are seriate, having abundant K-rich feldspar phenocrysts that range in size continuously from $1 \mathrm{~mm}$ to tens of micrometers. Some trachytes contain sparse phenocrysts of plagioclase, but all contain minor phenocrysts or microphenocrysts of clinopyroxene (augite to aegirine). Trachyte groundmass assemblages are dominated by K-rich feldspar and glass, as well as trace abundances of aegirine to augite, Fe-Ti oxides, apatite, zircon, and, rarely, fayalitic olivine.

\section{Eruptive History of Northern Harrat Rahat and its Environs}

The timing of volcanism in northern Harrat Rahat was initially presented by Camp and Roobol $(1989,1991)$ and was later modified by Moufti and others (2013). As previously stated, Camp and Roobol $(1989,1991)$ defined the Shawahit (10-2.5 Ma), Hammah (2.5-1.7 Ma), and Madinah (1.7 Ma to the present) basalts by using $25 \mathrm{~K}$-Ar ages compiled from Pellaton (1981), Coleman and others (1983), and their own work. Camp and Roobol $(1989,1991)$ overwhelmingly demonstrated that exposed volcanic rocks within Harrat Rahat become younger to the north and that northern Harrat Rahat is dominated by their subdivisions of the Madinah basalts (their subunits “Qm," through “ $Q \mathrm{~m}_{7}$ ”). Only four areas (designated herein as units bgh, bh89, bja, and part of unit bhu) in northern Harrat Rahat were assigned to the Hammah basalts by Camp and Roobol (1991). All these units have now been determined to be much younger than the 2.5- to 1.7-Ma Hammah time period.

Although absolute ages of the "Qm," through "Qm," Madinah basalt subunits were anchored by eight K-Ar ages, only two ages were deemed reliable by Camp and Roobol (1989, 1991). As a result, Camp and Roobol $(1989,1991)$ proposed that several of the Madinah basalt subunits ("Qm," through " $Q \mathrm{~m}_{3}$ ”) erupted between 1.7 Ma and $600 \mathrm{ka}$. They further interpreted that at least six eruptions in northern Harrat Rahat were postNeolithic in age ("Qm," subunit). This distinction was based on minimally eroded lava-flow surfaces lacking significant loessfilled depressions, as well as lacking Neolithic burial mounds on their surfaces. Thus, Camp and Roobol $(1989,1991)$ interpreted these lava flows as postdating the Neolithic pluvial interval, which was ${ }^{14} \mathrm{C}$ dated near Damascus, Syria, to be between 7,000 and 4,500 years ago (Kaiser and others, 1973). Later work showed that the Neolithic pluvial interval ended on the Arabian Peninsula closer to 6,000 years ago (McClure, 1978; Crassard and others, 2013). The eruptive products of two eruptions were assigned to the youngest " $Q \mathrm{~m}_{7}$ " historical subunit. These include the small-volume scoria cones and lava flows of unit bdu and the well-documented voluminous eruption of unit bla at 1256 C.E. Camp and Roobol $(1989,1991)$ assigned an age of 641 C.E. to unit bdu on the basis of its low degrees of erosion and the brief historical mention of an eruption at that time in the greater Al-Madinah region; however, unit bdu has been dated at $13.3 \pm 1.9 \mathrm{ka}$ (Downs and others, 2018), thereby invalidating the Camp and Roobol $(1989,1991)$ age assignment. 
Moufti and others (2013) attempted to redefine the eruptive history of northern Harrat Rahat by supplying $25^{40} \mathrm{Ar} /{ }^{39} \mathrm{Ar}$ ages for Camp and Roobol's (1991) "Qm," through "Qm," subunits. In general, their ${ }^{40} \mathrm{Ar} /{ }^{39} \mathrm{Ar}$ ages largely supported the age groups proposed by Camp and Roobol $(1989,1991)$, but their ages also yielded considerable overlap within the different subunits. Moufti and others (2013) also proposed that the ages of the volcanic rocks in northern Harrat Rahat extend back to $10.31 \mathrm{Ma}$, which is older than the initial age of Harrat Rahat volcanism known within this part of the volcanic field as mapped by Camp and Roobol $(1989,1991)$.

The mapping herein, which covers approximately 3,340 $\mathrm{km}^{2}$, distinguishes 239 individual volcanic units related to northern Harrat Rahat volcanism, not including isolated scoria cones that cannot be correlated with mapped lava flows. Of these 239 units, 180 are basalt, 13 are hawaiite, 19 are mugearite, 13 are benmoreite, and 14 are trachyte. Isotopic eruption ages have been determined for 115 units, or approximately one-half of the exposed volcanic rocks. A total of 108 units have been dated by the ${ }^{40} \mathrm{Ar} /{ }^{39} \mathrm{Ar}$ method; a complete list of ${ }^{40} \mathrm{Ar} /{ }^{39} \mathrm{Ar}$ ages is presented in table 2. Eruption ages for seven map units have been determined by ${ }^{36} \mathrm{Cl}$ cosmogenic surface-exposure dating; a complete list of ${ }^{36} \mathrm{Cl}$ cosmogenic surface-exposure ages is presented in table 3. The isotopic ages cluster somewhat, defining periods of increased or decreased volcanic activity, and these peaks and troughs in volcanism are the basis for reassigning the volcanic records of northern Harrat Rahat into eruptive stages (fig. 12).

In addition to absolute ages from ${ }^{40} \mathrm{Ar} /{ }^{39} \mathrm{Ar}$ and ${ }^{36} \mathrm{Cl}$ geochronology, age constraints on undated units have been estimated from bounding stratigraphic units that were directly dated. Stratigraphically constrained ages were used to place undated volcanic units into their appropriate eruptive stage. Additionally, paleomagnetic analyses (table 4) were used to correlate dated map units to geographically separate exposures or units that have matching remanent magnetic directions and other similar characteristics. In cases where paleomagnetic correlations could be made, the eruptive age for the directly dated map unit was assigned to the units that had not been directly dated.

Geochronology, geochemistry, paleomagnetic analysis, and field mapping lead to a significant reinterpretation herein of the eruptive history of northern Harrat Rahat. Major revisions to the eruptive history include (1) the ages of the oldest exposed volcanic units within northern Harrat Rahat are less than 1,200 ka, (2) those of 218 volcanic units are less than $600 \mathrm{ka}$ (contradicting Camp and Roobol's $[1989,1991]$ interpretation that most volcanic units erupted between $1.7 \mathrm{Ma}$ and $600 \mathrm{ka}$ ), and (3) only two Holocene eruptions occurred within northern Harrat Rahat (unit bla, at 1256 C.E., and unit trg, at $4.2 \pm 5.2 \mathrm{ka}$ ). All other units interpreted as being Neolithic to post-Neolithic by Camp and Roobol (1991) are shown to be late Pleistocene (that is, older than $11 \mathrm{ka}$ ), either by using ${ }^{40} \mathrm{Ar} /{ }^{39} \mathrm{Ar}$ and ${ }^{36} \mathrm{Cl}$ geochronology or by using stratigraphic relations with well-dated volcanic units.

In contrast to previous studies that defined stratigraphic subdivisions for the Madinah basalts on the basis of a combination of isotopic dating and geomorphic descriptions of volcanic rocks, we define herein 12 eruptive stages (fig. 12) for northern Harrat Rahat ( 1 being the youngest, and 12 being the oldest). Eruptions from stages 1 to 12 form the eruptive products of northern Harrat Rahat, whereas lavas from two older periods of volcanism are from surrounding volcanic fields and were not studied in detail; these are referred to as the volcanic rocks of Harrat Kurama (early Pleistocene units Qbhk, Qbjs, and Qbra) and the Tertiary volcanic rocks (Miocene units Tbja and Tbjj), on the basis of their isotopic age constraints.

\section{Tertiary Volcanic Rocks}

At least two mafic lava flows (units Tbja and Tbjj) predate the exposed volcanic rocks that are related to northern Harrat Rahat. Tertiary unit Tbja is characterized by phenocrysts of plagioclase $(10 \%, \leq 3 \mathrm{~mm})$ and olivine $(1 \%, \leq 3 \mathrm{~mm})$, whereas Tertiary unit Tbjj is characterized by phenocrysts of plagioclase $(1 \%, \leq 2 \mathrm{~mm})$, olivine $(1-3 \%, \leq 6 \mathrm{~mm})$, and clinopyroxene $(1 \%$, $\leq 5 \mathrm{~mm}$ ). Vent locations and extents of both units are unknown, but they are presumed to have come from north of the northern Harrat Rahat map area. These units are present only as outcrops that cap high-standing Precambrian hills, 200 to $350 \mathrm{~m}$ above the surrounding topography, and both units are located within and west of Al-Madinah (sections A1, B1). A ${ }^{40} \mathrm{Ar}{ }^{\beta 9} \mathrm{Ar}$ isotopic analysis from unit Tbja yielded an age of 13,562.0 $\pm 30.2 \mathrm{ka}$, although the complicated age spectrum for this sample indicates that this age should be treated as provisional. Unit Tbjj has not been dated but is presumed to be of similar Miocene age because its elevation is similar to that of unit Tbja. These lava flows have low $\mathrm{SiO}_{2}$ and high $\mathrm{K}_{2} \mathrm{O}, \mathrm{Ga}, \mathrm{Ba}, \mathrm{Rb}, \mathrm{Th}, \mathrm{U}, \mathrm{Ta}$, and $\mathrm{Nb}$ contents relative to mafic lavas of the Madinah basalts (Downs, 2019) and, thus, are considered to be unrelated to northern Harrat Rahat volcanism.

\section{Volcanic Rocks of Harrat Kurama}

Three alkalic to tholeiitic basalts (units Qbhk, Qbjs, and Qbra) are exposed near the northern and northeastern margins of the map area (sections A1, A2). Vent locations and extents of these lava flows are unknown, as they originated from outside the map area. However, their directions of slope suggest that they originated northeast of where they are exposed, indicating that the three units erupted from the Harrat Kurama volcanic field, located northeast of northern Harrat Rahat (Coleman and others, 1983). These lavas apparently flowed through rugged, high-standing Precambrian hills to their present locations near northern Harrat Rahat. Unit Qbra has a ${ }^{40} \mathrm{Ar}{ }^{39} \mathrm{Ar}$ age of 2,140.0 $26.0 \mathrm{ka}$, which places it in the early Pleistocene. Unit Qbjs sits atop Precambrian rocks that are surrounded by unit Qbra lava flows. However, unit Qbjs is presumed to be older than unit Qbra; its higher elevation is interpreted to be the result of inverted topography. These early Pleistocene basalts fall within the geochemical range of mafic magmas in Harrat Rahat-related basaltic volcanism.

\section{Volcanic Rocks of Northern Harrat Rahat}

\section{Eruptive Stage 12 (1,200 to $780 \mathrm{ka}$ )}

Six volcanic units mapped in the northern Harrat Rahat volcanic field erupted between 1,200 and $780 \mathrm{ka}$, designated as eruptive stage 12 , the oldest eruptive stage. The oldest isotopically dated 


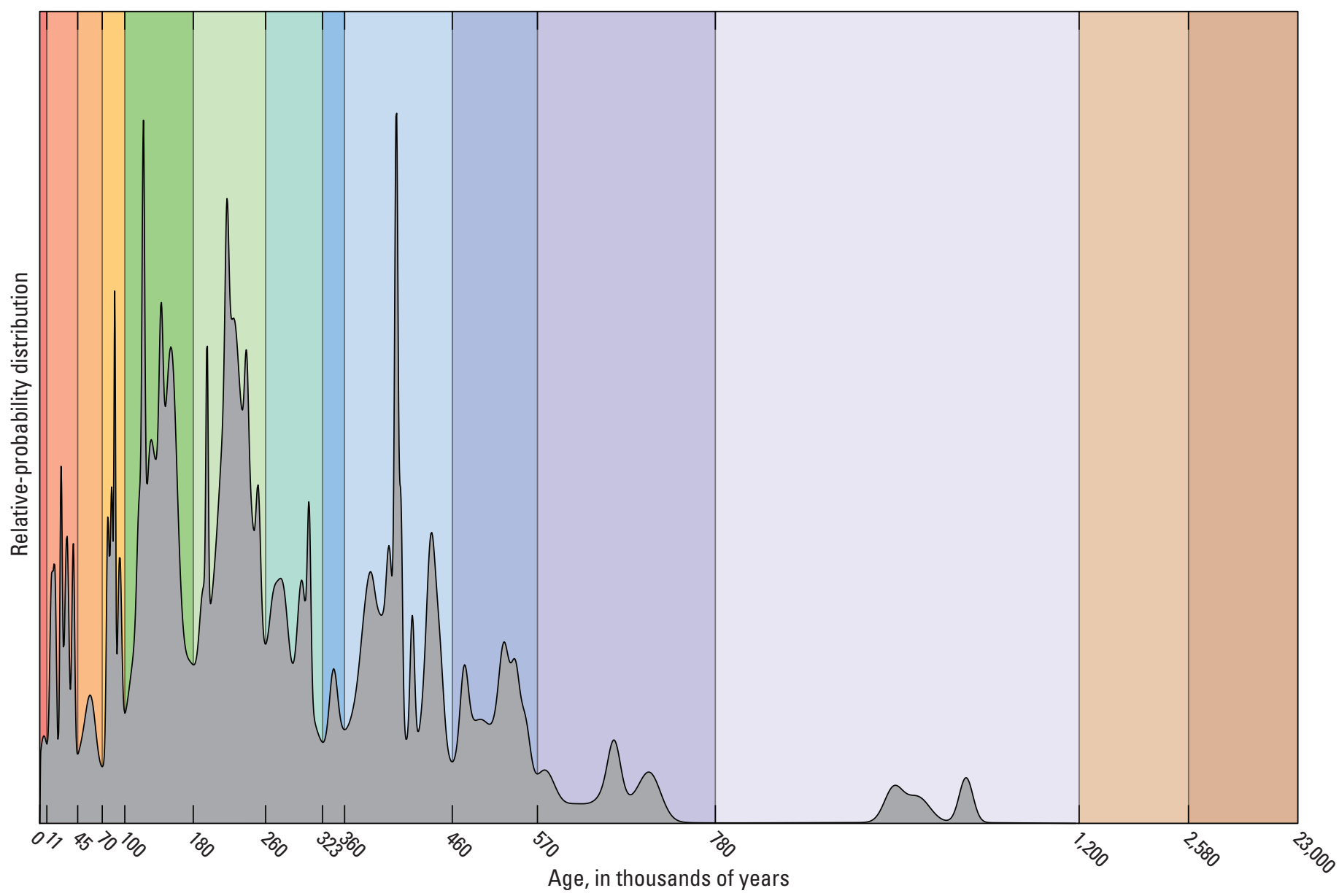

\section{EXPLANATION}

Relative-probability distribution of ages in northern Harrat Rahat volcanic field

Eruptive stages (from youngest to oldest) of northern Harrat Rahat volcanic field

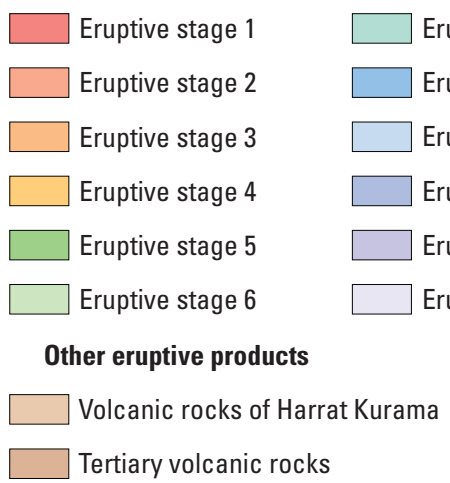

Figure 12. Relative-probability distribution versus age (gray peaks and troughs) for all ages in northern Harrat Rahat volcanic field. Ages include ${ }^{40} \mathrm{Ar} /{ }^{39} \mathrm{Ar}$ isotopic, ${ }^{36} \mathrm{Cl}$ cosmogenic surface-exposure, and both stratigraphically and paleomagnetically constrained ages. Relative-probability distribution represents frequency of eruptions while accounting for uncertainty in each eruption age; peaks and troughs were used to define 12 eruptive stages. Colors of eruptive stages (and of Harrat Kurama and Tertiary volcanic rocks) in background match those used for map units on sheets 1, 2, and 3. Eruptive stages 1 through 12 encompass all northern Harrat Rahat-related volcanic activity; age breaks correspond to those shown in Description of Map Units and also in Correlation of Map Units (on sheet 4). Volcanic rocks of Harrat Kurama encompass units Qbhk, Qbjs, and Qbra, which erupted northeast of northern Harrat Rahat, whereas Tertiary volcanic rocks encompass units Tbja and Tbjj, which erupted from undetermined location north of northern Harrat Rahat. volcanic product in northern Harrat Rahat is an unnamed benmoreite lava, dated at $1,137.9 \pm 3.1 \mathrm{ka}$, that underlies unit og4 (316.4 \pm 2.1 $\mathrm{ka})$; however, it is too sparsely exposed to be mapped. Parts of units bgh, bh89 (1,014.0 $\pm 14.0 \mathrm{ka})$, bhu $(285.1 \pm 6.6 \mathrm{ka})$, and bja (698.1 $\pm 16.0 \mathrm{ka})$ were mapped by Camp and Roobol $(1989,1991)$ as the Hammah basalts $(2.5-1.7 \mathrm{Ma})$, but our ${ }^{40} \mathrm{Ar} /{ }^{39} \mathrm{Ar}$ ages demonstrate that these units are all younger than $1.7 \mathrm{Ma}$, and, as such, no evidence exists that any exposed volcanic rocks in the map area are the Hammah basalts as designated by Camp and Roobol (1989, 1991) and Moufti and others (2013). Older volcanic rocks undoubtedly exist in the subsurface but have yet to be sampled by drill core.
Volcanic rocks that erupted during stage 12 are sparsely exposed owing to burial by younger volcanism in northern Harrat Rahat. All six exposed volcanic units identified as falling within eruptive stage 12 are basalts (both alkalic and (or) tholeiitic). Basalts of stage 12 have ${ }^{40} \mathrm{Ar} /{ }^{39} \mathrm{Ar}$ ages that range from $1,112.1 \pm 17.6$ to $1,014.0 \pm 14.0 \mathrm{ka}$; in addition, two undated basalts are assigned to this stage. These basalts are of limited aerial extent but are present throughout the map area (sections A1, B1, C1, D2, $E 1, E 2, F 1, F 2)$, which indicates that basalts erupted from all parts of the map area during this stage. The unnamed and unmapped benmoreite lava that underlies unit og4 (316.4 $\pm 2.1 \mathrm{ka}$; section E2) 
is very sparsely exposed within the base of the crater that formed during the eruption of unit $\operatorname{tg} 4(84.3 \pm 1.6 \mathrm{ka})$. The identification of this benmoreite lava indicates that evolved magmas have erupted along the main vent axis since at least $1,137.9 \pm 3.1 \mathrm{ka}$. No units have been directly dated as being between 1,014 and $780 \mathrm{ka}$, which has resulted in a large apparent gap in volcanism (fig. 12); however, it is currently unknown whether this gap in volcanism reflects a true hiatus in eruptive activity or simply the concealment of eruptive products by younger volcanism.

\section{Eruptive Stage 11 (780 to $570 \mathrm{ka})$}

Thirteen volcanic units are mapped in northern Harrat Rahat that erupted during eruptive stage 11, between 780 and $570 \mathrm{ka}$, of which 12 are basalts and one is a mugearite. It is likely that more eruptions occurred during stage 11 than are presently exposed, but their products are obscured by younger volcanic rocks. The basaltic lava flows include units bsl and buq, which are tholeiitic, and unit bd1, which is both alkalic and tholeiitic; all nine remaining basaltic units (bas, bat, bba, bg1, bja, bmy, bsd, bsw, and bush) are alkalic. Basalts of eruptive stage 11 appear as limited outcrops throughout the map area (sections A1, A2, D1, D2, E1, E2), most of which erupted from either the main vent axis or the subsidiary vent axis to the west.

The only mugearite of stage 11 (unit mss; section E2) erupted at $621.8 \pm 24.0 \mathrm{ka}$ from the main vent axis, near the crater that formed during the eruption of unit osa. Thus, it appears that stage 11 was dominated by tholeiitic and alkalic basalt volcanism, similar to stage 12 .

\section{Eruptive Stage 10 (570 to $460 \mathrm{ka}$ )}

The number of exposed volcanic units that erupted between 570 and $460 \mathrm{ka}$, designated as eruptive stage 10, represents a significant increase in units observed in northern Harrat Rahat. In total, 33 units that erupted during stage 10 are mapped, including 30 basalts, one hawaiite, and two benmoreites. The basalts include units bqu, bh82, and bfa, which are tholeiitic, and unit brg, which is both alkalic and tholeiitic; all remaining basalts are either alkalic or lack geochemical data. The basalts are distributed throughout the map area, appearing as partly exposed lava flows in sections A1, A2, B1, C1, C2, D1, D2, E1, E2, and F2. Although not all vent locations for each basaltic unit are known, basaltic volcanism was not spatially clustered during this stage. These eruptions were from both the main and subsidiary vent axes, as well as in the northernmost part of the map area.

The only hawaiite assigned to stage 10 (unit hhil) erupted at $490.1 \pm 4.6 \mathrm{ka}$ from the southern part of the main vent axis (sections E2, F2). Units og3 (558.7 $\pm 4.8 \mathrm{ka}$ ) and osb $(535.8 \pm 11.8 \mathrm{ka})$ are the only benmoreites to have erupted during stage 10 . Unit og3 is exposed in the northern wall of the crater that formed during the $142.4 \pm 2.2$ ka eruption of unit tg3 (section D2; see also, fig. 11, on sheet 4). Although the extent of unit og3 cannot be determined owing to its limited exposure, it apparently erupted from the main vent axis. Unit osb (section D2) forms a 4.5-km-long lava flow that extends to the northeast; its vent location is concealed by younger volcanic rocks of unit oju (424.2 $\pm 1.8 \mathrm{ka}, 437.6 \pm 4.3 \mathrm{ka})$, but it erupted from the main vent axis as well. Despite similar ages for units osb and og3, they have distinct chemical compositions, precluding the possibility of them being part of the same eruption.

Overall, basaltic volcanism during stage 10 was diffusely distributed throughout the map area, but evolved volcanism erupted exclusively from the main vent axis. This observation is similar to the distribution of volcanic rocks from stages 11 and 12 .

\section{Eruptive Stage 9 ( 460 to $360 \mathrm{ka}$ )}

The frequency of volcanism increased significantly in northern Harrat Rahat during eruptive stage 9, between 460 and $360 \mathrm{ka}$. Products of 51 eruptions during stage 9 are distinguished, which makes it one of the most vigorous eruptive stages. Of these 51 eruptions, 34 are basalts (only four are tholeiitic); one is hawaiite, nine are mugearites, five are benmoreites, and two are trachytes. Volcanism during this eruptive stage was similar to that of stages 10,11 , and 12 in that most volcanic activity was basaltic, but the number of evolved eruptions increased significantly relative to earlier stages.

Basalts from this eruptive stage are mapped in sections A1, B1, C1, C2, D1, D2, E1, E2, F1, and F2. Most basalts are exposed in sections $\mathrm{D}, \mathrm{E}$, and $\mathrm{F}$, along the southwestern and southern margins of the map area, which indicates that basalts erupted predominantly in the southern part of the map area; however, stage 9 basalts are scattered throughout the map area. The paucity of basalts that erupted during stage 9 in the northern part of the map area is thought to reflect concealment by younger lava flows, which is supported by the observations that (1) volcanic rocks from younger eruptive stages dominate the northern part of the map area and (2) stage 9 units are present only as isolated outcrops along the northern margin of northern Harrat Rahat. Many basalts from eruptive stage 9 are present as broad lava flows along the southern and southwestern margins of the map area, indicating that many of these lava flows were emplaced from the subsidiary vent axis. However, several of these basalts, as well as the single hawaiite erupted during stage 9, also appear to have erupted from the main vent axis and flowed towards the eastern margin of the volcanic field. These observations indicate that mafic volcanism was not spatially clustered during stage 9; instead, the entire northern part of northern Harrat Rahat was active during that time.

The nine mugearites, five benmoreites, and two trachytes associated with eruptive stage 9 all erupted from the main vent axis. The mugearites and benmoreites (sections D2, E2, F2) display a range of characteristics. Units $\mathrm{Oz} 4(430.2 \pm 6.9 \mathrm{ka}), \mathrm{Oz} 5$, and ozy $(418.8 \pm 1.9 \mathrm{ka})$, located at the south end of the main vent axis (section E2), formed lava flows, whereas unit osa (sections D2, E2) is unique among benmoreites in northern Harrat Rahat in that it erupted explosively, forming block-and-ash-flow and pyroclasticflow deposits sourced from a $0.5-\mathrm{km}$-diameter crater. Unit oju (section D2) erupted during two phases: the first, which erupted at $437.6 \pm 4.3 \mathrm{ka}$, consists of pyroclastic-flow deposits and a $225-\mathrm{m}-$ tall lava dome capped by a series of short, viscous lava flows and pyroclastic-flow deposits, whereas the second phase, which erupted at $424.2 \pm 1.8 \mathrm{ka}$, consists of a single, small lava dome.

Eruptive stage 9 marks the first appearance of trachyte in the northern Harrat Rahat volcanic field (section E2). Unit tz6 consists of a small, aphyric lava dome, whereas unit 
tqa consists of pyroclastic-flow deposits. Both are located at the south end of the main vent axis, and both are spatially associated with units oz4, oz5, and ozy.

\section{Eruptive Stage 8 (360 to $323 \mathrm{ka}$ )}

Eruptive stage 8, between 360 and $323 \mathrm{ka}$, represents a relative lull in volcanism in northern Harrat Rahat (see fig. 12). During this stage, only five eruptions are identified, all of which are basaltic. These include the alkalic basalts of units bjab, bsm, bmu, and blsa, as well as the tholeiitic basalt of unit bsj (sections A1, A2, B1, D1, D2, E1, E2, F2). As such, the volcanic rocks from stage 8 are not spatially clustered but, instead, have a diffuse distribution throughout the map area. However, only unit bsm appears to have erupted from the main vent axis. It is possible that more eruptions occurred during stage 8 but are covered by younger volcanic rocks, especially if they erupted from the main vent axis. Nevertheless, it is presumed that the inferred lull in volcanism observed during stage 8 represents an actual decrease in the frequency of volcanism.

\section{Eruptive Stage 7 (323 to $260 \mathrm{ka}$ )}

Sixteen units are mapped as eruptive stage 7, between 323 and $260 \mathrm{ka}$, in northern Harrat Rahat, including 14 basalts, one benmoreite, and one trachyte. The basalts encompass 11 units that are alkalic and three that are both alkalic and tholeiitic. Basalts erupted during this stage are mapped in sections A1, B1, $\mathrm{C1}$, D1, D2, E1, E2, F1, and F2. It is apparent from the distribution of basalts that volcanism was not spatially clustered, as basalts erupted from both the main and subsidiary vent axes. The best exposed basalts are in the southwestern part of the map area (sections E1, E2, F1, F2) where younger volcanic rocks from eruptive stages 1 through 5 are not present. One unit (bhu) was previously mapped as being part of the Hammah basalts (2.5-1.7 Ma) by Camp and Roobol (1991) on the basis of its shieldvolcano morphology; a new ${ }^{40} \mathrm{Ar} /{ }^{39} \mathrm{Ar}$ date demonstrates that unit bhu erupted at 285.1 $\pm 6.6 \mathrm{ka}$ (Downs and others, 2018).

Evolved volcanism was limited during eruptive stage 7. The only benmoreite to erupt during this stage is unit og4 $(316.4 \pm 2.1 \mathrm{ka})$, which has a very limited exposure in the crater wall that formed during the explosive trachyte eruption of unit tg4 at $84.3 \pm 1.6 \mathrm{ka}$. Unit tz1 $(269.1 \pm 5.0 \mathrm{ka})$, which is the only trachyte to have erupted during eruptive stage 7 , forms an aphyric, 0.8-km-diameter circular pancake lava dome (fig. 10, on sheet 4). Both units og4 and tz1 erupted from the southern part of the main vent axis (section E2).

\section{Eruptive Stage 6 (260 to $180 \mathrm{ka}$ )}

Eruptive stage 6, between 260 and $180 \mathrm{ka}$, represents the largest number of eruptions exposed in the northern Harrat Rahat volcanic field. At least 53 units are mapped over the course of this 80-k.y. eruptive stage, of which 43 are basalt, three are hawaiite, five are mugearite, and two are benmoreite. The basalts include 38 units that are alkalic, three that are both alkalic and tholeiitic, and three that are tholeiitic. Basalts, which are distributed over both the main and subsidiary vent axes, have been mapped in all sections except E2 during this stage. Hawaiites from this stage erupted predominantly along the main vent axis (sections D2, E2, F2), except for unit hma, which erupted from the northern part of the map area, east of the main vent axis (sections A2, B2). Mugearites and benmoreites are associated exclusively with the main vent axis, as is true of all previous eruptive stages. Similar to hawaiites, mugearites erupted along the length of the main vent axis (sections D2, E2, F2), but benmoreites erupted only near the north end of the main vent axis (section D2). Hawaiites and mugearites are dominantly lava flows, whereas benmoreites formed lava domes and block-and-ash-flow deposits.

A unique feature of eruptive stage 6 , relative to previous stages, is that the timing of volcanism seems to be highly clustered around $225 \mathrm{ka}$ (fig. 12). In contrast, eruptive stage 9 had a similar number of eruptions (51 eruptions over 100 k.y.) but were erupted over a longer time period (fig. 12). After stage 6 , volcanism in northern Harrat Rahat became more clustered, both spatially and temporally.

\section{Eruptive Stage 5 (180 to $100 \mathrm{ka}$ )}

During eruptive stage 5, from 180 to $100 \mathrm{ka}, 36$ eruptions occurred in northern Harrat Rahat, of which 22 are basalt (three of which are tholeiitic), five are hawaiite, three are mugearite, three are benmoreite, and three are trachyte. Eruptive stage 5 displays a distinctive spatial distribution when compared to previous eruptive stages. During previous stages, basalts erupted from both the main and subsidiary vent axes, whereas the more evolved eruptions occurred exclusively from the main vent axis; however, during stage 5, nearly all eruptions, regardless of composition, occurred along the trend of the main vent axis. The three exceptions are units bka, bna, and bun, which erupted along the northwestern and northeastern margins of the volcanic field. No eruptions occurred within the southwestern part of the map area (sections D1, E1, F1) along the subsidiary vent axis, but some lava flows that erupted from the main vent axis did reach this area.

Basalt and hawaiite lava flows dominated in the northern part of the map area during eruptive stage 5 (sections $A 1, A 2$, $B 1, B 2, C 1, C 2)$, but no mugearite, benmoreite, or trachyte erupted in these sections during this stage. Mugearite, benmoreite, and trachyte erupted exclusively from the main vent axis in sections D2, E2, and F2, which is consistent with the distribution of these compositions during previous eruptive stages. Basalts and hawaiites also erupted along the main vent axis in sections D2, E2, and F2, but the number of eruptions of these compositions in these sections was significantly lower than in sections $A 1, A 2, B 1, B 2, C 1$, and C2. These observations demonstrate that, during stage 5 , the spatial distribution of both mafic and silicic eruptions became focused along the main vent axis.

Volcanism during stage 5 was temporally clustered. Following a brief lull in volcanic activity from 175 to $155 \mathrm{ka}$ (fig. 12), the rate of volcanism increased considerably. Most volcanic rocks of stage 5 erupted between 155 and $125 \mathrm{ka}$; after this, between 125 and $100 \mathrm{ka}$, the rate of volcanic activity decreased. 


\section{Eruptive Stage 4 (100 to $70 \mathrm{ka}$ )}

After the decrease in volcanic activity between 125 and $100 \mathrm{ka}$, eight eruptions occurred in northern Harrat Rahat during a brief time period, from 94 to $80 \mathrm{ka}$. Their products include two basalts, one hawaiite, one mugearite, and four trachytes. Eruptive stage 4 is, therefore, characterized by trachyte eruptions that were more frequent than in previous eruptive stages. Similar to the preceding stage 5, no units in stage 4 erupted from the subsidiary vent axis or are mapped in the southwestern part of the map area. Basalt, hawaiite, and mugearite assigned to stage 4 are located only in the northern part of the volcanic field, along the projected trend of the main vent axis (sections A1, B1, C1, C2), and they flowed northward or northeastward, toward Al-Madinah. Trachyte erupted from the more southern part of the main vent axis (sections D2, E2).

Trachytes associated with stage 4 include units tg2 (93.8 $\pm 2.1 \mathrm{ka})$, tef $(88.0 \pm 1.8 \mathrm{ka}), \operatorname{tg} 4(84.3 \pm 1.6 \mathrm{ka})$, and tg5 $(79.7 \pm 1.6 \mathrm{ka})$. All four units erupted explosively, forming pyroclastic-flow and -surge deposits. The explosive eruption of unit tg2 was preceded by the formation of a lava dome that was largely destroyed as a result of subsequent explosive activity. The eruption of unit tef is the largest explosive eruption recognized in northern Harrat Rahat, having pyroclastic deposits that extended at least $9 \mathrm{~km}$ from its source. The eruptions of units $\operatorname{tg} 2$, $\operatorname{tg} 4$, and $\operatorname{tg} 5$ were comparatively smaller, extending at least $3.0,5.5$, and $1.7 \mathrm{~km}$, respectively, from their sources.

Units tef, $\operatorname{tg} 4$, and $\operatorname{tg} 5$ are within close spatial proximity to each other, whereas unit tg2 lies $11.3 \mathrm{~km}$ northeast of the crater from which unit tg4 erupted. Field exposures show that unit tef $(88.0 \pm 1.8 \mathrm{ka})$ underlies both units $\operatorname{tg} 4(84.3 \pm 1.6 \mathrm{ka})$ and tg5 (79.7 $\pm 1.6 \mathrm{ka})$, consistent with their ${ }^{40} \mathrm{Ar} /{ }^{39} \mathrm{Ar}$ ages. Both units $\operatorname{tg} 4$ and tg5 have ${ }^{40} \mathrm{Ar} /{ }^{39} \mathrm{Ar}$ ages within analytical uncertainty, as well as matching geochemical compositions (Downs, 2019) and remanent-magnetic directions (table 4), which indicates that both units erupted during a brief time period (that is, at virtually the same time) and that they tapped the same magma batch.

\section{Eruptive Stage 3 (70 to $45 \mathrm{ka}$ )}

Following the eruption of unit tg5 at $79.7 \pm 1.6 \mathrm{ka}$ (eruptive stage 4), no eruptions occurred in northern Harrat Rahat for approximately 20 k.y. Eruptive stage 3, a brief period from 70 to $45 \mathrm{ka}$, encompassed only two eruptions, including one of alkalic basalt (unit bms) and one of hawaiite (unit han3). Unit han3 directly overlies unit bms, and their scoria cones are separated by only $2.3 \mathrm{~km}$. Dating by the ${ }^{36} \mathrm{Cl}$ cosmogenic surfaceexposure method yields results that are consistent with observed field relations, namely that the eruption of unit bms at 59.1 \pm 5.7

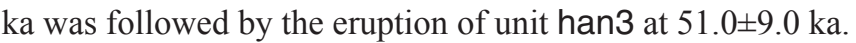
Both erupted just west of the main vent axis (sections C1, C2). Both units formed long, branching lava flows that traveled westward, southwestward, and northwestward, away from the main vent axis. Unit bms extended as much as $26.7 \mathrm{~km}$ from its scoria cone, reaching the western margin of the volcanic field, whereas unit han 3 extended as much as $19.7 \mathrm{~km}$ from its scoria cone, reaching the third ring road of Al-Madinah. These lava flows dominate the landscape in sections $\mathrm{C} 1$ and $\mathrm{C} 2$, and they were the only eruptions during what was otherwise a period of minimal volcanic activity.

\section{Eruptive Stage 2 (45 to $11 \mathrm{ka}$ )}

Following another hiatus, volcanism resumed during eruptive stage 2 , from 45 to $11 \mathrm{ka}$; of the nine eruptions, five were basalt, one was hawaiite, and three were trachyte. The distribution of volcanic rocks from eruptive stage 2 is similar to that mapped for eruptive stages $3,4,5$, and 6 . Basalt was the only composition to erupt in the northern part of the map area (sections A1, A2, B1, B2, C2) during stage 2. Unit bdw erupted at $25.6 \pm 16.2 \mathrm{ka}$ along the projected trend of the main vent axis, and part of it now resides within the third ring road that surrounds Al-Madinah. In Al Du'aythah, a western suburb of Al-Madinah, is unit bdu, which produced four small-volume scoria cones and two short (100 m) lava flows. Previously (Camp and Roobol, 1989; Murcia and others, 2015), this unit was interpreted to have erupted in 641 C.E., but a ${ }^{36} \mathrm{Cl}$ cosmogenic surface-exposure age demonstrates that it erupted at $13.3 \pm 1.9 \mathrm{ka}$ (Downs and others, 2018). Murcia and others (2015) provided a detailed description of the physical and geochemical characteristics of unit bdu.

Three basalt units (bcef, bnof, and bsof) erupted from a fissure system aligned in a north-northwest-trending direction, just east of the crest of the main vent axis. All three units were previously interpreted to have erupted in post-Neolithic time (Camp and Roobol, 1989), but our ${ }^{36} \mathrm{Cl}$ cosmogenic surfaceexposure ages show that units bcef, bnof, and bsof erupted at $29.1 \pm 3.7,22.0 \pm 3.3$, and $24.0 \pm 1.5 \mathrm{ka},{ }^{1}$ respectively. Field relations demonstrate that unit bcef underlies both units bnof and bsof, but the latter two lava flows are not in direct contact. Paleomagnetic studies demonstrate that all three units have distinct remanentmagnetic directions, which indicates that they erupted at slightly different times, which is supported by the slight geochemical and petrographic differences between units bcef, bnof, and bsof. Given the overall similarity in geochemical compositions of these three units and their overlapping ${ }^{36} \mathrm{Cl}$ cosmogenic surface-exposure ages, they have been assigned herein an age of $24.4 \pm 1.3 \mathrm{ka}$; however, it is recognized that they likely erupted centuries apart.

During eruptive stage 2 , the only hawaiite (unit hkh) erupted at $29.0 \pm 3.9 \mathrm{ka}$ in the southern part of the map area (section F2) and flowed southwestward approximately $12.4 \mathrm{~km}$ from its scoria cone. Paleomagnetic data (table 4) indicate that this unit erupted during a geomagnetic excursion, which, for this time period, corresponds to the Mono Lake excursion (Oda, 2005).

Two of the three trachytes (units tmo [31.9 $\pm 2.1 \mathrm{ka}]$ and td 1 $[17.6 \pm 1.8 \mathrm{ka}]$ ) erupted from the main vent axis (sections D2, F2), as is the case for nearly all trachytes erupted throughout the history of northern Harrat Rahat. The eruptions of both units tmo and td1 started with explosive phases that generated pyroclasticflow deposits and concluded with the emplacement of steepsided lava domes. Unit twa (39.2 $\pm 1.6 \mathrm{ka})$ is unique among the trachytes in that it erupted $8 \mathrm{~km}$ west of the main vent axis, and its explosive emplacement resulted in pyroclastic-flow deposits that extend at least $3.7 \mathrm{~km}$ from its crater.

${ }^{1}$ The $24.0 \pm 1.5 \mathrm{ka}$ age is the weighted mean of unit bsof ages. 


\section{Eruptive Stage 1 (11 to $0 \mathrm{ka}$ )}

Camp and Roobol $(1989,1991)$ proposed as many as eight eruptions in the northern Harrat Rahat volcanic field during the past 11 k.y., which encompasses the Holocene. Camp and Roobol $(1989,1991)$ mapped most of these young-appearing basaltic products close to Al-Madinah. However, our ${ }^{40} \mathrm{Ar} /{ }^{39} \mathrm{Ar}$ and ${ }^{36} \mathrm{Cl}$ ages indicate that only one certain Holocene eruption and one probable Holocene eruption occurred in northern Harrat Rahat: The certain Holocene eruption is that of the well-documented basaltic lava flow and vent complex of unit bla (sections A1, B1) in 1256 C.E., which erupted along the main vent axis and flowed northward for $22.8 \mathrm{~km}$ (see Camp and others, 1987, for a detailed description of this eruption). The probable Holocene eruption produced unit trg (section E2) at $4.2 \pm 5.2 \mathrm{ka}$; however, with its large age uncertainty, it may have erupted during the late Pleistocene. This eruption, which occurred near the southern part of the main vent axis, had not been previously identified as being Holocene. The first eruptive phase of unit trg was explosive, and it generated pyroclastic-flow deposits that reached at least $3.9 \mathrm{~km}$ northeast of its crater, which was infilled by a steep-sided lava dome (only a spine of which is currently preserved as its summit).

\section{Acknowledgments}

This research was funded by the Saudi Geological Survey (SGS) through a technical cooperative agreement between the SGS and U.S. Geological Survey (USGS). Dave Sherrod, Andy Calvert, Tim Orr, and Juliet Ryan-Davis (USGS), Gail Mahood (Stanford University), and Fawaz Muquyyim and Mahmod Ashur (SGS) are thanked for help with fieldwork. James Saburomaru, Dean Miller, Katie Sullivan, Brandon Swanson, and Eli Dawson (USGS) are thanked for help preparing samples for ${ }^{40} \mathrm{Ar}{ }^{\beta 9} \mathrm{Ar}$ dating experiments. We acknowledge Patrick Muffler and Julie Donnelly-Nolan (USGS) for thoughtful reviews that greatly improved this work.

\section{DESCRIPTION OF MAP UNITS}

[Surficial deposits are listed alphabetically by unit symbol. Quaternary volcanic rocks consist of undifferentiated vents (v), volcanic rocks of northern Harrat Rahat volcanic field, and volcanic rocks of Harrat Kurama. Volcanic rocks of northern Harrat Rahat volcanic field are subdivided into 12 eruptive stages (stage 1, youngest; stage 12, oldest); within each eruptive stage, units are listed alphabetically by unit symbol; first letter of unit symbol indicates composition of unit (b, basalt; $h$, hawaiite; $m$, mugearite; o, benmoreite; t, trachyte). Volcanic rocks not associated with northern Harrat Rahat volcanism are subdivided into volcanic rocks of Harrat Kurama (units Qbhk, Qbjs, and Qbra) and Tertiary volcanic rocks (units Tbja and Tbjj); these units also are listed alphabetically by unit symbol. Undifferentiated Precambrian rocks are labeled as p€. Basalts that have chemical analyses are termed either "alkalic basalt" or "tholeiitic basalt," whereas those that lack chemical analyses are termed simply "basalt;" phenocryst abundances (if known) and sizes are given in parentheses. Unless otherwise stated, all ages are reported at one-sigma error, and all geomagnetic excursion names and ages are from Oda (2005). Map is divided into sections to help locate units; capital letters and numbers (in brackets at ends of descriptions) correspond to map sections where units can be found (see fig. 3, on sheet 4). Tiny, unlabeled polygons are identified in database]

\section{SURFICIAL DEPOSITS}

al

Qal

Modern alluvium (Quaternary) — Fine sand, cobbles, and boulders, in present-day drainages. Derived from surrounding Precambrian and younger volcanic rocks. Concentrated around periphery of northern Harrat Rahat [A1, A2, B1, C1, D1, E1, F1]

Alluvium (Quaternary) - Alluvium, colluvium, loess, mud flat, and sabkha (Arabic for "salt flat") deposits. Present as large, flat, mud flat and sabkha deposits around periphery of northern Harrat Rahat; as alluvial fans and colluvium consisting primarily of Precambrian metamorphosed rocks; and as pockets of loess in low-lying areas of northern Harrat Rahat [A1, A2, B1, B2, C1, C2, D1, D2, E1, E2, F1, F2]

\section{QUATERNARY VOLCANIC ROCKS}

Undifferentiated vents (Quaternary) - Undifferentiated mafic vents of tholeiitic and alkalic basalt, hawaiite, and mugearite $\left(46.2-50.8 \% \mathrm{SiO}_{2} ; 0.33-2.20 \% \mathrm{~K}_{2} \mathrm{O}\right)$; not associated with any mapped units. Scattered throughout northern Harrat Rahat. Aphyric to containing phenocrysts of plagioclase $(1-8 \%, \leq 10 \mathrm{~mm})$ and olivine $(<1-3 \%, \leq 4 \mathrm{~mm})$. One vent has ${ }^{40} \mathrm{Ar} /{ }^{39} \mathrm{Ar}$ age of $986.2 \pm 10.7$ ka, but most cannot be dated [A1, A2, B1, B2, C1, C2, D1, D2, E1, E2, F1, F2] 
Eruptive Stage 1 (0 to $11 \mathrm{ka})$

bla

$\operatorname{trg}$

bcef

bdu

bdw

bnof

Basalt of Al Labah (Holocene) - 'A'ā and pāhoehoe alkalic and tholeiitic basalt (46.4-46.9\% $\mathrm{SiO}_{2}$; $0.32-1.01 \% \mathrm{~K}_{2} \mathrm{O}$ ) lava flows, very rough relief; well-defined pressure ridges, channels, levees, and inflated surfaces; associated 2.2-km-long, elongate fissure vent has seven scoria cones and craters that have spatter ramparts. Contains phenocrysts of plagioclase $(<1 \%, \leq 2 \mathrm{~mm})$ and olivine $(<1 \%, \leq 5 \mathrm{~mm})$. Exposed over $60.7 \mathrm{~km}^{2}$; lava flows reach $22.8 \mathrm{~km}$ from vent. See Camp and others (1987) for detailed discussion of geochemical variations and emplacement of unit; see Kawabata and others (2015) for description of unit's air-fall-tephra deposit. Overlies units bdw (25.6 $\pm 16.2 \mathrm{ka})$, bdy $(139.2 \pm 11.3 \mathrm{ka})$, blsa $(346.9 \pm 9.9 \mathrm{ka})$, bmat $(136.7 \pm 7.6 \mathrm{ka})$, bnof $(24.4 \pm 1.3$ ka), bpr (378.8 $\pm 10.0 \mathrm{ka})$, bsu (85.7 $\pm 5.7 \mathrm{ka})$, buqa $(1,069.6 \pm 19.3 \mathrm{ka}), \mathrm{hma}(220.5 \pm 10.9 \mathrm{ka})$, mh11, and Qbra (2,140.0 $\pm 26.0 \mathrm{ka})$. Historically documented age, 1256 C.E. [A1, B1]

Trachyte of Um Rgaibah (Holocene) - Trachyte (62.5-62.9\% $\left.\mathrm{SiO}_{2} ; 5.17-5.31 \% \mathrm{~K}_{2} \mathrm{O}\right)$ lava dome and pyroclastic-flow deposits. Contains phenocrysts of K-rich feldspars (anorthoclase and sanidine) (together, $<1 \%, \leq 1 \mathrm{~mm}$ ) and clinopyroxene $(\leq 1 \%, \leq 1 \mathrm{~mm})$ within abundant, poorly inflated juvenile clasts. Erupted from partly exposed crater, followed by emplacement of $0.6-\mathrm{km}$-diameter lava dome that has lava spine preserved at its summit. Exposed over $11.8 \mathrm{~km}^{2}$; pyroclastic-flow deposits reach at least $3.9 \mathrm{~km}$ from source. Owing to their young age, pyroclastic-flow deposits are relatively continuous, but erosion has resulted in a few disconnected outcrops. Overlies units $\mathrm{mz}$, tef $(88.0 \pm 1.8 \mathrm{ka})$, tg4 $(84.3 \pm 1.6 \mathrm{ka})$, and tg5 $(79.7 \pm 1.6 \mathrm{ka}) .{ }^{40} \mathrm{Ar} /{ }^{39} \mathrm{Ar}$ age, $4.2 \pm 5.2 \mathrm{ka}$. On the basis of its uncertainty, unit age could be Holocene or late Pleistocene [E2]

Eruptive Stage 2 (11 to $45 \mathrm{ka}$ )

Basalt of Central Finger (late Pleistocene) — ' $\mathrm{A}$ 'āa and pāhoehoe alkalic basalt (45.2-45.8\% $\mathrm{SiO}_{2}$; $0.74-0.87 \% \mathrm{~K}_{2} \mathrm{O}$ ) lava flows, very rough relief; well-defined pressure ridges, channels, and levees; associated 1.9-km-long, elongate fissure vent has multiple low-lying craters that have spatter ramparts. Contains phenocrysts of plagioclase $(2 \%, \leq 10 \mathrm{~mm})$ and olivine $(<1-3 \%, \leq 5$ $\mathrm{mm})$. Exposed over $18.2 \mathrm{~km}^{2}$; lava flows reach $15.0 \mathrm{~km}$ from vent. Overlies units bag $(220.3 \pm 8.3$ $\mathrm{ka})$, bhb $(246.4 \pm 25.0 \mathrm{ka})$, and bna $(162.9 \pm 11.1 \mathrm{ka})$; underlies units bnof $(24.4 \pm 1.3 \mathrm{ka})$ and bsof $(24.4 \pm 1.3 \mathrm{ka})$. Cosmogenic ${ }^{36} \mathrm{Cl}$ surface-exposure age, $29.1 \pm 3.7 \mathrm{ka}$; eruption age, $24.4 \pm 1.3 \mathrm{ka}$ (weighted mean of bcef, bnof, and bsof ages); paleomagnetic similarities support that unit is associated in time with eruptions of units bnof $(24.4 \pm 1.3 \mathrm{ka})$ and bsof $(24.4 \pm 1.3 \mathrm{ka})$ [A2, B2]

Basalt of Al Du'aythah (late Pleistocene) - Two small-volume ' $a$ 'ā alkalic basalt (45.6-46.2\% $\mathrm{SiO}_{2}$; $0.70-0.73 \% \mathrm{~K}_{2} \mathrm{O}$ ) lava flows, subdued relief; pressure ridges and four associated scoria cones. Unit is more than $7 \mathrm{~km}$ away from any other volcanic rocks that are related to northern Harrat Rahat volcanism. Contains phenocrysts of plagioclase $(<1-15 \%, \leq 10 \mathrm{~mm})$ and olivine $(<1-5 \%, \leq 2 \mathrm{~mm})$. Exposed over $0.1 \mathrm{~km}^{2}$; lava flows each reach $0.1 \mathrm{~km}$ from vents. Cosmogenic ${ }^{36} \mathrm{Cl}$ surface-exposure age, $13.3 \pm 1.9 \mathrm{ka}$. On the basis of its age uncertainty, unit age could be Holocene or late Pleistocene [A1, B1]

Basalt of Ad Duwaykhilah (late Pleistocene) - ' $A$ '‘̄a and minor pāhoehoe alkalic basalt (45.4-46.4\% $\mathrm{SiO}_{2} ; 0.38-0.80 \% \mathrm{~K}_{2} \mathrm{O}$ ) lava flows, rough relief; well-defined pressure ridges, channels, and levees; two associated scoria cones have nine craters. Contains phenocrysts of plagioclase $(\leq 1 \%, \leq 8 \mathrm{~mm})$ and olivine $(<1 \%, \leq 2 \mathrm{~mm})$. Conservative reconstruction indicates that unit is present over at least $48.6 \mathrm{~km}^{2}$; lava flows reach $16.5 \mathrm{~km}$ from vent. Overlies units bmat (136.7 $\left.\pm 7.6 \mathrm{ka}\right)$, bsu $(85.7 \pm 5.7$

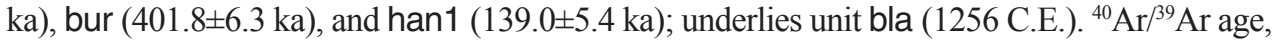
$25.6 \pm 16.2 \mathrm{ka}$. On the basis of its uncertainty, unit age could be Holocene or late Pleistocene [A1, B1]

Basalt of Northern Fingers (late Pleistocene) - ' $A$ ' $\bar{a}$ and pāhoehoe alkalic basalt (45.2-45.8\% $\mathrm{SiO}_{2} ; 0.78-0.84 \% \mathrm{~K}_{2} \mathrm{O}$ ) lava flows, rough relief; well-defined pressure ridges, channels, levees, and inflated surfaces; associated $0.7-\mathrm{km}-\mathrm{long}$, elongate scoria-cone complex has six craters. Contains phenocrysts of plagioclase $(<1-3 \%, \leq 8 \mathrm{~mm})$ and olivine $(<1-2 \%, \leq 2 \mathrm{~mm})$. Exposed over $34.5 \mathrm{~km}^{2}$; two branching lava-flow lobes, eastern and western, reach 12.2 and $12.5 \mathrm{~km}$, respectively, from vent. Overlies units bag (220.3 $\pm 8.3 \mathrm{ka})$, bcef $(24.4 \pm 1.3 \mathrm{ka})$, bdy (139.2 $\pm 11.3 \mathrm{ka})$, bh82 $(507.4 \pm 38.3 \mathrm{ka})$, bhb (246.4 $\pm 25.0 \mathrm{ka})$, blsa ( $346.9 \pm 9.9 \mathrm{ka})$, bups, bza, and hma (220.5 $\pm 10.9 \mathrm{ka})$; underlies unit bla (1256 C.E.). Cosmogenic ${ }^{36} \mathrm{Cl}$ surface-exposure age, $22.0 \pm 3.3 \mathrm{ka}$; eruption age, $24.4 \pm 1.3 \mathrm{ka}$ (weighted mean of bcef, bnof, and bsof ages); paleomagnetic similarities support that unit is associated in time with eruptions of units bcef $(24.4 \pm 1.3 \mathrm{ka})$ and bsof $(24.4 \pm 1.3 \mathrm{ka})$ [A1, A2, B1, B2] 
Basalt of Southern Fingers (late Pleistocene) - ' $A$ ' $\bar{a}$ and pāhoehoe alkalic and tholeiitic basalt (45.9-46.5\% $\left.\mathrm{SiO}_{2} ; 0.38-0.53 \% \mathrm{~K}_{2} \mathrm{O}\right)$ lava flows, very rough relief; well-defined pressure ridges, channels, and levees; associated 2.9-km-long, elongate fissure vent has multiple low-lying craters that have spatter ramparts. Contains phenocrysts of plagioclase $(1-5 \%, \leq 40$ $\mathrm{mm}$ ) and olivine $(<1-3 \%, \leq 30 \mathrm{~mm})$. Exposed over $39.6 \mathrm{~km}^{2}$; two branching lava-flow lobes, northern and southern, reach 19.1 and $15.4 \mathrm{~km}$, respectively, from vent. Overlies units bag $(220.3 \pm 8.3 \mathrm{ka})$, bcef $(24.4 \pm 1.3 \mathrm{ka})$, bh10 (137.3 $\pm 11.3 \mathrm{ka})$, bhb $(246.4 \pm 25.0 \mathrm{ka})$, bli, bni $(402.5 \pm 15.4 \mathrm{ka})$, buqh, busi, and hlh $(154.8 \pm 5.5 \mathrm{ka})$. Cosmogenic ${ }^{36} \mathrm{Cl}$ surface-exposure ages, $21.4 \pm 2.3 \mathrm{ka}, 26.0 \pm 3.0 \mathrm{ka}, 26.4 \pm 2.9 \mathrm{ka}$; eruption age, $24.4 \pm 1.3 \mathrm{ka}$ (weighted mean of bcef, bnof, and bsof ages); paleomagnetic similarities support that unit is associated in time with eruptions of units bcef $(24.4 \pm 1.3 \mathrm{ka})$ and bnof $(24.4 \pm 1.3 \mathrm{ka})$ [B2, C2]

Hawaiite of Khamisah (late Pleistocene) - ' $A$ '‘a and minor pāhoehoe hawaiite (49.0\% $\mathrm{SiO}_{2} ; 1.45 \%$ $\mathrm{K}_{2} \mathrm{O}$ ) lava flows, rough to moderate relief; well-defined pressure ridges, channels, and levees; associated, partly collapsed scoria cone. Aphyric. Exposed over $25.3 \mathrm{~km}^{2}$; lava flows reach 12.4 $\mathrm{km}$ from vent. Overlies all surrounding volcanic units, which are unmapped and unnamed in

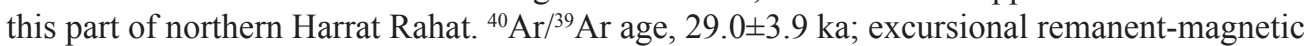
direction indicates that unit erupted during Mono Lake excursion [F2]

Trachyte of Dabaa 1 (late Pleistocene) - Trachyte (62.9-64.6\% $\left.\mathrm{SiO}_{2} ; 4.20-4.59 \% \mathrm{~K}_{2} \mathrm{O}\right)$ lava dome, surrounding block-and-ash flow, and proximal air-fall-tephra deposit. Contains phenocrysts of K-rich feldspar (anorthoclase and sanidine) (together, 10\%, $\leq 1 \mathrm{~mm}$ ) within abundant, dense juvenile clasts. During lava-dome emplacement, underlying units bd1 (717.7 $\pm 12.2 \mathrm{ka})$ and $\mathrm{md} 1$ $(116.7 \pm 2.8 \mathrm{ka})$ were uplifted and are exposed around periphery of lava dome. Exposed over $1.9 \mathrm{~km}^{2}$; block-and-ash-flow deposits reach at least $0.9 \mathrm{~km}$ from lava dome. Overlies units bd1 $(717.7 \pm 12.2 \mathrm{ka})$, bsas $(115.3 \pm 7.5 \mathrm{ka}), \mathrm{md} 1$ (116.7 $\pm 2.8 \mathrm{ka})$, and oju (424.2 $\pm 1.8 \mathrm{ka}, 437.6 \pm 4.3 \mathrm{ka})$. ${ }^{40} \mathrm{Ar}{ }^{\beta 9} \mathrm{Ar}$ ages, $16.9 \pm 2.9 \mathrm{ka}, 18.1 \pm 2.4 \mathrm{ka}$; eruption age, $17.6 \pm 1.8 \mathrm{ka}$ (weighted mean age) [D2] dome and pyroclastic-flow deposits. Contains phenocrysts of K-rich feldspar (anorthoclase and sanidine) (together, $<1-5 \%, \leq 2 \mathrm{~mm}$ ) within abundant, poorly inflated juvenile clasts. Erupted from partly exposed crater, followed by emplacement of $0.8-\mathrm{km}$-diameter lava dome that has smaller, 0.2-km-diameter crater near its summit; lava-dome extrusion resulted in uplift of unit hmo $(239.0 \pm 4.1 \mathrm{ka})$. Exposed over $3.1 \mathrm{~km}^{2}$; pyroclastic-flow deposits reach at least 2.5 $\mathrm{km}$ from source. Small, disconnected outcrops of pyroclastic-flow deposits are preserved in low-lying areas between taller pressure ridges of lava, tumuli, and hummocky terrain, located

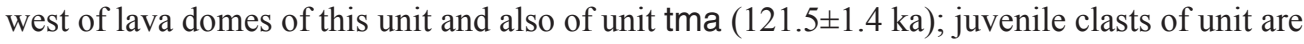
visually similar to those of unit tma $(121.5 \pm 1.4 \mathrm{ka})$ and are most easily distinguished using geochemical differences. Overlies units bm2, bmt, hmo (239.0 $44.1 \mathrm{ka}), \mathrm{mma}(154.0 \pm 8.3 \mathrm{ka})$, oba (242.8 $\pm 2.4 \mathrm{ka})$, and tma (121.5 $\pm 1.4 \mathrm{ka}) .{ }^{40} \mathrm{Ar} /{ }^{39} \mathrm{Ar}$ age, $31.9 \pm 2.1 \mathrm{ka}$ [D2] pyroclastic-flow deposits. Sourced from $0.4-\mathrm{km}$-diameter crater. Contains phenocrysts of K-rich feldspars (anorthoclase and sanidine) (together, $1 \%, \leq 1 \mathrm{~mm}$ ) and clinopyroxene (aegirine and augite) (together, $\leq 1 \%, \leq 1 \mathrm{~mm}$ ) within abundant, poorly inflated juvenile clasts. Exposed over more than $13.7 \mathrm{~km}^{2}$; pyroclastic-flow deposits reach at least $3.7 \mathrm{~km}$ from source. Owing to easily erodible nature of unit, margins of unit contain many isolated outcrops of pyroclastic-flow deposits. Presence of many older lava flows underlying unit as isolated outcrops is due to erosion removal of unit's pyroclastic-flow deposits. Overlies units bahu, basu (453.4 $\pm 12.8 \mathrm{ka})$, bawa, bnj, bqar, bsj, bssu $(313.9 \pm 11.3 \mathrm{ka})$, and buru. ${ }^{40} \mathrm{Ar} /{ }^{39} \mathrm{Ar}$ ages, $35.9 \pm 2.7 \mathrm{ka}, 41.0 \pm 2.0 \mathrm{ka}$; eruption age, $39.2 \pm 1.6 \mathrm{ka}$ (weighted mean age) [F2]

\section{Eruptive Stage 3 (45 to $70 \mathrm{ka}$ )}

Basalt of Musawda'ah (late Pleistocene) - 'A'āa and pāhoehoe alkalic basalt and hawaiite (45.4$47.7 \% \mathrm{SiO}_{2} ; 1.00-1.38 \% \mathrm{~K}_{2} \mathrm{O}$ ) lava flows, very rough relief; well-defined pressure ridges, channels, and levees; associated scoria cone and spatter ramparts. Contains phenocrysts of plagioclase $(2-5 \%, \leq 50 \mathrm{~mm})$ and olivine $(1 \%, \leq 3 \mathrm{~mm})$. Exposed over $86.6 \mathrm{~km}^{2}$; two branching lava-flow lobes, northern and southern, reach 26.7 and $11.8 \mathrm{~km}$, respectively, from vent. Overlies units

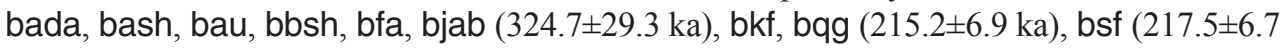
ka), bsk, bsy (236.2 $\pm 29.2 \mathrm{ka})$, bwm, and bzi; flowed around older unit mma (154.0 18.3 $\mathrm{ka}$ ); underlies unit han3 $(51.0 \pm 9.0 \mathrm{ka})$. Cosmogenic ${ }^{36} \mathrm{Cl}$ surface-exposure ages, $56.5 \pm 6.7 \mathrm{ka}$, $66.0 \pm 11.0 \mathrm{ka}$; eruption age, $59.1 \pm 5.7 \mathrm{ka}$ (weighted mean age) [C1, C2, D1, D2] 
Hawaiite of Al Anahi 3 (late Pleistocene) - 'A'ā and pāhoehoe alkalic basalt and hawaiite $\left(46.7-48.9 \% \mathrm{SiO}_{2} ; 0.92-1.50 \% \mathrm{~K}_{2} \mathrm{O}\right)$ lava flows, very rough relief; associated scoria cone has two craters. Contains phenocrysts of plagioclase $(1 \%, \leq 10 \mathrm{~mm})$ and olivine $(\leq 1 \%, \leq 4 \mathrm{~mm})$. Exposed over $68.7 \mathrm{~km}^{2}$; three branching lava-flow lobes, northern, middle, and southern, reach 19.7, 14.2, and $14.9 \mathrm{~km}$, respectively, from vent. Overlies units bh89 (1,014.0 $14.0 \mathrm{ka})$, bjs, bkf, bmg (570.0 $\pm 5.9 \mathrm{ka})$, bms $(59.1 \pm 5.7 \mathrm{ka})$, bmz, bqg (215.2 $\pm 6.9 \mathrm{ka})$, bsb, bsh $(191.5 \pm 4.2$

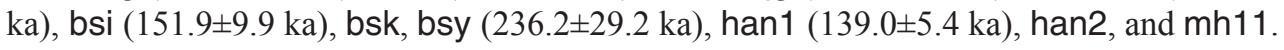

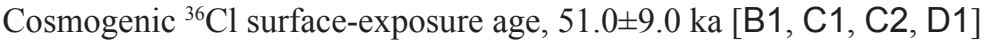

Eruptive Stage 4 (70 to $100 \mathrm{ka}$ )

bsk

bsu

han2

mh11

tef

Basalt of Sha'ib Al Khakh (late Pleistocene) - 'A'āa and pāhoehoe alkalic basalt (46.3-47.1\% $\mathrm{SiO}_{2} ; 0.93-1.19 \% \mathrm{~K}_{2} \mathrm{O}$ ) lava flows, very rough relief; well-defined pressure ridges, channels, levees, and inflated surfaces; two associated elongate (0.2- and 0.6-km-long) scoria cones. Contains phenocrysts of plagioclase $(<1 \%, \leq 4 \mathrm{~mm})$ and olivine $(2-3 \%, \leq 1 \mathrm{~mm})$. Conservative reconstruction indicates that unit is present over at least $53.6 \mathrm{~km}^{2}$; two branching lava-flow lobes, northern and southern, reach at least $14.6 \mathrm{~km}$ and at least $11.8 \mathrm{~km}$, respectively, from vent. Overlies units bau, bhc, bhu (285.1 $\pm 6.6 \mathrm{ka})$, bjs, bkf, bmg $(570.0 \pm 5.9 \mathrm{ka})$, bsq, and bun $(105.0 \pm 8.6 \mathrm{ka})$; underlies units bms $(59.1 \pm 5.7 \mathrm{ka})$ and han3 (51.0 $\pm 9.0 \mathrm{ka})$. Paleomagnetic similarities indicate that unit correlates in time with eruption of part of unit mh11 [B1, C1]

Basalt of As Suddiyah (late Pleistocene) - 'A'ā and pāhoehoe alkalic basalt (45.7-46.1\% $\mathrm{SiO}_{2}$; $0.64-0.75 \% \mathrm{~K}_{2} \mathrm{O}$ ) lava flows, very subdued relief; associated 1.4-km-long, elongate scoria-cone complex has 14 craters. Contains phenocrysts of plagioclase $(<1-2 \%, \leq 10 \mathrm{~mm})$ and olivine $(2-4 \%$, $\leq 5 \mathrm{~mm}$ ). Conservative reconstruction indicates that unit is present over at least $26.8 \mathrm{~km}^{2}$; lava flows reach $9.5 \mathrm{~km}$ from vent. Overlies units bha, bis, bra, bur (401.8 $\pm 6.3 \mathrm{ka})$, and han1 (139.0 $\pm 5.4 \mathrm{ka})$;

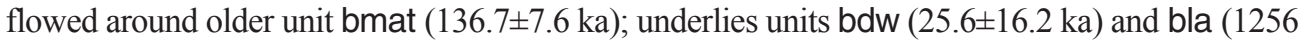
C.E.). ${ }^{40} \mathrm{Ar}{ }^{39} \mathrm{Ar}$ ages, $84.3 \pm 8.6 \mathrm{ka}, 86.8 \pm 7.6 \mathrm{ka}$; eruption age, $85.7 \pm 5.7 \mathrm{ka}$ (weighted mean age) [A1]

Hawaiite of Al Anahi 2 (late Pleistocene) - ' $\mathrm{A}$ 'ā and minor pāhoehoe hawaiite (47.1-47.3\% $\mathrm{SiO}_{2}$; $1.42-1.47 \% \mathrm{~K}_{2} \mathrm{O}$ ) lava flows, very rough relief; well-defined pressure ridges, channels, levees, and inflated surfaces; associated scoria cone. Contains phenocrysts of plagioclase $(<1 \%, \leq 10$ $\mathrm{mm})$ and olivine $(1 \%, \leq 2 \mathrm{~mm})$. Conservative reconstruction indicates that unit is present over at least $25.4 \mathrm{~km}^{2}$; lava flows reach $12.4 \mathrm{~km}$ from vent. Overlies units bmat (136.7 $\left.\pm 7.6 \mathrm{ka}\right), \mathrm{bmz}$, and bsb; underlies units han3 (51.0 $9.0 \mathrm{ka})$ and mh11 [B1, C1]

Mugearite of Hill 1125 (late Pleistocene) - ' $A$ ' $a \bar{a}$ and pāhoehoe hawaiite and mugearite (48.0$49.0 \% \mathrm{SiO}_{2} ; 1.72-1.76 \% \mathrm{~K}_{2} \mathrm{O}$ ) lava flows, very rough relief; well-defined pressure ridges, channels, levees, and inflated surfaces; associated scoria cone. Contains olivine phenocrysts $(<1 \%, \leq 1 \mathrm{~mm})$. Conservative reconstruction indicates that unit is present over at least $45.6 \mathrm{~km}^{2}$; lava flows reach $19.3 \mathrm{~km}$ from vent. Overlies units bam2, bam4, bdy (139.2 $\pm 11.3 \mathrm{ka})$, bh10

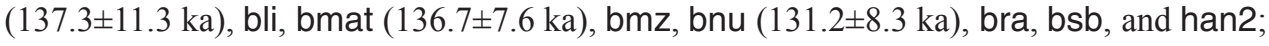
underlies units bla (1256 C.E.), bsof (24.4 $\pm 1.3 \mathrm{ka})$, and han3 (51.0 $\pm 9.0 \mathrm{ka})$. Paleomagnetic studies reveal at least two remanent-magnetic directions for unit, one of which correlates in time with eruption of unit bsk [B1, C1, C2]

Trachyte of Al Efairia (late Pleistocene) - Trachyte (62.9-63.7\% $\mathrm{SiO}_{2} ; 4.93-5.31 \% \mathrm{~K}_{2} \mathrm{O}$ ) pyroclasticflow and -surge deposits. Sourced from two craters (outer crater, $1.8 \mathrm{~km}$ diameter; inner crater, $0.8 \mathrm{~km}$ diameter). Contains phenocrysts of K-rich feldspars (anorthoclase and sanidine) (together, $1-10 \%, \leq 4 \mathrm{~mm}$ ) and clinopyroxene (augite and minor amounts of aegirine) (together, $<1-10 \%, \leq 1$ $\mathrm{mm}$ ) within abundant, poorly inflated juvenile clasts. Lithic clasts include previously erupted basalt to benmoreite lavas and Precambrian rocks. Conservative reconstruction indicates that unit is present over at least $66.8 \mathrm{~km}^{2}$; pyroclastic-flow deposits reach at least $9.0 \mathrm{~km}$ from source. Most widespread pyroclastic-flow deposit in northern Harrat Rahat; also encompasses many small, isolated outcrops around its margins owing to its easily erodible nature. Juvenile clasts of unit are visually similar to, but petrographically and geochemically distinct from, those of overlying pyroclastic-flow deposits of units tg4 (84.3 $\pm 1.6 \mathrm{ka}), \operatorname{tg} 5(79.7 \pm 1.6 \mathrm{ka})$, and trg $(4.2 \pm 5.2 \mathrm{ka})$; outcrops also have distinctive yellow color compared to tan color of unit tg4 $(84.3 \pm 1.6 \mathrm{ka})$, green color of unit tg5 $(79.7 \pm 1.6 \mathrm{ka})$, and brown color of unit trg (4.2 $\pm 5.2 \mathrm{ka})$. Overlies units bd3 (307.7 $\pm 4.6 \mathrm{ka})$, bef, bjn (512.8 \pm 9.3 ka), bqar, brg (543.3 $\pm 5.6 \mathrm{ka})$, hhil (490.1 $\pm 4.6 \mathrm{ka}), \mathrm{hmk}(248.2 \pm 8.3 \mathrm{ka})$, masu $(252.2 \pm 2.7 \mathrm{ka})$,

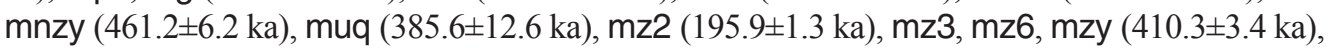

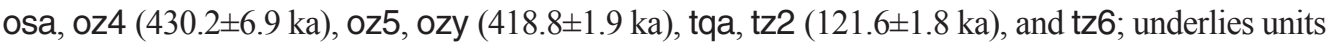
$\operatorname{tg} 4(84.3 \pm 1.6 \mathrm{ka}), \operatorname{tg} 5(79.7 \pm 1.6 \mathrm{ka})$, and $\operatorname{trg}(4.2 \pm 5.2 \mathrm{ka}) .{ }^{40} \mathrm{Ar} /{ }^{39} \mathrm{Ar}$ ages, $72.3 \pm 2.8 \mathrm{ka}, 83.7 \pm 1.6$ 
ka, $86.5 \pm 8.7 \mathrm{ka}, 86.9 \pm 1.9 \mathrm{ka}, 90.9 \pm 1.9 \mathrm{ka}, 93.1 \pm 2.1 \mathrm{ka}$; eruption age, $88.0 \pm 1.8 \mathrm{ka}$ (weighted mean, calculated using five of six ages [excluding $72.3 \pm 2.8 \mathrm{ka}]$ ] [E2, F2]

Trachyte of Gura 2 (late Pleistocene) - Two trachyte (61.0-63.0\% $\mathrm{SiO}_{2} ; 4.95-5.12 \% \mathrm{~K}_{2} \mathrm{O}$ )

pyroclastic-flow deposits. Sourced from two nested craters ( 0.6 and $0.8 \mathrm{~km}$ diameter); craters are in high-standing area that represents lava-dome emplacement prior to explosive eruptive phases. Contains phenocrysts of K-rich feldspars (anorthoclase and sanidine) (together, $1-50 \%, \leq 3 \mathrm{~mm}$ ) and clinopyroxene (augite and minor amounts of aegirine) (together, $1 \%, \leq 2$ $\mathrm{mm}$ ) within abundant, poorly inflated juvenile clasts. Exposed over $6.9 \mathrm{~km}^{2}$; pyroclastic-flow deposits reach at least $3.0 \mathrm{~km}$ from source. Unit contains small, disconnected outcrops around its margins owing to its easily erodible nature; these outcrops tend to be in low-lying areas within high-standing tumuli from older, underlying lava flows. Juvenile clasts from unit are petrographically similar to those from units tg3 $(142.4 \pm 2.2 \mathrm{ka})$ and tmo $(31.9 \pm 2.1 \mathrm{ka})$, but they are geochemically distinct. Overlies units bd1 $(717.7 \pm 12.2 \mathrm{ka})$, bda $(223.0 \pm 18.9 \mathrm{ka}), \mathrm{bg} 1$, bg3 (1,112.1 $\pm 17.6 \mathrm{ka})$, bya, md1 (116.7 $\pm 2.8 \mathrm{ka}), \mathrm{mma}(154.0 \pm 8.3 \mathrm{ka})$, og2 $(128.2 \pm 4.2 \mathrm{ka})$, og3 (558.7 $\pm 4.8 \mathrm{ka})$, oju $(424.2 \pm 1.8 \mathrm{ka}, 437.6 \pm 4.3 \mathrm{ka})$, and tg3 $(142.4 \pm 2.2 \mathrm{ka}) .{ }^{40} \mathrm{Ar}{ }^{/ 39} \mathrm{Ar}$ ages, $92.9 \pm 4.1 \mathrm{ka}, 93.8 \pm 3.1 \mathrm{ka}, 94.9 \pm 4.2 \mathrm{ka}$; eruption age, $93.8 \pm 2.1 \mathrm{ka}$ (weighted mean age) [D2]

Trachyte of Gura 4 (late Pleistocene) - Trachyte $\left(63.1-64.8 \% \mathrm{SiO}_{2} ; 4.55-4.78 \% \mathrm{~K}_{2} \mathrm{O}\right)$ pyroclasticflow deposits and minor near-source air-fall-tephra deposits. Sourced from 0.5 -km-diameter crater. Contains phenocrysts of K-rich feldspars (anorthoclase and sanidine) (together, $1-40 \%, \leq 10 \mathrm{~mm}$ ) and clinopyroxene (aegirine and augite) (together, $\leq 1 \%, \leq 1 \mathrm{~mm}$ ) within abundant, poorly to moderately inflated juvenile clasts. Lithic clasts include previously erupted basalt to benmoreite lavas. Conservative reconstruction indicates that unit is present over at least $18.2 \mathrm{~km}^{2}$; pyroclastic-flow deposits reach at least $5.5 \mathrm{~km}$ from source. Widespread pyroclastic-flow deposit contains many small, disconnected outcrops around its margins owing to its easily erodible nature. Juvenile clasts of unit are petrographically and geochemically distinct from those of units tef ( $88.0 \pm 1.8 \mathrm{ka})$ and trg $(4.2 \pm 5.2 \mathrm{ka})$, but they are indistinguishable from those of unit tg5 (79.7 $\pm 1.6 \mathrm{ka})$; unit does have tan color, compared to green color of unit tg5 (79.7 $\pm 1.6 \mathrm{ka})$, yellow color of unit tef $(88.0 \pm 1.8 \mathrm{ka})$, and brown color of unit trg $(4.2 \pm 5.2 \mathrm{ka})$. Overlies units bd3 (307.7 $\pm 4.6 \mathrm{ka})$, bjn $(512.8 \pm 9.3 \mathrm{ka})$, bsd

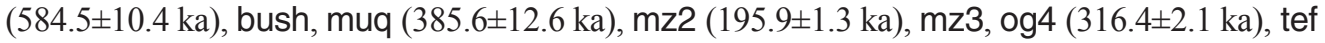
$(88.0 \pm 1.8 \mathrm{ka}), \mathrm{tz} 1(269.1 \pm 5.0 \mathrm{ka})$, and tz2 $(121.6 \pm 1.8 \mathrm{ka})$; underlies units tg5 $(79.7 \pm 1.6 \mathrm{ka})$ and $\operatorname{trg}(4.2 \pm 5.2 \mathrm{ka}) .{ }^{40} \mathrm{Ar}{ }^{\beta 9} \mathrm{Ar}$ ages, $64.0 \pm 3.1 \mathrm{ka}, 84.0 \pm 1.8 \mathrm{ka}, 85.7 \pm 4.1 \mathrm{ka}$; eruption age, $84.3 \pm 1.6 \mathrm{ka}$ (weighted mean age, calculated using two of three ages [excluding $64.0 \pm 3.1 \mathrm{ka}$ ]); paleomagnetic similarities indicate that unit correlates in time with eruption of unit tg5 $(79.7 \pm 1.6 \mathrm{ka})$ [D2, E2] flow deposits. Sourced from $0.2-\mathrm{km}$-diameter crater. Contains phenocrysts of K-rich feldspar (anorthoclase and sanidine) (together, 5-20\%, $\leq 2 \mathrm{~mm}$ ) within abundant, poorly to moderately inflated juvenile clasts. Exposed over $1.7 \mathrm{~km}^{2}$; pyroclastic-flow deposits reach $0.8 \mathrm{~km}$ northeast and $1.7 \mathrm{~km}$ southwest from source. Cryptodome $(0.3 \mathrm{~km}$ diameter $)$ has uplifted part of unit. Juvenile clasts of unit are petrographically and geochemically distinct from those of units tef

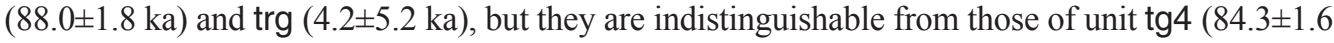
$\mathrm{ka})$. Unit does have green color, compared to tan color of unit tg4 ( $84.3 \pm 1.6 \mathrm{ka})$, yellow color of unit tef $(88.0 \pm 1.8 \mathrm{ka})$, and brown color of unit trg $(4.2 \pm 5.2 \mathrm{ka})$. Overlies units tef $(88.0 \pm 1.8 \mathrm{ka})$ and tg4 $(84.3 \pm 1.6 \mathrm{ka})$; underlies unit trg $(4.2 \pm 5.2 \mathrm{ka}) .{ }^{40} \mathrm{Ar} /{ }^{39} \mathrm{Ar}$ ages, $79.2 \pm 1.8 \mathrm{ka}, 81.5 \pm 3.7 \mathrm{ka}$, $86.3 \pm 13.2 \mathrm{ka}$; eruption age, $79.7 \pm 1.6 \mathrm{ka}$ (weighted mean age); paleomagnetic similarities indicate that unit correlates in time with eruption of unit tg4 (84.3 $\pm 1.6 \mathrm{ka})$ [E2]

\section{Eruptive Stage 5 (100 to $180 \mathrm{ka}$ )}

Basalt of Abu Rimthah (late Pleistocene) - 'A'ā and pāhoehoe alkalic basalt (46.5-47.3\% $\mathrm{SiO}_{2}$; $0.91-0.93 \% \mathrm{~K}_{2} \mathrm{O}$ ) lava flows, moderately rough relief; associated partly collapsed scoria cone. Contains phenocrysts of plagioclase $(1-5 \%, \leq 5 \mathrm{~mm})$ and olivine $(1-3 \%, \leq 4 \mathrm{~mm})$. Exposed over $11.6 \mathrm{~km}^{2}$; lava flows reach $10.8 \mathrm{~km}$ from vent. Overlies units bay, bjb, bnar, burr $(366.4 \pm 9.3$ ka), bwar, and hlh (154.8 $\pm 5.5 \mathrm{ka}) .{ }^{40} \mathrm{Ar} /{ }^{39} \mathrm{Ar}$ age, $130.3 \pm 5.0 \mathrm{ka}$. On the basis of its uncertainty, unit age could be late or middle Pleistocene [C2]

Basalt of Ad Dubaysiyah (middle Pleistocene) - Pāhoehoe and minor 'a'ā alkalic basalt (47.0\% $\mathrm{SiO}_{2} ; 0.86 \% \mathrm{~K}_{2} \mathrm{O}$ ) lava flows, subdued relief; well-defined pressure ridges, channels, levees, and inflated surfaces; associated vent complex is 3.4-km-long fissure that has single scoria cone and 14 low-lying craters and spatter ramparts. Contains olivine phenocrysts $(5-7 \%, \leq 3$ $\mathrm{mm}$ ). Exposed over $20.9 \mathrm{~km}^{2}$; lava flows reach at least $9.7 \mathrm{~km}$ from vent. Overlies units bag 
(220.3 $\pm 8.3 \mathrm{ka})$ and hma (220.5 $\pm 10.9 \mathrm{ka})$; underlies units bla (1256 C.E.), bnof ( $24.4 \pm 1.3 \mathrm{ka})$, and $\mathrm{mh} 11 .{ }^{40} \mathrm{Ar} /{ }^{39} \mathrm{Ar}$ age, $139.2 \pm 11.3 \mathrm{ka}[\mathrm{B} 1, \mathrm{~B} 2, \mathrm{C} 1, \mathrm{C} 2]$

Basalt of Hill 1066 (middle Pleistocene) - Pāhoehoe and 'a'ā alkalic basalt (46.0-46.4\% $\mathrm{SiO}_{2}$; $0.50-0.68 \% \mathrm{~K}_{2} \mathrm{O}$ ) lava flows, very rough relief; well-defined pressure ridges, channels, and levees; associated vent complex has seven craters and spatter ramparts. Contains phenocrysts of plagioclase $(<1-2 \%, \leq 15 \mathrm{~mm})$ and olivine $(1-5 \%, \leq 4 \mathrm{~mm})$. Exposed over $26.3 \mathrm{~km}^{2}$; lava flows reach $15.6 \mathrm{~km}$ from vent. Overlies units bli and buqh; underlies units bsof (24.4 $\pm 1.3 \mathrm{ka})$ and mh11. ${ }^{40} \mathrm{Ar} r{ }^{39} \mathrm{Ar}$ age, $137.3 \pm 11.3 \mathrm{ka}$; paleomagnetic similarities indicate that unit correlates in time with eruption of unit bsi (151.9 $\pm 9.9 \mathrm{ka})$ [B2, C2]

bjb Basalt of Al Janubi (middle Pleistocene)—Pāhoehoe and minor 'a'ā alkalic basalt (46.3-48.1\% $\mathrm{SiO}_{2} ; 0.80-0.93 \% \mathrm{~K}_{2} \mathrm{O}$ ) lava flows, subdued relief. Aphyric. Exposed over $3.8 \mathrm{~km}^{2}$; lava flows reach at least $9.7 \mathrm{~km}$ from vent. Overlies units burr $(366.4 \pm 9.3 \mathrm{ka})$ and bwar; underlies units bar $(130.3 \pm 5.0 \mathrm{ka})$, bsas $(115.3 \pm 7.5 \mathrm{ka}), \mathrm{md} 1(116.7 \pm 2.8 \mathrm{ka})$, and mma (154.0 $\pm 8.3 \mathrm{ka})$ [C2, D2]

Basalt of Al Khanaq (middle Pleistocene) —Pāhoehoe and 'a'ā alkalic basalt (46.0\% $\mathrm{SiO}_{2} ; 0.53 \%$ $\mathrm{K}_{2} \mathrm{O}$ ) lava flows, subdued relief. Contains phenocrysts of plagioclase $(1-2 \%, \leq 3 \mathrm{~mm})$ and olivine $(5-7 \% \leq 2 \mathrm{~mm})$. Exposed over $5.0 \mathrm{~km}^{2}$; lava flows reach at least $4.8 \mathrm{~km}$ from vent. Overlies unit blqa (196.9 $\pm 10.3 \mathrm{ka})$; flowed around older unit bsl; underlies unit bna $(162.9 \pm 11.1 \mathrm{ka})$. ${ }^{40} \mathrm{Ar} /{ }^{39} \mathrm{Ar}$ age, $144.6 \pm 19.6 \mathrm{ka}[\mathrm{A} 1, \mathrm{~A} 2]$

bm2

bmat

bmz

bna

bnar

bns

bnu

bra

Basalt of Al Malsaa 2 (middle Pleistocene) - Alkalic basalt (48.0\% $\left.\mathrm{SiO}_{2} ; 1.18 \% \mathrm{~K}_{2} \mathrm{O}\right)$. Source is scoria cone that has two craters. Aphyric. Exposed over $1.7 \mathrm{~km}^{2}$. Overlies units bm1 $(230.7 \pm 4.4 \mathrm{ka})$ and oba $(242.8 \pm 2.4 \mathrm{ka})$; underlies units $\mathrm{hm} 3$ and tmo $(31.9 \pm 2.1 \mathrm{ka})$ [D2]

Basalt of Mahd Adh Thahab Road (middle Pleistocene) - 'A'ā and pāhoehoe alkalic basalt (46.7-47.0\% $\left.\mathrm{SiO}_{2} ; 0.51-0.61 \% \mathrm{~K}_{2} \mathrm{O}\right)$ lava flows, very rough relief; well-defined pressure ridges, channels, levees, and inflated surfaces; associated collapsed scoria-cone complex. Contains phenocrysts of plagioclase $(<1 \%, \leq 10 \mathrm{~mm})$ and olivine $(2-5 \%, \leq 9 \mathrm{~mm})$. Exposed over $13.9 \mathrm{~km}^{2}$; lava flows reach at least $7.7 \mathrm{~km}$ from vent. Overlies units bmz, bru, and han1 (139.0 $\pm 5.4 \mathrm{ka})$; underlies units bdw (25.6 $\pm 16.2 \mathrm{ka})$, bla (1256 C.E.), han2, and mh11; younger unit bsu $(85.7 \pm 5.7 \mathrm{ka})$ flowed around this unit. ${ }^{40} \mathrm{Ar} /{ }^{39} \mathrm{Ar}$ age, $136.7 \pm 7.6 \mathrm{ka}[\mathrm{A} 1, \mathrm{~B} 1]$

Basalt of Al Muzayyin (middle Pleistocene) - 'A' $\bar{a}$ and pāhoehoe alkalic basalt (45.7-46.9\% $\mathrm{SiO}_{2}$; $0.69-0.98 \% \mathrm{~K}_{2} \mathrm{O}$ ) lava flows, subdued relief; inflated surfaces; associated scoria-cone and spatter-rampart vent complex. Contains phenocrysts of plagioclase $(<1 \%, \leq 5 \mathrm{~mm})$ and olivine $(1-2 \%, \leq 4 \mathrm{~mm})$. Conservative reconstruction indicates that unit is present over at least $6.9 \mathrm{~km}^{2}$; lava flows reach at least $6.2 \mathrm{~km}$ from vent. Overlies units bra and bru; underlies units bmat

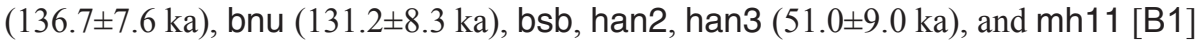

Basalt of Nabta (middle Pleistocene) — 'A'āa and pāhoehoe alkalic basalt (46.9-47.4\% $\mathrm{SiO}_{2}$; 0.67$0.82 \% \mathrm{~K}_{2} \mathrm{O}$ ) lava flows, moderately rough relief; associated 0.8 -km-long, elongate scoria-cone complex has five craters. Contains phenocrysts of plagioclase $(<1-3 \%, \leq 7 \mathrm{~mm})$ and olivine $(1-5 \%$, $\leq 8 \mathrm{~mm}$ ). Exposed over $21.8 \mathrm{~km}^{2}$; lava flows reach $18.6 \mathrm{~km}$ from vent. Overlies units bbr, bh82 $(507.4 \pm 38.3 \mathrm{ka})$, bka (144.6 $\pm 19.6 \mathrm{ka})$, blqa $(196.9 \pm 10.3 \mathrm{ka})$, and bsl; flowed around margin of older unit bag (220.3 $\pm 8.3 \mathrm{ka})$; underlies unit bcef $(24.4 \pm 1.3 \mathrm{ka}) .{ }^{40} \mathrm{Ar} /{ }^{39} \mathrm{Ar}$ age: $162.9 \pm 11.1 \mathrm{ka}$ [A2, B2]

Basalt north of Abu Rimthah (middle Pleistocene) - 'A' ${ }^{\prime} \bar{a}$ and pāhoehoe basaltic lava flows rough relief; pressure ridges and inflated surfaces; associated scoria-cone complex. Exposed over $3.4 \mathrm{~km}^{2}$; lava flows reach at least $3.3 \mathrm{~km}$ from vent. Underlies units bar $(130.3 \pm 5.0 \mathrm{ka})$, bsi $(151.9 \pm 9.9 \mathrm{ka})$, bwar, and hlh (154.8 $\pm 5.5 \mathrm{ka})$ [C2]

Basalt of Nashbah (middle Pleistocene) - 'A'āa and pāhoehoe basaltic lava flows, moderately rough relief; associated partly collapsed scoria-cone complex. Exposed over $63.5 \mathrm{~km}^{2}$; two branching lava-flow lobes, eastern and western, reach 19.5 and $24.0 \mathrm{~km}$, respectively, from vent. Overlies units bara, bhin, bme, bmk (261.3 $\pm 19.1 \mathrm{ka})$, bmuf, bsou, buru, and byid [F1, F2]

Basalt of Nubala (late Pleistocene) - 'A' ${ }^{\prime} \bar{a}$ and pāhoehoe alkalic basalt (45.7-47.6\% $\mathrm{SiO}_{2} ; 0.94$ $\left.0.99 \% \mathrm{~K}_{2} \mathrm{O}\right)$ lava flows, moderately subdued relief. Contains phenocrysts of plagioclase $(2 \%$, $\leq 9 \mathrm{~mm})$ and olivine $(<1 \%, \leq 1 \mathrm{~mm})$. Exposed over $12.6 \mathrm{~km}^{2}$; lava flows reach at least $7.5 \mathrm{~km}$ from vent. Overlies units bai $(546.2 \pm 9.6 \mathrm{ka})$, bbd $(223.4 \pm 8.6 \mathrm{ka})$, bmz, bra, brh $(411.5 \pm 5.9$

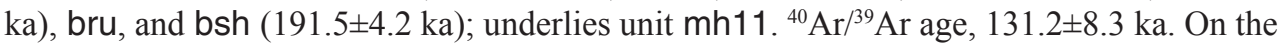
basis of its uncertainty, unit age could be late or middle Pleistocene [B1]

Basalt of Al Rafi'ah (middle Pleistocene) - 'A 'ā and pāhoehoe tholeiitic basalt (46.5-47.1\% $\mathrm{SiO}_{2}$; $0.34-0.58 \% \mathrm{~K}_{2} \mathrm{O}$ ) lava flows, very subdued relief; associated 0.8 -km-long, elongate scoria-cone complex has four craters. Contains phenocrysts of plagioclase $(<1 \%, \leq 10 \mathrm{~mm})$ and olivine $(1-10 \%$, $\leq 10 \mathrm{~mm})$. Conservative reconstruction indicates that unit is present over at least $23.5 \mathrm{~km}^{2}$; lava 
brt

bsas

bsb

bsi

bsq

bun

bwar

bwm

bza

han1

har flows reach at least $11.9 \mathrm{~km}$ from vent. Overlies units bai (546.2 $\pm 9.6 \mathrm{ka})$, bis, bqr, and bru; underlies units bmz, bnu (131.2 $\pm 8.3 \mathrm{ka})$, bsu $(85.7 \pm 5.7 \mathrm{ka})$, han1 $(139.0 \pm 5.4 \mathrm{ka})$, and mh11 [A1, B1]

Basalt of Radio Tower (middle Pleistocene) — ' $\mathrm{A}$ ' $\overline{\mathrm{a}}$ and pāhoehoe tholeiitic basalt (46.8-47.0\% $\mathrm{SiO}_{2} ; 0.38-0.40 \% \mathrm{~K}_{2} \mathrm{O}$ ) lava flows, very subdued and heavily eroded relief; associated scoriacone complex. Contains phenocrysts of plagioclase $(<1 \%, \leq 1 \mathrm{~mm})$ and olivine $(1 \%, \leq 1 \mathrm{~mm})$. Exposed over only $0.1 \mathrm{~km}^{2}$. Underlies units bwar, har, and ort [C2]

Basalt of Shai'ab Abu Sikhbir (late Pleistocene) — 'A'ā and pāhoehoe alkalic basalt (46.7-48.0\% $\mathrm{SiO}_{2} ; 0.72-0.94 \% \mathrm{~K}_{2} \mathrm{O}$ ) lava flows, rough to moderately rough relief; well-defined channels, levees, and inflated surfaces. Contains phenocrysts of plagioclase $(2-3 \%, \leq 10 \mathrm{~mm})$ and olivine $(1-7 \%, \leq 5 \mathrm{~mm})$. Exposed over $55.6 \mathrm{~km}^{2}$; two branching lava-flow lobes, northern and southern, reach 10.3 and $17.1 \mathrm{~km}$, respectively, from inferred vent area. Vent was destroyed during uplift of lava dome of unit td1 (17.6 $\pm 1.8 \mathrm{ka})$. Overlies units bay, bhy (235.1 $\pm 7.5 \mathrm{ka})$, bjb, bjg, burr (366.4 $\pm 9.3 \mathrm{ka})$, hlh (154.8 $\pm 5.5 \mathrm{ka})$, hsb, md1 (116.7 $\pm 2.8 \mathrm{ka})$, and osb (535.8 $\pm 11.8 \mathrm{ka})$; underlies unit td1 $(17.6 \pm 1.8 \mathrm{ka}) .{ }^{40} \mathrm{Ar} /{ }^{39} \mathrm{Ar}$ age, $115.3 \pm 7.5 \mathrm{ka}$; paleomagnetic similarities indicate that unit correlates in time with eruption of unit md1 (116.7 $\pm 2.8 \mathrm{ka})$ [C2, D2]

Basalt of Sha'ib Banthane (middle Pleistocene) — 'A' $a ̄ a$ and pāhoehoe alkalic basalt (45.7-46.0\% $\mathrm{SiO}_{2} ; 0.94-0.97 \% \mathrm{~K}_{2} \mathrm{O}$ ) lava flows, moderately rough relief. Contains phenocrysts of plagioclase $(1 \%, \leq 5 \mathrm{~mm})$ and olivine $(1 \%, \leq 1 \mathrm{~mm})$. Conservative reconstruction indicates that unit is present over at least $11.1 \mathrm{~km}^{2}$; lava flows reach at least $8.0 \mathrm{~km}$ from vent. Overlies units bh89 $(1,014.0 \pm 14.0 \mathrm{ka})$ and bmz; underlies units han2, han3 (51.0 $\pm 9.0 \mathrm{ka})$, and mh11 [B1, C1]

Basalt of Sha'ib Iskabah (middle Pleistocene) - 'A' $\mathrm{A}$ à and pāhoehoe alkalic basalt (45.2-46.8\% $\mathrm{SiO}_{2}$; $0.57-1.01 \% \mathrm{~K}_{2} \mathrm{O}$ ) lava flows, subdued relief; associated scoria cone. Contains phenocrysts of plagioclase $(2 \%, \leq 20 \mathrm{~mm})$ and olivine $(3-4 \%, \leq 8 \mathrm{~mm})$. Exposed over $11.8 \mathrm{~km}^{2}$; two branching lava-flow lobes, northern and western, reach 5.1 and $5.6 \mathrm{~km}$, respectively, from vent. Several ground cracks, which break lava-flow surface of northern lobe, are interpreted to have formed during eruption of unit bsof (24.4 $\pm 1.3 \mathrm{ka})$. Overlies units bam1 (252.2 $\pm 6.8 \mathrm{ka})$, bam4, bnar, and bni (402.5 \pm 15.4 ka); underlies units bwar, bwm, han3 (51.0 $\pm 9.0 \mathrm{ka})$, and mma $(154.0 \pm 8.3 \mathrm{ka}) .{ }^{40} \mathrm{Ar} /{ }^{39} \mathrm{Ar}$ ages, $138.1 \pm 17.2 \mathrm{ka}, 158.7 \pm 12.1 \mathrm{ka}$; eruption age, $151.9 \pm 9.9 \mathrm{ka}$ (weighted mean age); paleomagnetic similarities indicate that unit correlates in time with eruption of unit bh10 (137.3 $\pm 11.3 \mathrm{ka})$ [C2]

Basalt of Ash Suqayyiqah (middle Pleistocene) — ' A'ā and pāhoehoe alkalic basalt (46.3\% $\mathrm{SiO}_{2}$; $0.72 \% \mathrm{~K}_{2} \mathrm{O}$ ) lava flows, moderately subdued relief; associated $0.8-\mathrm{km}-$ long, elongate scoriacone complex has four craters. Aphyric. Exposed over $1.6 \mathrm{~km}^{2}$; lava flows reach at least $4.8 \mathrm{~km}$ from vent. Underlies units bsk and han3 (51.0 $\pm 9.0 \mathrm{ka})$ [C1]

Basalt of Umm Nathilah (late Pleistocene) - 'A' $' \bar{a}$ and pāhoehoe alkalic basalt (45.1-45.7\% $\mathrm{SiO}_{2}$; $0.89-0.93 \% \mathrm{~K}_{2} \mathrm{O}$ ) lava flows, moderately subdued relief; associated $0.9-\mathrm{km}$-long, elongate scoriacone complex has four craters. Contains phenocrysts of plagioclase $(1-2 \%, \leq 10 \mathrm{~mm})$ and olivine $(1-5 \%, \leq 7 \mathrm{~mm})$. Exposed over $19.7 \mathrm{~km}^{2}$; lava flows reach at least $4.5 \mathrm{~km}$ from vent. Overlies units bau and bhu $(285.1 \pm 6.6 \mathrm{ka})$; underlies unit bsk. ${ }^{40} \mathrm{Ar} /{ }^{39} \mathrm{Ar}$ age, $105.0 \pm 8.6 \mathrm{ka}[\mathrm{B} 1, \mathrm{C} 1]$

Basalt west of Abu Rimthah (middle Pleistocene) — Pāhoehoe and minor ' a' $\mathrm{a}$ tholeiitic basalt (46.6-47.3\% $\mathrm{SiO}_{2} ; 0.20-0.23 \% \mathrm{~K}_{2} \mathrm{O}$ ) lava flows, very subdued relief; associated eroded scoria cone. Contains olivine phenocrysts $(<1 \%, \leq 3 \mathrm{~mm})$. Exposed over $3.0 \mathrm{~km}^{2}$; lava flows reach at

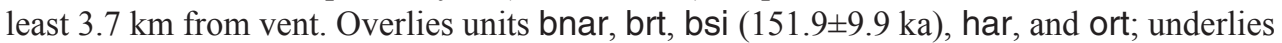
units bar (130.3 $\pm 5.0 \mathrm{ka})$, bjb, and mma (154.0 $\pm 8.3 \mathrm{ka})$ [C2]

Basalt west of Matan (middle Pleistocene) — ' $\mathrm{A}$ ' $\mathrm{a}$ and pāhoehoe alkalic basalt $\left(46.8 \% \mathrm{SiO}_{2} ; 0.77 \%\right.$ $\left.\mathrm{K}_{2} \mathrm{O}\right)$ lava flows, moderately rough relief. Contains phenocrysts of plagioclase $(<1 \%, \leq 6 \mathrm{~mm})$ and olivine $(<1 \%, \leq 2 \mathrm{~mm})$. Exposed over $3.9 \mathrm{~km}^{2}$; lava flows reach at least $7.1 \mathrm{~km}$ from vent. Overlies unit bsi (151.9 $\pm 9.9 \mathrm{ka})$; underlies units bms (59.1 $\pm 5.7 \mathrm{ka})$ and mma (154.0 $\pm 8.3 \mathrm{ka})$ [C2, D1, D2]

Basalt of Az Zanat (late Pleistocene) - ' $A$ ' $\bar{a}$ and pāhoehoe basaltic lava flows, rough relief; associated scoria cone. Exposed over $3.2 \mathrm{~km}^{2}$; lava flows reach $1.8 \mathrm{~km}$ from vent. Overlies unit hma $(220.5 \pm 10.9 \mathrm{ka})$; underlies unit bnof $(24.4 \pm 1.3 \mathrm{ka})$ [B2]

Hawaiite of Al Anahi 1 (middle Pleistocene) —Pāhoehoe hawaiite (47.1-49.1\% $\mathrm{SiO}_{2} ; 1.34-1.50 \%$ $\mathrm{K}_{2} \mathrm{O}$ ) lava flows, subdued relief; associated scoria cone has two craters. Contains phenocrysts of plagioclase $(1 \%, \leq 5 \mathrm{~mm})$ and olivine $(3 \%, \leq 1 \mathrm{~mm})$. Conservative reconstruction indicates that unit is present over at least $30.5 \mathrm{~km}^{2}$; lava flows reach $19.2 \mathrm{~km}$ from vent. Overlies units bra and bru; underlies units bdw (25.6 $\pm 16.2 \mathrm{ka})$, bmat (136.7 $\pm 7.6 \mathrm{ka})$, bsu $(85.7 \pm 5.7 \mathrm{ka})$, and han3 $(51.0 \pm 9.0 \mathrm{ka}) .{ }^{40} \mathrm{Ar} /{ }^{39} \mathrm{Ar}$ age, $139.0 \pm 5.4 \mathrm{ka}[\mathrm{A} 1, \mathrm{~B} 1, \mathrm{C} 1, \mathrm{C} 2]$

Hawaiite of Abu Rimthah (middle Pleistocene) - 'A' $\mathrm{A}$ and pāhoehoe hawaiite (47.3-48.2\% $\mathrm{SiO}_{2}$; $1.37-1.49 \% \mathrm{~K}_{2} \mathrm{O}$ ) lava flows, subdued relief; two associated scoria cones. Contains plagioclase 
hd2

hlh

$\mathrm{hm} 3$

md1

$\mathrm{mma}$

$\mathrm{mmk}$

og2

oqa

ort

$\operatorname{tg} 3$

phenocrysts $(<1 \%, \leq 10 \mathrm{~mm})$. Exposed over only $0.6 \mathrm{~km}^{2}$; lava flows reach at least $0.4 \mathrm{~km}$ from vent. Overlies units brt and ort; underlies unit bwar [C2]

Hawaiite of Dabaa 2 (late or middle Pleistocene) - ' $A$ ' $\bar{a}$ and minor pāhoehoe hawaiite (47.7-48.5\% $\left.\mathrm{SiO}_{2} ; 1.20-1.47 \% \mathrm{~K}_{2} \mathrm{O}\right)$ lava flows, rough relief; well-defined pressure ridges; associated partly collapsed scoria cone. Contains phenocrysts of plagioclase $(2-8 \%, \leq 10 \mathrm{~mm})$ and olivine $(<1-2 \%$, $\leq 5 \mathrm{~mm}$ ). Encompasses 0.8 -km-diameter cryptodome that has uplifted juvenile lava flows of unit. Exposed over $17.4 \mathrm{~km}^{2}$; lava flows reach $6.8 \mathrm{~km}$ from vent. Overlies units bas, bda $(223.0 \pm 18.9$ ka), bhm, bmy (660.4 $\pm 13.4 \mathrm{ka})$, bsm, busm, bwhu, mmu (219.6 $\pm 4.0 \mathrm{ka})$, and osa [D2, E2]

Hawaiite of Al Lihyan (middle Pleistocene) - 'A' $\bar{a}$ and pāhoehoe hawaiite and alkalic basalt $\left(47.1-49.9 \% \mathrm{SiO}_{2} ; 1.10-1.52 \% \mathrm{~K}_{2} \mathrm{O}\right)$ lava flows, very rough relief; well-defined pressure ridges, channels, and levees; associated scoria cone. Contains phenocrysts of plagioclase $(1-10 \%, \leq 5 \mathrm{~mm})$ and olivine $(\leq 1 \%, \leq 3 \mathrm{~mm})$. Exposed over $69.0 \mathrm{~km}^{2}$; two branching lava-flow lobes, northern and southern, reach 13.8 and $16.0 \mathrm{~km}$, respectively, from vent. Overlies units bay, blqh, blsl $(228.6 \pm 12.0 \mathrm{ka})$, bnar, buqh, and busi; underlies units bar (130.3 $\pm 5.0 \mathrm{ka})$, bsas $(115.3 \pm 7.5 \mathrm{ka})$, and bsof $(24.4 \pm 1.3 \mathrm{ka}) .{ }^{40} \mathrm{Ar} /{ }^{39} \mathrm{Ar}$ age, $154.8 \pm 5.5 \mathrm{ka}$ [B2, C2]

Hawaiite of Al Malsaa 3 (middle Pleistocene) —Pāhoehoe and 'a'ā hawaiite and alkalic basalt (47.6-49.0\% $\left.\mathrm{SiO}_{2} ; 1.46-1.56 \% \mathrm{~K}_{2} \mathrm{O}\right)$ lava flows, subdued relief; associated scoria cone. Contains phenocrysts of plagioclase $(1 \%, \leq 8 \mathrm{~mm})$ and olivine $(\leq 1 \%, \leq 1 \mathrm{~mm})$. Exposed over only $0.5 \mathrm{~km}^{2}$; lava flows reach at least $0.4 \mathrm{~km}$ from vent. Overlies units bm1 (230.7 $\pm 4.4 \mathrm{ka}), \mathrm{bm} 2$, and oma [D2]

Mugearite of Dabaa 1 (late Pleistocene) - 'A' 'à and pāhoehoe alkalic basalt, hawaiite, mugearite, and benmoreite $\left(47.6-55.5 \% \mathrm{SiO}_{2} ; 0.77-2.92 \% \mathrm{~K}_{2} \mathrm{O}\right)$ lava flows, very rough relief; associated partly collapsed scoria cone. Contains phenocrysts of plagioclase $(2-5 \%, \leq 10 \mathrm{~mm})$, olivine $(\leq 1 \%, \leq 4 \mathrm{~mm})$, and clinopyroxene $(1 \%, \leq 1 \mathrm{~mm})$. Exposed over $4.7 \mathrm{~km}^{2}$; lava flows reach at least $5.3 \mathrm{~km}$ from vent. Parts of unit are uplifted by domes of units td1 (17.6 $\pm 1.8 \mathrm{ka})$ and tg2 (93.8 $\pm 2.1 \mathrm{ka})$. Overlies units bd1 (717.7 $\pm 12.2 \mathrm{ka}), \mathrm{bg} 1$, bjb, and mma (154.0 $\pm 8.3 \mathrm{ka})$; underlies units bsas $(115.3 \pm 7.5 \mathrm{ka})$, td1 $(17.6 \pm 1.8 \mathrm{ka})$, and tg2 $(93.8 \pm 2.1 \mathrm{ka}) .{ }^{40} \mathrm{Ar} /{ }^{39} \mathrm{Ar}$ ages, $115.7 \pm 3.5$ ka, $118.4 \pm 4.5 \mathrm{ka}$; eruption age, $116.7 \pm 2.8 \mathrm{ka}$ (weighted mean age); paleomagnetic similarities indicate that unit correlates in time with eruption of unit bsas $(115.3 \pm 7.5 \mathrm{ka})$ [C2, D2]

Mugearite of Matan (middle Pleistocene) - 'A' $\mathrm{a}$ and pāhoehoe mugearite and hawaiite (48.2-50.9\% $\left.\mathrm{SiO}_{2} ; 1.72-2.35 \% \mathrm{~K}_{2} \mathrm{O}\right)$ lava flows, very rough relief; well-defined channels and levees; associated partly collapsed scoria cone. Contains phenocrysts of plagioclase $(1-2 \%, \leq 10 \mathrm{~mm})$, olivine $(<1 \%$, $\leq 2 \mathrm{~mm})$, and clinopyroxene $(<1 \%, \leq 1 \mathrm{~mm})$. Exposed over $18.2 \mathrm{~km}^{2}$; lava flows reach $10.3 \mathrm{~km}$

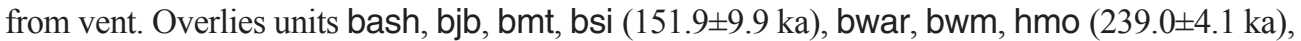
and oba (242.8 $\pm 2.4 \mathrm{ka})$; underlies units bms (59.1 $\pm 5.7 \mathrm{ka})$, md1 (116.7 $\pm 2.8 \mathrm{ka}), \operatorname{tg} 2(93.8 \pm 2.1$ $\mathrm{ka})$, tma (121.5 $\pm 1.4 \mathrm{ka})$, and tmo $(31.9 \pm 2.1 \mathrm{ka}) .{ }^{40} \mathrm{Ar} /{ }^{39} \mathrm{Ar}$ age, $154.0 \pm 8.3 \mathrm{ka}[\mathrm{C} 2, \mathrm{D} 1, \mathrm{D} 2]$

Mugearite of Mukhayar (late Pleistocene) - 'A' $\mathrm{a}$ and pāhoehoe mugearite $\left(48.8-49.4 \% \mathrm{SiO}_{2}\right.$; $1.94-1.96 \% \mathrm{~K}_{2} \mathrm{O}$ ) lava flows, very rough relief; well-defined channels, levees, and inflated surfaces; associated scoria-cone complex has three craters. Aphyric. Exposed over $59.4 \mathrm{~km}^{2}$; lava flows reach $15.6 \mathrm{~km}$ from vent. Overlies units bme, bmk (261.3 $\pm 19.1 \mathrm{ka})$, bqar, bsah

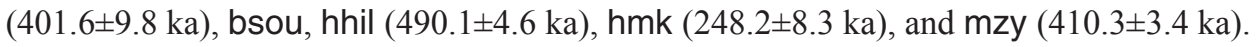
${ }^{40} \mathrm{Ar} /{ }^{39} \mathrm{Ar}$ age, $114.4 \pm 8.5 \mathrm{ka}[\mathrm{E} 2, \mathrm{~F} 2]$

Benmoreite of Gura 2 (late Pleistocene) - ' $\mathrm{A}$ ' $\mathrm{a}$ and pāhoehoe benmoreite (56.1-56.5\% $\mathrm{SiO}_{2}$; 3.17$3.18 \% \mathrm{~K}_{2} \mathrm{O}$ ) lava flows, subdued relief. Contains phenocrysts of plagioclase and K-rich feldspars (anorthoclase and sanidine) (together, $\leq 1 \%, \leq 8 \mathrm{~mm}$ ), fayalitic olivine $(<1 \%, \leq 3 \mathrm{~mm}$ ), and clinopyroxene $(1 \%, \leq 1 \mathrm{~mm})$. Vent was destroyed during eruption of unit tg2 (93.8 $\pm 2.1 \mathrm{ka})$. Exposed over only $0.2 \mathrm{~km}^{2}$; lava flows reach at least $1.4 \mathrm{~km}$ from vent. Overlies units bd1 $(717.7 \pm 12.2$ $\mathrm{ka})$ and oju (424.2 $\pm 1.8 \mathrm{ka}, 437.6 \pm 4.3 \mathrm{ka})$; underlies unit tg2 $(93.8 \pm 2.1 \mathrm{ka}) .{ }^{40} \mathrm{Ar} /{ }^{39} \mathrm{Ar}$ age, $128.2 \pm 4.2 \mathrm{ka}$. On the basis of its uncertainty, unit age could be late or middle Pleistocene [D2]

Benmoreite of Al Qara'in (middle Pleistocene) - Benmoreite $\left(56.3 \% \mathrm{SiO}_{2} ; 3.21 \% \mathrm{~K}_{2} \mathrm{O}\right)$ lava dome. Contains phenocrysts of plagioclase and K-rich feldspars (anorthoclase and sanidine) (together, $5 \%, \leq 4 \mathrm{~mm}$ ). Exposed over only $0.2 \mathrm{~km}^{2}$. Overlies unit bqar [F2]

Benmoreite of Radio Tower (middle Pleistocene) - Benmoreite and mugearite (53.6-56.5\% $\mathrm{SiO}_{2}$; $2.99-3.24 \% \mathrm{~K}_{2} \mathrm{O}$ ) lava dome and block-and-ash-flow deposit. Contains phenocrysts of plagioclase and K-rich feldspars (anorthoclase and sanidine) (together, $<1-2 \%, \leq 3 \mathrm{~mm}$ ), fayalitic olivine $(<1 \%, \leq 1 \mathrm{~mm})$, and amphibole $(2-4 \%, \leq 4 \mathrm{~mm})$. Exposed over only $0.2 \mathrm{~km}^{2}$. Overlies unit brt; underlies units bwar and har [C2]

Trachyte of Gura 3 (middle Pleistocene) - Trachyte $\left(63.0-64.3 \% \mathrm{SiO}_{2} ; 4.35-4.71 \% \mathrm{~K}_{2} \mathrm{O}\right)$ pyroclasticflow deposits. Source from $0.6-\mathrm{km}$-diameter crater. Contains phenocrysts of K-rich feldspars (anor- 
tma

$\mathrm{tz2}$

bam1 badh

bag

bahu

badb

bahu

thoclase and sanidine) (together, 3-50\%, $\leq 3 \mathrm{~mm}$ ) and clinopyroxene (aegirine and augite) (together, $\leq 1 \%, \leq 1 \mathrm{~mm}$ ) within abundant, poorly inflated juvenile clasts. Lithic clasts include previously erupted basaltic lavas. Exposed over $4.0 \mathrm{~km}^{2}$; pyroclastic-flow deposits reach at least $3.0 \mathrm{~km}$ from source. Compared to other pyroclastic-flow deposits, unit is mostly continuous, and its margins are not as ragged or do not have as many small, isolated outcrops; small, disconnected outcrops that do exist are preserved in low-lying areas within high-standing pressure ridges and tumuli from older, underlying lava flows. Juvenile clasts from unit are petrographically similar to those of unit tg2 $(93.8 \pm 2.1 \mathrm{ka})$, but they are geochemically distinct. Overlies units bda $(223.0 \pm 18.9 \mathrm{ka})$, bhy $(235.1 \pm 7.5 \mathrm{ka})$, buh, bya, murr, and og3 (558.7 $\pm 4.8 \mathrm{ka})$; underlies unit tg2 (93.8 $\pm 2.1 \mathrm{ka}) .{ }^{40} \mathrm{Ar} /{ }^{39} \mathrm{Ar}$ age, $142.4 \pm 2.2 \mathrm{ka}$ [D2]

Trachyte of Matan (late Pleistocene) — Trachyte (62.7-64.1\% $\mathrm{SiO}_{2} ; 4.78-5.04 \% \mathrm{~K}_{2} \mathrm{O}$ ) lava dome and pyroclastic-flow deposits. Contains phenocrysts of K-rich feldspars (anorthoclase and sanidine) (together, $3-10 \%, \leq 3 \mathrm{~mm}$ ) and clinopyroxene (aegirine and augite) (together, $\leq 1 \%, \leq 1 \mathrm{~mm}$ ) within abundant, poorly inflated juvenile clasts. Pyroclastic deposits erupted from partly exposed $0.4-\mathrm{km}-$ diameter crater, followed by emplacement of $1.6-\mathrm{km}$-diameter lava dome that has smaller, $0.2-\mathrm{km}-$ diameter crater near its summit. Dome extrusion resulted in uplift of lava flows of units bmt, hmo $(239.0 \pm 4.1 \mathrm{ka})$, and $\mathrm{mma}(154.0 \pm 8.3 \mathrm{ka})$. Exposed over $2.5 \mathrm{~km}^{2}$; pyroclastic deposits reach at least $1.4 \mathrm{~km}$ from source. Margins have ragged appearance; a few small, isolated outcrops of pyroclastic deposits are preserved in low-lying areas between taller pressure ridges and tumuli of unit mma $(154.0 \pm 8.3 \mathrm{ka})$ lava flows. Juvenile clasts of unit are visually similar to those of overlying unit tmo $(31.9 \pm 2.1 \mathrm{ka})$ and are most easily distinguished using geochemical characteristics. Overlies units hmo (239.0 $\pm 4.1 \mathrm{ka})$ and mma (154.0 $\pm 8.3 \mathrm{ka})$; underlies unit tmo $(31.9 \pm 2.1 \mathrm{ka}) .{ }^{40} \mathrm{Ar} /{ }^{39} \mathrm{Ar}$ ages, $120.6 \pm 2.1 \mathrm{ka}, 122.3 \pm 1.9 \mathrm{ka}$; eruption age, $121.5 \pm 1.4 \mathrm{ka}$ (weighted mean age) [C2, D2]

Trachyte of Um Znabah 2 (late Pleistocene) - Trachyte (60.5-62.6\% $\mathrm{SiO}_{2} ; 4.51-5.16 \% \mathrm{~K}_{2} \mathrm{O}$ ) lava dome ( $0.9 \mathrm{~km}$ diameter) and minor pyroclastic-flow deposits. Contains phenocrysts of K-rich feldspar (anorthoclase and sanidine) (together, 1-5\%, $\leq 1 \mathrm{~mm}$ ). Lava-dome extrusion has resulted

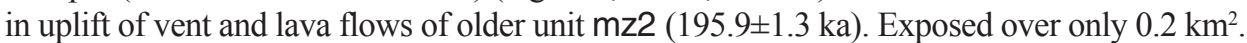
Underlies units tef $(88.0 \pm 1.8 \mathrm{ka})$ and $\operatorname{tg} 4(84.3 \pm 1.6 \mathrm{ka})$; unit appears (erroneously) to underlie older unit $\mathrm{mz2}(195.9 \pm 1.3 \mathrm{ka})$ because it has uplifted older unit's vent and lava flows. ${ }^{40} \mathrm{Ar} /{ }^{39} \mathrm{Ar}$ ages, $116.9 \pm 2.9 \mathrm{ka}, 124.5 \pm 2.4 \mathrm{ka}, 128.8 \pm 12.6 \mathrm{ka}$; eruption age, $121.6 \pm 1.8 \mathrm{ka}$ (weighted mean age) [E2]

\section{Eruptive Stage 6 (180 to $260 \mathrm{ka})$}

Basalt of Al Adhbah (middle Pleistocene) - Pāhoehoe and 'a'ā basaltic lava flows, subdued relief. Exposed over $7.4 \mathrm{~km}^{2}$; lava flows reach at least $6.1 \mathrm{~km}$ from vent. Overlies units bduw, bjab $(324.7 \pm 29.3 \mathrm{ka})$, and bsy $(236.2 \pm 29.2 \mathrm{ka})$; underlies units bqg (215.2 $\pm 6.9 \mathrm{ka})$ and bsf $(217.5 \pm 6.7 \mathrm{ka})[\mathrm{D} 1]$

Basalt of Adh Dhiyabah (middle Pleistocene) - Pāhoehoe alkalic basalt $\left(47.3 \% \mathrm{SiO}_{2} ; 0.68 \% \mathrm{~K}_{2} \mathrm{O}\right)$ lava flows, moderate relief; associated scoria cone. Contains olivine phenocrysts $(1 \%, \leq 1 \mathrm{~mm})$. Exposed over $9.4 \mathrm{~km}^{2}$; lava flows reach at least $4.0 \mathrm{~km}$ from vent. Overlies units bmd, bssu $(313.9 \pm 11.3 \mathrm{ka})$, and buru; underlies unit buak. ${ }^{40} \mathrm{Ar} /{ }^{39} \mathrm{Ar}$ age, $208.9 \pm 16.9 \mathrm{ka}$ [F2]

Basalt of Abu Ghuwayshiyah (middle Pleistocene) —Pāhoehoe and 'a'ā alkalic basalt (47.5-47.6\% $\mathrm{SiO}_{2} ; 1.00-1.13 \% \mathrm{~K}_{2} \mathrm{O}$ ) lava flows, very rough relief; well-defined pressure-ridges, levees, and channels; associated 2.5-km-long, elongate scoria-cone complex has six craters. Contains phenocrysts of plagioclase $(1 \%, \leq 10 \mathrm{~mm})$ and olivine $(1-4 \%, \leq 10 \mathrm{~mm})$. Exposed over $25.8 \mathrm{~km}^{2}$; lava flows reach $10.5 \mathrm{~km}$ from vent. Ground crack, which breaks lava-flow surface of unit, is interpreted to have formed during eruption of unit bsof (24.4 $\pm 1.3 \mathrm{ka})$. Overlies units bhb $(246.4 \pm 25.0$ ka) and bli; underlies units bcef $(24.4 \pm 1.3 \mathrm{ka})$, bdy $(139.2 \pm 11.3 \mathrm{ka})$, bnof $(24.4 \pm 1.3 \mathrm{ka})$, and bsof $(24.4 \pm 1.3 \mathrm{ka})$; younger unit bna $(162.9 \pm 11.1 \mathrm{ka})$ flowed around its margin. ${ }^{40} \mathrm{Ar} /{ }^{39} \mathrm{Ar}$ ages, $216.8 \pm 13.5 \mathrm{ka}, 222.5 \pm 10.6 \mathrm{ka}$; eruption age, $220.3 \pm 8.3 \mathrm{ka}$ (weighted mean age); paleomagnetic similarities indicate that unit correlates in time with eruption of unit bqg $(215.2 \pm 6.9 \mathrm{ka})$ [B2, C2]

Basalt of Al Hulays (middle Pleistocene)_Pāhoehoe and 'a'ā basaltic lava flows, moderate relief; associated 2-km-long, elongate scoria-cone complex. Exposed over $5.7 \mathrm{~km}^{2}$; lava flows reach at least $4.9 \mathrm{~km}$ from vent. Overlies units bawa, bsah (401.6 $\pm 9.8 \mathrm{ka})$, and bsou; underlies units bqar, buru, and twa $(39.2 \pm 1.6 \mathrm{ka})$ [F2]

Basalt of Amlit 1 (middle Pleistocene) - Pāhoehoe and 'a'ā alkalic basalt (46.4-47.9\% $\mathrm{SiO}_{2}$; $0.52-1.21 \% \mathrm{~K}_{2} \mathrm{O}$ ) lava flows, rough relief; moderately eroded pressure ridges; associated 0.9-kmlong, elongate scoria cone has three craters. Contains phenocrysts of plagioclase $(1 \%, \leq 2 \mathrm{~mm})$ and olivine $(<1-5 \%, \leq 4 \mathrm{~mm})$. Exposed over $3.6 \mathrm{~km}^{2}$; lava flows reach at least $2.4 \mathrm{~km}$ from vent. Underlies units bam2, bam3, bam4, and bsi (151.9 $\pm 9.9 \mathrm{ka}) .{ }^{40} \mathrm{Ar} /{ }^{39} \mathrm{Ar}$ age, $252.2 \pm 6.8 \mathrm{ka}$ [C2] 
Basalt of Amlit 2 (middle Pleistocene) - Pāhoehoe and 'a'ā alkalic basalt (47.5-48.0\% $\mathrm{SiO}_{2}$; $0.97-1.08 \% \mathrm{~K}_{2} \mathrm{O}$ ) lava flows, moderately rough relief; associated $0.3-\mathrm{km}$-long, elongate scoria cone has two craters. Contains phenocrysts of plagioclase $(1 \%, \leq 60 \mathrm{~mm})$ and olivine $(1 \%, \leq 2$ $\mathrm{mm})$. Exposed over $1.8 \mathrm{~km}^{2}$; lava flows reach at least $3.0 \mathrm{~km}$ from vent. Overlies unit bam1 (252.2 $\pm 6.8 \mathrm{ka})$; underlies units bam3 and mh11 [C2]

bam3

bam4

bawa

bbd

$\mathrm{bbr}$

bda

bdr

besa

bh81

bhb

bhy

Basalt of Amlit 3 (middle Pleistocene) - Pāhoehoe basaltic lava flows, very subdued relief; associated scoria cone. Exposed over only $0.3 \mathrm{~km}^{2}$; lava flows reach at least $1.0 \mathrm{~km}$ from vent. Overlies units bam1 (252.2 $\pm 6.8 \mathrm{ka})$ and bam2; underlies unit bam4 [C2]

Basalt of Amlit 4 (middle Pleistocene) - 'A'ā basaltic lava flows, rough, hummocky relief; associated scoria cone. Exposed over $3.2 \mathrm{~km}^{2}$; lava flows reach at least $0.8 \mathrm{~km}$ from vent. Ground crack, which breaks lava-flow surface of unit, is interpreted to have formed during eruption of unit bsof ( $24.4 \pm 1.3$ ka). Overlies units bam1 (252.2 $\pm 6.8 \mathrm{ka})$ and bam3; underlies units bsi (151.9 $\pm 9.9 \mathrm{ka})$ and $\mathrm{mh} 11$ [C2]

Basalt of Al Wabarah (middle Pleistocene) - Pāhoehoe basaltic lava flows, subdued relief; associated $0.7-\mathrm{km}$-long, elongate scoria cone has three craters. Exposed over $1.4 \mathrm{~km}^{2}$; lava flows reach at least $1.1 \mathrm{~km}$ from vent. Overlies unit basu (453.4 $\pm 12.8 \mathrm{ka})$; underlies units bahu, bqar, and twa (39.2 $\pm 1.6 \mathrm{ka})[\mathrm{F} 2]$

Basalt of Banthane Dam (middle Pleistocene) —Pāhoehoe and 'a'ā alkalic basalt (45.6-45.9\% $\left.\mathrm{SiO}_{2} ; 0.71-0.93 \% \mathrm{~K}_{2} \mathrm{O}\right)$ lava flows, subdued relief. Contains phenocrysts of plagioclase (1-2\%, $\leq 10 \mathrm{~mm}$ ) and olivine $(<1-2 \%, \leq 4 \mathrm{~mm})$. Exposed over $6.3 \mathrm{~km}^{2}$; lava flows reach at least 4.5 $\mathrm{km}$ from vent. Overlies units bai $(546.2 \pm 9.6 \mathrm{ka})$, bqr, and brh $(411.5 \pm 5.9 \mathrm{ka})$; underlies units bnu $(131.2 \pm 8.3 \mathrm{ka})$, bru, and bsh $(191.5 \pm 4.2 \mathrm{ka}) .{ }^{40} \mathrm{Ar} /{ }^{39} \mathrm{Ar}$ age, $223.4 \pm 8.6 \mathrm{ka}$; paleomagnetic similarities indicate that unit correlates in time with eruption of unit blsl $(228.6 \pm 12.0 \mathrm{ka})$ [B1]

Basalt of Al Buraysha (middle Pleistocene) - Pāhoehoe basaltic lava flows, subdued relief. Exposed over $4.0 \mathrm{~km}^{2}$; lava flows reach at least $3.6 \mathrm{~km}$ from vent. Underlies units bhb $(246.4 \pm 25.0 \mathrm{ka})$ and bna $(162.9 \pm 11.1 \mathrm{ka})[\mathrm{A} 2]$

Basalt of Ad Darah (middle Pleistocene) — Pāhoehoe and 'a'ā tholeiitic and alkalic basalt (47.3$48.1 \% \mathrm{SiO}_{2} ; 0.28-0.63 \% \mathrm{~K}_{2} \mathrm{O}$ ) lava flows, subdued relief; associated scoria cone. Contains phenocrysts of plagioclase $(\leq 1 \%, \leq 10 \mathrm{~mm})$ and olivine $(<1-5 \%, \leq 8 \mathrm{~mm})$. Exposed over 7.0 $\mathrm{km}^{2}$; lava flows reach $8.5 \mathrm{~km}$ from vent. Overlies units bss (461.9 $\left.\pm 4.9 \mathrm{ka}\right)$, bwhu, murr, and

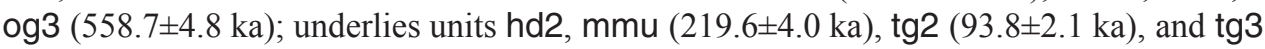
$(142.4 \pm 2.2 \mathrm{ka}) .{ }^{40} \mathrm{Ar} /{ }^{39} \mathrm{Ar}$ age, $223.0 \pm 18.9 \mathrm{ka}$ [D2]

Basalt of Dab Al Harus (middle Pleistocene) - Pāhoehoe and 'a'ā alkalic basalt (46.6\% $\mathrm{SiO}_{2}$; $0.72 \% \mathrm{~K}_{2} \mathrm{O}$ ) lava flows, moderately rough relief; associated partly collapsed scoria cone. Contains olivine phenocrysts $(1 \%, \leq 2 \mathrm{~mm})$. Exposed over $5.4 \mathrm{~km}^{2}$; lava flows reach at least 5.4 $\mathrm{km}$ from vent. Overlies unit bh86 (285.4 $\pm 20.1 \mathrm{ka})$; underlies units bjr (207.3 $\pm 8.4 \mathrm{ka})$ and bsf $(217.5 \pm 6.7 \mathrm{ka}) .{ }^{40} \mathrm{Ar} /{ }^{39} \mathrm{Ar}$ age, $232.7 \pm 15.9 \mathrm{ka}[\mathrm{D} 1, \mathrm{E} 1]$

Basalt east of Al Shathaa (middle Pleistocene) —Pāhoehoe and 'a'ā basaltic lava flows, moderately subdued relief; associated 0.6-km-long, elongate vent has two craters and spatter ramparts; offset $10 \mathrm{~m}$ by normal fault. Exposed over $6.3 \mathrm{~km}^{2}$; lava flows reach at least $7.8 \mathrm{~km}$ from

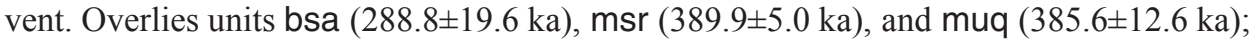
underlies unit $\mathrm{mmu}(219.6 \pm 4.0 \mathrm{ka})[\mathrm{D} 2]$

Basalt of Hill 810 (middle Pleistocene) - Pāhoehoe and 'a'ā alkalic basalt (47.0\% $\mathrm{SiO}_{2} ; 0.95 \%$ $\mathrm{K}_{2} \mathrm{O}$ ) lava flows, moderate to subdued relief; three associated scoria cones. Contains phenocrysts of plagioclase $(4 \%, \leq 9 \mathrm{~mm})$ and olivine $(2 \%, \leq 4 \mathrm{~mm})$. Exposed over $3.6 \mathrm{~km}^{2}$; lava flows reach at least $1.5 \mathrm{~km}$ from vent. Underlies unit bsf (217.5 $\pm 6.7 \mathrm{ka})$ [D1]

Basalt of Hamra Al Bidun (middle Pleistocene) —Pāhoehoe and 'a'ā alkalic basalt (46.3-46.5\% $\mathrm{SiO}_{2} ; 0.51-0.54 \% \mathrm{~K}_{2} \mathrm{O}$ ) lava flows, rough relief; well-defined pressure ridges, channels, and levees. Contains phenocrysts of plagioclase $(1-2 \%, \leq 7 \mathrm{~mm})$ and olivine $(7 \%, \leq 8 \mathrm{~mm})$. Exposed over $14.6 \mathrm{~km}^{2}$; lava flows reach at least $7.5 \mathrm{~km}$ from vent. Overlies unit bbr; underlies units bag (220.3 $\pm 8.3 \mathrm{ka})$, bcef $(24.4 \pm 1.3 \mathrm{ka})$, bnof $(24.4 \pm 1.3 \mathrm{ka})$, and bsof ( $24.4 \pm 1.3 \mathrm{ka})$; younger unit hma $(220.5 \pm 10.9 \mathrm{ka})$ flowed around margin of this unit. ${ }^{40} \mathrm{Ar} /{ }^{39} \mathrm{Ar}$ age, $246.4 \pm 25.0 \mathrm{ka}$ [A2, B2]

Basalt of Sha'ib Hayaya (middle Pleistocene) - Pāhoehoe and 'a'ā alkalic basalt, hawaiite, and mugearite $\left(48.2-49.8 \% \mathrm{SiO}_{2} ; 1.03-1.89 \% \mathrm{~K}_{2} \mathrm{O}\right)$ lava flows, rough to moderately rough relief; associated partly collapsed scoria cone. Contains phenocrysts of plagioclase $(<1 \%, \leq 15 \mathrm{~mm})$ and olivine $(3 \%, \leq 2 \mathrm{~mm})$. Exposed over $28.8 \mathrm{~km}^{2}$; lava flows reach at least $9.9 \mathrm{~km}$ from vent. Overlies units buh, bya, oju (424.2 $\pm 1.8 \mathrm{ka}, 437.6 \pm 4.3 \mathrm{ka})$, and osb (535.8 $\pm 11.8 \mathrm{ka})$; underlies units bsas (115.3 \pm 7.5 $\mathrm{ka}), \mathrm{mmu}(219.6 \pm 4.0 \mathrm{ka})$, and tg3 $(142.4 \pm 2.2 \mathrm{ka}) .{ }^{40} \mathrm{Ar}{ }^{\beta 9} \mathrm{Ar}$ age, $235.1 \pm 7.5 \mathrm{ka}$; paleomagnetic similarities indicate that unit correlates in time with eruption of unit bsy (236.2 $\pm 29.2 \mathrm{ka})$ [D2] 
Basalt of Umm Jurmat (middle Pleistocene) —Pāhoehoe and ' $a$ 'ā alkalic basalt (46.8-46.9\% $\mathrm{SiO}_{2}$; $0.80-0.94 \% \mathrm{~K}_{2} \mathrm{O}$ ) lava flows, moderate relief; associated 0.6-km-long, elongate scoria cone has three craters. Contains phenocrysts of plagioclase $(1 \%, \leq 10 \mathrm{~mm})$ and olivine $(1 \%, \leq 1 \mathrm{~mm})$. Exposed over $18.4 \mathrm{~km}^{2}$; two branching lava-flow lobes, northern and southern, reach at least $9.0 \mathrm{~km}$ and at least 8.4 $\mathrm{km}$, respectively, from vent. Overlies units bada, bdr (232.7 $\pm 15.9 \mathrm{ka})$, bedh, bfa, bh86 (285.4 \pm 20.1 ka), bsf (217.5 $\pm 6.7 \mathrm{ka})$, bsm, bwh8, and bwhu. ${ }^{40} \mathrm{Ar}{ }^{\beta 9} \mathrm{Ar}$ age, 207.3 $\pm 8.4 \mathrm{ka}$ [D1, E1]

bjs

bli

blqa

blqh

blsl

bm1

bmd

bme

bml

bmt

bqar

Basalt of Al Jassah (middle Pleistocene) - Pāhoehoe and 'a'ā alkalic basalt (46.5\% $\mathrm{SiO}_{2} ; 0.73 \%$ $\mathrm{K}_{2} \mathrm{O}$ ) lava flows, very subdued relief. Aphyric. Exposed over $5.5 \mathrm{~km}^{2}$; lava flows reach at least $5.5 \mathrm{~km}$ from vent. Overlies units bhu $(285.1 \pm 6.6 \mathrm{ka})$ and bsh $(191.5 \pm 4.2 \mathrm{ka})$; underlies units bsk and han3 $(51.0 \pm 9.0 \mathrm{ka})$. Paleomagnetic similarities indicate that unit correlates in time with eruption of unit bru [B1]

Basalt of Al Billa'ah (middle Pleistocene) - 'A'ā and pāhoehoe basaltic lava flows, moderately rough relief; associated scoria-cone complex has two craters and spatter ramparts. Exposed over $3.4 \mathrm{~km}^{2}$; lava flows reach at least $2.0 \mathrm{~km}$ from vent. Underlies units bag (220.3 $\left.\pm 8.3 \mathrm{ka}\right)$, bh10 (137.3 $\pm 11.3 \mathrm{ka})$, bsof $(24.4 \pm 1.3 \mathrm{ka})$, and mh11 [C2]

Basalt of Lower Qa Al Aqul (middle Pleistocene) - 'A'à and pāhoehoe alkalic basalt (46.4-46.6\% $\left.\mathrm{SiO}_{2} ; 0.69-0.71 \% \mathrm{~K}_{2} \mathrm{O}\right)$ lava flows, subdued relief. Contains phenocrysts of plagioclase $(<1 \%$, $\leq 8 \mathrm{~mm})$ and olivine $(1 \%, \leq 1 \mathrm{~mm})$. Exposed over $4.4 \mathrm{~km}^{2}$; lava flows reach at least $4.0 \mathrm{~km}$ from vent. Underlies units bka (144.6 $\pm 19.6 \mathrm{ka})$ and bna $(162.9 \pm 11.1 \mathrm{ka})$; flowed around older units bsl and buqa $(1,069.6 \pm 19.3 \mathrm{ka}) .{ }^{40} \mathrm{Ar} /{ }^{39} \mathrm{Ar}$ age, $196.9 \pm 10.3 \mathrm{ka}$ [A1, A2]

Basalt of Lower Qa Hadawda (middle Pleistocene) - Pāhoehoe and minor ' $a$ 'ā tholeiitic basalt (47.4-47.5\% $\left.\mathrm{SiO}_{2} ; 0.36-0.37 \% \mathrm{~K}_{2} \mathrm{O}\right)$ lava flows, subdued relief. Contains phenocrysts of plagioclase $(<1 \%, \leq 15 \mathrm{~mm})$ and olivine $(1-5 \%, \leq 8 \mathrm{~mm})$. Exposed over $7.1 \mathrm{~km}^{2}$; lava flows reach at least $3.2 \mathrm{~km}$ from vent. Underlies units buqh and hlh (154.8 $\pm 5.5 \mathrm{ka})$ [B2, C2]

Basalt of Lower Sha'ib Lihyan (middle Pleistocene) - 'A'ā and pāhoehoe alkalic basalt (46.2-47.5\% $\mathrm{SiO}_{2} ; 0.55-1.08 \% \mathrm{~K}_{2} \mathrm{O}$ ) lava flows, moderately rough relief. Contains phenocrysts of plagioclase $(1-3 \%, \leq 10 \mathrm{~mm})$ and olivine $(<1-2 \%, \leq 8 \mathrm{~mm})$. Exposed over $10.6 \mathrm{~km}^{2}$; lava flows reach at least $6.9 \mathrm{~km}$ from vent. Underlies unit hlh $(154.8 \pm 5.5 \mathrm{ka}) .{ }^{40} \mathrm{Ar} /{ }^{39} \mathrm{Ar}$ age, $228.6 \pm 12.0 \mathrm{ka}$; paleomagnetic similarities indicate that unit correlates in time with eruption of unit bbd (223.4 $\pm 8.6 \mathrm{ka})$ [C2]

Basalt of Al Malsaa 1 (middle Pleistocene) - Pāhoehoe and minor 'a'ā alkalic and tholeiitic basalt $\left(46.8-48.7 \% \mathrm{SiO}_{2} ; 0.38-1.41 \% \mathrm{~K}_{2} \mathrm{O}\right)$ lava flows, subdued relief; associated low-lying shield volcano has spatter ramparts. Contains phenocrysts of plagioclase $(1 \%, \leq 4 \mathrm{~mm})$ and olivine $(1-2 \%$, $\leq 4 \mathrm{~mm}$ ). Exposed over $4.0 \mathrm{~km}^{2}$; lava flows reach at least $5.2 \mathrm{~km}$ from vent. Overlies units oba $(242.8 \pm 2.4 \mathrm{ka})$ and oma; underlies units bm2, hm3, and murr. ${ }^{40} \mathrm{Ar} /{ }^{39} \mathrm{Ar}$ age, $230.7 \pm 4.4 \mathrm{ka}$ [D2]

Basalt of Al Madba'ah (middle Pleistocene) - 'A' $' \bar{a}$ and pāhoehoe tholeiitic basalt (46.2\% $\mathrm{SiO}_{2}$; $0.51 \% \mathrm{~K}_{2} \mathrm{O}$ ) lava flows, rough relief; associated $1.1-\mathrm{km}$-long, elongate, partly collapsed scoriacone complex. Contains olivine phenocrysts $(7 \%, \leq 10 \mathrm{~mm})$. Exposed over $8.8 \mathrm{~km}^{2}$; lava flows reach at least $4.1 \mathrm{~km}$ from vent. Overlies units bhag, bri (438.9 $21.0 \mathrm{ka})$, and buaa; underlies units badh $(208.9 \pm 16.9 \mathrm{ka})$ and buak [F1, F2]

Basalt of Al Mesba'ah (middle Pleistocene) - 'A' $' \bar{a}$ and pāhoehoe basaltic lava flows, moderate relief. Exposed over $19.1 \mathrm{~km}^{2}$; lava flows reach at least $9.1 \mathrm{~km}$ from vent. Overlies units bmk $(261.3 \pm 19.1 \mathrm{ka})$ and bqa; underlies units bns and $\mathrm{mmk}(114.4 \pm 8.5 \mathrm{ka})$. Stratigraphic relations farther south are undefined, as this is southernmost extent of map area [F2]

Basalt of Al Mulaysa (middle Pleistocene) - 'A' $' \bar{a}$ and pāhoehoe alkalic basalt (47.6-47.9\% $\mathrm{SiO}_{2}$; $1.08-1.13 \% \mathrm{~K}_{2} \mathrm{O}$ ) lava flows, moderately subdued relief; two associated $0.8-\mathrm{km}-\mathrm{long}$, elongate scoria cones. Contains olivine phenocrysts $(<1-4 \%, \leq 4 \mathrm{~mm})$. Exposed over $22.8 \mathrm{~km}^{2}$; lava flows reach $7.9 \mathrm{~km}$ from vent. Overlies units bgh, bhag, bja (698.1 $\pm 16.0 \mathrm{ka})$, bmh, bqaq, bsam, bsaw, buph $(510.8 \pm 29.4 \mathrm{ka})$, and busb $(302.3 \pm 14.8 \mathrm{ka})$; underlies unit bso. ${ }^{40} \mathrm{Ar} /{ }^{39} \mathrm{Ar}$ ages, $218.1 \pm 9.1 \mathrm{ka}, 225.0 \pm 7.6 \mathrm{ka}$; eruption age, $222.2 \pm 5.8 \mathrm{ka}$ (weighted mean age) [E1, F1]

Basalt of Matan (middle Pleistocene) - 'A' ${ }^{\prime} \bar{a}$ and pāhoehoe alkalic and tholeiitic basalt (46.6$47.7 \% \mathrm{SiO}_{2} ; 0.41-0.77 \% \mathrm{~K}_{2} \mathrm{O}$ ) lava flows, moderate to subdued relief; associated partly exposed scoria cone. Contains phenocrysts of plagioclase $(<1 \%, \leq 20 \mathrm{~mm})$ and olivine $(10 \%, \leq 7$ $\mathrm{mm})$. Parts of lava flows are uplifted by lava dome of unit tma (121.5 $\pm 1.4 \mathrm{ka})$. Exposed over only $0.3 \mathrm{~km}^{2}$; lava flows reach at least $2.4 \mathrm{~km}$ from vent. Underlies units hmo (239.0 $\left.\pm 4.1 \mathrm{ka}\right)$, $\mathrm{mma}(154.0 \pm 8.3 \mathrm{ka})$, and tmo $(31.9 \pm 2.1 \mathrm{ka})[\mathrm{C} 2, \mathrm{D} 2]$

Basalt of Al Qara'in (middle Pleistocene) — 'A'āa and pāhoehoe alkalic basalt (49.1\% $\left.\mathrm{SiO}_{2} ; 1.26 \% \mathrm{~K}_{2} \mathrm{O}\right)$ lava flows, moderately rough relief; associated $2.0-\mathrm{km}$-long, elongate scoria-cone complex has four craters. Contains phenocrysts of plagioclase $(5 \%, \leq 15 \mathrm{~mm})$ and olivine $(2 \%, \leq 4 \mathrm{~mm})$. Exposed over 
$13.0 \mathrm{~km}^{2}$; lava flows reach at least $3.4 \mathrm{~km}$ from vent. Overlies units bahu and bawa; underlies units

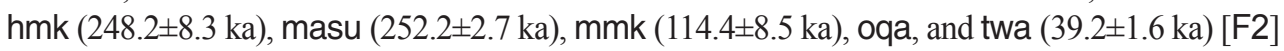

Basalt of Qa Al Ghusun (middle Pleistocene) - ' $\mathrm{A}$ 'ā and pāhoehoe alkalic basalt and hawaiite $\left(46.5-47.3 \% \mathrm{SiO}_{2} ; 0.75-1.19 \% \mathrm{~K}_{2} \mathrm{O}\right)$ lava flows, very rough relief; well-defined pressure ridges, channels, and levees. Contains phenocrysts of plagioclase $(1-10 \%, \leq 50 \mathrm{~mm})$ and olivine $(1-8 \%, \leq 8 \mathrm{~mm})$. Exposed over $39.9 \mathrm{~km}^{2}$; lava flows reach at least $21.7 \mathrm{~km}$ from vent. Overlies units badb, bh83 (505.1 $\pm 10.3 \mathrm{ka})$, bjab (324.7 $\pm 29.3 \mathrm{ka})$, bsy $(236.2 \pm 29.2 \mathrm{ka})$, bte, and bzi; underlies units bms $(59.1 \pm 5.7 \mathrm{ka})$ and han3 $(51.0 \pm 9.0 \mathrm{ka}) .{ }^{40} \mathrm{Ar} /{ }^{39} \mathrm{Ar}$ ages, $214.9 \pm 7.2 \mathrm{ka}$, $218.7 \pm 23.7 \mathrm{ka}$; eruption age, $215.2 \pm 6.9 \mathrm{ka}$ (weighted mean age); paleomagnetic similarities indicate that unit correlates in time with eruption of unit bag $(220.3 \pm 8.3 \mathrm{ka})$ [C1, D1]

bru

bsf

bsh

bso

bsy

buaa

buak

bups

buqh

Basalt of Ar Rummanah (middle Pleistocene) - ' $\mathrm{A}$ ' $\bar{a}$ and pāhoehoe alkalic basalt (46.0-46.9\% $\left.\mathrm{SiO}_{2} ; 0.82-1.02 \% \mathrm{~K}_{2} \mathrm{O}\right)$ lava flows, subdued relief. Contains phenocrysts of plagioclase (1\%, $\leq 10 \mathrm{~mm}$ ) and olivine $(\leq 1 \%, \leq 4 \mathrm{~mm})$. Exposed over $14.2 \mathrm{~km}^{2}$; lava flows reach at least $5.7 \mathrm{~km}$ from vent. Overlies units bbd (223.4 $\pm 8.6 \mathrm{ka})$ and bqr; underlies units bmat (136.7 $\pm 7.6 \mathrm{ka})$, bmz, bnu (131.2 $\pm 8.3 \mathrm{ka})$, bra, and han1 (139.0 $\pm 5.4 \mathrm{ka})$. Paleomagnetic similarities indicate that unit correlates in time with eruption of unit bjs [A1, B1]

Basalt of Umm Sufar (middle Pleistocene) - 'A'ā and pāhoehoe alkalic basalt (46.4-47.0\% $\mathrm{SiO}_{2}$; $0.82-1.02 \% \mathrm{~K}_{2} \mathrm{O}$ ) lava flows, rough relief; well-defined pressure ridges, channels, and levees; associated $0.9-\mathrm{km}$-long, elongate scoria-cone complex. Contains phenocrysts of plagioclase $(1 \%, \leq 30 \mathrm{~mm})$ and olivine $(2-3 \%, \leq 5 \mathrm{~mm})$. Exposed over $56.2 \mathrm{~km}^{2}$; lava flows reach $20.9 \mathrm{~km}$ from vent. Overlies units badb, bdr (232.7 $\pm 15.9 \mathrm{ka})$, bduw, bh81, bh86 $(285.4 \pm 20.1 \mathrm{ka})$,

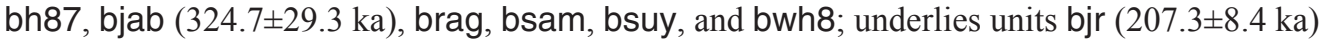
and bms $(59.1 \pm 5.7 \mathrm{ka}) .{ }^{40} \mathrm{Ar}{ }^{139} \mathrm{Ar}$ age, $217.5 \pm 6.7 \mathrm{ka}[\mathrm{D} 1, \mathrm{E} 1]$

Basalt of Shuran (middle Pleistocene) - 'A' $' \bar{a}$ and pāhoehoe alkalic basalt (46.4-47.0\% $\mathrm{SiO}_{2} ; 0.74$ $0.85 \% \mathrm{~K}_{2} \mathrm{O}$ ) lava flows, subdued relief; associated partly collapsed scoria cone. Contains phenocrysts of plagioclase $(1-2 \%, \leq 30 \mathrm{~mm})$ and olivine $(\leq 1 \%, \leq 8 \mathrm{~mm})$. Conservative reconstruction indicates that unit is present over at least $30.8 \mathrm{~km}^{2}$; lava flows reach $14.7 \mathrm{~km}$ from vent. Overlies units bai (546.2 $\pm 9.6 \mathrm{ka})$, bbd (223.4 $\pm 8.6 \mathrm{ka})$, bhu (285.1 $\pm 6.6 \mathrm{ka})$, bqu, and brh (411.5 $\pm 5.9 \mathrm{ka})$; underlies units bjs, bnu $(131.2 \pm 8.3 \mathrm{ka})$, and han3 $(51.0 \pm 9.0 \mathrm{ka}) .{ }^{40} \mathrm{Ar}{ }^{39} \mathrm{Ar}$ ages, $184.9 \pm 7.1 \mathrm{ka}, 186.6 \pm 7.0 \mathrm{ka}$, $206.5 \pm 8.1 \mathrm{ka}$; eruption age, $191.5 \pm 4.2 \mathrm{ka}$ (weighted mean age); paleomagnetic similarities indicate that part of unit correlates in time with eruption of part of unit $\mathrm{mz2}(195.9 \pm 1.3 \mathrm{ka})$; excursional remanent-magnetic directions indicate that unit erupted during Iceland Basin excursion [A1, B1, C1]

Basalt of South (middle Pleistocene) - 'A' $\mathrm{a}$ and pāhoehoe alkalic basalt (46.4-46.7\% $\mathrm{SiO}_{2}$; $0.85-0.89 \% \mathrm{~K}_{2} \mathrm{O}$ ) lava flows, moderate relief; two associated scoria-cone complexes. Contains phenocrysts of plagioclase $(2-3 \%, \leq 20 \mathrm{~mm})$ and olivine $(1 \%, \leq 10 \mathrm{~mm})$. Exposed over $11.3 \mathrm{~km}^{2}$; lava flows reach $5.4 \mathrm{~km}$ from vent. Overlies units bedh, bh86 (285.4 $\pm 20.1 \mathrm{ka})$, bja (698.1 16.0 ka), bml (222.2 $\pm 5.8 \mathrm{ka})$, bmy (660.4 $\pm 13.4 \mathrm{ka})$, bsam, and buph (510.8 $\pm 29.4 \mathrm{ka})$ [E1]

Basalt of Abu Siyilah (middle Pleistocene) - 'A'ā and pāhoehoe alkalic basalt (46.1-46.5\% $\mathrm{SiO}_{2}$; $0.75 \% \mathrm{~K}_{2} \mathrm{O}$ ) lava flows, moderate relief; two associated scoria cones. Contains olivine phenocrysts $(3-4 \%, \leq 1 \mathrm{~mm})$. Exposed over $32.0 \mathrm{~km}^{2}$; lava flows reach $20.0 \mathrm{~km}$ from vent. Overlies units bte and bzi; underlies units badb, bms (59.1 $\pm 5.7 \mathrm{ka})$, bqg $(215.2 \pm 6.9 \mathrm{ka})$, and han3 $(51.0 \pm 9.0 \mathrm{ka}) .{ }^{40} \mathrm{Ar} /{ }^{39} \mathrm{Ar}$ age, $236.2 \pm 29.2 \mathrm{ka}$; paleomagnetic similarities indicate that unit correlates in time with eruption of unit bhy $(235.1 \pm 7.5 \mathrm{ka})$ [C1, D1]

Basalt of Umm Al Awshaz (middle Pleistocene) - 'A'āa and pāhoehoe basaltic lava flows, moderately rough relief; associated scoria cone. Exposed over only $0.8 \mathrm{~km}^{2}$; lava flows reach at least $1.0 \mathrm{~km}$ from vent. Underlies units bmd and buak [F1]

Basalt of Umm Arakah (middle Pleistocene) - 'A'ā and pāhoehoe tholeiitic basalt (47.3\% $\mathrm{SiO}_{2}$; $0.33 \% \mathrm{~K}_{2} \mathrm{O}$ ) lava flows, moderately rough relief; pressure ridges, channels, and levees; associated $0.6-\mathrm{km}-\mathrm{long}$, elongate scoria cone has three craters. Contains phenocrysts of plagioclase $(<1 \%$, $\leq 7 \mathrm{~mm})$ and olivine $(3 \%, \leq 2 \mathrm{~mm})$. Exposed over $18.6 \mathrm{~km}^{2}$; lava flows reach at least $12.6 \mathrm{~km}$ from vent. Overlies units badh (208.9 $\pm 16.9 \mathrm{ka})$, bmd, bmuf, bri (438.9 $\pm 21.0 \mathrm{ka})$, and buaa [F1, F2]

Basalt of Upper Sahab (middle Pleistocene) -Pāhoehoe basaltic lava flows, subdued relief; associated 0.5 -km-long, elongate scoria cone has two craters. Exposed over only $0.5 \mathrm{~km}^{2}$; lava flows reach at least $0.8 \mathrm{~km}$ from vent. Underlies units bnof $(24.4 \pm 1.3 \mathrm{ka})$ and $\mathrm{hma}(220.5 \pm 10.9 \mathrm{ka})$ [B2]

Basalt of Upper Qa Hadawda (middle Pleistocene) - 'A'ā and pāhoehoe alkalic basalt (46.4$46.9 \% \mathrm{SiO}_{2} ; 0.60-0.65 \% \mathrm{~K}_{2} \mathrm{O}$ ) lava flows, moderate relief; pressure ridges. Contains phenocrysts of plagioclase $(2-5 \%, \leq 15 \mathrm{~mm})$ and olivine $(\leq 1 \%, \leq 3 \mathrm{~mm})$. Exposed over $12.4 \mathrm{~km}^{2}$; two branching lava-flow lobes, northern and southern, reach at least $4.6 \mathrm{~km}$ and at least 3.7 


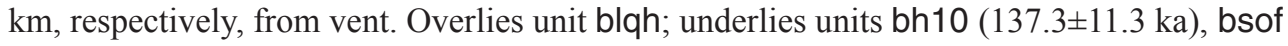
$(24.4 \pm 1.3 \mathrm{ka})$, and hlh $(154.8 \pm 5.5 \mathrm{ka})[\mathrm{B} 2]$

buri Basalt of Upper Ar Ritajah (middle Pleistocene) —Pāhoehoe basaltic lava flows, very subdued relief; associated scoria cone. Exposed over $1.1 \mathrm{~km}^{2}$; lava flows reach at least $1.6 \mathrm{~km}$ from vent. Underlies unit buru [F2]

buru

busi

bwh8

hma

hmk

hmo

masu

$\mathrm{mmu}$

mmy

murr

Basalt of Umm Rutaj (middle Pleistocene) - ' $\mathrm{A}$ 'ā and pāhoehoe alkalic basalt (46.6-46.7\% $\mathrm{SiO}_{2}$; $0.92-0.94 \% \mathrm{~K}_{2} \mathrm{O}$ ) lava flows, moderate relief; associated 1.3-km-long, elongate scoria-cone complex has five craters. Contains phenocrysts of plagioclase $(5 \%, \leq 50 \mathrm{~mm})$ and olivine $(1-2 \%, \leq 2 \mathrm{~mm})$. Exposed over $25.2 \mathrm{~km}^{2}$; lava flows reach at least $8.8 \mathrm{~km}$ from vent. Overlies units bahu, bmuf, bmus, bnh, bsah (401.6 $\pm 9.8 \mathrm{ka})$, bsj, and buri; underlies units badh $(208.9 \pm 16.9 \mathrm{ka})$, bns, and twa (39.2 $\pm 1.6 \mathrm{ka})[\mathrm{F} 2]$

Basalt of Upper Sha'ib Iskabah (middle Pleistocene) - 'A'āa and pāhoehoe basaltic lava flows, very subdued relief; associated scoria-cone complex. Exposed over only $0.3 \mathrm{~km}^{2}$; lava flows

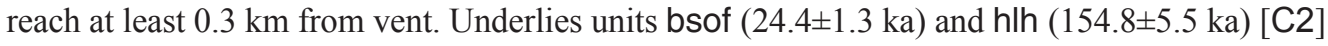

Basalt west of Hill 870 (middle Pleistocene) - 'A' $\bar{a}$ and pāhoehoe basaltic lava flows, moderate relief; associated partly collapsed scoria cone. Exposed over $1.1 \mathrm{~km}^{2}$; lava flows reach at least $2.3 \mathrm{~km}$ from vent. Underlies units bjr (207.3 $\pm 8.4 \mathrm{ka})$ and bsf $(217.5 \pm 6.7 \mathrm{ka})$ [D1]

Hawaiite of Al Malsa (middle Pleistocene) - ' $A$ '‘a and pāhoehoe hawaiite (48.1-48.2\% $\mathrm{SiO}_{2} ; 1.37-$ $1.38 \% \mathrm{~K}_{2} \mathrm{O}$ ) lava flows, rough to moderately rough relief; moderately well-defined pressure ridges, channels, and levees; two associated scoria cones span $3.8 \mathrm{~km}$. Contains phenocrysts of plagioclase $(<1 \%, \leq 10 \mathrm{~mm})$. Exposed over $23.8 \mathrm{~km}^{2}$; lava flows reach at least $4.0 \mathrm{~km}$ from vent. Overlies units bh82 (507.4 $\pm 38.3 \mathrm{ka})$, blsa (346.9 $\pm 9.9 \mathrm{ka})$, and bups; underlies units bdy (139.2 $\pm 11.3 \mathrm{ka})$, bla (1256 C.E.), bnof ( $24.4 \pm 1.3 \mathrm{ka})$, and bza; flowed around older unit bhb $(246.4 \pm 25.0 \mathrm{ka}) .{ }^{40} \mathrm{Ar} /{ }^{39} \mathrm{Ar}$ age, $220.5 \pm 10.9 \mathrm{ka}[\mathrm{A} 1, \mathrm{~A} 2, \mathrm{~B} 1, \mathrm{~B} 2]$

Hawaiite of Mukhayar (middle Pleistocene) - Pāhoehoe and ' $\mathrm{a}$ 'ā hawaiite (47.2-48.2\% $\mathrm{SiO}_{2}$; $1.30-1.39 \% \mathrm{~K}_{2} \mathrm{O}$ ) lava flows, moderate to subdued relief. Vent was destroyed by eruption of unit tef $(88.0 \pm 1.8 \mathrm{ka})$. Contains phenocrysts of plagioclase $(2-3 \%, \leq 15 \mathrm{~mm})$ and olivine $(<1 \%$, $\leq 1 \mathrm{~mm}$ ). Exposed over $4.5 \mathrm{~km}^{2}$; lava flows reach $8.4 \mathrm{~km}$ from vent area. Overlies units bqar, hhil (490.1 $\pm 4.6 \mathrm{ka})$, masu $(252.2 \pm 2.7 \mathrm{ka})$, and mzy (410.3 $\pm 3.4 \mathrm{ka})$; underlies units mmk $(114.4 \pm 8.5 \mathrm{ka})$ and tef $(88.0 \pm 1.8 \mathrm{ka}) .{ }^{40} \mathrm{Ar} /{ }^{39} \mathrm{Ar}$ ages, $238.9 \pm 4.8 \mathrm{ka}, 255.1 \pm 9.3 \mathrm{ka}, 265.9 \pm 7.4 \mathrm{ka}$; eruption age, $248.2 \pm 8.3 \mathrm{ka}$ (weighted mean age) [E2, F2]

Hawaiite of Mouteen (middle Pleistocene) - 'A'ā and pāhoehoe hawaiite and mugearite (47.9-48.4\% $\mathrm{SiO}_{2} ; 1.46-1.63 \% \mathrm{~K}_{2} \mathrm{O}$ ) lava flows, moderately subdued relief; associated partly exposed scoria cone. Contains phenocrysts of plagioclase $(\leq 1 \%, \leq 10 \mathrm{~mm})$ and olivine $(<1 \%, \leq 5 \mathrm{~mm})$. Part of unit's lava flows are uplifted by lava domes of units tma $(121.5 \pm 1.4 \mathrm{ka})$ and tmo $(31.9 \pm 2.1 \mathrm{ka})$. Exposed over $1.1 \mathrm{~km}^{2}$; lava flows reach at least $2.9 \mathrm{~km}$ from vent. Overlies units bmt and oba (242.8 $\left.\pm 2.4 \mathrm{ka}\right)$; underlies units tma $(121.5 \pm 1.4 \mathrm{ka})$ and tmo $(31.9 \pm 2.1 \mathrm{ka}) .{ }^{40} \mathrm{Ar} /{ }^{39} \mathrm{Ar}$ age, $239.0 \pm 4.1 \mathrm{ka}$ [C2, D2]

Mugearite of As Sumak (middle Pleistocene) - 'A' 'à and pāhoehoe mugearite (52.4\% $\mathrm{SiO}_{2}$; $2.13 \% \mathrm{~K}_{2} \mathrm{O}$ ) lava flows, moderately rough relief; associated 1.4-km-long, elongate vent zone has two scoria cones. Contains phenocrysts of plagioclase $(5 \%, \leq 15 \mathrm{~mm})$ and olivine $(2 \%, \leq 4$ $\mathrm{mm})$. Exposed over $5.1 \mathrm{~km}^{2}$; lava flows reach at least $2.6 \mathrm{~km}$ from vent. Overlies units basu $(453.4 \pm 12.8 \mathrm{ka})$, bqar, and busb $(302.3 \pm 14.8 \mathrm{ka})$; underlies units $\mathrm{hmk}(248.2 \pm 8.3 \mathrm{ka})$ and tef (88.0 $\pm 1.8 \mathrm{ka}) .{ }^{40} \mathrm{Ar} /{ }^{39} \mathrm{Ar}$ age, $252.2 \pm 2.7 \mathrm{ka}[\mathrm{E} 2, \mathrm{~F} 2]$

Mugearite of Al Mulaysa (middle Pleistocene) - 'A' $\mathrm{a}$ and pāhoehoe mugearite (51.9-52.2\% $\mathrm{SiO}_{2}$; $2.06-2.14 \% \mathrm{~K}_{2} \mathrm{O}$ ) lava flows, very rough relief; well-defined pressure ridges, channels, and levees; associated scoria cone. Contains phenocrysts of plagioclase $(<1-3 \%, \leq 10 \mathrm{~mm})$, olivine $(\leq 1 \%, \leq 2 \mathrm{~mm})$, and clinopyroxene $(<1 \%, \leq 1 \mathrm{~mm})$. Exposed over $15.2 \mathrm{~km}^{2}$; two branching lavaflow lobes, eastern and western, reach 10.0 and $5.6 \mathrm{~km}$, respectively, from vent. Overlies units

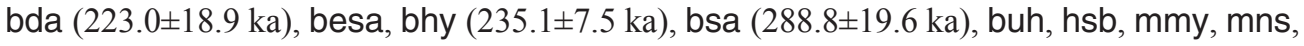
muq (385.6 $\pm 12.6 \mathrm{ka})$, and osa; underlies unit hd2. ${ }^{40} \mathrm{Ar} /{ }^{39} \mathrm{Ar}$ ages, $200.4 \pm 28.1 \mathrm{ka}, 211.9 \pm 3.5 \mathrm{ka}$, $220.6 \pm 5.1 \mathrm{ka}, 226.8 \pm 3.4 \mathrm{ka}$; eruption age, $219.6 \pm 4.0 \mathrm{ka}$ (weighted mean age) [D2]

Mugearite of Murayyikh (middle Pleistocene) - 'A $A$ a and pāhoehoe mugearite lava flows, rough relief; associated 0.5 -km-long, elongate scoria cone. Exposed over only $0.8 \mathrm{~km}^{2}$; lava flows reach at least $0.5 \mathrm{~km}$ from vent. Underlies units bda $(223.0 \pm 18.9 \mathrm{ka})$ and $\mathrm{mmu}(219.6 \pm 4.0 \mathrm{ka})$ [D2]

Mugearite of Umm Ar Rish (middle Pleistocene) - 'A'ā and pāhoehoe mugearite (49.8\% $\mathrm{SiO}_{2}$; $1.77-1.82 \% \mathrm{~K}_{2} \mathrm{O}$ ) lava flows, rough relief; pressure ridges, channels, and levees; associated partly collapsed scoria cone. Contains phenocrysts of plagioclase $(<1 \%, \leq 2 \mathrm{~mm})$ and olivine $(<1 \%, \leq 2 \mathrm{~mm})$. Exposed over $11.9 \mathrm{~km}^{2}$; lava flows reach at least $7.1 \mathrm{~km}$ from vent. 
Overlies units bash, bm1 (230.7 $\pm 4.4 \mathrm{ka})$, bss ( $461.9 \pm 4.9 \mathrm{ka})$, and oma; underlies units bda $(223.0 \pm 18.9 \mathrm{ka})$ and tg3 $(142.4 \pm 2.2 \mathrm{ka})$ [D1, D2]

Mugearite of Um Znabah 2 (middle Pleistocene) - 'A' $\bar{a}$ and pāhoehoe mugearite and benmoreite $\left(54.8-58.2 \% \mathrm{SiO}_{2} ; 2.97-3.73 \% \mathrm{~K}_{2} \mathrm{O}\right)$ lava flows, rough relief; well-defined pressure ridges, channels, and levees; associated scoria cone. Contains phenocrysts of plagioclase $(<1 \%, \leq 5 \mathrm{~mm})$ and olivine $(<1 \%, \leq 6 \mathrm{~mm})$. Exposed over $19.9 \mathrm{~km}^{2}$, unit consists of four branching lava-flow lobes: eastern lobe reaches $13.7 \mathrm{~km}$ from vent; northern lobe, $4.5 \mathrm{~km}$; western lobe, $5.5 \mathrm{~km}$; southwestern lobe, $4.4 \mathrm{~km}$. Overlies units bef, bsd ( $584.5 \pm 10.4 \mathrm{ka})$, buj, busb ( $302.3 \pm 14.8 \mathrm{ka})$, bush, mss

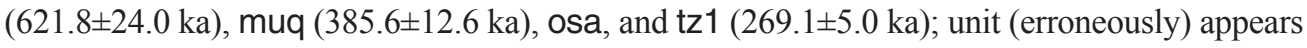
to overlie younger unit tz2 (121.6 $\pm 1.8 \mathrm{ka})$ because it has been uplifted by younger unit's dome; underlies units tef $(88.0 \pm 1.8 \mathrm{ka})$ and tg4 $(84.3 \pm 1.6 \mathrm{ka}) .{ }^{40} \mathrm{Ar} /{ }^{39} \mathrm{Ar}$ ages, $183.7 \pm 2.8 \mathrm{ka}, 191.1 \pm 4.6$ ka, $195.1 \pm 1.8 \mathrm{ka}, 197.8 \pm 2.2 \mathrm{ka}, 198.6 \pm 5.8 \mathrm{ka}$; eruption age, $195.9 \pm 1.3 \mathrm{ka}$ (weighted mean age, calculated using four of five ages [excluding $183.7 \pm 2.8 \mathrm{ka}$ ]); paleomagnetic similarities indicate

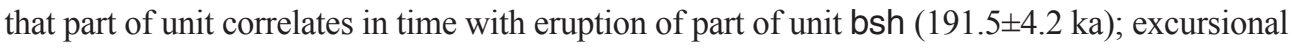
remanent-magnetic directions indicate that unit erupted during Iceland Basin excursion [D2, E2]

Benmoreite of Al Bayadah (middle Pleistocene) - Poorly sorted lava and ash deposit of benmoreite composition $\left(57.7-58.3 \% \mathrm{SiO}_{2} ; 3.49-3.59 \% \mathrm{~K}_{2} \mathrm{O}\right)$; emplaced as hummocky debris avalanche. Contains clinopyroxene phenocrysts $(1 \%, \leq 1 \mathrm{~mm})$. Prior to development of debris avalanche, vent was located where unit bm2 is now. Exposed over $4.8 \mathrm{~km}^{2}$; debris avalanche is at least $3.7 \mathrm{~km}$ long.

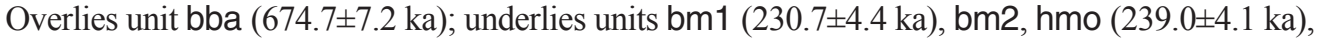
$\mathrm{mma}(154.0 \pm 8.3 \mathrm{ka})$, and tmo $(31.9 \pm 2.1 \mathrm{ka}) .{ }^{40} \mathrm{Ar}{ }^{\beta 9} \mathrm{Ar}$ eruption age, $242.8 \pm 2.4 \mathrm{ka}$ [D2]

oma

bash

bau

bd3

bh86

bhag

Benmoreite of Al Malsaa (middle Pleistocene) - Block-and-ash-flow deposit of benmoreite and trachyte $\left(59.5-60.1 \% \mathrm{SiO}_{2} ; 3.97-4.10 \% \mathrm{~K}_{2} \mathrm{O}\right)$ juvenile clasts, subdued relief. Aphyric. Exposed over only $0.4 \mathrm{~km}^{2}$; block-and-ash-flow deposit is at least $1.0 \mathrm{~km}$ long. Underlies units bm1 (230.7 $\pm 4.4 \mathrm{ka}), \mathrm{hm} 3$, and murr [D2]

\section{Eruptive Stage 7 (260 to $323 \mathrm{ka}$ )}

Basalt of Ash Shamali (middle Pleistocene) - Pāhoehoe basaltic lava flows, subdued relief. Exposed over $2.4 \mathrm{~km}^{2}$; lava flows reach at least $2.1 \mathrm{~km}$ from vent. Overlies units bada, bbsh, and bss (461.9 $\pm 4.9 \mathrm{ka})$; underlies units bms $(59.1 \pm 5.7 \mathrm{ka})$, mma (154.0 $\pm 8.3 \mathrm{ka})$, and murr [D1] Basalt of An Nughayr (middle Pleistocene) - Pāhoehoe and 'a'ā tholeiitic and alkalic basalt (46.8$46.9 \% \mathrm{SiO}_{2} ; 0.43-0.76 \% \mathrm{~K}_{2} \mathrm{O}$ ) lava flows, moderately rough relief; well-defined pressure ridges and associated 1.0-km-long, elongate, partly collapsed scoria cone. Contains phenocrysts of plagioclase $(1 \%, \leq 50 \mathrm{~mm})$ and olivine $(10 \%, \leq 7 \mathrm{~mm})$. Exposed over $4.4 \mathrm{~km}^{2}$; lava flows reach at least $3.2 \mathrm{~km}$ from vent. Underlies units bms (59.1 $\pm 5.7 \mathrm{ka})$, bsk, and bun (105.0 $\pm 8.6 \mathrm{ka})$. Paleomagnetic similarities indicate that age is similar to that of unit bhu (285.1 $\pm 6.6 \mathrm{ka})$; excursional remanent-magnetic directions indicate that unit erupted during Kolbeinsey Ridge excursion [B1, C1]

Basalt of Dabaa 3 (middle Pleistocene) - 'A'ā and pāhoehoe alkalic basalt (47.8-48.1\% $\mathrm{SiO}_{2}$; $0.88-0.91 \% \mathrm{~K}_{2} \mathrm{O}$ ) lava flows, rough to moderately rough relief; associated scoria cone. Contains phenocrysts of plagioclase $(1-2 \%, \leq 12 \mathrm{~mm})$ and olivine $(2-3 \%, \leq 6 \mathrm{~mm})$. Includes 0.8-km-diameter cryptodome that has uplifted juvenile lavas of this unit and unit muq $(385.6 \pm 12.6 \mathrm{ka})$. Exposed over $19.6 \mathrm{~km}^{2}$; lava flows reach $10.6 \mathrm{~km}$ from vent. Overlies units bjn $(512.8 \pm 9.3 \mathrm{ka})$, muq $(385.6 \pm 12.6 \mathrm{ka})$, and og4 $(316.4 \pm 2.1 \mathrm{ka})$; underlies units $\mathrm{mz2}(195.9 \pm 1.3 \mathrm{ka})$, tef $(88.0 \pm 1.8 \mathrm{ka})$, and tg4 $(84.3 \pm 1.6 \mathrm{ka}) .{ }^{40} \mathrm{Ar} /{ }^{39} \mathrm{Ar}$ ages, $300.0 \pm 6.1 \mathrm{ka}$, $318.1 \pm 7.1 \mathrm{ka}$; eruption age, $307.7 \pm 4.6 \mathrm{ka}$ (weighted mean age) [D2, E2]

Basalt of Hill 865 (middle Pleistocene) —Pāhoehoe and 'a 'āa alkalic basalt (46.2-46.7\% $\mathrm{SiO}_{2} ; 0.81-$ $0.95 \% \mathrm{~K}_{2} \mathrm{O}$ ) lava flows, rough relief; pressure ridges, channels, and levees; associated $0.6-\mathrm{km}$ long, elongate scoria cone has three craters. Contains phenocrysts of plagioclase $(1-10 \%, \leq 10$ $\mathrm{mm}$ ) and olivine ( $1-2 \%, \leq 8 \mathrm{~mm})$. Exposed over $42.4 \mathrm{~km}^{2}$; lava flows reach $14.5 \mathrm{~km}$ from vent.

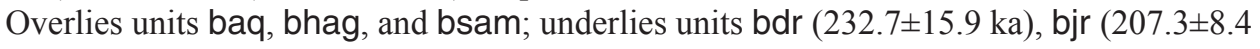
ka), bsf (217.5 $\pm 6.7 \mathrm{ka})$, and bso. ${ }^{40} \mathrm{Ar} /{ }^{39} \mathrm{Ar}$ ages, $255.6 \pm 30.5 \mathrm{ka}, 308.2 \pm 26.7 \mathrm{ka}$; eruption age, $285.4 \pm 20.1 \mathrm{ka}$ (weighted mean age) [D1, E1]

Basalt of Hilayyat Ghuwayshiyah (middle Pleistocene) - 'A' $\bar{a}$ and pāhoehoe alkalic basalt (46.2$47.7 \% \mathrm{SiO}_{2} ; 0.93-1.10 \% \mathrm{~K}_{2} \mathrm{O}$ ) lava flows, rough relief; pressure ridges, channels, and levees; associated $0.6-\mathrm{km}$-long, elongate scoria-cone complex. Contains phenocrysts of plagioclase $(1-3 \%, \leq 3 \mathrm{~mm})$ and olivine $(1-4 \%, \leq 3 \mathrm{~mm})$. Exposed over $37.1 \mathrm{~km}^{2}$; lava flows reach $14.9 \mathrm{~km}$ from vent. Overlies units baq, bdg, bju, bqaq, bri (438.9 $\pm 21.0 \mathrm{ka})$, bswu, and busb (302.3 \pm 14.8 ka); underlies units bh86 (285.4 $\pm 20.1 \mathrm{ka})$, bmd, and bml (222.2 $\pm 5.8 \mathrm{ka})$ [E1, F1, F2] 
Basalt of Al Humayra (middle Pleistocene) — Pāhoehoe and ' $\mathrm{a}$ 'ā basaltic lava flows, moderate to rough relief; associated partly collapsed scoria cone. Exposed over $3.1 \mathrm{~km}^{2}$; lava flows reach at least $1.6 \mathrm{~km}$ from vent. Overlies units bgh and bmy $(660.4 \pm 13.4 \mathrm{ka})$; underlies unit hd2 [E2]

Basalt of Al Huzaym (middle Pleistocene) - Pāhoehoe alkalic and tholeiitic basalt (46.4 47.6\% $\mathrm{SiO}_{2} ; 0.28-0.84 \% \mathrm{~K}_{2} \mathrm{O}$ ) lava flows, very subdued relief; associated shield volcano has summit vent. Contains phenocrysts of plagioclase $(<1-4 \%, \leq 1 \mathrm{~mm})$ and olivine $(4-15 \%, \leq 7 \mathrm{~mm})$. Exposed over $26.1 \mathrm{~km}^{2}$; lava flows reach at least $9.6 \mathrm{~km}$ from vent. Overlies units bhg $(382.5 \pm 5.8 \mathrm{ka})$ and bqu; underlies units bjs, bsh (191.5 $\pm 4.2 \mathrm{ka})$, bsk, and bun $(105.0 \pm 8.6 \mathrm{ka}) .{ }^{40} \mathrm{Ar} /{ }^{39} \mathrm{Ar}$ age, $285.1 \pm 6.6 \mathrm{ka}$; paleomagnetic similarities indicate that unit correlates in time with eruption of unit bau; excursional remanent-magnetic directions indicate unit erupted during Kolbeinsey Ridge excursion [A1, B1]

bmk

Basalt of Mukhayar (middle Pleistocene) — ' $\mathrm{A}$ 'ā and pāhoehoe alkalic basalt $\left(46.7 \% \mathrm{SiO}_{2} ; 0.96 \%\right.$ $\left.\mathrm{K}_{2} \mathrm{O}\right)$ lava flows, moderately subdued relief. Contains phenocrysts of plagioclase $(2 \%, \leq 20 \mathrm{~mm})$ and olivine $(7-9 \%, \leq 8 \mathrm{~mm})$. Exposed over $8.8 \mathrm{~km}^{2}$; lava flows reach at least $8.1 \mathrm{~km}$ from vent. Flowed around margins of older unit bsou; underlies units bme, bns, and mmk (114.4 \pm 8.5 ka). ${ }^{40} \mathrm{Ar} /{ }^{39} \mathrm{Ar}$ age, $261.3 \pm 19.1 \mathrm{ka}[\mathrm{F} 2]$

bqaq Basalt of Qa Al Qina'ah (middle Pleistocene) — 'A' $\mathrm{a}$ and pāhoehoe basaltic lava flows, subdued relief; associated scoria cone. Exposed over $9.1 \mathrm{~km}^{2}$; lava flows reach at least $4.9 \mathrm{~km}$ from vent. Overlies unit bsaw; underlies units bhag and bml $(222.2 \pm 5.8 \mathrm{ka})$ [E1, F1]

Basalt of Al Shathaa (middle Pleistocene) — 'A' $\mathrm{a}$ and pāhoehoe alkalic basalt $\left(46.0 \% \mathrm{SiO}_{2} ; 0.72 \%\right.$ $\mathrm{K}_{2} \mathrm{O}$ ) lava flows, subdued relief; associated $0.7-\mathrm{km}$-long, elongate and partly collapsed scoriacone complex has spatter ramparts. Contains olivine phenocrysts $(2 \%, \leq 3 \mathrm{~mm})$. Exposed over $1.5 \mathrm{~km}^{2}$; lava flows reach at least $4.5 \mathrm{~km}$ from vent. Cut by same normal fault that displaced unit besa by $10 \mathrm{~m}$. Overlies units muq $(385.6 \pm 12.6 \mathrm{ka})$ and osa; underlies units besa and mmu (219.6 $\pm 4.0 \mathrm{ka}) .{ }^{40} \mathrm{Ar} /{ }^{39} \mathrm{Ar}$ age, $288.8 \pm 19.6 \mathrm{ka}[\mathrm{D} 2]$

bssu

Basalt south of As Sumak (middle Pleistocene) — 'A' $\bar{a}$ and pāhoehoe alkalic basalt (46.9\% $\mathrm{SiO}_{2}$; $0.86 \% \mathrm{~K}_{2} \mathrm{O}$ ) lava flows, subdued relief; associated partly collapsed scoria cone. Contains phenocrysts of plagioclase $(1 \%, \leq 15 \mathrm{~mm})$ and olivine $(3 \%, \leq 5 \mathrm{~mm})$. Exposed over $12.1 \mathrm{~km}^{2}$; lava flows reach at least $6.6 \mathrm{~km}$ from vent. Overlies units basu $(453.4 \pm 12.8 \mathrm{ka})$ and bsj; underlies units badh $(208.9 \pm 16.9 \mathrm{ka})$ and twa $(39.2 \pm 1.6 \mathrm{ka}) .{ }^{40} \mathrm{Ar} /{ }^{39} \mathrm{Ar}$ age, $313.9 \pm 11.3 \mathrm{ka}$ [E2, F2]

Basalt of Umm Suyuf (middle Pleistocene) - 'A'ā and pāhoehoe alkalic basalt (46.3-46.6\% $\mathrm{SiO}_{2}$; $0.53-0.90 \% \mathrm{~K}_{2} \mathrm{O}$ ) lava flows, moderately subdued relief; associated partly collapsed scoria cone. Contains phenocrysts of plagioclase $(2 \%, \leq 20 \mathrm{~mm})$ and olivine $(1-2 \%, \leq 4 \mathrm{~mm})$. Exposed over $2.9 \mathrm{~km}^{2}$; lava flows reach at least $3.0 \mathrm{~km}$ from vent. Overlies unit bjab $(324.7 \pm 29.3 \mathrm{ka})$; underlies unit bsf $(217.5 \pm 6.7 \mathrm{ka})$ [D1]

busb Basalt of Al Usbu'ah (middle Pleistocene) — 'A' $\bar{a}$ and pāhoehoe alkalic and tholeiitic basalt and hawaiite (47.3-49.2\% $\left.\mathrm{SiO}_{2} ; 0.48-1.37 \% \mathrm{~K}_{2} \mathrm{O}\right)$ lava flows, rough relief; channels and levees; associated partly collapsed scoria cone. Contains phenocrysts of plagioclase $(\leq 1 \%, \leq 3 \mathrm{~mm})$ and olivine $(\leq 1 \%, \leq 2 \mathrm{~mm})$. Exposed over $25.8 \mathrm{~km}^{2}$; lava flows reach at least $16.4 \mathrm{~km}$ from vent. Overlies units basu (453.4 $\pm 12.8 \mathrm{ka})$, bdg, bgh, bqi, buj, and buph (510.8 $\pm 29.4 \mathrm{ka})$; underlies units bhag, bml $(222.2 \pm 5.8 \mathrm{ka})$, masu $(252.2 \pm 2.7 \mathrm{ka})$, and $\mathrm{mz} 2(195.9 \pm 1.3 \mathrm{ka}) .{ }^{40} \mathrm{Ar} /{ }^{39} \mathrm{Ar}$ ages, $267.0 \pm 16.7$ ka, 308.5 $\pm 7.0 \mathrm{ka}$; eruption age, $302.3 \pm 14.8 \mathrm{ka}$ (weighted mean age) [E1, E2, F1, F2]

Basalt of Yalla (middle Pleistocene) -Minor alkalic basalt (47.9-48.0\% $\mathrm{SiO}_{2} ; 1.02 \% \mathrm{~K}_{2} \mathrm{O}$ ) lava flows; associated scoria cone. Contains phenocrysts of plagioclase $(1 \%, \leq 2 \mathrm{~mm})$ and olivine $(<1 \%, \leq 1 \mathrm{~mm})$. Exposed over only $0.5 \mathrm{~km}^{2}$; lava flows reach at least $1.2 \mathrm{~km}$ from vent. Flowed around older unit oju (424.2 $\pm 1.8 \mathrm{ka}, 437.6 \pm 4.3 \mathrm{ka})$; underlies units bhy $(235.1 \pm 7.5 \mathrm{ka}), \operatorname{tg} 2$ $(93.8 \pm 2.1 \mathrm{ka})$, and tg3 (142.4 $\pm 2.2 \mathrm{ka})[\mathrm{D} 2]$

Benmoreite of Gura 4 (middle Pleistocene) - Benmoreite (58.3-58.4\% $\left.\mathrm{SiO}_{2} ; 3.58-3.64 \% \mathrm{~K}_{2} \mathrm{O}\right)$ lava flows; exposed in crater wall of unit tg4 $(84.3 \pm 1.6 \mathrm{ka})$. Contains phenocrysts of plagioclase and K-rich feldspars (anorthoclase and sanidine) (together, $3 \%, \leq 5 \mathrm{~mm})$, fayalitic olivine $(<1 \%, \leq 1$ $\mathrm{mm})$, and clinopyroxene $(1 \%, \leq 1 \mathrm{~mm})$. Overlies very sparsely exposed, older unmapped benmoreite lava $\left({ }^{40} \mathrm{Ar} /{ }^{39} \mathrm{Ar}\right.$ age, $\left.1,137.9 \pm 3.1 \mathrm{ka}\right)$; underlies units bd3 (307.7 $\left.\pm 4.6 \mathrm{ka}\right)$ and tg4 (84.3 $\left.\pm 1.6 \mathrm{ka}\right)$. ${ }^{40} \mathrm{Ar} /{ }^{39} \mathrm{Ar}$ ages, $313.0 \pm 3.1 \mathrm{ka}, 319.1 \pm 2.8 \mathrm{ka}$; eruption age, 316.4 $\pm 2.1 \mathrm{ka}$ (weighted mean age) [E2] $(195.9 \pm 1.3 \mathrm{ka})$ and $\operatorname{tg} 4(84.3 \pm 1.6 \mathrm{ka}) .{ }^{40} \mathrm{Ar} /{ }^{39} \mathrm{Ar}$ ages, $268.1 \pm 6.6 \mathrm{ka}, 270.4 \pm 7.7 \mathrm{ka}$; eruption age, $269.1 \pm 5.0 \mathrm{ka}$ (weighted mean age) [E2] 
Basalt of Jabal (middle Pleistocene) — Pāhoehoe and ' $\mathrm{a}$ 'ā alkalic basalt $\left(46.6 \% \mathrm{SiO}_{2} ; 0.71 \% \mathrm{~K}_{2} \mathrm{O}\right)$ lava flows, subdued relief; associated $0.7-\mathrm{km}-\mathrm{long}$, elongate scoria-cone complex. Contains phenocrysts of plagioclase $(1 \%, \leq 10 \mathrm{~mm})$ and olivine $(3 \%, \leq 1 \mathrm{~mm})$. Exposed over $14.7 \mathrm{~km}^{2}$; lava flows reach at least $8.7 \mathrm{~km}$ from vent. Overlies unit bh83 $(505.1 \pm 10.3 \mathrm{ka})$; underlies units badb, bms (59.1 $\pm 5.7 \mathrm{ka})$, bqg $(215.2 \pm 6.9 \mathrm{ka})$, bsf $(217.5 \pm 6.7 \mathrm{ka})$, and bsuy. ${ }^{40} \mathrm{Ar} /{ }^{39} \mathrm{Ar}$ age, $324.7 \pm 29.3 \mathrm{ka}$ [D1]

Basalt of Lower Sahab (middle Pleistocene) - Pāhoehoe and 'a'ā alkalic basalt (46.3-47.5\% $\mathrm{SiO}_{2}$; $0.62-0.94 \% \mathrm{~K}_{2} \mathrm{O}$ ) lava flows, moderately subdued relief; minor pressure ridges; associated 1.4-kmlong, elongate vent complex has four scoria cones. Contains phenocrysts of plagioclase $(1 \%, \leq 15$ $\mathrm{mm}$ ) and olivine $(1-5 \%, \leq 4 \mathrm{~mm})$. Exposed over $19.0 \mathrm{~km}^{2}$; lava flows reach at least $10.7 \mathrm{~km}$ from vent. Overlies units bh82 (507.4 $\pm 38.3 \mathrm{ka})$, bsl, and buqa (1,069.6 $\pm 19.3 \mathrm{ka})$; underlies units bla (1256 C.E.), bnof (24.4 $\pm 1.3 \mathrm{ka})$, and hma $(220.5 \pm 10.9 \mathrm{ka}) .{ }^{40} \mathrm{Ar} /{ }^{39} \mathrm{Ar}$ age, $346.9 \pm 9.9 \mathrm{ka}$ [A1, A2]

bmu

Basalt of Al Mustarah (middle Pleistocene) - 'A' $\mathrm{a}$ and pāhoehoe alkalic basalt (47.1-47.4\% $\mathrm{SiO}_{2}$; $0.74-0.78 \% \mathrm{~K}_{2} \mathrm{O}$ ) lava flows, very subdued relief; associated $0.6-\mathrm{km}$-long, elongate scoria cone has two craters. Contains phenocrysts of plagioclase $(1-5 \%, \leq 20 \mathrm{~mm})$ and olivine $(1-10 \%$, $\leq 8 \mathrm{~mm}$ ). Conservative reconstruction indicates that unit is present over at least $31.4 \mathrm{~km}^{2}$; lava

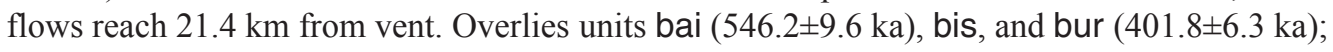
underlies units bsb and han2. ${ }^{40} \mathrm{Ar} /{ }^{39} \mathrm{Ar}$ age, $344.7 \pm 4.8 \mathrm{ka}[\mathrm{A} 1, \mathrm{~B} 1]$

Basalt south of Al Jufdirah (middle Pleistocene) —Pāhoehoe and minor 'a'ā tholeiitic basalt $\left(47.8 \% \mathrm{SiO}_{2} ; 0.33-0.39 \% \mathrm{~K}_{2} \mathrm{O}\right)$ lava flows, very subdued relief. Contains phenocrysts of plagioclase $(1 \%, \leq 1 \mathrm{~mm})$, olivine $(2-4 \%, \leq 3 \mathrm{~mm})$, and clinopyroxene $(1 \%, \leq 1 \mathrm{~mm})$. Exposed over $1.9 \mathrm{~km}^{2}$; lava flows reach at least $3.8 \mathrm{~km}$ from vent. Underlies units bssu $(313.9 \pm 11.3 \mathrm{ka})$, buru, and twa (39.2 $\pm 1.6 \mathrm{ka})$ [F2]

bsm Basalt of Sha'ib Murayyikh (middle Pleistocene) - 'A'ā and pāhoehoe alkalic basalt (46.1\% $\left.\mathrm{SiO}_{2} ; 0.77 \% \mathrm{~K}_{2} \mathrm{O}\right)$ lava flows, subdued relief. Contains olivine phenocrysts $(<1 \%, \leq 1 \mathrm{~mm})$. Exposed over $7.3 \mathrm{~km}^{2}$; lava flows reach at least $7.6 \mathrm{~km}$ from vent. Overlies units bat, bmsm $(552.8 \pm 19.6 \mathrm{ka})$, bmy $(660.4 \pm 13.4 \mathrm{ka})$, bss $(461.9 \pm 4.9 \mathrm{ka})$, and bwhu; underlies units bjr (207.3 $\pm 8.4 \mathrm{ka})$ and hd2 [D1, D2, E1, E2]

\section{Eruptive Stage 9 (360 to $460 \mathrm{ka}$ )}

Basalt of Abar Al Julud (middle Pleistocene) - Pāhoehoe and 'a'ā basaltic lava flows, very subdued relief; associated scoria cone. Exposed over $4.5 \mathrm{~km}^{2}$; lava flows reach $4.7 \mathrm{~km}$ from vent. Underlies units baq, brb, and brw [D1, E1]

Basalt of Al Qurdi (middle Pleistocene)—Pāhoehoe and 'a'ā alkalic basalt (47.8\% $\mathrm{SiO}_{2} ; 0.78 \%$ $\mathrm{K}_{2} \mathrm{O}$ ) lava flows, subdued relief; associated scoria cone has five craters. Contains phenocrysts of plagioclase $(1 \%, \leq 5 \mathrm{~mm})$ and olivine $(2 \%, \leq 1 \mathrm{~mm})$. Exposed over $24.6 \mathrm{~km}^{2}$; lava flows reach $9.3 \mathrm{~km}$ from vent. Overlies units baaj, brb, brw, and bsam; underlies units bh86 (285.4 \pm 20.1 $\mathrm{ka})$, bhag, and bri (438.9 $21.0 \mathrm{ka})$ [E1]

Basalt of As Sumak (middle Pleistocene) - Pāhoehoe and minor 'a āa alkalic basalt (46.5\% $\mathrm{SiO}_{2}$; $0.75-0.77 \% \mathrm{~K}_{2} \mathrm{O}$ ) lava flows, moderately rough relief; associated heavily eroded scoria-cone complex. Contains phenocrysts of plagioclase $(1-4 \%, \leq 20 \mathrm{~mm})$ and olivine $(1-8 \%, \leq 5 \mathrm{~mm})$. Exposed over $18.8 \mathrm{~km}^{2}$; lava flows reach $9.3 \mathrm{~km}$ from vent. Overlies units bqi and bdg; underlies units bawa,

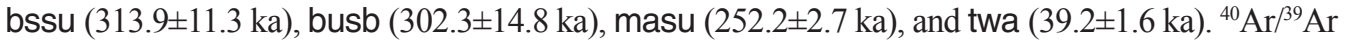
ages, $444.4 \pm 6.8 \mathrm{ka}, 471.6 \pm 9.7 \mathrm{ka}$; eruption age, $453.4 \pm 12.8 \mathrm{ka}$ (weighted mean age) [E2, F2]

bay Basalt of Atiyah (middle Pleistocene) - Pāhoehoe alkalic basalt (47.9-48.0\% $\mathrm{SiO}_{2} ; 1.15-1.16 \%$ $\mathrm{K}_{2} \mathrm{O}$ ) lava flows, subdued relief. Aphyric. Exposed over $9.3 \mathrm{~km}^{2}$; lava flows reach at least 4.5

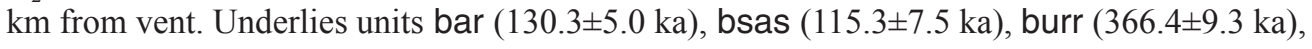
and hlh $(154.8 \pm 5.5 \mathrm{ka})$ [C2]

bdg Basalt of Duwayghir (middle Pleistocene)—Pāhoehoe and ' $a$ 'āa alkalic basalt $\left(47.3 \% \mathrm{SiO}_{2} ; 0.83 \%\right.$ $\mathrm{K}_{2} \mathrm{O}$ ) lava flows, subdued relief; associated 0.9-km-long, elongate scoria cone has three craters. Aphyric. Exposed over $6.6 \mathrm{~km}^{2}$; lava flows reach at least $3.1 \mathrm{~km}$ from vent. Underlies units basu $(453.4 \pm 12.8 \mathrm{ka})$, bhag, and busb $(302.3 \pm 14.8 \mathrm{ka})[\mathrm{E} 2, \mathrm{~F} 2]$

bduw

Basalt of Ad Duwayfi'ah (middle Pleistocene) - Pāhoehoe basaltic lava flows, very subdued relief. Exposed over $3.1 \mathrm{~km}^{2}$; lava flows reach at least $3.9 \mathrm{~km}$ from vent. Overlies unit brag; underlies units badb and bsf $(217.5 \pm 6.7 \mathrm{ka})[\mathrm{D} 1]$ 
Basalt of Hill 870 (middle Pleistocene) —Pāhoehoe basaltic lava flows, subdued relief; associated scoria cone. Exposed over only $0.3 \mathrm{~km}^{2}$; lava flows reach at least $0.7 \mathrm{~km}$ from vent. Underlies unit bsf $(217.5 \pm 6.7 \mathrm{ka})[\mathrm{D} 1]$

Basalt of Al Harrah Al Gharbiyah (middle Pleistocene) —Pāhoehoe and minor 'a'āa alkalic basalt $\left(45.2-45.7 \% \mathrm{SiO}_{2} ; 0.87-0.95 \% \mathrm{~K}_{2} \mathrm{O}\right)$ lava flows, subdued relief. Contains phenocrysts of plagioclase $(<1 \%, \leq 10 \mathrm{~mm})$ and olivine $(<1-2 \%, \leq 5 \mathrm{~mm})$. Exposed over $17.9 \mathrm{~km}^{2}$; lava flows reach at least $7.3 \mathrm{~km}$ from vent. Overlies unit bqu; underlies unit bhu $(285.1 \pm 6.6 \mathrm{ka}) .{ }^{40} \mathrm{Ar} /{ }^{39} \mathrm{Ar}$ age, $382.5 \pm 5.8 \mathrm{ka}$; paleomagnetic similarities indicate that unit correlates in time with eruption of unit bpr $(378.8 \pm 10.0 \mathrm{ka})[\mathrm{A} 1]$

bju Basalt of Al Jurb (middle Pleistocene) - 'A'ā and pāhoehoe basaltic lava flows, moderate relief, as well as associated scoria cone. Exposed over $1.6 \mathrm{~km}^{2}$; lava flows reach at least $2.1 \mathrm{~km}$ from vent. Overlies unit bri $(438.9 \pm 21.0 \mathrm{ka})$; underlies unit bhag [F1]

bmuf

Basalt of Al Mufayriq (middle Pleistocene) - 'A'ā and pāhoehoe alkalic and tholeiitic basalt (46.9-47.4\% $\mathrm{SiO}_{2} ; 0.33-0.49 \% \mathrm{~K}_{2} \mathrm{O}$ ) lava flows, moderate relief; associated scoria cone. Contains phenocrysts of plagioclase $(<1-5 \%, \leq 15 \mathrm{~mm})$ and olivine $(\leq 1 \%, \leq 4 \mathrm{~mm})$. Exposed over an area of $59.2 \mathrm{~km}^{2}$; two branching lava-flow lobes, northern and southern, reach 18.3 and 14.7 $\mathrm{km}$, respectively, from vent. Overlies units brum, busa, and busq; underlies units bns, bri $(438.9 \pm 21.0 \mathrm{ka})$, buak, and buru [F1, F2]

bmus

bnh

bni

bnj

bpr

bqi

bqr

brb

brh

Basalt of Muslimah (middle Pleistocene) — Pāhoehoe basaltic lava flows, very subdued relief; associated scoria cone. Exposed over $2.6 \mathrm{~km}^{2}$; lava flows reach at least $0.7 \mathrm{~km}$ from vent. Underlies unit buru [F2]

Basalt of Al Negea'ah (middle Pleistocene) - 'A'āa and pāhoehoe basaltic lava flows, subdued relief; associated 2.2-km-long, elongate scoria-cone complex consists of multiple cones and craters. Exposed over $14.5 \mathrm{~km}^{2}$; lava flows reach at least $5.6 \mathrm{~km}$ from vent. Overlies units bhin and bsou; underlies units bsah (401.6 $\pm 9.8 \mathrm{ka})$ and buru [F2]

Basalt north of Iskabah (middle Pleistocene) - 'A' $\mathrm{a}$ and pāhoehoe alkalic basalt (48.1-48.3\% $\mathrm{SiO}_{2} ; 1.00-1.17 \% \mathrm{~K}_{2} \mathrm{O}$ ) lava flows, very subdued relief; associated 0.8 -km-long, elongate scoriacone complex has four craters. Contains olivine phenocrysts $(1-2 \%, \leq 1 \mathrm{~mm})$. Exposed over $1.6 \mathrm{~km}^{2}$; lava flows reach at least $2.0 \mathrm{~km}$ from vent. Several ground cracks, which break lavaflow surface of unit, are interpreted to have formed during eruption of unit bsof $(24.4 \pm 1.3 \mathrm{ka})$. Underlies units bsi $(151.9 \pm 9.9 \mathrm{ka})$ and bsof $(24.4 \pm 1.3 \mathrm{ka}) .{ }^{40} \mathrm{Ar} /{ }^{39} \mathrm{Ar}$ age, $402.5 \pm 15.4 \mathrm{ka}$ [C2]

Basalt north of Al Jufdirah (middle Pleistocene) —Alkalic basalt (46.5-46.6\% $\mathrm{SiO}_{2} ; 0.85-0.89 \%$ $\mathrm{K}_{2} \mathrm{O}$ ) lava flows; exposed in crater wall of unit twa (39.2 $\left.\pm 1.6 \mathrm{ka}\right)$. Contains phenocrysts of plagioclase $(10 \%, \leq 4 \mathrm{~mm})$ and olivine $(5 \%, \leq 3 \mathrm{~mm})$. Exposed over only $0.4 \mathrm{~km}^{2}$. Underlies unit twa $(39.2 \pm 1.6 \mathrm{ka})[\mathrm{F} 2]$

Basalt of Powerline Road (middle Pleistocene) - 'A ' ‘ā and pāhoehoe alkalic basalt (46.5\% $\mathrm{SiO}_{2}$; $0.49 \% \mathrm{~K}_{2} \mathrm{O}$ ) lava flows, moderately subdued relief; associated scoria cone. Aphyric. Exposed over only $0.4 \mathrm{~km}^{2}$; lava flows reach at least $0.9 \mathrm{~km}$ from vent. Underlies unit bla (1256 C.E.). ${ }^{40} \mathrm{Ar} /{ }^{39} \mathrm{Ar}$ age, $378.8 \pm 10.0 \mathrm{ka}$; paleomagnetic similarities indicate that unit correlates in time with eruption of unit bhg (382.5 $\pm 5.8 \mathrm{ka})[\mathrm{A} 1]$

Basalt of Al Qirayy (middle Pleistocene) - 'A' ${ }^{\prime} \bar{a}$ and pāhoehoe basaltic lava flows, subdued relief; associated scoria cone. Exposed over $1.1 \mathrm{~km}^{2}$; lava flows reach at least $1.0 \mathrm{~km}$ from vent. Underlies units basu $(453.4 \pm 12.8 \mathrm{ka})$ and busb $(302.3 \pm 14.8 \mathrm{ka})$ [E2, F2]

Basalt of Quraydah (middle Pleistocene) - ' $\mathrm{A}$ 'a and pāhoehoe alkalic basalt (46.5-47.3\% $\mathrm{SiO}_{2}$; $\left.0.63-0.98 \% \mathrm{~K}_{2} \mathrm{O}\right)$ lava flows, very subdued relief. Contains phenocrysts of plagioclase $(<1-3 \%$, $\leq 10 \mathrm{~mm}$ ) and olivine $(<1-3 \%, \leq 2 \mathrm{~mm})$. Exposed over $9.0 \mathrm{~km}^{2}$; lava flows reach at least $5.4 \mathrm{~km}$ from vent. Overlies unit bai (546.2 $\pm 9.6 \mathrm{ka})$; underlies units bbd (223.4 $\pm 8.6 \mathrm{ka})$, bra, and bru [A1, B1]

Basalt of Rawd Al Baham (middle Pleistocene) - 'A' ${ }^{\prime} \bar{a}$ and pāhoehoe alkalic basalt (47.2\% $\mathrm{SiO}_{2}$; $1.06 \% \mathrm{~K}_{2} \mathrm{O}$ ) lava flows, very subdued relief; associated scoria cone. Aphyric. Exposed over $17.7 \mathrm{~km}^{2}$; lava flows reach $12.2 \mathrm{~km}$ from vent. Overlies unit baaj; underlies units baq, bri $(438.9 \pm 21.0 \mathrm{ka})$, and brw [E1, F1]

Basalt of Rahat (middle Pleistocene) - ' $\mathrm{A}$ 'ā and pāhoehoe alkalic basalt (45.7-47.0\% $\mathrm{SiO}_{2} ; 0.80$ $0.81 \% \mathrm{~K}_{2} \mathrm{O}$ ) lava flows, moderately rough relief. Contains phenocrysts of plagioclase (1-2\%, $\leq 5 \mathrm{~mm})$ and olivine $(<1-2 \%, \leq 3 \mathrm{~mm})$. Exposed over $3.2 \mathrm{~km}^{2}$; lava flows reach at least $1.6 \mathrm{~km}$ from vent. Overlies units bai ( $546.2 \pm 9.6 \mathrm{ka})$ and bqu; underlies units bbd (223.4 $\pm 8.6 \mathrm{ka})$, bnu $(131.2 \pm 8.3 \mathrm{ka})$, and bsh $(191.5 \pm 4.2 \mathrm{ka}) .{ }^{40} \mathrm{Ar} /{ }^{39} \mathrm{Ar}$ age, $411.5 \pm 5.9 \mathrm{ka}$; paleomagnetic similarities indicate that unit correlates in time with eruption of unit ozy (418.8 $\pm 1.9 \mathrm{ka})$; excursional remanent-magnetic directions indicate unit erupted during Weinen excursion [B1] 
Basalt of Ar Ritajah (middle Pleistocene) - ' $\mathrm{A}$ ' $\bar{a}$ and pāhoehoe alkalic basalt (47.1-47.2\% $\mathrm{SiO}_{2}$; $0.59-0.68 \% \mathrm{~K}_{2} \mathrm{O}$ ) lava flows, moderately rough relief. Contains phenocrysts of plagioclase $(<1 \%, \leq 10 \mathrm{~mm})$ and olivine $(<1-5 \%, \leq 1 \mathrm{~mm})$. Exposed over $27.2 \mathrm{~km}^{2}$; lava flows reach at least $14.9 \mathrm{~km}$ from vent. Overlies units baq, bmuf, brb, bswu, and busa; underlies units bhag, bju, bmd, and buak. ${ }^{40} \mathrm{Ar} /{ }^{39} \mathrm{Ar}$ age, $438.9 \pm 21.0 \mathrm{ka}[\mathrm{E} 1, \mathrm{~F} 1]$

brum

brw

bsah

bsam

bsaw

bsou

bswu

bte

buh

buj

bur

burr

busa

busq

Basalt of Ar Rumahiyah (middle Pleistocene) - ' $A$ 'ā and pāhoehoe basaltic lava flows, moderate relief; associated scoria cone. Exposed over $10.1 \mathrm{~km}^{2}$; lava flows reach at least $5.7 \mathrm{~km}$ from vent. Overlies unit busq; underlies unit bmuf [F1]

Basalt of Ruwawah (middle Pleistocene) - 'A' $' \bar{a}$ and pāhoehoe basaltic lava flows, very subdued relief; associated partly collapsed scoria cone. Exposed over only $0.9 \mathrm{~km}^{2}$; lava flows reach at least $1.4 \mathrm{~km}$ from vent. Overlies units baaj and brb; underlies unit baq [E1]

Basalt of Shi'ban Al Hulaysiwat (middle Pleistocene) - 'A'āa and pāhoehoe alkalic basalt (46.5$48.5 \% \mathrm{SiO}_{2} ; 0.92-1.20 \% \mathrm{~K}_{2} \mathrm{O}$ ) lava flows, subdued relief; associated 1.1-km-long, elongate scoria-cone complex. Contains phenocrysts of plagioclase $(2 \%, \leq 20 \mathrm{~mm})$ and olivine $(3-4 \%, \leq 8$ $\mathrm{mm}$ ). Exposed over $6.4 \mathrm{~km}^{2}$; lava flows reach at least $6.9 \mathrm{~km}$ from vent. Overlies units bnh and bsou; underlies units bahu, buru, and mmk $(114.4 \pm 8.5 \mathrm{ka}) .{ }^{40} \mathrm{Ar} /{ }^{39} \mathrm{Ar}$ age, $401.6 \pm 9.8 \mathrm{ka}$ [F2]

Basalt of Sha'ib Al Maqrin (middle Pleistocene) - 'A'ā and pāhoehoe basaltic lava flows, very subdued relief; associated scoria cone. Exposed over $10.9 \mathrm{~km}^{2}$; lava flows reach at least $10.6 \mathrm{~km}$ from vent. Underlies units baq, bh86 (285.4 $\pm 20.1 \mathrm{ka}), \mathrm{bml}(222.2 \pm 5.8 \mathrm{ka})$, bsf (217.5 $\pm 6.7 \mathrm{ka})$, and bso [D1, E1]

Basalt of Sha'ib Al Wuqayt (middle Pleistocene) - 'A'ā and pāhoehoe basaltic lava flows, very subdued relief; associated scoria cone. Exposed over only $0.5 \mathrm{~km}^{2}$; lava flows reach at least 0.8 $\mathrm{km}$ from vent. Underlies units bml $(222.2 \pm 5.8 \mathrm{ka})$ and bqaq [E1]

Basalt of Southwest (middle Pleistocene) - ' $\mathrm{A}$ ' $\bar{a}$ and pāhoehoe tholeiitic basalt $\left(47.1-47.2 \% \mathrm{SiO}_{2}\right.$; $\left.0.32 \% \mathrm{~K}_{2} \mathrm{O}\right)$ lava flows, moderately rough relief. Contains olivine phenocrysts $(1-5 \%, \leq 4 \mathrm{~mm})$. Exposed over only $12.6 \mathrm{~km}^{2}$; lava flows reach $12.8 \mathrm{~km}$ from vent. Underlies units bahu, bnh,

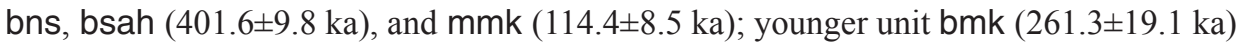
flowed around margin of this unit [F2]

Basalt of Sha'ib Al Wuqayyit (middle Pleistocene) - 'A'ā and pāhoehoe basaltic lava flows, very subdued relief. Exposed over $6.6 \mathrm{~km}^{2}$; lava flows reach at least $3.8 \mathrm{~km}$ from vent. Underlies units bhag and bri $(438.9 \pm 21.0 \mathrm{ka})$ [E1, F1]

Basalt of Abu Tunaydibah East (middle Pleistocene) - 'A'āa and pāhoehoe tholeiitic basalt (46.5-46.6\% $\mathrm{SiO}_{2} ; 0.30-0.43 \% \mathrm{~K}_{2} \mathrm{O}$ ) lava flows, very subdued relief; associated heavily eroded scoria-cone complex. Contains olivine phenocrysts $(1-5 \%, \leq 10 \mathrm{~mm})$. Exposed over $2.1 \mathrm{~km}^{2}$; lava flows reach at least $2.1 \mathrm{~km}$ from vent. Overlies unit btw $(497.5 \pm 37.5 \mathrm{ka})$; underlies units bqg $(215.2 \pm 6.9 \mathrm{ka})$ and bsy $(236.2 \pm 29.2 \mathrm{ka})$ [C1, D1]

Basalt of Umm Hamd (middle Pleistocene) - ' $\mathrm{A}$ 'ā and pāhoehoe alkalic basalt (48.5\% $\mathrm{SiO}_{2} ; 1.06 \%$ $\mathrm{K}_{2} \mathrm{O}$ ) lava flows; associated heavily eroded scoria-cone complex. Aphyric. Exposed over 1.5 $\mathrm{km}^{2}$. Underlies units bhy (235.1 $\left.\pm 7.5 \mathrm{ka}\right), \mathrm{mmu}(219.6 \pm 4.0 \mathrm{ka})$, and tg3 (142.4 $\left.\pm 2.2 \mathrm{ka}\right)$ [D2]

Basalt of Umm Ja'adat (middle Pleistocene) - 'A' $\mathrm{a}$ and pāhoehoe basaltic lava flows, subdued relief. Exposed over $6.5 \mathrm{~km}^{2}$; lava flows reach at least $3.3 \mathrm{~km}$ from vent. Overlies unit bsd (584.5 $\pm 10.4 \mathrm{ka})$; underlies units busb $(302.3 \pm 14.8 \mathrm{ka})$ and $\mathrm{mz2}(195.9 \pm 1.3 \mathrm{ka})$ [E2]

Basalt of Al Urayd (middle Pleistocene) - 'A' $' \bar{a}$ and pāhoehoe alkalic basalt $\left(46.6 \% \mathrm{SiO}_{2} ; 1.13 \%\right.$ $\left.\mathrm{K}_{2} \mathrm{O}\right)$ lava flows, very subdued relief. Contains plagioclase phenocrysts $(1-3 \%, \leq 10 \mathrm{~mm})$. Conservative reconstruction indicates that unit is present over at least $14.0 \mathrm{~km}^{2}$; lava flows reach at least $5.6 \mathrm{~km}$ from vent. Overlies units bha and bis; underlies units bdw $(25.6 \pm 16.2 \mathrm{ka})$, bmu (344.7 $\pm 4.8 \mathrm{ka})$, and bsu $(85.7 \pm 5.7 \mathrm{ka}) .{ }^{40} \mathrm{Ar} /{ }^{39} \mathrm{Ar}$ age, $401.8 \pm 6.3 \mathrm{ka}[\mathrm{A} 1]$

Basalt of Upper Abu Rimthah (middle Pleistocene) - 'A' $\bar{a}$ and pāhoehoe tholeiitic and alkalic basalt (46.9-47.9\% $\left.\mathrm{SiO}_{2} ; 0.28-0.79 \% \mathrm{~K}_{2} \mathrm{O}\right)$ lava flows, moderately rough relief; associated shield volcano has two nested craters (outer crater, $0.6 \mathrm{~km}$ diameter; inner crater, $0.1 \mathrm{~km}$ diameter). Contains phenocrysts of plagioclase $(5 \%, \leq 4 \mathrm{~mm})$ and olivine $(1-10 \%, \leq 7 \mathrm{~mm})$. Exposed over $24.5 \mathrm{~km}^{2}$; lava flows reach at least $9.7 \mathrm{~km}$ from vent. Overlies unit bay; underlies units bar $(130.3 \pm 5.0 \mathrm{ka}), \mathrm{bjb}$, and bsas $(115.3 \pm 7.5 \mathrm{ka}) .{ }^{40} \mathrm{Ar} /{ }^{39} \mathrm{Ar}$ ages, $362.8 \pm 12.2 \mathrm{ka}, 371.5 \pm 14.4$ $\mathrm{ka}$; eruption age, 366.4 $\pm 9.3 \mathrm{ka}$ (weighted mean age). [C2, D2]

Basalt of Al Ushayrah (middle Pleistocene) - 'A'āa and pāhoehoe basaltic lava flows of very subdued relief. Exposed over $3.7 \mathrm{~km}^{2}$; lava flows reach at least $3.5 \mathrm{~km}$ from vent. Underlies units bmuf and bri (438.9 $\pm 21.0 \mathrm{ka})[\mathrm{F} 1]$

Basalt of Usquf (middle Pleistocene) - 'A'ā and pāhoehoe basaltic lava flows, very subdued relief. Exposed over $4.5 \mathrm{~km}^{2}$; lava flows reach at least $4.8 \mathrm{~km}$ from vent. Underlies units bmuf and brum [F1] 
Hawaiite of As Sabah (middle Pleistocene) — 'A'ā and pāhoehoe hawaiite (47.3-47.8\% $\mathrm{SiO}_{2} ; 1.48$ $1.52 \% \mathrm{~K}_{2} \mathrm{O}$ ) lava flows, moderate relief; associated partly collapsed scoria cone. Contains phenocrysts of plagioclase $(1-2 \%, \leq 4 \mathrm{~mm})$ and olivine $(<1-2 \%, \leq 1 \mathrm{~mm})$. Exposed over $10.4 \mathrm{~km}^{2}$; lava flows reach at least $3.6 \mathrm{~km}$ from vent. Underlies units bsas (115.3 $\pm 7.5 \mathrm{ka})$ and $\mathrm{mmu}(219.6 \pm 4.0 \mathrm{ka})$ [D2]

mha

$\mathrm{mns}$

mnzy

msi

msr

muq

$\mathrm{mz3}$

mz6

mzy

oju

Mugearite of Al Harara (middle Pleistocene) — ' $\mathrm{A}$ ' $\mathrm{a}$ and pāhoehoe mugearite $\left(52.3 \% \mathrm{SiO}_{2} ; 2.23 \%\right.$

$\mathrm{K}_{2} \mathrm{O}$ ) lava flows, very subdued relief; associated partly eroded scoria cone. Aphyric. Exposed over only $0.4 \mathrm{~km}^{2}$; lava flows reach at least $0.9 \mathrm{~km}$ from vent. Overlies units mz6, mzy $(410.3 \pm 3.4 \mathrm{ka})$, tqa, and tz6 [E2, F2]

Mugearite northwest of Al Shathaa (middle Pleistocene) — 'A' $\bar{a}$ and pāhoehoe mugearite (50.8$51.5 \% \mathrm{SiO}_{2} ; 1.82-1.95 \% \mathrm{~K}_{2} \mathrm{O}$ ) lava flows, very subdued relief; associated heavily eroded, 1.4-kmlong, elongate scoria-cone complex. Contains plagioclase phenocrysts $(1 \%, \leq 1 \mathrm{~mm})$. Exposed over 1.4 $\mathrm{km}^{2}$; lava flows reach at least $1.2 \mathrm{~km}$ from vent. Underlies units $\mathrm{mmu}(219.6 \pm 4.0 \mathrm{ka})$ and osa [D2]

Mugearite north of As Zayinah (middle Pleistocene) — ' $\mathrm{A}$ ' $\bar{a}$ and pāhoehoe mugearite (51.3\% $\mathrm{SiO}_{2}$; $2.11 \% \mathrm{~K}_{2} \mathrm{O}$ ) lava flows, subdued relief; associated partly eroded scoria cone. Aphyric. Exposed over $0.7 \mathrm{~km}^{2}$; lava flows reach at least $2.1 \mathrm{~km}$ from vent. Part of unit, along with unit mzy $(410.3 \pm 3.4 \mathrm{ka})$, is uplifted as cryptodome. Overlies units mz6, ozy (418.8 $\pm 1.9 \mathrm{ka})$, and tz6; underlies units mzy $(410.3 \pm 3.4 \mathrm{ka})$ and tef $(88.0 \pm 1.8 \mathrm{ka}) .{ }^{40} \mathrm{Ar} /{ }^{39} \mathrm{Ar}$ age, $461.2 \pm 6.2 \mathrm{ka}$ [E2, F2]

Mugearite of Sha'ib Abu Sidrah (middle Pleistocene) - ' $A$ ' $\bar{a}$ and pāhoehoe mugearite (54.2\% $\mathrm{SiO}_{2} ; 2.59 \% \mathrm{~K}_{2} \mathrm{O}$ ) lava flows, very subdued relief. Aphyric. Exposed over only $0.1 \mathrm{~km}^{2}$. Underlies unit oz4 (430.2 $\pm 6.9 \mathrm{ka})$ [E2]

Mugearite of Sha'ib Rushayyah (middle Pleistocene) — 'A' $\bar{a}$ and pāhoehoe mugearite (52.1$52.7 \% \mathrm{SiO}_{2} ; 2.29-2.34 \% \mathrm{~K}_{2} \mathrm{O}$ ) lava flows, moderate relief; associated scoria cone. Contains olivine phenocrysts $(1 \%, \leq 1 \mathrm{~mm})$. Exposed over $1.2 \mathrm{~km}^{2}$; lava flows reach at least $1.2 \mathrm{~km}$ from vent. Overlies unit osa; underlies unit besa. ${ }^{40} \mathrm{Ar} /{ }^{39} \mathrm{Ar}$ age, $389.9 \pm 5.0 \mathrm{ka}$ [D2, E2]

Mugearite of Umm Qurah (middle Pleistocene) — 'A' $\mathrm{a}$ and pāhoehoe mugearite (51.9-54.0\% $\mathrm{SiO}_{2} ; 2.24-2.58 \% \mathrm{~K}_{2} \mathrm{O}$ ) lava flows, rough relief; associated scoria cone has spatter ramparts. Contains phenocrysts of plagioclase $(<1 \%, \leq 1 \mathrm{~mm})$ and olivine $(1-4 \%, \leq 3 \mathrm{~mm})$. Exposed over $15.7 \mathrm{~km}^{2}$; lava flows reach at least $10.4 \mathrm{~km}$ from vent. Part of unit, along with unit bd3 $(307.7 \pm 4.6 \mathrm{ka})$, is uplifted as $0.7-\mathrm{km}$-diameter cryptodome. Underlies units bd3 $(307.7 \pm 4.6$ $\mathrm{ka})$, besa, bsa $(288.8 \pm 19.6 \mathrm{ka}), \mathrm{mmu}(219.6 \pm 4.0 \mathrm{ka}), \mathrm{mz2}(195.9 \pm 1.3 \mathrm{ka})$, osa, tef $(88.0 \pm 1.8$ $\mathrm{ka})$, and tg4 $(84.3 \pm 1.6 \mathrm{ka}) .{ }^{40} \mathrm{Ar} /{ }^{39} \mathrm{Ar}$ age, $385.6 \pm 12.6 \mathrm{ka}$; excursional remanent-magnetic directions indicate that unit erupted during Levantine excursion [D2, E2]

Mugearite of Um Znabah 3 (middle Pleistocene) - 'A' $\mathrm{a}$ and pāhoehoe mugearite (49.2-49.8\% $\mathrm{SiO}_{2} ; 1.77-1.80 \% \mathrm{~K}_{2} \mathrm{O}$ ) lava flows, rough relief; well-defined pressure ridges and associated partly destroyed scoria cone. Contains phenocrysts of plagioclase $(<1 \%, \leq 3 \mathrm{~mm})$ and olivine $(<1 \%, \leq 1$ $\mathrm{mm})$. Scoria cone partly destroyed during eruption of unit tef $(88.0 \pm 1.8 \mathrm{ka})$. Exposed over $5.4 \mathrm{~km}^{2}$; lava flows reach at least $8.9 \mathrm{~km}$ from vent. Overlies units bef and brg (543.3 $\pm 5.6 \mathrm{ka})$; underlies units Oz4 (430.2 $\pm 6.9 \mathrm{ka})$, tef $(88.0 \pm 1.8 \mathrm{ka}), \operatorname{tg} 4(84.3 \pm 1.6 \mathrm{ka})$, and trg (4.2 $\pm 5.2 \mathrm{ka})$. Paleomagnetic similarities indicate that unit correlates in time with eruptions of units mz6 and tz6 [E2]

Mugearite of Um Znabah 6 (middle Pleistocene) - ' A'ā and pāhoehoe mugearite (55.4\% $\mathrm{SiO}_{2}$; $2.71 \% \mathrm{~K}_{2} \mathrm{O}$ ) lava flows, very subdued relief; associated partly eroded scoria cone. Contains phenocrysts of plagioclase $(1 \%, \leq 10 \mathrm{~mm})$ and olivine $(<1 \%, \leq 2 \mathrm{~mm})$. Exposed over only 0.4 $\mathrm{km}^{2}$; lava flows reach at least $0.6 \mathrm{~km}$ from vent. Overlies units ozy (418.8 $\left.\pm 1.9 \mathrm{ka}\right)$, tqa, and tz6; underlies units mha, mnzy (461.2 $\pm 6.2 \mathrm{ka})$, and tef $(88.0 \pm 1.8 \mathrm{ka})$. Paleomagnetic similarities indicate that unit correlates in time with eruptions of units mz3 and tz6 [E2, F2]

Mugearite of As Zayinah (middle Pleistocene) - 'A' $\bar{a}$ and pāhoehoe mugearite and hawaiite (49.3-54.0\% $\left.\mathrm{SiO}_{2} ; 1.71-2.51 \% \mathrm{~K}_{2} \mathrm{O}\right)$ lava flows, rough relief and inflated surfaces; associated scoria cone. Contains phenocrysts of plagioclase $(1 \%, \leq 10 \mathrm{~mm})$ and olivine $(1 \%, \leq 1 \mathrm{~mm})$. Exposed over $13.3 \mathrm{~km}^{2}$; lava flows reach $8.5 \mathrm{~km}$ from vent. Part of unit is uplifted as $1.4-\mathrm{km}-$ diameter cryptodome. Overlies units brg (543.3 $\pm 5.6 \mathrm{ka})$, hhil $(490.1 \pm 4.6 \mathrm{ka}), \mathrm{mnzy}(461.2 \pm 6.2$ ka), oz4 (430.2 $\pm 6.9 \mathrm{ka})$, ozy (418.8 $\pm 1.9 \mathrm{ka})$, and tz6; underlies units hmk (248.2 $\pm 8.3 \mathrm{ka})$, mha, mmk $(114.4 \pm 8.5 \mathrm{ka})$, and tef $(88.0 \pm 1.8 \mathrm{ka}) .{ }^{40} \mathrm{Ar} /{ }^{39} \mathrm{Ar}$ ages, $410.0 \pm 5.9 \mathrm{ka}, 410.5 \pm 4.1 \mathrm{ka}$; eruption age, $410.3 \pm 3.4 \mathrm{ka}$ (weighted mean age) [E2, F2]

Benmoreite of Um Junb (middle Pleistocene) - Benmoreite (58.7-59.2\% $\mathrm{SiO}_{2} ; 3.90-4.28 \%$ $\left.\mathrm{K}_{2} \mathrm{O}\right)$ lava domes and trachyte $\left(59.9-63.5 \% \mathrm{SiO}_{2} ; 4.53-5.17 \% \mathrm{~K}_{2} \mathrm{O}\right)$ pyroclastic-flow deposits. Benmoreite lava domes contain phenocrysts of plagioclase and K-rich feldspars (anorthoclase and sanidine) (together, $2-15 \%, \leq 15 \mathrm{~mm})$, fayalitic olivine $(<1 \%, \leq 2 \mathrm{~mm})$, and clinopyroxene (augite and very minor aegirine) (together, $1-2 \%, \leq 3 \mathrm{~mm}$ ); trachyte pyroclastic-flow deposits 
are aphyric. Exposed over $2.9 \mathrm{~km}^{2}$; pyroclastic-flow deposits reach at least $1.4 \mathrm{~km}$ from vent. Overlies units bd1 (717.7 $\pm 12.2 \mathrm{ka})$ and osb (535.8 $\pm 11.8 \mathrm{ka})$; underlies units bhy $(235.1 \pm 7.5$ $\mathrm{ka})$, og2 (128.2 $\pm 4.2 \mathrm{ka}), \operatorname{td} 1(17.6 \pm 1.8 \mathrm{ka})$, and $\operatorname{tg} 2(93.8 \pm 2.1 \mathrm{ka})$; younger unit bya flows around it. ${ }^{40} \mathrm{Ar} /{ }^{39} \mathrm{Ar}$ ages, $424.2 \pm 1.8 \mathrm{ka}, 435.3 \pm 5.6 \mathrm{ka}, 441.2 \pm 6.9 \mathrm{ka} ; 424.2 \pm 1.8 \mathrm{ka}$ is used for age of younger dome, whereas weighted mean age of $437.6 \pm 4.3 \mathrm{ka}$ is used for older dome [D2]

Benmoreite of Al Shathaa (middle Pleistocene) - Benmoreite and trachyte (58.9-60.5\% $\mathrm{SiO}_{2}$; $3.73-4.50 \% \mathrm{~K}_{2} \mathrm{O}$ ) block-and-ash-flow and pyroclastic-flow deposits. Sourced from $0.5-\mathrm{km}-$ diameter crater. Contains phenocrysts of plagioclase and K-rich feldspars (anorthoclase and sanidine) (together, $1-10 \%, \leq 5 \mathrm{~mm}$ ) and clinopyroxene (1-3\%, $\leq 4 \mathrm{~mm})$. Exposed over $7.5 \mathrm{~km}^{2}$; pyroclasticflow deposits reach at least $2.9 \mathrm{~km}$ from source. Compared to other pyroclastic-flow deposits, unit is mostly continuous, and its margins are not as ragged or do not have as many small, isolated outcrops. Only other pyroclastic-flow deposits nearby are from units tef $(88.0 \pm 1.8 \mathrm{ka})$ and tg4 (84.3 $\pm 1.6 \mathrm{ka})$, but this unit's juvenile clasts are petrographically and geochemically distinct. Overlies units mns, muq (385.6 $\pm 12.6 \mathrm{ka})$, and mss (621.8 $\pm 24.0 \mathrm{ka})$; underlies units bsa $(288.8 \pm 19.6 \mathrm{ka}), \mathrm{hd} 2, \mathrm{mmu}$ (219.6 $\pm 4.0 \mathrm{ka}), \mathrm{msr}(389.9 \pm 5.0 \mathrm{ka}), \mathrm{mz2}(195.9 \pm 1.3 \mathrm{ka})$, and tef $(88.0 \pm 1.8 \mathrm{ka})$ [D2, E2]

Benmoreite of Um Znabah 4 (middle Pleistocene) - Benmoreite (56.4-57.6\% $\mathrm{SiO}_{2} ; 3.36-3.57 \%$ $\mathrm{K}_{2} \mathrm{O}$ ) lava domes and flows. Contains phenocrysts of plagioclase and K-rich feldspars (anorthoclase and sanidine) (together, $<1-3 \%, \leq 20 \mathrm{~mm}$ ), fayalitic olivine $(<1-2 \%, \leq 3 \mathrm{~mm}$ ), and clinopyroxene $(<1 \%, \leq 2 \mathrm{~mm})$. Exposed over $4.9 \mathrm{~km}^{2}$; two branching lava-flow lobes, northern and southern, reach at least $5.9 \mathrm{~km}$ and at least $6.5 \mathrm{~km}$, respectively, from source. Overlies units brg (543.3 $\pm 5.6 \mathrm{ka})$, msi, mz3, and oz5; underlies units mzy (410.3 $\pm 3.4 \mathrm{ka})$, tef $(88.0 \pm 1.8 \mathrm{ka})$, and tqa. ${ }^{40} \mathrm{Ar} /{ }^{39} \mathrm{Ar}$ ages, $415.5 \pm 6.2 \mathrm{ka}, 433.4 \pm 2.9 \mathrm{ka}$; eruption age, $430.2 \pm 6.9 \mathrm{ka}$ (weighted mean age) [E2]

Benmoreite of Um Znabah 5 (middle Pleistocene)-Benmoreite (59.3\% $\mathrm{SiO}_{2} ; 4.22-4.24 \% \mathrm{~K}_{2} \mathrm{O}$ ) lava flows. Contains phenocrysts of plagioclase and K-rich feldspars (anorthoclase and sanidine) (together, $<1 \%, \leq 1 \mathrm{~mm}$ ). Exposed over only $0.4 \mathrm{~km}^{2}$; lava flows reach at least $2.7 \mathrm{~km}$ from vent. Underlies units oz4 (430.2 $\pm 6.9 \mathrm{ka})$, ozy $(418.8 \pm 1.9 \mathrm{ka})$, tef $(88.0 \pm 1.8 \mathrm{ka})$, and tqa [E2]

Benmoreite of As Zayinah (middle Pleistocene)-Benmoreite (57.9-58.9\% $\mathrm{SiO}_{2} ; 3.26-4.04 \% \mathrm{~K}_{2} \mathrm{O}$ ) lava flows. Contains phenocrysts of plagioclase and K-rich feldspars (anorthoclase and sanidine) (together, $<1 \%, \leq 4 \mathrm{~mm}$ ) and fayalitic olivine $(1 \%, \leq 2 \mathrm{~mm})$. Exposed over $1.2 \mathrm{~km}^{2}$; lava flows reach at least $2.2 \mathrm{~km}$ from vent. Overlies unit oz5; underlies units mnzy (461.2 $\pm 6.2 \mathrm{ka}), \mathrm{mz6}$, mzy $(410.3 \pm 3.4 \mathrm{ka})$, tef $(88.0 \pm 1.8 \mathrm{ka})$, and tqa. ${ }^{40} \mathrm{Ar} /{ }^{39} \mathrm{Ar}$ age, $418.8 \pm 1.9 \mathrm{ka}$; paleomagnetic similarities indicate that unit correlates in time with eruption of unit brh (411.5 $\pm 5.9 \mathrm{ka})$; excursional remanent-magnetic directions indicate unit erupted during Weinen excursion [E2, F2]

Trachyte of Al Qayf (middle Pleistocene) - Trachyte (62.7-64.2\% $\mathrm{SiO}_{2} ; 5.07-5.17 \% \mathrm{~K}_{2} \mathrm{O}$ ) pyroclastic-flow deposits. Contains abundant aphyric, moderately inflated juvenile clasts. Exposed over $1.4 \mathrm{~km}^{2}$; pyroclastic-flow deposits reach at least $2.2 \mathrm{~km}$ from source. Juvenile clasts of unit are petrographically and geochemically distinct from those of unit tef $(88.0 \pm 1.8$ $\mathrm{ka}$ ), only other nearby pyroclastic-flow deposit. Overlies units oz4 (430.2 $\pm 6.9 \mathrm{ka}), \mathrm{oz5}$, ozy $(418.8 \pm 1.9 \mathrm{ka})$, and tz6; underlies units mha, mz6, and tef $(88.0 \pm 1.8 \mathrm{ka})$ [E2]

Trachyte of Um Znabah 6 (middle Pleistocene)-Trachyte $\left(60.7-61.5 \% \mathrm{SiO}_{2} ; 4.82-4.95 \% \mathrm{~K}_{2} \mathrm{O}\right)$ lava dome. Aphyric. Exposed over only $0.6 \mathrm{~km}^{2}$. Underlies units mha, mnzy (461.2 $\left.\pm 6.2 \mathrm{ka}\right)$, mz6, mzy (410.3 $\pm 3.4 \mathrm{ka})$, tef $(88.0 \pm 1.8 \mathrm{ka})$, and tqa. Paleomagnetic similarities indicate that unit correlates in time with eruptions of units mz3 and mz6 [E2, F2]

$$
\text { Eruptive Stage } 10 \text { (460 to } 570 \mathrm{ka})
$$

bada

bai

bara
Basalt of Ad Dayyir (middle Pleistocene) - Pāhoehoe and 'a'ā basaltic lava flows, subdued relief. Exposed over $2.5 \mathrm{~km}^{2}$. Overlies unit bfa; underlies units bash, bbsh, bjr (207.3 $\left.\pm 8.4 \mathrm{ka}\right)$, bms $(59.1 \pm 5.7 \mathrm{ka})$, and bss (461.9 $\pm 4.9 \mathrm{ka})[\mathrm{D} 1]$

Basalt of Al Ihn (middle Pleistocene)—Pāhoehoe and ' $\mathrm{a}$ 'ā alkalic basalt (46.7-47.5\% $\mathrm{SiO}_{2} ; 0.78$ $\left.0.85 \% \mathrm{~K}_{2} \mathrm{O}\right)$ lava flows; associated scoria cone. Contains phenocrysts of plagioclase $(<1 \%, \leq 1$ $\mathrm{mm})$ and olivine $(1-5 \%, \leq 1 \mathrm{~mm})$. Conservative reconstruction indicates that unit is present over at least $38.3 \mathrm{~km}^{2}$; lava flows reach at least $11.7 \mathrm{~km}$ from vent. Underlies units bbd $(223.4 \pm 8.6$ ka), bis, bmu (344.7 $\pm 4.8 \mathrm{ka})$, bnu (131.2 $\pm 8.3 \mathrm{ka})$, bqr, bqu, bra, brh (411.5 $\pm 5.9 \mathrm{ka})$, and bsh $(191.5 \pm 4.2 \mathrm{ka}) .{ }^{40} \mathrm{Ar} /{ }^{39} \mathrm{Ar}$ age, $546.2 \pm 9.6 \mathrm{ka}$; paleomagnetic similarities indicate that unit correlates in time with eruption of unit brg $(543.3 \pm 5.6 \mathrm{ka})$ [A1, B1]

Basalt of Ar Ra (middle Pleistocene) — 'A' $\bar{a}$ and pāhoehoe basaltic lava flows, very subdued relief; associated scoria cone. Exposed over $1.4 \mathrm{~km}^{2}$; lava flows reach at least $1.0 \mathrm{~km}$ from vent. Overlies unit byid; underlies units bhin and bns [F2] 
bbsh Basalt below Ash Shamali (middle Pleistocene)-Pāhoehoe alkalic basalt (46.6\% $\mathrm{SiO}_{2} ; 1.03 \%$ $\mathrm{K}_{2} \mathrm{O}$ ) lava flows, subdued relief. Aphyric. Exposed over only $0.5 \mathrm{~km}^{2}$; lava flows reach at least $1.0 \mathrm{~km}$ from vent. Overlies unit bada; underlies units bash and bms (59.1 $\pm 5.7 \mathrm{ka})$ [D1]

Basalt east of Dab Al Harus (middle Pleistocene) - 'A'āa and pāhoehoe basaltic lava flows, very subdued relief. Exposed over $1.4 \mathrm{~km}^{2}$; lava flows reach at least $1.7 \mathrm{~km}$ from vent. Underlies units bjr (207.3 $\pm 8.4 \mathrm{ka})$, bmsm (552.8 $\pm 19.6 \mathrm{ka})$, and bso [D1, E1]

bef

bfa

bh82

bh83

bha

bhc

bhin

bhq

bis

bjg

bjn

bkf

bmg

bmh

Basalt of Al Efairia (middle Pleistocene) — Pāhoehoe alkalic basalt (47.5-47.7\% $\mathrm{SiO}_{2} ; 0.89-0.98 \%$ $\left.\mathrm{K}_{2} \mathrm{O}\right)$ lava flows, very subdued relief. Contains phenocrysts of plagioclase $(4-10 \%, \leq 20 \mathrm{~mm})$ and olivine $(1-2 \%, \leq 3 \mathrm{~mm})$. Exposed over $5.3 \mathrm{~km}^{2}$; lava flows reach at least $8.6 \mathrm{~km}$ from vent. Underlies units $\mathrm{mz2}(195.9 \pm 1.3 \mathrm{ka}), \mathrm{mz3}$, and tef $(88.0 \pm 1.8 \mathrm{ka})$ [D2, E2]

Basalt of Al Farash (middle Pleistocene) - Pāhoehoe tholeiitic basalt (47.56-47.6\% $\mathrm{SiO}_{2} ; 0.32 \%$ $\mathrm{K}_{2} \mathrm{O}$ ) lava flows, very subdued and rilled relief; associated shield volcano has summit crater. Contains olivine phenocrysts $(7 \%, \leq 3 \mathrm{~mm})$. Exposed over $3.0 \mathrm{~km}^{2}$; lava flows reach at least 1.1 $\mathrm{km}$ from vent. Underlies units bada, bjr (207.3 $\pm 8.4 \mathrm{ka})$, and bms (59.1 $\pm 5.7 \mathrm{ka})$. Paleomagnetic similarities indicate that unit correlates in time with eruption of unit buph $(510.8 \pm 29.4 \mathrm{ka})$ [D1]

Basalt of Hill 821 (middle Pleistocene) —Pāhoehoe and ' $\mathrm{a}$ 'ā tholeiitic basalt (46.5-46.9\% $\mathrm{SiO}_{2}$; $0.26-0.30 \% \mathrm{~K}_{2} \mathrm{O}$ ) lava flows, moderate to subdued relief; channels and levees; two associated 1.1-km-long, elongate scoria cones have five craters. Contains phenocrysts of plagioclase $(<1-4 \%, \leq 30 \mathrm{~mm})$ and olivine $(3-10 \%, \leq 10 \mathrm{~mm})$. Exposed over $19.2 \mathrm{~km}^{2}$; lava flows reach at least $6.0 \mathrm{~km}$ from vent. Overlies unit bsl; underlies units blsa $(346.9 \pm 9.9 \mathrm{ka})$, bna $(162.9 \pm 11.1$ $\mathrm{ka})$, bnof $(24.4 \pm 1.3 \mathrm{ka})$, and hma $(220.5 \pm 10.9 \mathrm{ka}) .{ }^{40} \mathrm{Ar} /{ }^{39} \mathrm{Ar}$ age, $507.4 \pm 38.3 \mathrm{ka}[\mathrm{A} 1, \mathrm{~A} 2]$

Basalt of Hill 838 (middle Pleistocene) - Pāhoehoe alkalic basalt (47.1\% $\left.\mathrm{SiO}_{2} ; 0.62 \% \mathrm{~K}_{2} \mathrm{O}\right)$ lava flows, subdued relief; associated 0.6-km-long, elongate scoria cone has two craters. Contains plagioclase phenocrysts $(2 \%, \leq 70 \mathrm{~mm})$. Exposed over only $0.9 \mathrm{~km}^{2}$; lava flows reach at least $0.9 \mathrm{~km}$ from vent. Underlies units bjab $(324.7 \pm 29.3 \mathrm{ka})$ and bqg $(215.2 \pm 6.9 \mathrm{ka}) .{ }^{40} \mathrm{Ar} /{ }^{39} \mathrm{Ar}$ age, $505.1 \pm 10.3 \mathrm{ka}$ [D1]

Basalt of Hathm (middle Pleistocene) - Pāhoehoe alkalic basalt (46.4\% $\mathrm{SiO}_{2} ; 0.68 \% \mathrm{~K}_{2} \mathrm{O}$ ) lava flows, very subdued relief. Contains olivine phenocrysts $(1-2 \%, \leq 1 \mathrm{~mm})$. Exposed over only $0.7 \mathrm{~km}^{2}$. Underlies units bis, bsu $(85.7 \pm 5.7 \mathrm{ka})$, and bur $(401.8 \pm 6.3 \mathrm{ka})$ [A1]

Basalt of Half Cone (middle Pleistocene) - Pāhoehoe basaltic lava flows, very subdued relief; associated partly collapsed scoria cone. Exposed over only $0.1 \mathrm{~km}^{2}$; lava flows reach at least $0.7 \mathrm{~km}$ from vent. Underlies unit bsk [C1]

Basalt of Al Hinu (middle Pleistocene) - Pāhoehoe basaltic lava flows, subdued relief; associated 2.4-km-long, elongate scoria-cone complex has 10 craters. Exposed over $5.9 \mathrm{~km}^{2}$; lava flows reach at least $2.8 \mathrm{~km}$ from vent. Overlies unit bara; underlies units bnh and bns [F2]

Basalt of Sha'ib Huquf (middle Pleistocene)—Pāhoehoe alkalic basalt $\left(49.1 \% \mathrm{SiO}_{2} ; 1.41 \% \mathrm{~K}_{2} \mathrm{O}\right)$ lava flows; associated partly eroded scoria cone. Contains plagioclase phenocrysts $(<1 \%, \leq 4$ $\mathrm{mm})$. Exposed over only $0.01 \mathrm{~km}^{2}$. Underlies unit buph $(510.8 \pm 29.4 \mathrm{ka})$ [E1]

Basalt of Al Iskan (middle Pleistocene) _-Pāhoehoe and 'a'ā alkalic basalt (46.4\% $\mathrm{SiO}_{2} ; 0.77$ $\left.0.87 \% \mathrm{~K}_{2} \mathrm{O}\right)$ lava flows, very subdued relief. Contains phenocrysts of plagioclase $(<1 \%, \leq 5$ $\mathrm{mm}$ ) and olivine $(2-4 \%, \leq 4 \mathrm{~mm})$. Exposed over $6.4 \mathrm{~km}^{2}$; lava flows reach at least $4.4 \mathrm{~km}$ from vent. Overlies units bai (546.2 $\pm 9.6 \mathrm{ka})$ and bha; underlies units bmu (344.7 $\pm 4.8 \mathrm{ka})$, bra, bsu $(85.7 \pm 5.7 \mathrm{ka})$, and bur $(401.8 \pm 6.3 \mathrm{ka})[\mathrm{A} 1]$

Basalt of Al Jaga (middle Pleistocene) - Pāhoehoe basaltic lava flows, very subdued relief. Exposed over only $0.3 \mathrm{~km}^{2}$. Underlies unit bsas (115.3 $\left.\pm 7.5 \mathrm{ka}\right)$ [C2]

Basalt of Al Jan (middle Pleistocene)_Pāhoehoe and 'a'ā alkalic basalt (47.8\% $\mathrm{SiO}_{2} ; 0.78 \% \mathrm{~K}_{2} \mathrm{O}$ ) lava flows, moderately subdued relief. Contains phenocrysts of plagioclase $(\leq 1 \%, \leq 8 \mathrm{~mm})$ and olivine $(1-5 \%, \leq 8 \mathrm{~mm})$. Exposed over $2.3 \mathrm{~km}^{2}$; lava flows reach at least $3.3 \mathrm{~km}$ from vent. Underlies units bd3 (307.7 $\pm 4.6 \mathrm{ka})$, tef $(88.0 \pm 1.8 \mathrm{ka})$, and tg4 (84.3 $\pm 1.6 \mathrm{ka}) .{ }^{40} \mathrm{Ar} /{ }^{39} \mathrm{Ar}$ age, $512.8 \pm 9.3 \mathrm{ka}[\mathrm{D2}$, E2]

Basalt of Al Khafaq (middle Pleistocene) - Pāhoehoe and ' $\mathrm{a}$ 'ā alkalic basalt (46.9-47.3\% $\mathrm{SiO}_{2}$; $0.66-0.81 \% \mathrm{~K}_{2} \mathrm{O}$ ) lava flows, subdued relief; associated 0.8-km-long, elongate scoria cone has five craters. Aphyric. Exposed over $25.2 \mathrm{~km}^{2}$; lava flows reach at least $9.5 \mathrm{~km}$ from vent. Underlies units bms $(59.1 \pm 5.7 \mathrm{ka})$, bsk, and han3 $(51.0 \pm 9.0 \mathrm{ka})$ [C1]

Basalt of Al Mughatiyah (middle Pleistocene) - 'A' $\mathrm{a}$ and pāhoehoe alkalic basalt (48.1\% $\mathrm{SiO}_{2}$; $1.15 \% \mathrm{~K}_{2} \mathrm{O}$ ) lava flows, moderately subdued relief; pressure ridges; associated partly collapsed scoria cone. Aphyric. Exposed over $1.9 \mathrm{~km}^{2}$; lava flows reach at least $6.5 \mathrm{~km}$ from vent. Underlies units bsk and han3 $(51.0 \pm 9.0 \mathrm{ka}) .{ }^{40} \mathrm{Ar} /{ }^{39} \mathrm{Ar}$ age, $570.0 \pm 5.9 \mathrm{ka}$ [C1]

Basalt of Al Muq'iyah (middle Pleistocene) - 'A' 'ā and minor pāhoehoe alkalic basalt (47.8\% $\mathrm{SiO}_{2}$; $0.91 \% \mathrm{~K}_{2} \mathrm{O}$ ) lava flows, moderately rough relief; associated scoria cone. Contains phenocrysts of 
plagioclase $(<1 \%, \leq 10 \mathrm{~mm})$ and olivine $(<1 \%, \leq 1 \mathrm{~mm})$. Exposed over $1.9 \mathrm{~km}^{2}$; lava flows reach at least $1.4 \mathrm{~km}$ from vent. Underlies units bml $(222.2 \pm 5.8 \mathrm{ka})$ and buph $(510.8 \pm 29.4 \mathrm{ka})$ [E1]

bmsm

bqu

brag

brg

bss

btw

buph

busm

bwhu

byid

bzi

hhil

og3

Basalt of Al Musamma (middle Pleistocene) - Pāhoehoe alkalic basalt $\left(48.1 \% \mathrm{SiO}_{2} ; 1.18 \% \mathrm{~K}_{2} \mathrm{O}\right)$ lava flows, very subdued relief. Exposed over only $0.8 \mathrm{~km}^{2}$. Overlies units bedh and bmy $(660.4 \pm 13.4 \mathrm{ka})$; underlies unit bsm. ${ }^{40} \mathrm{Ar} /{ }^{39} \mathrm{Ar}$ age, $552.8 \pm 19.6 \mathrm{ka}[\mathrm{E} 1]$

Basalt of Quba (middle Pleistocene) — Pāhoehoe and minor ' $\mathrm{a}$ 'ā tholeiitic basalt (46.7-46.8\% $\mathrm{SiO}_{2}$; $\left.0.29-0.38 \% \mathrm{~K}_{2} \mathrm{O}\right)$ lava flows, very subdued relief. Contains phenocrysts of plagioclase $(<1 \%, \leq 15$ $\mathrm{mm}$ ) and olivine $(2-4 \%, \leq 7 \mathrm{~mm})$. Conservative reconstruction indicates that unit is present over at least $13.7 \mathrm{~km}^{2}$; lava flows reach at least $8.3 \mathrm{~km}$ from vent. Overlies unit bai (546.2 $\left.\pm 9.6 \mathrm{ka}\right)$; underlies

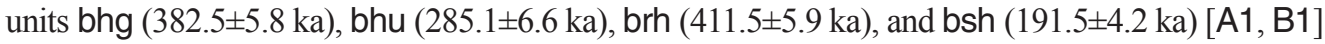

Basalt of Ar Raghibah (middle Pleistocene) - 'A' $\bar{a}$ and pāhoehoe basaltic lava flows, very subdued relief. Exposed over $3.9 \mathrm{~km}^{2}$; lava flows reach at least $4.0 \mathrm{~km}$ from vent. Underlies units bduw and bsf $(217.5 \pm 6.7 \mathrm{ka})$ [D1]

Basalt of Um Rgaibah (middle Pleistocene) - 'A' $\mathrm{a}$ and pāhoehoe tholeiitic and alkalic basalt $\left(47.2-48.4 \% \mathrm{SiO}_{2} ; 0.14-0.80 \% \mathrm{~K}_{2} \mathrm{O}\right)$ lava flows, moderately subdued relief. Contains olivine phenocrysts $(<1-2 \%, \leq 3 \mathrm{~mm})$. Exposed over $2.7 \mathrm{~km}^{2}$. Underlies units mz3, mzy (410.3 \pm 3.4 $\mathrm{ka})$, oz4 $(430.2 \pm 6.9 \mathrm{ka})$, and tef $(88.0 \pm 1.8 \mathrm{ka}) .{ }^{40} \mathrm{Ar} /{ }^{39} \mathrm{Ar}$ ages, $542.0 \pm 6.3 \mathrm{ka}, 544.3 \pm 22.0 \mathrm{ka}$, $550.0 \pm 14.9 \mathrm{ka}$; eruption age, $543.3 \pm 5.6 \mathrm{ka}$ (weighted mean age); paleomagnetic similarities indicate that unit correlates in time with eruption of unit bai $(546.2 \pm 9.6 \mathrm{ka})$ [E2]

Basalt of Sha'ib Si'ayd (middle Pleistocene) — 'A' $a \bar{a}$ and pāhoehoe alkalic basalt (47.0\% $\mathrm{SiO}_{2}$; $\left.1.03 \% \mathrm{~K}_{2} \mathrm{O}\right)$ lava flows, very subdued relief. Contains phenocrysts of plagioclase $(5-7 \%, \leq 15$ $\mathrm{mm}$ ) and olivine $(3-4 \%, \leq 10 \mathrm{~mm})$. Exposed over $3.9 \mathrm{~km}^{2}$; lava flows reach at least $1.8 \mathrm{~km}$ from vent. Overlies units bada and bwhu; underlies units bash, bda (223.0 $\pm 18.9 \mathrm{ka})$, bsm, and murr. ${ }^{40} \mathrm{Ar} /{ }^{39} \mathrm{Ar}$ age, $461.9 \pm 4.9 \mathrm{ka}[\mathrm{D} 1, \mathrm{D} 2]$

Basalt of Abu Tunaydibah West (middle Pleistocene) - 'A' $\bar{a}$ and pāhoehoe alkalic basalt (46.1\% $\mathrm{SiO}_{2} ; 0.70 \% \mathrm{~K}_{2} \mathrm{O}$ ) lava flows, very subdued relief; associated $0.7-\mathrm{km}$-long, elongate scoriacone complex. Contains phenocrysts of plagioclase $(2-3 \%, \leq 1 \mathrm{~mm})$ and olivine $(2-3 \%, \leq 1$ $\mathrm{mm}$ ). Exposed over only $0.4 \mathrm{~km}^{2}$; lava flows reach at least $0.7 \mathrm{~km}$ from vent. Underlies unit bte. ${ }^{40} \mathrm{Ar} /{ }^{39} \mathrm{Ar}$ age, $497.5 \pm 37.5 \mathrm{ka}$ [D1]

Basalt of Upper Sha'ib Huquf (middle Pleistocene)— 'A'ā and pāhoehoe alkalic basalt (47.3\% $\mathrm{SiO}_{2} ; 0.70 \% \mathrm{~K}_{2} \mathrm{O}$ ) lava flows, subdued relief; associated $0.8-\mathrm{km}$-long, elongate scoria-cone complex. Exposed over $17.0 \mathrm{~km}^{2}$; lava flows reach at least $6.9 \mathrm{~km}$ from vent. Overlies units bgh, bhq, bja (698.1 $\pm 16.0 \mathrm{ka})$, bmh, and bsw; underlies units bml (222.2 $\pm 5.8 \mathrm{ka})$, bso, and busb $(302.3 \pm 14.8 \mathrm{ka}) .{ }^{40} \mathrm{Ar} /{ }^{39} \mathrm{Ar}$ age, $510.8 \pm 29.4 \mathrm{ka}$; paleomagnetic similarities indicate that unit correlates in time with eruption of unit bfa; excursional remanent-magnetic directions indicate unit erupted during West Eifel excursion [E1, E2]

Basalt of Upper Sha'ib Murayyikh (middle Pleistocene) — 'A' $\bar{a}$ and pāhoehoe basaltic lava flows, very subdued relief; associated heavily eroded scoria cone. Exposed over only $0.2 \mathrm{~km}^{2}$; lava flows reach at least $0.3 \mathrm{~km}$ from vent. Underlies unit hd2 [D2]

Basalt west of Al Hurus (middle Pleistocene) - 'A' $\mathrm{a}$ and pāhoehoe basaltic lava flows, very subdued relief. Exposed over $3.0 \mathrm{~km}^{2}$; lava flows reach at least $6.8 \mathrm{~km}$ from vent. Underlies units bda (223.0 $\pm 18.9 \mathrm{ka})$, bjr (207.3 $\pm 8.4 \mathrm{ka})$, bsm, bss (461.9 $\pm 4.9 \mathrm{ka})$, and hd2 [D1, D2]

Basalt of Yidum (middle Pleistocene) _ 'A' $\bar{a}$ and pāhoehoe basaltic lava flows, subdued relief; associated scoria cone. Exposed over only $0.4 \mathrm{~km}^{2}$; lava flows reach at least $0.5 \mathrm{~km}$ from vent. Underlies units bara and bns [F2]

Basalt of Az Zinitah (middle Pleistocene) _ 'A' $\bar{a}$ and pāhoehoe basaltic flows, very subdued relief; associated 1.1-km-long, elongate vent zone consists of two scoria-cone complexes and four craters. Exposed over $8.5 \mathrm{~km}^{2}$; lava flows reach at least $4.0 \mathrm{~km}$ from vent. Underlies units bms $(59.1 \pm 5.7 \mathrm{ka})$, bqg $(215.2 \pm 6.9 \mathrm{ka})$, and bsy $(236.2 \pm 29.2 \mathrm{ka})[\mathrm{C} 1, \mathrm{D} 1]$

Hawaiite of Hilayyat (middle Pleistocene)-Pāhoehoe and ' $\mathrm{a}$ 'ā hawaiite (49.8\% $\mathrm{SiO}_{2} ; 1.87 \%$ $\left.\mathrm{K}_{2} \mathrm{O}\right)$ lava flows, moderate to subdued relief. Contains plagioclase phenocrysts $(<1 \%, \leq 4 \mathrm{~mm})$. Exposed over $19.6 \mathrm{~km}^{2}$; lava flows reach at least $9.7 \mathrm{~km}$ from vent. Overlies unit bgo; underlies units hmk (248.2 $\pm 8.3 \mathrm{ka}), \mathrm{mmk}(114.4 \pm 8.5 \mathrm{ka}), \mathrm{mzy}(410.3 \pm 3.4 \mathrm{ka})$, and tef $(88.0 \pm 1.8$ ka). ${ }^{40} \mathrm{Ar} /{ }^{39} \mathrm{Ar}$ age, $490.1 \pm 4.6 \mathrm{ka}[\mathrm{E} 2, \mathrm{~F} 2]$

Benmoreite of Gura 3 (middle Pleistocene)-Benmoreite (57.4\% $\left.\mathrm{SiO}_{2} ; 3.32 \% \mathrm{~K}_{2} \mathrm{O}\right)$ lava flows; exposed in crater wall of unit tg3 $(142.4 \pm 2.2 \mathrm{ka})$. Contains fayalitic olivine phenocrysts (2-3\%, $\leq 3 \mathrm{~mm})$. Underlies units bda $(223.0 \pm 18.9 \mathrm{ka}), \operatorname{tg} 2(93.8 \pm 2.1 \mathrm{ka})$, and tg3 (142.4 $\pm 2.2 \mathrm{ka})$. ${ }^{40} \mathrm{Ar} /{ }^{39} \mathrm{Ar}$ age, $558.7 \pm 4.8 \mathrm{ka}[\mathrm{D} 2]$ 
Benmoreite of As Sabah (middle Pleistocene) - 'A'ā and pāhoehoe benmoreite (55.8\% $\mathrm{SiO}_{2}$; $3.08 \% \mathrm{~K}_{2} \mathrm{O}$ ) lava flows, moderate relief; pressure ridges. Contains phenocrysts of plagioclase and K-rich feldspars (anorthoclase and sanidine) (together, $1 \%, \leq 1 \mathrm{~mm}$ ) and fayalitic olivine $(1 \%, \leq 1 \mathrm{~mm})$. Vent was destroyed by eruption of unit oju $(424.2 \pm 1.8 \mathrm{ka}, 437.6 \pm 4.3$ $\mathrm{ka}$ ). Exposed over $2.1 \mathrm{~km}^{2}$; lava flows reach at least $4.5 \mathrm{~km}$ from vent. Overlies unit bd1 $(717.7 \pm 12.2 \mathrm{ka})$; underlies units bhy $(235.1 \pm 7.5 \mathrm{ka})$, bsas (115.3 $\pm 7.5 \mathrm{ka})$, and oju (424.2 \pm 1.8 ka, $437.6 \pm 4.3 \mathrm{ka}) .{ }^{40} \mathrm{Ar} /{ }^{39} \mathrm{Ar}$ age, $535.8 \pm 11.8 \mathrm{ka}[\mathrm{D} 2]$

\section{Eruptive Stage 11 (570 to $780 \mathrm{ka}$ )}

bas

bat

bba

bd1

bg1

bja

bmy

bsd

bsl

bsw

buq

Basalt of Abu Sidrah (middle Pleistocene) — Pāhoehoe and minor 'a 'ā basaltic lava flows, subdued relief; associated scoria cone. Exposed over $5.1 \mathrm{~km}^{2}$; lava flows reach at least $2.4 \mathrm{~km}$ from vent. Overlies unit bgh; underlies units hd2 and mss (621.8 $\pm 24.0 \mathrm{ka})$ [E2]

Basalt of Atiq (middle Pleistocene) - Pāhoehoe basaltic lava flows, very subdued relief; associated scoria cone. Exposed over $1.6 \mathrm{~km}^{2}$; lava flows reach at least $1.4 \mathrm{~km}$ from vent. Underlies units bmy $(660.4 \pm 13.4 \mathrm{ka})$ and bsm [D1, D2, E1, E2]

Basalt of Al Bayadah (middle Pleistocene) - Pāhoehoe alkalic basalt (47.9\% $\mathrm{SiO}_{2} ; 0.94 \% \mathrm{~K}_{2} \mathrm{O}$ ) lava flows, subdued relief; associated scoria cone. Aphyric. Exposed over only $0.5 \mathrm{~km}^{2}$; lava flows reach at least $0.8 \mathrm{~km}$ from vent. Underlies unit oba $(242.8 \pm 2.4 \mathrm{ka}) .{ }^{40} \mathrm{Ar} /{ }^{39} \mathrm{Ar}$ age, $674.7 \pm 7.2 \mathrm{ka}$ [D2]

Basalt of Dabaa 1 (middle Pleistocene) - Pāhoehoe tholeiitic and alkalic basalt (47.0-48.5\% $\mathrm{SiO}_{2}$; $0.36-1.01 \% \mathrm{~K}_{2} \mathrm{O}$ ) lava flows, subdued relief; associated scoria cone. Parts of lava flows are uplifted by unit td $1(17.6 \pm 1.8 \mathrm{ka})$. Contains phenocrysts of plagioclase $(1 \%, \leq 20 \mathrm{~mm})$ and olivine $(3-10 \%, \leq 10 \mathrm{~mm})$. Exposed over only $0.9 \mathrm{~km}^{2}$; lava flows reach at least $1.9 \mathrm{~km}$ from vent. Overlies unit bg1; underlies units og2 (128.2 $\pm 4.2 \mathrm{ka})$, oju (424.2 $\pm 1.8 \mathrm{ka}, 437.6 \pm 4.3 \mathrm{ka})$, osb (535.8 $\pm 11.8 \mathrm{ka})$, td1 $(17.6 \pm 1.8 \mathrm{ka})$, and tg2 $(93.8 \pm 2.1 \mathrm{ka}) .{ }^{40} \mathrm{Ar} /{ }^{39} \mathrm{Ar}$ age, $717.7 \pm 12.2 \mathrm{ka}$ [D2]

Basalt of Gura 1 (middle Pleistocene) —Alkalic basalt (47.5-48.1\% $\mathrm{SiO}_{2} ; 0.93-1.15 \% \mathrm{~K}_{2} \mathrm{O}$ ). Consists of scoria cone, uplifted lava flows along margin of lava dome and crater complex of unit tg2 $(93.8 \pm 2.1 \mathrm{ka})$, and flow uplifted in margins of a maar crater. Contains phenocrysts of plagioclase $(1 \%, \leq 8 \mathrm{~mm})$ and olivine $(1 \%, \leq 4 \mathrm{~mm})$. Exposed over only $0.5 \mathrm{~km}^{2}$; lava flows

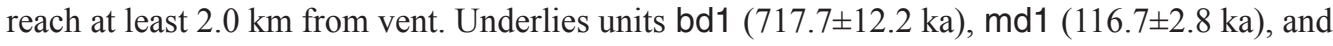
$\operatorname{tg} 2(93.8 \pm 2.1 \mathrm{ka})[\mathrm{D} 2]$

Basalt of Al Jar'ah (middle Pleistocene) —Pāhoehoe and 'a'ā alkalic basalt (47.9-48.6\% $\mathrm{SiO}_{2}$; $0.88-0.94 \% \mathrm{~K}_{2} \mathrm{O}$ ) lava flows, moderate relief; associated 1.1-km-long, elongate scoria-cone complex has four craters. Contains olivine phenocrysts ( $1 \%, \leq 3 \mathrm{~mm})$. Exposed over $5.9 \mathrm{~km}^{2}$; lava flows reach at least $2.8 \mathrm{~km}$ from vent. Underlies units bml (222.2 $\pm 5.8 \mathrm{ka})$, bso, and buph $(510.8 \pm 29.4 \mathrm{ka}) .{ }^{40} \mathrm{Ar} /{ }^{39} \mathrm{Ar}$ age, $698.1 \pm 16.0 \mathrm{ka}$ [E1]

Basalt of Al Matyan (middle Pleistocene) - 'A'ā and pāhoehoe alkalic basalt (47.3-48.0\% $\mathrm{SiO}_{2}$; $\left.0.81-0.89 \% \mathrm{~K}_{2} \mathrm{O}\right)$ lava flows, very subdued relief. Contains phenocrysts of plagioclase $(<1-2 \%$, $\leq 10 \mathrm{~mm}$ ) and olivine $(1-5 \%, \leq 2 \mathrm{~mm})$. Exposed over $8.0 \mathrm{~km}^{2}$; lava flows reach at least $8.3 \mathrm{~km}$ from vent. Overlies units bat, bgh, and bsw; underlies units bhm, bmsm (552.8 $19.6 \mathrm{ka})$, bsm, bso, and hd2. ${ }^{40} \mathrm{Ar} /{ }^{39} \mathrm{Ar}$ age, $660.4 \pm 13.4 \mathrm{ka}[\mathrm{E} 1, \mathrm{E} 2]$

Basalt of Sha'ib Ad Dirwah (middle Pleistocene) - ' $A$ 'ā and pāhoehoe alkalic basalt (46.9-47.1\% $\mathrm{SiO}_{2} ; 0.74-0.76 \% \mathrm{~K}_{2} \mathrm{O}$ ) lava flows, very subdued relief; associated scoria cone. Contains phenocrysts of plagioclase $(1 \%, \leq 30 \mathrm{~mm})$ and olivine $(1-2 \%, \leq 3 \mathrm{~mm})$. Exposed over $6.7 \mathrm{~km}^{2}$; lava flows reach at least $5.9 \mathrm{~km}$ from vent. Overlies units bgh, bush, and mss (621.8 $\pm 24.0 \mathrm{ka})$; underlies units buj, buq, mz2 (195.9 $\pm 1.3 \mathrm{ka})$, and tg4 $(84.3 \pm 1.6 \mathrm{ka}) .{ }^{40} \mathrm{Ar}{ }^{\beta 9} \mathrm{Ar}$ age, $584.5 \pm 10.4 \mathrm{ka}$; excursional remanent-magnetic directions indicate that unit erupted during Calabrian Ridge 3 excursion [E2]

Basalt of Sha'ib Luwa (middle Pleistocene) - 'A' ${ }^{\prime} \bar{a}$ and pāhoehoe tholeiitic basalt (46.6-47.9\% $\left.\mathrm{SiO}_{2} ; 0.26-0.36 \% \mathrm{~K}_{2} \mathrm{O}\right)$ lava flows, very subdued relief. Contains phenocrysts of plagioclase $(<1 \%, \leq 15 \mathrm{~mm})$ and olivine $(<1-10 \%, \leq 5 \mathrm{~mm})$. Exposed over $9.6 \mathrm{~km}^{2}$; lava flows reach at least $5.5 \mathrm{~km}$ from vent. Overlies unit buqa $(1,069.6 \pm 19.3 \mathrm{ka})$; underlies units bh82 $(507.4 \pm 38.3 \mathrm{ka})$,

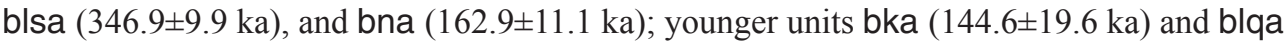
$(196.9 \pm 10.3 \mathrm{ka})$ flowed around margin of this unit [A1, A2]

Basalt of Umm Suwasi (middle Pleistocene) - 'A'ā and pāhoehoe basaltic lava flows, very subdued relief; associated scoria cone. Exposed over $3.5 \mathrm{~km}^{2}$; lava flows reach at least $3.2 \mathrm{~km}$ from vent. Overlies unit bgh; underlies units bmy (660.4 $\pm 13.4 \mathrm{ka})$ and buph (510.8 $\pm 29.4 \mathrm{ka})$ [E1, E2]

Basalt of Umm Qubayr (middle Pleistocene) - 'A $\mathrm{A}^{\prime} \bar{a}$ and pāhoehoe tholeiitic basalt (46.9\% $\mathrm{SiO}_{2}$; $0.44 \% \mathrm{~K}_{2} \mathrm{O}$ ) lava flows, subdued relief; associated scoria cone. Aphyric. Exposed over $1.2 \mathrm{~km}^{2}$;

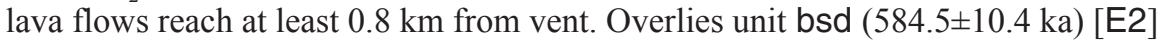


Basalt of Al Ushu'a (middle Pleistocene) — 'A'āa and pāhoehoe basaltic lava flows, very subdued relief; associated heavily eroded scoria-cone complex. Exposed over only $0.6 \mathrm{~km}^{2}$; lava flows

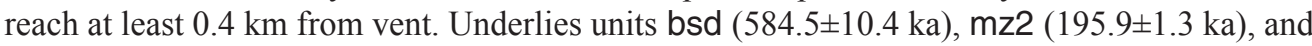
$\operatorname{tg} 4(84.3 \pm 1.6 \mathrm{ka})$ [E2]

mss

bg3

bgh

bgo

bh89

bqa

buqa

Qbra

Qbhk

Qbjs

Basalt 0

$\% \mathrm{SiO}_{2} ; 2.20-2.29 \% \mathrm{~K}_{2} \mathrm{O}$ ) lava flows, very subdued relief. Aphyric. Exposed over $5.4 \mathrm{~km}^{2}$ lava flows reach at least $4.7 \mathrm{~km}$ from vent. Overlies unit bas; underlies units bsd $(584.5 \pm 10.4$ ka), $\mathrm{mz2}(195.9 \pm 1.3 \mathrm{ka})$, and osa. ${ }^{40} \mathrm{Ar} /{ }^{39} \mathrm{Ar}$ age, $621.8 \pm 24.0 \mathrm{ka}[\mathrm{D} 2$, E2]

\section{Eruptive Stage 12 (780 to $1,200 \mathrm{ka})$}

Basalt of Gura 3 (early Pleistocene) - Alkalic basalt (48.2\% $\left.\mathrm{SiO}_{2} ; 1.16 \% \mathrm{~K}_{2} \mathrm{O}\right)$ lava flows. Contains olivine phenocrysts $(1 \%, \leq 1 \mathrm{~mm})$. Present in crater of unit tg3 $(142.4 \pm 2.2 \mathrm{ka})$. Exposed over only $0.03 \mathrm{~km}^{2}$. Underlies unit tg2 $(93.8 \pm 2.1 \mathrm{ka}) .{ }^{40} \mathrm{Ar} /{ }^{39} \mathrm{Ar}$ age, $1,112.1 \pm 17.6 \mathrm{ka}$ [D2]

Basalt of Ghadwar (early Pleistocene) - Pāhoehoe tholeiitic basalt (47.6-48.2\% $\mathrm{SiO}_{2} ; 0.30-0.43 \%$ $\mathrm{K}_{2} \mathrm{O}$ ) lava flows, heavily rilled relief; associated shield volcano has $0.8-\mathrm{km}$-long, elongate crater. Contains phenocrysts of plagioclase $(3-15 \%, \leq 3 \mathrm{~mm})$ and olivine $(3-5 \%, \leq 3 \mathrm{~mm})$. Exposed over $21.7 \mathrm{~km}^{2}$; lava flows reach at least $5.1 \mathrm{~km}$ north, and $7.1 \mathrm{~km}$ south, of vent. Underlies units bas, bhm, bml (222.2 $\pm 5.8 \mathrm{ka})$, bmy (660.4 $\pm 13.4 \mathrm{ka})$, bsd $(584.5 \pm 10.4 \mathrm{ka})$, bsw, buph (510.8 $\pm 29.4 \mathrm{ka})$, and busb $(302.3 \pm 14.8 \mathrm{ka})$ [E1, E2, F1, F2]

Basalt of Gorab (early Pleistocene) - Pāhoehoe and 'a'ā alkalic basalt (47.0\% $\left.\mathrm{SiO}_{2} ; 0.82 \% \mathrm{~K}_{2} \mathrm{O}\right)$ lava flows, subdued relief. Contains phenocrysts of plagioclase $(2 \%, \leq 15 \mathrm{~mm})$ and olivine $(3-4 \%, \leq 7 \mathrm{~mm})$. Exposed over $15.8 \mathrm{~km}^{2}$; lava flows reach at least $7.5 \mathrm{~km}$ from vent. Underlies unit hhil $(490.1 \pm 4.6 \mathrm{ka})$ [E2]

Basalt of Hill 892 (early Pleistocene) - Pāhoehoe and minor ' $\mathrm{a}$ 'ā alkalic basalt (47.8\% $\mathrm{SiO}_{2} ; 0.88 \%$ $\mathrm{K}_{2} \mathrm{O}$ ) lava flows, very subdued relief; associated shield volcano has $0.2-\mathrm{km}$-diameter central crater. Aphyric. Exposed over $1.9 \mathrm{~km}^{2}$; lava flows reach at least $1.5 \mathrm{~km}$ from vent. Underlies units bsb and han3 $(51.0 \pm 9.0 \mathrm{ka}) .{ }^{40} \mathrm{Ar} /{ }^{39} \mathrm{Ar}$ age, $1,014.0 \pm 14.0 \mathrm{ka}$; excursional remanentmagnetic directions indicate unit erupted during termination of Jaramillo Subchron (Gradstein and others, 2012) [B1, C1]

Basalt of Al Qafif (early Pleistocene) —'A ' ‘ā and pāhoehoe tholeiitic basalt (47.4\% $\mathrm{SiO}_{2} ; 0.43 \%$ $\left.\mathrm{K}_{2} \mathrm{O}\right)$ lava flows, very subdued relief. Aphyric. Only very small part $\left(1.7 \mathrm{~km}^{2}\right)$ of unit is present in map area. Underlies unit bme [F2]

Basalt of Upper Qa Al Aqul (early Pleistocene) - ' $\mathrm{A}$ 'āa and pāhoehoe alkalic basalt (47.5\% $\mathrm{SiO}_{2}$; $\left.0.90 \% \mathrm{~K}_{2} \mathrm{O}\right)$ lava flows, subdued relief. Contains phenocrysts of plagioclase $(<1 \%, \leq 1 \mathrm{~mm})$ and olivine $(3 \%, \leq 10 \mathrm{~mm})$. Exposed over $6.3 \mathrm{~km}^{2}$; lava flows reach at least $4.4 \mathrm{~km}$ from vent. Underlies units bla (1256 C.E.), blsa (346.9 $\pm 9.9 \mathrm{ka})$, and bsl; younger unit blqa (196.9 \pm 10.3 ka) flowed around this unit. ${ }^{40} \mathrm{Ar} /{ }^{39} \mathrm{Ar}$ ages, $961.0 \pm 45.0 \mathrm{ka}, 1,073.0 \pm 8.0 \mathrm{ka}$; eruption age, $1,069.6 \pm 19.3 \mathrm{ka}$ (weighted mean age) [A1]

\section{VOLCANIC ROCKS OF HARRAT KURAMA}

Basalt of Harrat Kurama (early Pleistocene) - Undifferentiated basaltic lava flows from Harrat Kurama, which is situated northeast of northern Harrat Rahat. Some lava flows have made their way through rugged Precambrian terrane and are now proximal to younger northern Harrat Rahat lava flows [A2]

Basalt of Jabal Umm Suhaylah (early Pleistocene) - 'A'ā and pāhoehoe alkalic basalt (46.6-46.9\% $\mathrm{SiO}_{2} ; 1.10-1.11 \% \mathrm{~K}_{2} \mathrm{O}$ ) lava flows from Harrat Kurama, very subdued relief. Contains olivine phenocrysts $(1 \%, \leq 2 \mathrm{~mm})$. Overlies Precambrian rocks. Appears to have inverted topography with younger unit Qbra $(2,140.0 \pm 26.0 \mathrm{ka})$ lava flows, which are stratigraphically lower [A1]

$47.3 \% \mathrm{SiO}_{2} ; 0.84-0.88 \% \mathrm{~K}_{2} \mathrm{O}$ ) lava flows from Harrat Kurama, very subdued relief. Contains olivine phenocrysts $(5-10 \%, \leq 2 \mathrm{~mm}$ ). Overlies and surrounds Precambrian rocks; underlies unit bla (1256 C.E.). Appears to have inverted topography with older unit Qbjs, which is stratigraphically higher. Several normal faults offset these lava flows by 10 to $20 \mathrm{~m} .{ }^{40} \mathrm{Ar} /{ }^{39} \mathrm{Ar}$ age, $2,140.0 \pm 26.0 \mathrm{ka}$ [A1]

\section{TERTIARY VOLCANIC ROCKS}

Tbja

Basalt of Jabal Ayr (Miocene) - Alkalic basalt (45.8\% $\left.\mathrm{SiO}_{2} ; 1.28 \% \mathrm{~K}_{2} \mathrm{O}\right)$ lava flows. Very flat topography; covers top of hill that consists of Precambrian rocks. Presumed to have vented 
from north of northern Harrat Rahat. Contains phenocrysts of plagioclase $(10 \%, \leq 3 \mathrm{~mm})$ and olivine $(1 \%, \leq 3 \mathrm{~mm}) .{ }^{40} \mathrm{Ar} /{ }^{39} \mathrm{Ar}$ age, $13,562.0 \pm 30.2 \mathrm{ka}[\mathrm{B} 1]$

Basalt of Jabal Jammah (Miocene) - Alkalic basalt, basanite, and hawaiite (43.8-45.0\% $\mathrm{SiO}_{2}$; $1.57-1.97 \% \mathrm{~K}_{2} \mathrm{O}$ ) lava flows. Very flat topography; covers tops of six hills that consist of Precambrian rocks. Presumed to have vented from north of northern Harrat Rahat. Contains phenocrysts of plagioclase $(1 \%, \leq 2 \mathrm{~mm})$, olivine $(1-3 \%, \leq 6 \mathrm{~mm})$, and clinopyroxene $(<1 \%, \leq 5 \mathrm{~mm})$ [A1, B1]

\section{PRECAMBRIAN ROCKS}

p€

Precambrian rocks (Precambrian) - Undifferentiated metamorphosed sedimentary rocks sutured together with intrusive and extrusive igneous rocks from island-arc and back-arc terranes. Isotopic ages, lithologies, and geologic histories are summarized in Pellaton (1981), Camp (1984), Stoeser and Camp (1985), Johnson (2006), and Stern and Johnson (2010) [A1, A2, B1, B2, C1, C2, D1, D2, E1, E2, F1]

\section{References Cited}

Al-Mishwat, A.T., and Nasir, S.J., 2004, Composition of the lower crust of the Arabian Plate-A xenolith perspective: Lithos, v. 72, nos. 1-2, p. 45-72, doi:10.1016/j.lithos. 2003.08.003.

Al-Samhoody, N.A.A., 1486 [reprinted, 1955, by M.M.A. Hamid], Wafa Al-Wafa Bi'Akhbar Dar Al-Mustafa: Beirut, Lebanon, Dar Al-Ahya Al-Sarawat Al-Gharbi Publishing, 776 p.

Almond, D.C., 1986, The relation of Mesozoic-Cainozoic volcanism to tectonics in the Afro-Arabian dome: Journal of Volcanology and Geothermal Research, v. 28, no. 3, p. 225-246, doi:10.1016/0377-0273(86)90024-7.

Ambraseys, N.N., Melville, C.P., and Adams, R.D., 2005, The seismicity of Egypt, Arabia and the Red Sea-A historical review: Cambridge, U.K., Cambridge University Press, 204 p.

Bahroudi, A., and Talbot, C.J., 2004, The configuration of the basement beneath the Zagros basin: Journal of Petroleum Geology, v. 26, no. 3, p. 257-282, doi:10.1111/j.1747-5457. 2003.tb00030.x.

Bellahsen, N., Faccenna, C., Funiciello, F., Daniel, J.M., and Jolivet, L., 2003, Why did Arabia separate from Africa? Insights from 3-D laboratory experiments: Earth and Planetary Science Letters, v. 216, no. 3, p. 365-381, doi:10.1016/S0012-821X(03)00516-8.

Bosworth, W., Huchon, P., and McClay, K., 2005, The Red Sea and Gulf of Aden basins: Journal of African Earth Sciences, v. 43, nos. 1-3, p. 334-378, doi:10.1016/j.jafrearsci.2005.07.020.

Camp, V.E., 1984, Island arcs and their role in the evolution of the western Arabian Shield: Geological Society of America Bulletin, v. 95, no. 8, p. 913-921, doi:10.1130/00167606(1984)95<913:IAATRI >2.0.CO;2.

Camp, V.E., 1986, Geologic map of the Umm al Birak quadrangle, sheet 23D, Kingdom of Saudi Arabia: Saudi Arabian Deputy Ministry for Mineral Resources Geoscience Map GM-87, scale 1:250,000, 40 p.

Camp, V.E., Hooper, P.R., Roobol, M.J., and White, D.L., 1987, The Madinah eruption, Saudi Arabia-Magma mixing and simultaneous extrusion of three basaltic chemical types: Bulletin of Volcanology, v. 49, no. 2, p. 498-508, doi:10.1007/BF01245475.
Camp, V.E., and Roobol, M.J., 1989, The Arabian continental alkali basalt province - Part I. Evolution of Harrat Rahat, Kingdom of Saudi Arabia: Geological Society of America Bulletin, v. 101, no. 1, p. 71-95, doi:10.1130/00167606(1989)101<0071:TACABP>2.3.CO;2.

Camp, V.E., and Roobol, M.J., 1991, Geologic map of the Cenozoic lava field of Harrat Rahat, Kingdom of Saudi Arabia: Saudi Arabian Deputy Ministry for Mineral Resources Geoscience Map GM-123, scale 1:250,000, 37 p.

Camp, V.E., and Roobol, M.J., 1992, Upwelling asthenosphere beneath western Arabia and its regional implications: Journal of Geophysical Research, v. 97, no. B11, p. 15,25515,271, doi:10.1029/92JB00943.

Camp, V.E., Roobol, M.J., and Hooper, P.R., 1991, The Arabian continental alkali basalt province-Part II. Evolution of Harrats Khaybar, Ithnayn, and Kura, Kingdom of Saudi Arabia: Geological Society of America Bulletin, v. 103, no. 3, p. 363-391, doi:10.1130/00167606(1991)103<0363:TACABP>2.3.CO;2.

Camp, V.E., Roobol, M.J., and Hooper, P.R., 1992, The Arabian continental alkali basalt province - Part III. Evolution of Harrat Kishb, Kingdom of Saudi Arabia: Geological Society of America Bulletin, v. 104, no. 4, p. 379-396, doi:10.1130/00167606(1992) $104<0379$ :TACABP>2.3.CO;2.

Clark, M.D., 1981, Geologic map of the Al Hamra quadrangle, sheet 23C, Kingdom of Saudi Arabia: Saudi Arabian Deputy Ministry for Mineral Resources Geoscience Map GM-49, scale 1:250,000, $28 \mathrm{p}$.

Coleman, R.G., Gregory, R.T., and Brown, G.F., 1983, Cenozoic volcanic rocks of Saudi Arabia: U.S. Geological Survey Open-File Report 83-788, 82 p.

Crassard, R., Petraglia, M.D., Drake, N.A., Breeze, P., Gratuze, B., Alsharkh, A., Arbach, M., Groucutt, H.S., Khalii, L., Michelsen, N., Robin, C.J., and Schiettecatte, J., 2013, Middle Palaeolithic and Neolithic occupations around Mundafan palaeolake, Saudi Arabia-Implications for climate change and human dispersals: Plos One, v. 8, no. 7, e69665, doi:10.1371/journal.pone.0069665.

Cox, K.G., Bell, J.D., and Pankhurst, R.J., 1979, The interpretation of igneous rocks: London, U.K., George Allen and Unwin, 450 p., doi:10.1007/978-94-017-3373-1. 
Dietterich, H.R., Downs, D.T., Stelten, M.E., and Zahran, H., 2018, Reconstructing lava flow emplacement histories with rheological and morphological analyses-The Harrat Rahat volcanic field, Kingdom of Saudi Arabia: Bulletin of Volcanology, v. 80, no. 85, doi:10.1007/s00445-018-1259-4.

Downs, D.T., 2019, Major- and trace-element chemical analyses of rocks from the northern Harrat Rahat volcanic field and surrounding area, Kingdom of Saudi Arabia: U.S. Geological Survey data release, doi:10.5066/P91HL91C.

Downs, D.T., Stelten, M.E., Champion, D.E., Dietterich, H.R., Nawab, Z., Zahran, H., Hassan, K., and Shawali, J., 2018, Volcanic history of the northernmost part of the Harrat Rahat volcanic field, Saudi Arabia: Geosphere, v. 14, no. 3, p. 1253-1282, doi:10.1130/GES01625.1.

Duncan, R.A., and Al-Amri, A.M., 2013, Timing and composition of volcanic activity at Harrat Lunayyir, western Saudi Arabia: Journal of Volcanology and Geothermal Research, v. 260, p. 103-116, doi:10.1016/j.jvolgeores.2013.05.006.

Duncan, R.A., Kent, A.J.R., Thornber, C.R., Schlieder, T.D., and Al-Amri, A.M., 2016, Timing and composition of continental volcanism at Harrat Hutaymah, western Saudi Arabia: Journal of Volcanology and Geothermal Research, v. 313, p. 1-14, doi:10.1016/j.jvolgeores.2016.01.010.

Esri, 2015, World countries: Esri database, accessed April 24, 2015, at https://www.arcgis.com/home/item.html?id=ac8067 0eb213440ea5899bbf92a04998\#overview.

Gill, J.B., 1981, Orogenic andesites and plate tectonics: Berlin, Springer-Verlag, $390 \mathrm{p}$.

Gradstein, F.M., Ogg, J.G., Schmitz, M.D., and Ogg, G.M., 2012, The geologic time scale 2012: Boston, Mass., Elsevier, 1,176p.

Irvine, T.N., and Baragar, W.R.A., 1971, A guide to the chemical classification of the common volcanic rocks: Canadian Journal of Earth Sciences, v. 8, no. 5, p. 523-548, doi:10.1139/e71-055.

Johnson, P.R., 2006, Geologic map of the Arabian Shield: Saudi Geological Survey Open-File Report SGS-OF-2005-15, scale $1: 2,000,000$.

Kaiser, K., Kempf, E.K., Leroi-Gourhan, A., and Schütt, H., 1973, Quartärstratigraphische Untersuchungen aus dem DamaskusBecken und seiner Umgebung: Zeitschrift für Geomorphologie Neue Folge, v. 17, p. 263-353.

Kaviani, A., Paul, A., Bourova, E., Hatzfeld, D., Pedersen, H., and Mokhtari, M., 2007, A strong seismic velocity contrast in the shallow mantle across the Zagros collision zone (Iran): Geophysical Journal International, v. 171, no. 1, p. 399-410, doi:10.1111/j.1365-246X.2007.03535.x.

Kawabata, E., Cronin, S.J., Bebbington, M.S., Moufti, M.R., El-Masry, N., and Wang, T., 2015, Identifying multiple eruption phases from a compound blanket-An example of the AD1256 Al-Madinah eruption, Saudi Arabia: Bulletin of Volcanology, v. 77, no. 6, doi:10.1007/s00445-014-0890-y.

Kemp, J., Gros, Y., and Prian, J.P., 1982, Geologic map of the Mahd adh Dhahab quadrangle, sheet 23E, Kingdom of Saudi Arabia: Saudi Arabian Deputy Ministry for Mineral Resources Geoscience Map GM-64, scale 1:250,000, 39 p.

Kereszturi, G., Németh, K., Moufti, M.R., Cappello, A., Murcia, H., Ganci, G., Del Negro, C., Procter, J., and Zahran, H.M.A., 2016, Emplacement conditions of the 1256 AD Al-Madinah lava flow field in Harrat Rahat, Kingdom of Saudi ArabiaInsights from surface morphology and lava flow simulations: Journal of Volcanology and Geothermal Research, v. 309, p. 14-30, doi:10.1016/j.jvolgeores.2015.11.002.

Konrad, K., Graham, D.W., Thornber, C.R., Duncan, R.A., Kent, A.J.R., and Al-Amri, A.M., 2016, Asthenosphere-lithosphere interactions in western Saudi Arabia-Inferences from ${ }^{3} \mathrm{He} /{ }^{4} \mathrm{He}$ in xenoliths and lava flows from Harrat Hutaymah: Lithos, v. 248-251, p. 339-352, doi:10.1016/j.lithos.2016.01.031.

Kuo, L., and Essene, E.J., 1986, Petrology of spinel harzburgite xenoliths from the Kishb Plateau, Saudi Arabia:

Contributions to Mineralogy and Petrology, v. 93, no. 3, p. 335-346, doi:10.1007/BF00389392.

Lal, D., 1991, Cosmic ray labeling of erosion surfaces - In situ nuclide production rates and erosions models: Earth and Planetary Science Letters, v. 104, nos. 2-4, p. 424-439, doi:10.1016/0012-821X(91)90220-C.

Lee, J.-Y., Marti, K., Severinghaus, J.P., Kawamura, K., Yoo, H.-S., Lee, J.B., and Kim, J.S., 2006, A redetermination of the isotopic abundances of atmospheric Ar: Geochimica et Cosmochimica Acta, v. 70, no. 17, p. 4507-4512, doi:10.1016/j.gca.2006.06.1563.

Marrero, S.M., Phillips, F.M., Borchers, B., Lifton, N., Aumer, R., and Balco, G., 2016, Cosmogenic nuclide systematics and the CRONUScalc program: Quaternary Geochronology, v. 31, p. 160-187, doi:10.1016/j.quageo.2015.09.005.

McClure, H.A., 1978, Ar Rub’ Al Khali, in Al-Sayari, S.S., and Zotl, J.G., eds., Quaternary period in Saudi Arabia: New York, Springer-Verlag, p. 252-263, doi:10.1007/978-37091-8494-3_11.

McGuire, A.V., and Bohannon, R.G., 1989, Timing of mantle upwelling - Evidence for a passive origin for Red Sea rifting: Journal of Geophysical Research, v. 94, no. B2, p. 1677-1682, doi:10.1029/JB094iB02p01677.

Mellors, R.J., Camp, V.E., Vernon, F.L., Al-Amri, A.M.S., and Ghalib, A., 1999, Regional waveform propagation in the Arabian Peninsula: Journal of Geophysical Research, v. 104, no. B9, p. 20,221-20,235, doi:10.1029/1999JB900187.

Mohsen, A., Hofstetter, R., Bock, G., Kind, R., Weber, M., Wylegalla, K., Rümpker, G., and DESERT Group, 2005, A receiver function study across the Dead Sea Transform: Geophysical Journal International, v. 160, no. 3, p. 948-960, doi:10.1111/j.1365-246X.2005.02534.x.

Mooney, W.D., Gettings, M.E., Blank, H.R., and Healy, J.H., 1985, Saudi Arabian seismic-refraction profile-A traveltime interpretation of crustal and upper mantle structure: Tectonophysics, v. 111, nos. 3-4, p. 173-246, doi:10.1016/0040-1951(85)90287-2.

Moore, T.A., and Al-Rehaili, M.H., 1989, Geologic map of the Makkah quadrangle, sheet 21D, Kingdom of Saudi Arabia: Saudi Arabian Deputy Ministry for Mineral Resources Geoscience Map GM-107, scale 1:250,000, 62 p.

Moufti, M.R.H., 1985, The geology of Harrat Al Madinah volcanic field Harrat Rahat, Saudi Arabia: Lancaster, U.K., University of Lancaster, Ph.D. dissertation, 407 p.

Moufti, M.R., Moghazi, A.M., and Ali, K.A., 2012, Geochemistry and $\mathrm{Sr}-\mathrm{Nd}-\mathrm{Pb}$ isotopic compositions of the Harrat Al-Madinah 
Volcanic Field, Saudi Arabia: Gondwana Research, v. 21, nos 2-3, p. 670-689, doi:10.1016/j.gr.2011.06.003.

Moufti, M.R., Moghazi, A.M., and Ali, K.A., 2013, ${ }^{40} \mathrm{Ar} /{ }^{39} \mathrm{Ar}$ geochronology of the Neogene-Quaternary Harrat Al-Madinah intercontinental volcanic field, Saudi ArabiaImplications for duration and migration of volcanic activity: Journal of Asian Earth Sciences, v. 62, p. 253268, doi:10.1016/j.gr.2011.06.003.

Murcia, H., Lindsay, J.M., Németh, K., Smith, I.E.M., Cronin, S.J., Moufti, M.R.H., El-Masry, N.N., and Niedermann, S., 2017, Geology and geochemistry of Late Quaternary volcanism in northern Harrat Rahat, Kingdom of Saudi ArabiaImplications for eruption dynamics, regional stratigraphy and magma evolution, in Németh, K., Carrasco-Núñez, G., Aranda-Gómez, J.J., and Smith, I.E.M., eds., Monogenetic volcanism: Geological Society of London Special Publications, v. 446, p. 173-204, doi:10.1144/SP446.2.

Murcia, H., Németh, K., El-Masry, N.N., Lindsay, J.M., Moufti, M.R.H., Wameyo, P., Cronin, S.J., Smith, I.E.M., and Kereszturi, G., 2015, The Al-Du'aythah volcanic cones, Al-Madinah City-Implications for volcanic hazards in northern Harrat Rahat, Kingdom of Saudi Arabia: Bulletin of Volcanology, v. 77, 19 p., doi:10.1007/s00445-015-0936-9.

Nasir, S., and Safarjalani, A., 2000, Lithospheric petrology beneath the northern part of the Arabian Plate in Syria - Evidence from xenoliths in alkali basalts: Journal of African Earth Sciences, v. 30, no. 1, p. 149-168, doi:10.1016/S0899-5362(00)00013-0.

Oda, H., 2005, Recurrent geomagnetic excursions-A review for the Brunhes normal polarity chron: Journal of Geography, v. 114, no. 2, p. 174-193, doi:10.5026/jgeography.114.2_174.

Pellaton, C., 1981, Geologic map of the Al Madinah quadrangle, sheet 24D, Kingdom of Saudi Arabia: Saudi Arabian Deputy Ministry for Mineral Resources Geoscience Map GM-52, scale 1:250,000, $19 \mathrm{p}$.

Ramsay, C.R., 1986, Geologic map of the Rabigh quadrangle, sheet 22D, Kingdom of Saudi Arabia: Saudi Arabian Deputy Ministry for Mineral Resources Geoscience Map GM-84, scale 1:250,000, 49 p.

Runge, M.G., Bebbington, M.S., Cronin, S.J., Lindsay, J.M., Kenedi, C.L., and Moufti, M.R.H., 2014, Vents to eventsDetermining an eruption event record from volcanic vent structures for the Harrat Rahat, Saudi Arabia: Bulletin of Volcanology, v. 76, no. 3, 16 p., doi:10.1007/s00445-0140804-z.

Sahl, M., and Smith, J.W., 1986, Geologic map of the Al Muwayh quadrangle, sheet 22E, Kingdom of Saudi Arabia: Saudi Arabian Deputy Ministry for Mineral Resources Geoscience Map GM-88C, scale 1:250,000, 78 p.
Siebert, L., Simkin, T., and Kimberly, P., 2010, Volcanoes of the world ( $3 \mathrm{~d}$ ed.): Berkeley, California, University of California Press, 568 p.

Steiger, R.H., and Jäger, E., 1977, Subcommission on geochronology - Convention on the use of decay constants in the geo- and cosmochronology: Earth and Planetary Science Letters, v. 36, no. 3, p. 359-362, doi:10.1016/0012821X(77)90060-7.

Stein, M., and Hofmann, A.W., 1992, Fossil plume head beneath the Arabian lithosphere?: Earth and Planetary Science Letters, v. 114, no. 1, p. 193-209, doi:10.1016/0012821X(92)90161-N

Stelten, M.E., Downs, D.T., Dietterich, H.R., Mahood, G.A., Calvert, A.T., Sisson, T.W., Zahran, H., and Shawali, J., 2018, Timescales of magmatic differentiation from alkali basalt to trachyte within the Harrat Rahat volcanic field, Kingdom of Saudi Arabia: Contributions to Mineralogy and Petrology, v. 173, no. 68, 17 p., doi:10.1007/s00410018-1495-9.

Stern, R.J., 1994, Arc assembly and continental collision in the Neoproterozoic East African Orogen-Implications for the consolidation of Gondwanaland: Annual Reviews of Earth and Planetary Sciences, v. 22, no. 1, p. 319-351, doi:10.1146/annurev.ea.22.050194.001535.

Stern, R.J., and Johnson, P., 2010, Continental lithosphere of the Arabian Plate - A geologic, petrologic, and geophysical synthesis: Earth-Science Reviews, v. 101, no. 1, p. 29-67, doi:10.1016/j.earscirev.2010.01.002.

Stoeser, D.B., and Camp, V.E., 1985, Pan-African microplate accretion of the Arabian Shield: Geological Society of America Bulletin, v. 96, no. 7, p. 817-826, doi:10.1130/0016-7606(1985)96<817:PMAOTA>2.0.CO;2.

Stone, J., 2000, Air pressure and cosmogenic isotope production: Journal of Geophysical Research, v. 105, no. B10, p. 23,75323,760, doi:10.1029/2000JB900181.

Taggart, J.E., Jr., ed., 2002, Analytical methods for chemical analysis of geologic and other materials, U.S. Geological Survey: U.S. Geological Survey Open-File Report 2002223, 20 p., https://pubs.usgs.gov/of/2002/ofr-02-0223/.

Yao, Z., Mooney, W.D., Zahran, H.M., and Youssef, S.E., 2017, Upper mantle velocity structure beneath the Arabian shield from Rayleigh surface wave tomography and its implications: Journal of Geophysical Research, v. 122, no. 8, p. 6552-6568, doi:10.1002/2016JB013805.

Ziab, A.A., and Ramsay, C.R., 1986, Geologic map of the Turabah quadrangle, sheet 21E, Kingdom of Saudi Arabia: Saudi Arabian Deputy Ministry for Mineral Resources Geoscience Map GM-93C, scale 1:250,000, 35 p. 
Table 1. Map units in northern Harrat Rahat volcanic field, listed alphabetially by unit label, showing their unit names, ages, and eruptive stages.

\begin{tabular}{|c|c|c|}
\hline Unit label & Unit name (and age) & Eruptive stage or section heading \\
\hline al & Modern alluvium (Quaternary) & Surficial deposits \\
\hline baaj & Basalt of Abar Al Julud (middle Pleistocene) & Eruptive stage 9 (360 to $460 \mathrm{ka}$ ) \\
\hline bada & Basalt of Ad Dayyir (middle Pleistocene) & Eruptive stage 10 (460 to $570 \mathrm{ka}$ ) \\
\hline badb & Basalt of Al Adhbah (middle Pleistocene) & Eruptive stage 6 (180 to $260 \mathrm{ka}$ ) \\
\hline badh & Basalt of Adh Dhiyabah (middle Pleistocene) & Eruptive stage 6 (180 to $260 \mathrm{ka}$ ) \\
\hline bag & Basalt of Abu Ghuwayshiyah (middle Pleistocene) & Eruptive stage 6 (180 to $260 \mathrm{ka})$ \\
\hline bahu & Basalt of Al Hulays (middle Pleistocene) & Eruptive stage 6 (180 to $260 \mathrm{ka})$ \\
\hline bai & Basalt of Al Ihn (middle Pleistocene) & Eruptive stage 10 (460 to $570 \mathrm{ka}$ ) \\
\hline bam1 & Basalt of Amlit 1 (middle Pleistocene) & Eruptive stage 6 (180 to $260 \mathrm{ka})$ \\
\hline bam2 & Basalt of Amlit 2 (middle Pleistocene) & Eruptive stage 6 (180 to $260 \mathrm{ka})$ \\
\hline bam3 & Basalt of Amlit 3 (middle Pleistocene) & Eruptive stage 6 (180 to $260 \mathrm{ka}$ ) \\
\hline bam4 & Basalt of Amlit 4 (middle Pleistocene) & Eruptive stage 6 (180 to $260 \mathrm{ka}$ ) \\
\hline baq & Basalt of Al Qurdi (middle Pleistocene) & Eruptive stage 9 (360 to $460 \mathrm{ka}$ ) \\
\hline bar & Basalt of Abu Rimthah (late Pleistocene) & Eruptive stage 5 (100 to $180 \mathrm{ka}$ ) \\
\hline bara & Basalt of Ar Ra (middle Pleistocene) & Eruptive stage 10 (460 to $570 \mathrm{ka}$ ) \\
\hline bas & Basalt of Abu Sidrah (middle Pleistocene) & Eruptive stage 11 (570 to $780 \mathrm{ka}$ ) \\
\hline bash & Basalt of Ash Shamali (middle Pleistocene) & Eruptive stage 7 (260 to $323 \mathrm{ka}$ ) \\
\hline basu & Basalt of As Sumak (middle Pleistocene) & Eruptive stage 9 (360 to $460 \mathrm{ka}$ ) \\
\hline bat & Basalt of Atiq (middle Pleistocene) & Eruptive stage 11 (570 to $780 \mathrm{ka}$ ) \\
\hline bau & Basalt of An Nughayr (middle Pleistocene) & Eruptive stage 7 (260 to $323 \mathrm{ka}$ ) \\
\hline bawa & Basalt of Al Wabarah (middle Pleistocene) & Eruptive stage 6 (180 to $260 \mathrm{ka})$ \\
\hline bay & Basalt of Atiyah (middle Pleistocene) & Eruptive stage 9 (360 to $460 \mathrm{ka}$ ) \\
\hline bba & Basalt of Al Bayadah (middle Pleistocene) & Eruptive stage 11 (570 to $780 \mathrm{ka}$ ) \\
\hline bbd & Basalt of Banthane Dam (middle Pleistocene) & Eruptive stage 6 (180 to $260 \mathrm{ka})$ \\
\hline $\mathrm{bbr}$ & Basalt of Al Buraysha (middle Pleistocene) & Eruptive stage 6 (180 to $260 \mathrm{ka}$ ) \\
\hline bbsh & Basalt below Ash Shamali (middle Pleistocene) & Eruptive stage 10 (460 to $570 \mathrm{ka}$ ) \\
\hline bcef & Basalt of Central Finger (late Pleistocene) & Eruptive stage 2 (11 to $45 \mathrm{ka})$ \\
\hline bd1 & Basalt of Dabaa 1 (middle Pleistocene) & Eruptive stage 11 (570 to $780 \mathrm{ka}$ ) \\
\hline bd3 & Basalt of Dabaa 3 (middle Pleistocene) & Eruptive stage 7 (260 to $323 \mathrm{ka}$ ) \\
\hline bda & Basalt of Ad Darah (middle Pleistocene) & Eruptive stage 6 (180 to $260 \mathrm{ka})$ \\
\hline bdg & Basalt of Duwayghir (middle Pleistocene) & Eruptive stage 9 (360 to $460 \mathrm{ka}$ ) \\
\hline $\mathrm{bdr}$ & Basalt of Dab Al Harus (middle Pleistocene) & Eruptive stage 6 (180 to $260 \mathrm{ka})$ \\
\hline bdu & Basalt of Al Du'aythah (late Pleistocene) & Eruptive stage 2 (11 to $45 \mathrm{ka})$ \\
\hline bduw & Basalt of Ad Duwayfi'ah (middle Pleistocene) & Eruptive stage 9 (360 to $460 \mathrm{ka}$ ) \\
\hline bdw & Basalt of Ad Duwaykhilah (late Pleistocene) & Eruptive stage 2 (11 to $45 \mathrm{ka})$ \\
\hline bdy & Basalt of Ad Dubaysiyah (middle Pleistocene) & Eruptive stage 5 (100 to $180 \mathrm{ka})$ \\
\hline bedh & Basalt east of Dab Al Harus (middle Pleistocene) & Eruptive stage 10 (460 to $570 \mathrm{ka})$ \\
\hline bef & Basalt of Al Efairia (middle Pleistocene) & Eruptive stage $10(460$ to $570 \mathrm{ka})$ \\
\hline besa & Basalt east of Al Shathaa (middle Pleistocene) & Eruptive stage 6 (180 to $260 \mathrm{ka}$ ) \\
\hline bfa & Basalt of Al Farash (middle Pleistocene) & Eruptive stage 10 (460 to $570 \mathrm{ka})$ \\
\hline bg1 & Basalt of Gura 1 (middle Pleistocene) & Eruptive stage 11 (570 to $780 \mathrm{ka}$ ) \\
\hline bg3 & Basalt of Gura 3 (early Pleistocene) & Eruptive stage 12 (780 to $1,200 \mathrm{ka})$ \\
\hline
\end{tabular}


Table 1. Map units in northern Harrat Rahat volcanic field, listed alphabetially by unit label, showing their unit names, ages, and eruptive stages.-Continued

\begin{tabular}{|c|c|c|}
\hline Unit label & Unit name (and age) & Eruptive stage or section heading \\
\hline bgh & Basalt of Ghadwar (early Pleistocene) & Eruptive stage 12 ( 780 to $1,200 \mathrm{ka}$ ) \\
\hline bgo & Basalt of Gorab (early Pleistocene) & Eruptive stage 12 (780 to $1,200 \mathrm{ka})$ \\
\hline bh10 & Basalt of Hill 1066 (middle Pleistocene) & Eruptive stage 5 (100 to $180 \mathrm{ka}$ ) \\
\hline bh81 & Basalt of Hill 810 (middle Pleistocene) & Eruptive stage 6 (180 to $260 \mathrm{ka}$ ) \\
\hline bh82 & Basalt of Hill 821 (middle Pleistocene) & Eruptive stage 10 (460 to $570 \mathrm{ka}$ ) \\
\hline bh83 & Basalt of Hill 838 (middle Pleistocene) & Eruptive stage 10 (460 to $570 \mathrm{ka}$ ) \\
\hline bh86 & Basalt of Hill 865 (middle Pleistocene) & Eruptive stage 7 (260 to $323 \mathrm{ka}$ ) \\
\hline bh87 & Basalt of Hill 870 (middle Pleistocene) & Eruptive stage 9 (360 to $460 \mathrm{ka}$ ) \\
\hline bh89 & Basalt of Hill 892 (early Pleistocene) & Eruptive stage 12 (780 to $1,200 \mathrm{ka})$ \\
\hline bha & Basalt of Hathm (middle Pleistocene) & Eruptive stage 10 (460 to $570 \mathrm{ka})$ \\
\hline bhag & Basalt of Hilayyat Ghuwayshiyah (middle Pleistocene) & Eruptive stage 7 (260 to $323 \mathrm{ka}$ ) \\
\hline bhb & Basalt of Hamra Al Bidun (middle Pleistocene) & Eruptive stage 6 (180 to $260 \mathrm{ka}$ ) \\
\hline bhc & Basalt of Half Cone (middle Pleistocene) & Eruptive stage 10 (460 to $570 \mathrm{ka})$ \\
\hline bhg & Basalt of Al Harrah Al Gharbiyah (middle Pleistocene) & Eruptive stage 9 (360 to $460 \mathrm{ka}$ ) \\
\hline bhin & Basalt of Al Hinu (middle Pleistocene) & Eruptive stage 10 (460 to $570 \mathrm{ka})$ \\
\hline bhm & Basalt of Al Humayra (middle Pleistocene) & Eruptive stage 7 (260 to $323 \mathrm{ka}$ ) \\
\hline bhq & Basalt of Sha'ib Huquf (middle Pleistocene) & Eruptive stage 10 (460 to $570 \mathrm{ka})$ \\
\hline bhu & Basalt of Al Huzaym (middle Pleistocene) & Eruptive stage 7 (260 to $323 \mathrm{ka}$ ) \\
\hline bhy & Basalt of Sha'ib Hayaya (middle Pleistocene) & Eruptive stage 6 (180 to $260 \mathrm{ka})$ \\
\hline bis & Basalt of Al Iskan (middle Pleistocene) & Eruptive stage 10 (460 to $570 \mathrm{ka})$ \\
\hline bja & Basalt of Al Jar'ah (middle Pleistocene) & Eruptive stage 11 (570 to $780 \mathrm{ka}$ ) \\
\hline bjab & Basalt of Jabal (middle Pleistocene) & Eruptive stage 8 (323 to $360 \mathrm{ka}$ ) \\
\hline bjb & Basalt of Al Janubi (middle Pleistocene) & Eruptive stage 5 (100 to $180 \mathrm{ka})$ \\
\hline bjg & Basalt of Al Jaga (middle Pleistocene) & Eruptive stage 10 (460 to $570 \mathrm{ka})$ \\
\hline bjn & Basalt of Al Jan (middle Pleistocene) & Eruptive stage 10 (460 to $570 \mathrm{ka}$ ) \\
\hline bjr & Basalt of Umm Jurmat (middle Pleistocene) & Eruptive stage 6 (180 to $260 \mathrm{ka}$ ) \\
\hline bjs & Basalt of Al Jassah (middle Pleistocene) & Eruptive stage 6 (180 to $260 \mathrm{ka})$ \\
\hline bju & Basalt of Al Jurb (middle Pleistocene) & Eruptive stage 9 (360 to $460 \mathrm{ka}$ ) \\
\hline bka & Basalt of Al Khanaq (middle Pleistocene) & Eruptive stage 5 (100 to $180 \mathrm{ka})$ \\
\hline bkf & Basalt of Al Khafaq (middle Pleistocene) & Eruptive stage 10 (460 to $570 \mathrm{ka})$ \\
\hline bla & Basalt of Al Labah (Holocene) & Eruptive stage 1 ( 0 to $11 \mathrm{ka})$ \\
\hline bli & Basalt of Al Billa'ah (middle Pleistocene) & Eruptive stage 6 (180 to $260 \mathrm{ka}$ ) \\
\hline blqa & Basalt of Lower Qa Al Aqul (middle Pleistocene) & Eruptive stage 6 (180 to $260 \mathrm{ka})$ \\
\hline blqh & Basalt of Lower Qa Hadawda (middle Pleistocene) & Eruptive stage 6 (180 to $260 \mathrm{ka}$ ) \\
\hline blsa & Basalt of Lower Sahab (middle Pleistocene) & Eruptive stage 8 (323 to $360 \mathrm{ka}$ ) \\
\hline blsl & Basalt of Lower Sha'ib Lihyan (middle Pleistocene) & Eruptive stage 6 (180 to $260 \mathrm{ka})$ \\
\hline bm1 & Basalt of Al Malsaa 1 (middle Pleistocene) & Eruptive stage 6 (180 to $260 \mathrm{ka})$ \\
\hline bm2 & Basalt of Al Malsaa 2 (middle Pleistocene) & Eruptive stage 5 (100 to $180 \mathrm{ka})$ \\
\hline bmat & Basalt of Mahd Adh Thahab Road (middle Pleistocene) & Eruptive stage 5 (100 to $180 \mathrm{ka}$ ) \\
\hline bmd & Basalt of Al Madba'ah (middle Pleistocene) & Eruptive stage 6 (180 to $260 \mathrm{ka}$ ) \\
\hline bme & Basalt of Al Mesba'ah (middle Pleistocene) & Eruptive stage 6 (180 to $260 \mathrm{ka})$ \\
\hline bmg & Basalt of Al Mughatiyah (middle Pleistocene) & Eruptive stage 10 (460 to $570 \mathrm{ka}$ ) \\
\hline
\end{tabular}


Table 1. Map units in northern Harrat Rahat volcanic field, listed alphabetially by unit label, showing their unit names, ages, and eruptive stages.-Continued

\begin{tabular}{|c|c|c|}
\hline Unit label & Unit name (and age) & Eruptive stage or section heading \\
\hline bmh & Basalt of Al Muq'iyah (middle Pleistocene) & Eruptive stage 10 (460 to $570 \mathrm{ka})$ \\
\hline bmk & Basalt of Mukhayar (middle Pleistocene) & Eruptive stage 7 (260 to $323 \mathrm{ka}$ ) \\
\hline bml & Basalt of Al Mulaysa (middle Pleistocene) & Eruptive stage 6 (180 to $260 \mathrm{ka})$ \\
\hline bms & Basalt of Musawda'ah (late Pleistocene) & Eruptive stage 3 (45 to $70 \mathrm{ka}$ ) \\
\hline bmsm & Basalt of Al Musamma (middle Pleistocene) & Eruptive stage 10 (460 to $570 \mathrm{ka})$ \\
\hline bmt & Basalt of Matan (middle Pleistocene) & Eruptive stage 6 (180 to $260 \mathrm{ka})$ \\
\hline bmu & Basalt of Al Mustarah (middle Pleistocene & Eruptive stage 8 (323 to $360 \mathrm{ka}$ ) \\
\hline bmuf & Basalt of Al Mufayriq (middle Pleistocene) & Eruptive stage 9 (360 to $460 \mathrm{ka}$ ) \\
\hline bmus & Basalt of Muslimah (middle Pleistocene) & Eruptive stage 9 (360 to $460 \mathrm{ka})$ \\
\hline bmy & Basalt of Al Matyan (middle Pleistocene) & Eruptive stage $11(570$ to $780 \mathrm{ka})$ \\
\hline $\mathrm{bmz}$ & Basalt of Al Muzayyin (middle Pleistocene) & Eruptive stage 5 (100 to $180 \mathrm{ka})$ \\
\hline bna & Basalt of Nabta (middle Pleistocene) & Eruptive stage 5 (100 to $180 \mathrm{ka})$ \\
\hline bnar & Basalt north of Abu Rimthah (middle Pleistocene) & Eruptive stage 5 (100 to $180 \mathrm{ka})$ \\
\hline bnh & Basalt of Al Negea'ah (middle Pleistocene) & Eruptive stage 9 (360 to $460 \mathrm{ka})$ \\
\hline bni & Basalt north of Iskabah (middle Pleistocene) & Eruptive stage 9 (360 to $460 \mathrm{ka}$ ) \\
\hline bnj & Basalt north of Al Jufdirah (middle Pleistocene) & Eruptive stage 9 (360 to $460 \mathrm{ka}$ ) \\
\hline bnof & Basalt of Northern Fingers (late Pleistocene) & Eruptive stage 2 (11 to $45 \mathrm{ka})$ \\
\hline bns & Basalt of Nashbah (middle Pleistocene) & Eruptive stage 5 (100 to $180 \mathrm{ka})$ \\
\hline bnu & Basalt of Nubala (late Pleistocene) & Eruptive stage 5 (100 to $180 \mathrm{ka})$ \\
\hline bpr & Basalt of Powerline Road (middle Pleistocene) & Eruptive stage 9 (360 to $460 \mathrm{ka})$ \\
\hline bqa & Basalt of Al Qafif (early Pleistocene) & Eruptive stage 12 ( 780 to $1,200 \mathrm{ka})$ \\
\hline bqaq & Basalt of Qa Al Qina'ah (middle Pleistocene) & Eruptive stage 7 (260 to $323 \mathrm{ka})$ \\
\hline bqar & Basalt of Al Qara'in (middle Pleistocene) & Eruptive stage 6 (180 to $260 \mathrm{ka})$ \\
\hline bqg & Basalt of Qa Al Ghusun (middle Pleistocene) & Eruptive stage 6 (180 to $260 \mathrm{ka}$ ) \\
\hline bqi & Basalt of Al Qirayy (middle Pleistocene) & Eruptive stage 9 (360 to $460 \mathrm{ka})$ \\
\hline bqr & Basalt of Quraydah (middle Pleistocene) & Eruptive stage 9 (360 to $460 \mathrm{ka})$ \\
\hline bqu & Basalt of Quba (middle Pleistocene) & Eruptive stage 10 (460 to $570 \mathrm{ka})$ \\
\hline bra & Basalt of Al Rafi'ah (middle Pleistocene) & Eruptive stage 5 (100 to $180 \mathrm{ka})$ \\
\hline brag & Basalt of Ar Raghibah (middle Pleistocene) & Eruptive stage 10 (460 to $570 \mathrm{ka})$ \\
\hline brb & Basalt of Rawd Al Baham (middle Pleistocene) & Eruptive stage 9 (360 to $460 \mathrm{ka}$ ) \\
\hline brg & Basalt of Um Rgaibah (middle Pleistocene) & Eruptive stage 10 (460 to $570 \mathrm{ka}$ ) \\
\hline brh & Basalt of Rahat (middle Pleistocene) & Eruptive stage 9 (360 to $460 \mathrm{ka})$ \\
\hline bri & Basalt of Ar Ritajah (middle Pleistocene) & Eruptive stage 9 (360 to $460 \mathrm{ka})$ \\
\hline brt & Basalt of Radio Tower (middle Pleistocene) & Eruptive stage 5 (100 to $180 \mathrm{ka}$ ) \\
\hline bru & Basalt of Ar Rummanah (middle Pleistocene) & Eruptive stage 6 (180 to $260 \mathrm{ka})$ \\
\hline brum & Basalt of Ar Rumahiyah (middle Pleistocene) & Eruptive stage 9 (360 to $460 \mathrm{ka}$ ) \\
\hline brw & Basalt of Ruwawah (middle Pleistocene) & Eruptive stage 9 (360 to $460 \mathrm{ka})$ \\
\hline bsa & Basalt of Al Shathaa (middle Pleistocene) & Eruptive stage 7 (260 to $323 \mathrm{ka}$ ) \\
\hline bsah & Basalt of Shi'ban Al Hulaysiwat (middle Pleistocene) & Eruptive stage 9 (360 to $460 \mathrm{ka}$ ) \\
\hline bsam & Basalt of Sha'ib Al Maqrin (middle Pleistocene) & Eruptive stage 9 (360 to $460 \mathrm{ka}$ ) \\
\hline bsas & Basalt of Shai’ab Abu Sikhbir (late Pleistocene) & Eruptive stage 5 (100 to $180 \mathrm{ka})$ \\
\hline bsaw & Basalt of Sha'ib Al Wuqayt (middle Pleistocene) & Eruptive stage 9 (360 to $460 \mathrm{ka}$ ) \\
\hline
\end{tabular}


Table 1. Map units in northern Harrat Rahat volcanic field, listed alphabetially by unit label, showing their unit names, ages, and eruptive stages.-Continued

\begin{tabular}{|c|c|c|}
\hline Unit label & Unit name (and age) & Eruptive stage or section heading \\
\hline bsb & Basalt of Sha'ib Banthane (middle Pleistocene) & Eruptive stage 5 (100 to $180 \mathrm{ka})$ \\
\hline bsd & Basalt of Sha'ib Ad Dirwah (middle Pleistocene) & Eruptive stage 11 (570 to $780 \mathrm{ka})$ \\
\hline bsf & Basalt of Umm Sufar (middle Pleistocene) & Eruptive stage 6 (180 to $260 \mathrm{ka})$ \\
\hline bsh & Basalt of Shuran (middle Pleistocene) & Eruptive stage 6 (180 to $260 \mathrm{ka}$ ) \\
\hline bsi & Basalt of Sha'ib Iskabah (middle Pleistocene) & Eruptive stage 5 (100 to $180 \mathrm{ka})$ \\
\hline bsj & Basalt south of Al Jufdirah (middle Pleistocene) & Eruptive stage 8 ( 323 to $360 \mathrm{ka}$ ) \\
\hline bsk & Basalt of Sha'ib Al Khakh (late Pleistocene) & Eruptive stage 4 (70 to $100 \mathrm{ka}$ ) \\
\hline bsl & Basalt of Sha'ib Luwa (middle Pleistocene) & Eruptive stage $11(570$ to $780 \mathrm{ka})$ \\
\hline bsm & Basalt of Sha'ib Murayyikh (middle Pleistocene) & Eruptive stage 8 (323 to $360 \mathrm{ka}$ ) \\
\hline bso & Basalt of South (middle Pleistocene) & Eruptive stage 6 (180 to $260 \mathrm{ka})$ \\
\hline bsof & Basalt of Southern Fingers (late Pleistocene) & Eruptive stage 2 (11 to $45 \mathrm{ka})$ \\
\hline bsou & Basalt of Southwest (middle Pleistocene) & Eruptive stage 9 (360 to $460 \mathrm{ka}$ ) \\
\hline bsq & Basalt of Ash Suqayyiqah (middle Pleistocene) & Eruptive stage 5 (100 to $180 \mathrm{ka})$ \\
\hline bss & Basalt of Sha'ib Si'ayd (middle Pleistocene) & Eruptive stage 10 (460 to $570 \mathrm{ka})$ \\
\hline bssu & Basalt south of As Sumak (middle Pleistocene) & Eruptive stage 7 (260 to $323 \mathrm{ka}$ ) \\
\hline bsu & Basalt of As Suddiyah (late Pleistocene) & Eruptive stage 4 (70 to $100 \mathrm{ka}$ ) \\
\hline bsuy & Basalt of Umm Suyuf (middle Pleistocene) & Eruptive stage 7 (260 to $323 \mathrm{ka})$ \\
\hline bsw & Basalt of Umm Suwasi (middle Pleistocene) & Eruptive stage $11(570$ to $780 \mathrm{ka})$ \\
\hline bswu & Basalt of Sha'ib Al Wuqayyit (middle Pleistocene) & Eruptive stage 9 (360 to $460 \mathrm{ka}$ ) \\
\hline bsy & Basalt of Abu Siyilah (middle Pleistocene) & Eruptive stage 6 (180 to $260 \mathrm{ka})$ \\
\hline bte & Basalt of Abu Tunaydibah East (middle Pleistocene) & Eruptive stage 9 (360 to $460 \mathrm{ka}$ ) \\
\hline btw & Basalt of Abu Tunaydibah West (middle Pleistocene) & Eruptive stage 10 (460 to $570 \mathrm{ka})$ \\
\hline buaa & Basalt of Umm Al Awshaz (middle Pleistocene) & Eruptive stage 6 (180 to $260 \mathrm{ka})$ \\
\hline buak & Basalt of Umm Arakah (middle Pleistocene) & Eruptive stage 6 (180 to $260 \mathrm{ka}$ ) \\
\hline buh & Basalt of Umm Hamd (middle Pleistocene) & Eruptive stage 9 (360 to $460 \mathrm{ka})$ \\
\hline buj & Basalt of Umm Ja'adat (middle Pleistocene) & Eruptive stage 9 (360 to $460 \mathrm{ka})$ \\
\hline bun & Basalt of Umm Nathilah (late Pleistocene) & Eruptive stage 5 (100 to $180 \mathrm{ka}$ ) \\
\hline buph & Basalt of Upper Sha'ib Huquf (middle Pleistocene) & Eruptive stage 10 (460 to $570 \mathrm{ka})$ \\
\hline bups & Basalt of Upper Sahab (middle Pleistocene) & Eruptive stage 6 (180 to $260 \mathrm{ka})$ \\
\hline buq & Basalt of Umm Qubayr (middle Pleistocene) & Eruptive stage 11 (570 to $780 \mathrm{ka}$ ) \\
\hline buqa & Basalt of Upper Qa Al Aqul (early Pleistocene) & Eruptive stage 12 (780 to $1,200 \mathrm{ka})$ \\
\hline buqh & Basalt of Upper Qa Hadawda (middle Pleistocene) & Eruptive stage 6 (180 to $260 \mathrm{ka})$ \\
\hline bur & Basalt of Al Urayd (middle Pleistocene) & Eruptive stage 9 (360 to $460 \mathrm{ka}$ ) \\
\hline buri & Basalt of Upper Ar Ritajah (middle Pleistocene) & Eruptive stage 6 (180 to $260 \mathrm{ka})$ \\
\hline burr & Basalt of Upper Abu Rimthah (middle Pleistocene) & Eruptive stage 9 (360 to $460 \mathrm{ka}$ ) \\
\hline buru & Basalt of Umm Rutaj (middle Pleistocene) & Eruptive stage 6 (180 to $260 \mathrm{ka})$ \\
\hline busa & Basalt of Al Ushayrah (middle Pleistocene) & Eruptive stage 9 (360 to $460 \mathrm{ka}$ ) \\
\hline busb & Basalt of Al Usbu'ah (middle Pleistocene) & Eruptive stage 7 (260 to $323 \mathrm{ka}$ ) \\
\hline bush & Basalt of Al Ushu'a (middle Pleistocene) & Eruptive stage 11 (570 to $780 \mathrm{ka})$ \\
\hline busi & Basalt of Upper Sha'ib Iskabah (middle Pleistocene) & Eruptive stage 6 (180 to $260 \mathrm{ka})$ \\
\hline busm & Basalt of Upper Sha'ib Murayyikh (middle Pleistocene) & Eruptive stage 10 (460 to $570 \mathrm{ka})$ \\
\hline busq & Basalt of Usquf (middle Pleistocene) & Eruptive stage 9 (360 to $460 \mathrm{ka})$ \\
\hline
\end{tabular}


Table 1. Map units in northern Harrat Rahat volcanic field, listed alphabetially by unit label, showing their unit names, ages, and eruptive stages.-Continued

\begin{tabular}{|c|c|c|}
\hline Unit label & Unit name (and age) & Eruptive stage or section heading \\
\hline bwar & Basalt west of Abu Rimthah (middle Pleistocene) & Eruptive stage 5 (100 to $180 \mathrm{ka})$ \\
\hline bwh8 & Basalt west of Hill 870 (middle Pleistocene) & Eruptive stage 6 (180 to $260 \mathrm{ka})$ \\
\hline bwhu & Basalt west of Al Hurus (middle Pleistocene) & Eruptive stage 10 (460 to $570 \mathrm{ka})$ \\
\hline bwm & Basalt west of Matan (middle Pleistocene) & Eruptive stage 5 (100 to $180 \mathrm{ka})$ \\
\hline bya & Basalt of Yalla (middle Pleistocene) & Eruptive stage 7 (260 to $323 \mathrm{ka}$ ) \\
\hline byid & Basalt of Yidum (middle Pleistocene) & Eruptive stage 10 (460 to $570 \mathrm{ka})$ \\
\hline bza & Basalt of Az Zanat (late Pleistocene) & Eruptive stage 5 (100 to $180 \mathrm{ka})$ \\
\hline bzi & Basalt of Az Zinitah (middle Pleistocene) & Eruptive stage 10 (460 to $570 \mathrm{ka})$ \\
\hline han1 & Hawaiite of Al Anahi 1 (middle Pleistocene) & Eruptive stage 5 (100 to $180 \mathrm{ka})$ \\
\hline han2 & Hawaiite of Al Anahi 2 (late Pleistocene) & Eruptive stage 4 (70 to $100 \mathrm{ka})$ \\
\hline han3 & Hawaiite of Al Anahi 3 (late Pleistocene) & Eruptive stage 3 ( 45 to $70 \mathrm{ka}$ ) \\
\hline har & Hawaiite of Abu Rimthah (middle Pleistocene) & Eruptive stage 5 (100 to $180 \mathrm{ka}$ ) \\
\hline hd2 & Hawaiite of Dabaa 2 (late or middle Pleistocene) & Eruptive stage 5 (100 to $180 \mathrm{ka})$ \\
\hline hhil & Hawaiite of Hilayyat (middle Pleistocene) & Eruptive stage 10 (460 to $570 \mathrm{ka})$ \\
\hline hkh & Hawaiite of Khamisah (late Pleistocene) & Eruptive stage 2 (11 to $45 \mathrm{ka}$ ) \\
\hline hlh & Hawaiite of Al Lihyan (middle Pleistocene) & Eruptive stage 5 (100 to $180 \mathrm{ka})$ \\
\hline $\mathrm{hm} 3$ & Hawaiite of Al Malsaa 3 (middle Pleistocene) & Eruptive stage 5 (100 to $180 \mathrm{ka})$ \\
\hline hma & Hawaiite of Al Malsa (middle Pleistocene) & Eruptive stage 6 (180 to $260 \mathrm{ka})$ \\
\hline $\mathrm{hmk}$ & Hawaiite of Mukhayar (middle Pleistocene) & Eruptive stage 6 (180 to $260 \mathrm{ka})$ \\
\hline hmo & Hawaiite of Mouteen (middle Pleistocene) & Eruptive stage 6 (180 to $260 \mathrm{ka}$ ) \\
\hline hsb & Hawaiite of As Sabah (middle Pleistocene) & Eruptive stage 9 (360 to $460 \mathrm{ka})$ \\
\hline masu & Mugearite of As Sumak (middle Pleistocene) & Eruptive stage 6 (180 to $260 \mathrm{ka})$ \\
\hline md1 & Mugearite of Dabaa 1 (late Pleistocene) & Eruptive stage 5 (100 to $180 \mathrm{ka})$ \\
\hline $\operatorname{mh11}$ & Mugearite of Hill 1125 (late Pleistocene) & Eruptive stage 4 (70 to $100 \mathrm{ka})$ \\
\hline mha & Mugearite of Al Harara (middle Pleistocene) & Eruptive stage 9 (360 to $460 \mathrm{ka})$ \\
\hline $\mathrm{mma}$ & Mugearite of Matan (middle Pleistocene) & Eruptive stage 5 (100 to $180 \mathrm{ka}$ ) \\
\hline $\mathrm{mmk}$ & Mugearite of Mukhayar (late Pleistocene) & Eruptive stage 5 (100 to $180 \mathrm{ka})$ \\
\hline $\mathrm{mmu}$ & Mugearite of Al Mulaysa (middle Pleistocene) & Eruptive stage 6 (180 to $260 \mathrm{ka})$ \\
\hline mmy & Mugearite of Murayyikh (middle Pleistocene) & Eruptive stage 6 (180 to $260 \mathrm{ka})$ \\
\hline mns & Mugearite northwest of Al Shathaa (middle Pleistocene) & Eruptive stage 9 (360 to $460 \mathrm{ka}$ ) \\
\hline mnzy & Mugearite north of As Zayinah (middle Pleistocene) & Eruptive stage 9 (360 to $460 \mathrm{ka}$ ) \\
\hline msi & Mugearite of Sha'ib Abu Sidrah (middle Pleistocene) & Eruptive stage 9 (360 to $460 \mathrm{ka}$ ) \\
\hline $\mathrm{msr}$ & Mugearite of Sha'ib Rushayyah (middle Pleistocene) & Eruptive stage 9 (360 to $460 \mathrm{ka}$ ) \\
\hline mss & Mugearite southwest of Al Shathaa (middle Pleistocene) & Eruptive stage $11(570$ to $780 \mathrm{ka})$ \\
\hline muq & Mugearite of Umm Qurah (middle Pleistocene) & Eruptive stage 9 (360 to $460 \mathrm{ka}$ ) \\
\hline murr & Mugearite of Umm Ar Rish (middle Pleistocene) & Eruptive stage 6 (180 to $260 \mathrm{ka})$ \\
\hline $\mathrm{mz2}$ & Mugearite of Um Znabah 2 (middle Pleistocene) & Eruptive stage 6 (180 to $260 \mathrm{ka})$ \\
\hline mz3 & Mugearite of Um Znabah 3 (middle Pleistocene) & Eruptive stage 9 (360 to $460 \mathrm{ka}$ ) \\
\hline mz6 & Mugearite of Um Znabah 6 (middle Pleistocene) & Eruptive stage 9 (360 to $460 \mathrm{ka}$ ) \\
\hline mzy & Mugearite of As Zayinah (middle Pleistocene) & Eruptive stage 9 (360 to $460 \mathrm{ka}$ ) \\
\hline oba & Benmoreite of Al Bayadah (middle Pleistocene) & Eruptive stage 6 (180 to $260 \mathrm{ka}$ ) \\
\hline og2 & Benmoreite of Gura 2 (late Pleistocene) & Eruptive stage 5 (100 to $180 \mathrm{ka})$ \\
\hline
\end{tabular}


Table 1. Map units in northern Harrat Rahat volcanic field, listed alphabetially by unit label, showing their unit names, ages, and eruptive stages.-Continued

\begin{tabular}{|c|c|c|}
\hline Unit label & Unit name (and age) & Eruptive stage or section heading \\
\hline og3 & Benmoreite of Gura 3 (middle Pleistocene) & Eruptive stage 10 (460 to $570 \mathrm{ka})$ \\
\hline og4 & Benmoreite of Gura 4 (middle Pleistocene) & Eruptive stage 7 (260 to $323 \mathrm{ka}$ ) \\
\hline oju & Benmoreite of Um Junb (middle Pleistocene) & Eruptive stage 9 (360 to $460 \mathrm{ka}$ ) \\
\hline oma & Benmoreite of Al Malsaa (middle Pleistocene) & Eruptive stage 6 (180 to $260 \mathrm{ka}$ ) \\
\hline oqa & Benmoreite of Al Qara'in (middle Pleistocene) & Eruptive stage 5 (100 to $180 \mathrm{ka})$ \\
\hline ort & Benmoreite of Radio Tower (middle Pleistocene) & Eruptive stage 5 (100 to $180 \mathrm{ka})$ \\
\hline osa & Benmoreite of Al Shathaa (middle Pleistocene) & Eruptive stage 9 (360 to $460 \mathrm{ka})$ \\
\hline osb & Benmoreite of As Sabah (middle Pleistocene) & Eruptive stage 10 (460 to $570 \mathrm{ka}$ ) \\
\hline oz4 & Benmoreite of Um Znabah 4 (middle Pleistocene) & Eruptive stage 9 (360 to $460 \mathrm{ka})$ \\
\hline oz5 & Benmoreite of Um Znabah 5 (middle Pleistocene) & Eruptive stage 9 (360 to $460 \mathrm{ka}$ ) \\
\hline ozy & Benmoreite of As Zayinah (middle Pleistocene) & Eruptive stage 9 (360 to $460 \mathrm{ka})$ \\
\hline p€ & Precambrian rocks (Precambrian) & Precambrian rocks \\
\hline Qal & Alluvium (Quaternary) & Surficial deposits \\
\hline Qbhk & Basalt of Harrat Kurama (early Pleistocene) & Volcanic rocks of Harrat Kurama \\
\hline Qbjs & Basalt of Jabal Umm Suhaylah (early Pleistocene) & Volcanic rocks of Harrat Kurama \\
\hline Qbra & Basalt of Ar Ramram (early Pleistocene) & Volcanic rocks of Harrat Kurama \\
\hline Tbja & Basalt of Jabal Ayr (Miocene) & Tertiary volcanic rocks \\
\hline Tbjj & Basalt of Jabal Jammah (Miocene) & Tertiary volcanic rocks \\
\hline td1 & Trachyte of Dabaa 1 (late Pleistocene) & Eruptive stage 2 (11 to $45 \mathrm{ka})$ \\
\hline tef & Trachyte of Al Efairia (late Pleistocene) & Eruptive stage 4 (70 to $100 \mathrm{ka})$ \\
\hline $\operatorname{tg} 2$ & Trachyte of Gura 2 (late Pleistocene) & Eruptive stage 4 (70 to $100 \mathrm{ka})$ \\
\hline $\operatorname{tg} 3$ & Trachyte of Gura 3 (middle Pleistocene) & Eruptive stage 5 (100 to $180 \mathrm{ka})$ \\
\hline $\operatorname{tg} 4$ & Trachyte of Gura 4 (late Pleistocene) & Eruptive stage 4 (70 to $100 \mathrm{ka})$ \\
\hline $\operatorname{tg} 5$ & Trachyte of Gura 5 (late Pleistocene) & Eruptive stage 4 (70 to $100 \mathrm{ka})$ \\
\hline tma & Trachyte of Matan (late Pleistocene) & Eruptive stage 5 (100 to $180 \mathrm{ka})$ \\
\hline tmo & Trachyte of Mouteen (late Pleistocene) & Eruptive stage 2 (11 to $45 \mathrm{ka})$ \\
\hline tqa & Trachyte of Al Qayf (middle Pleistocene) & Eruptive stage 9 (360 to $460 \mathrm{ka})$ \\
\hline $\operatorname{trg}$ & Trachyte of Um Rgaibah (Holocene) & Eruptive stage 1 ( 0 to $11 \mathrm{ka})$ \\
\hline twa & Trachyte of Al Wabarah (late Pleistocene) & Eruptive stage 2 (11 to $45 \mathrm{ka})$ \\
\hline $\mathrm{tz1}$ & Trachyte of Um Znabah 1 (middle Pleistocene) & Eruptive stage 7 (260 to $323 \mathrm{ka}$ ) \\
\hline tz2 & Trachyte of Um Znabah 2 (late Pleistocene) & Eruptive stage 5 (100 to $180 \mathrm{ka})$ \\
\hline tz6 & Trachyte of Um Znabah 6 (middle Pleistocene) & Eruptive stage 9 (360 to $460 \mathrm{ka}$ ) \\
\hline $\mathrm{v}$ & Undifferentiated vents (Quaternary) & Quaternary volcanic rocks \\
\hline
\end{tabular}




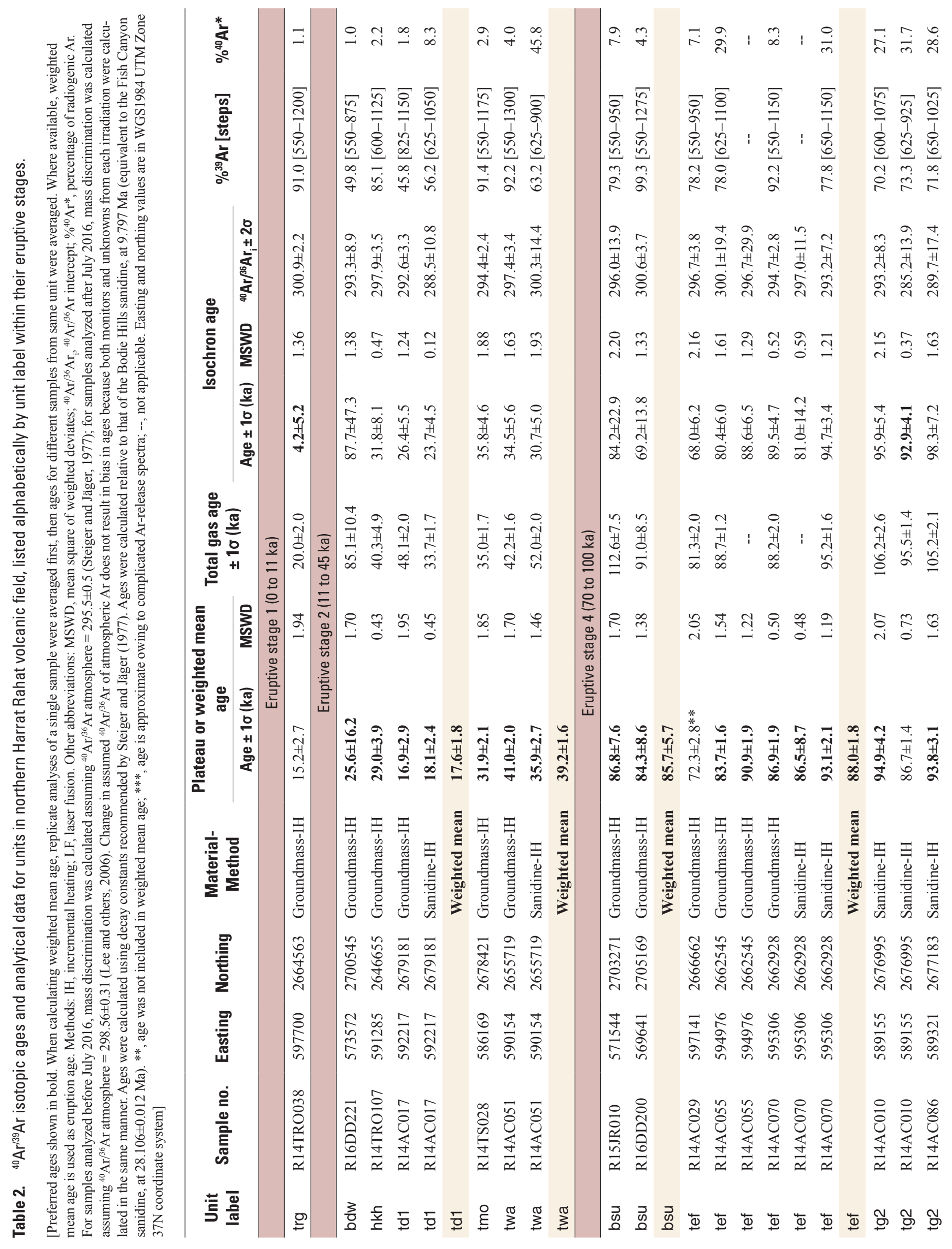




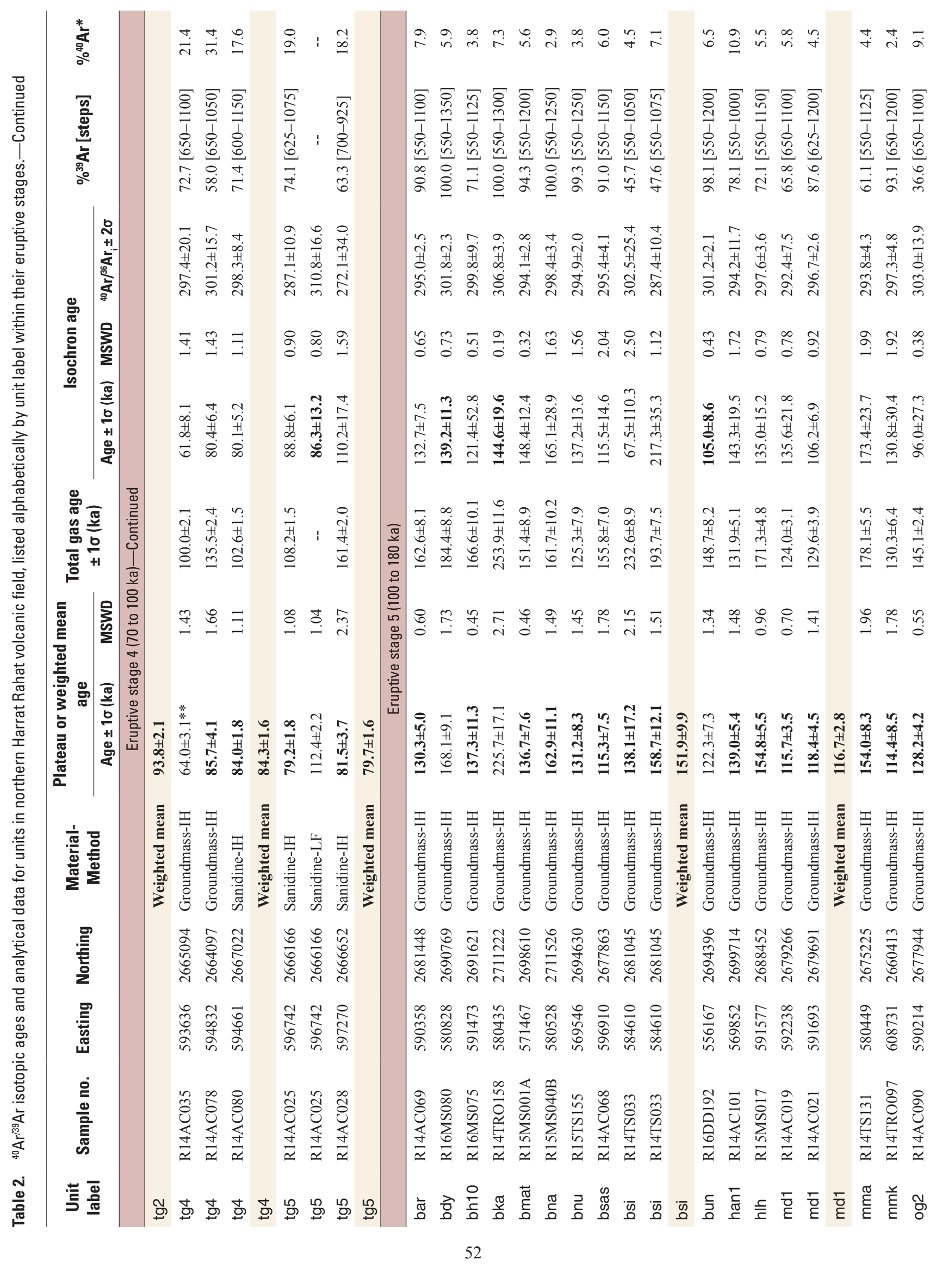




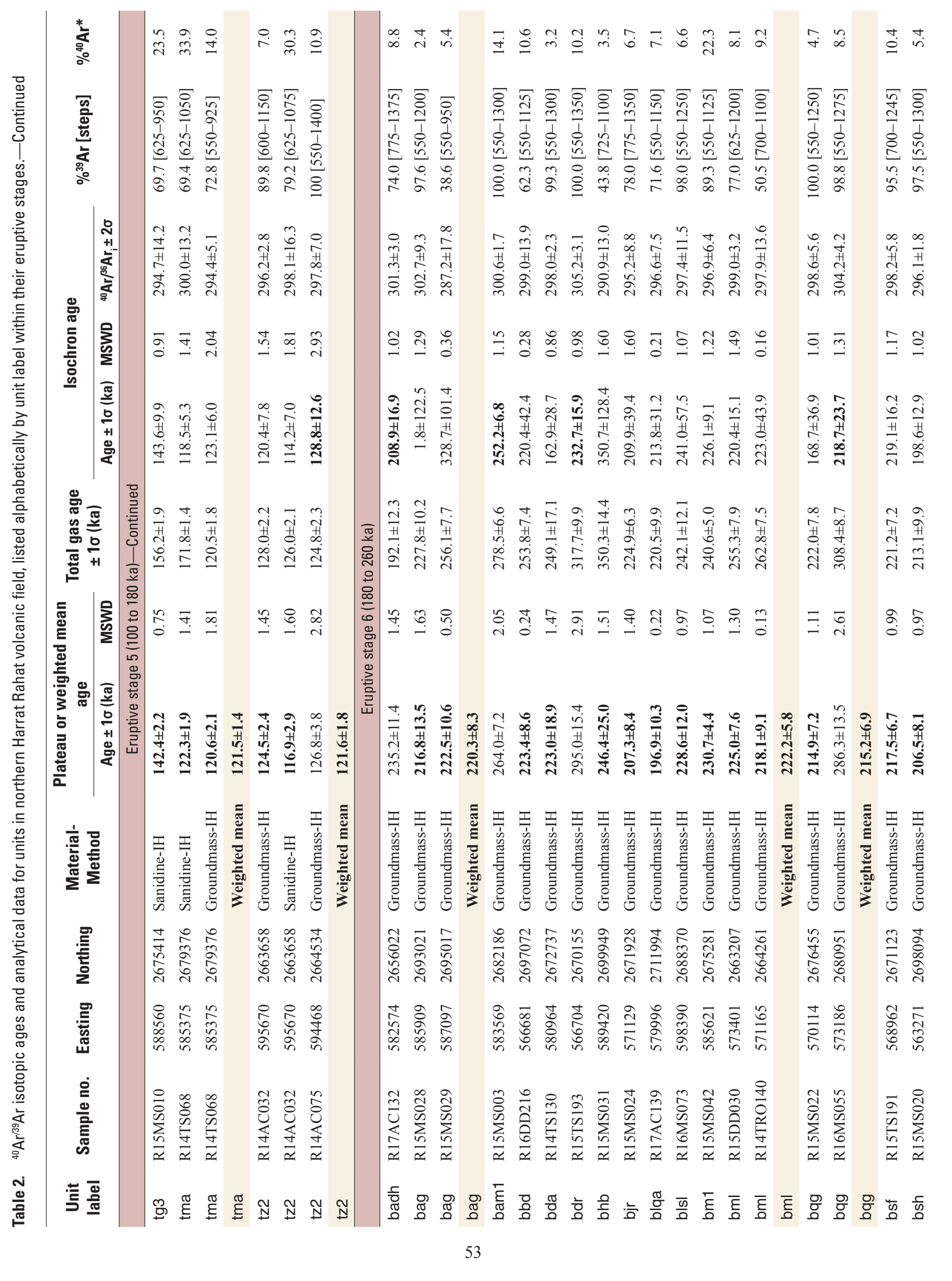




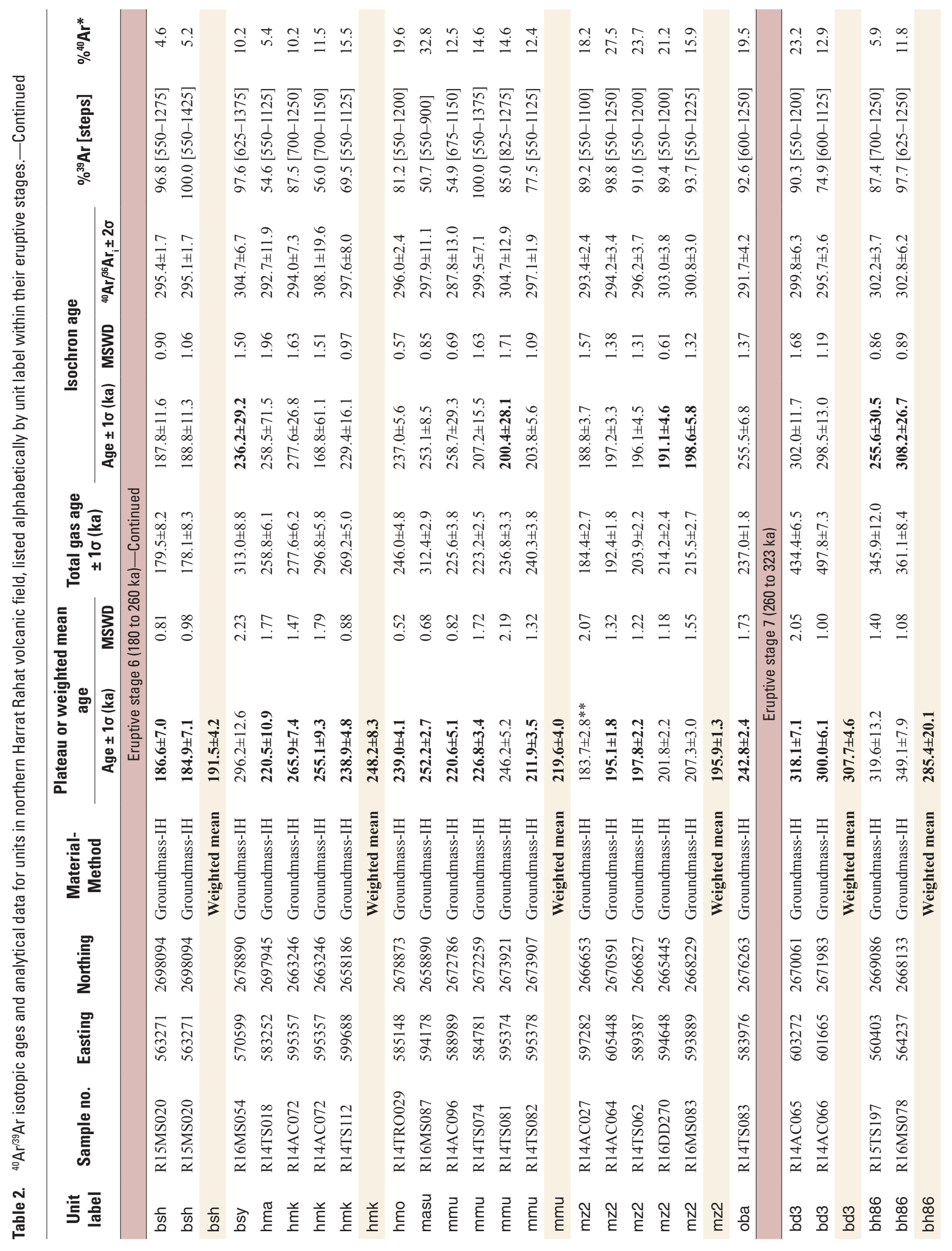




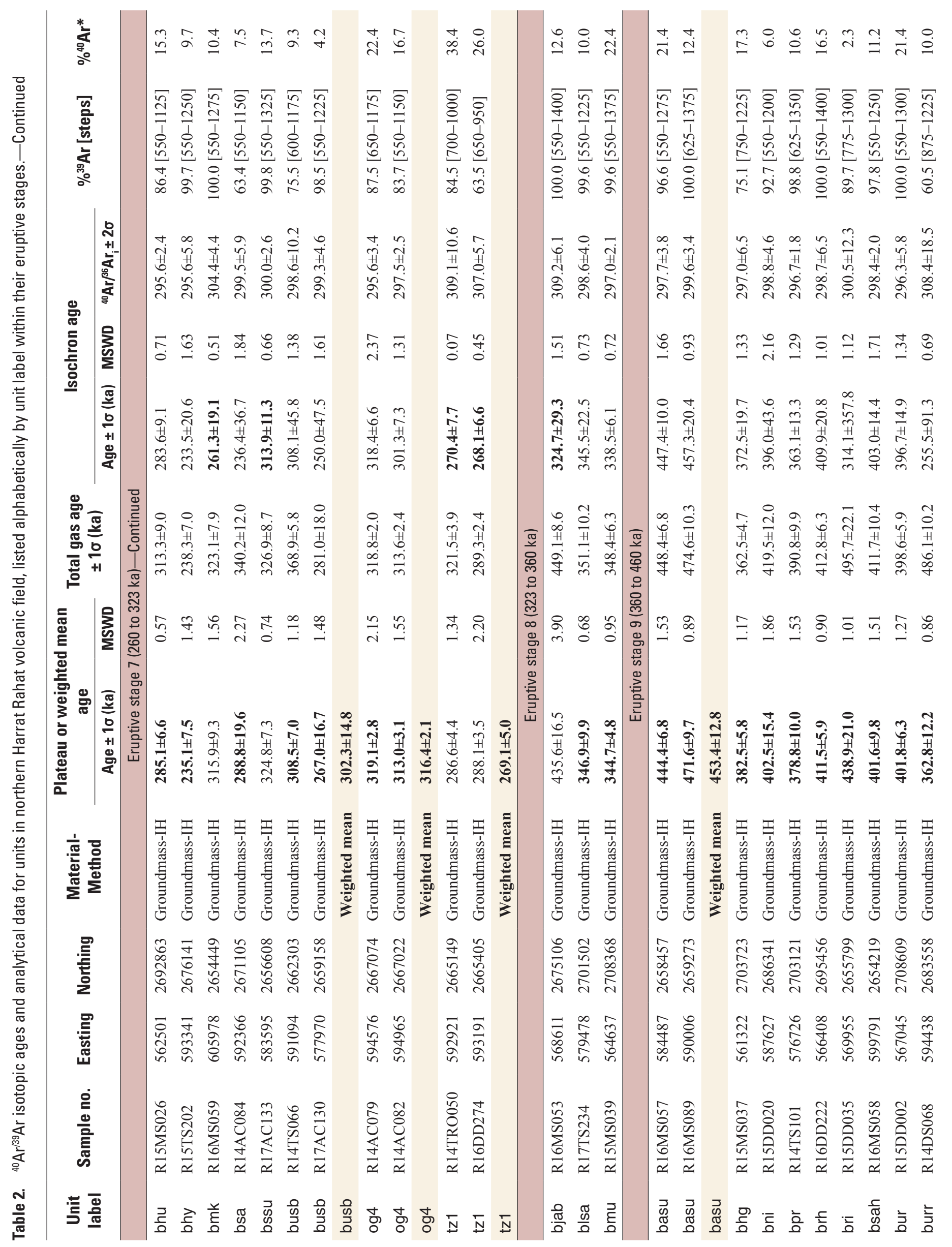




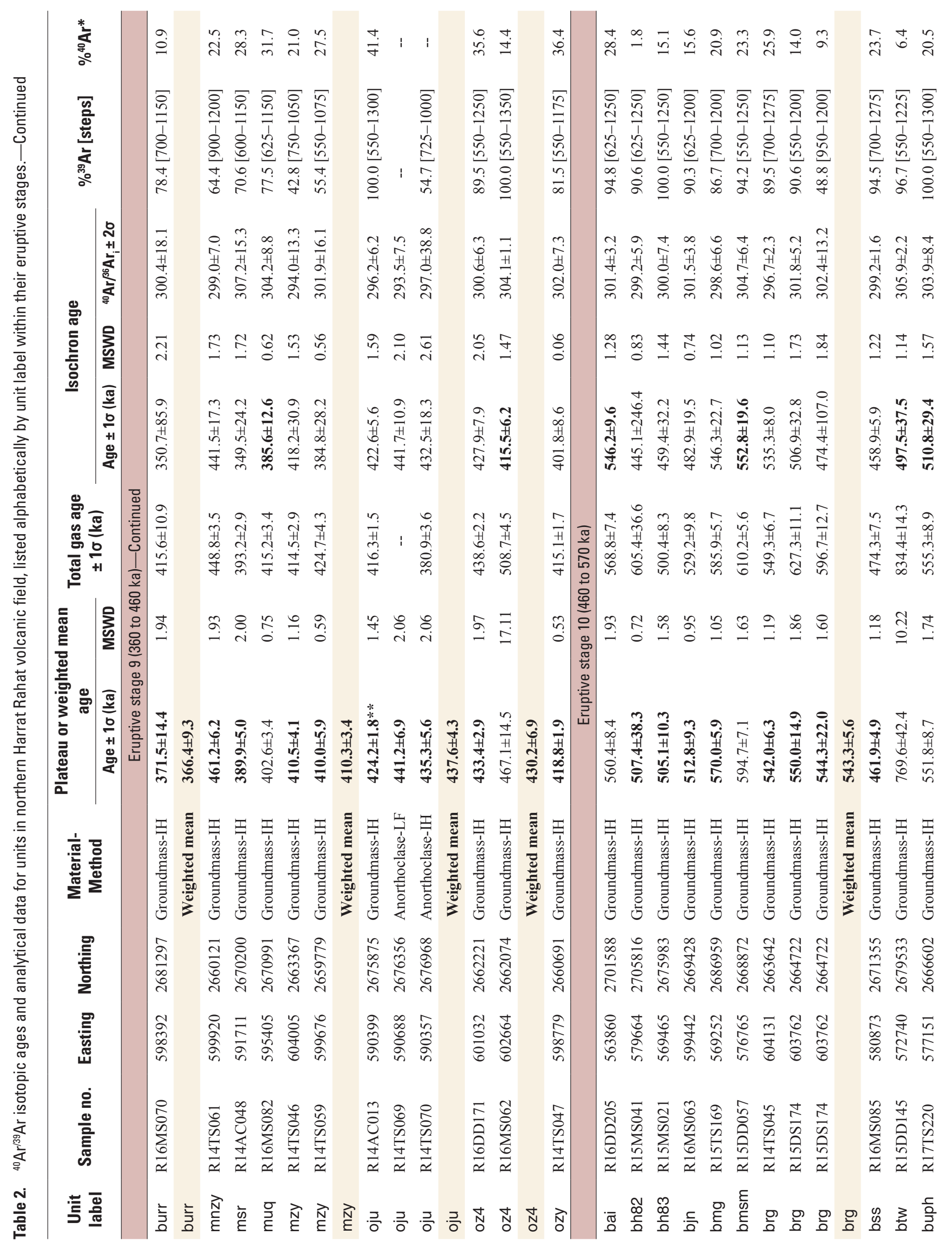




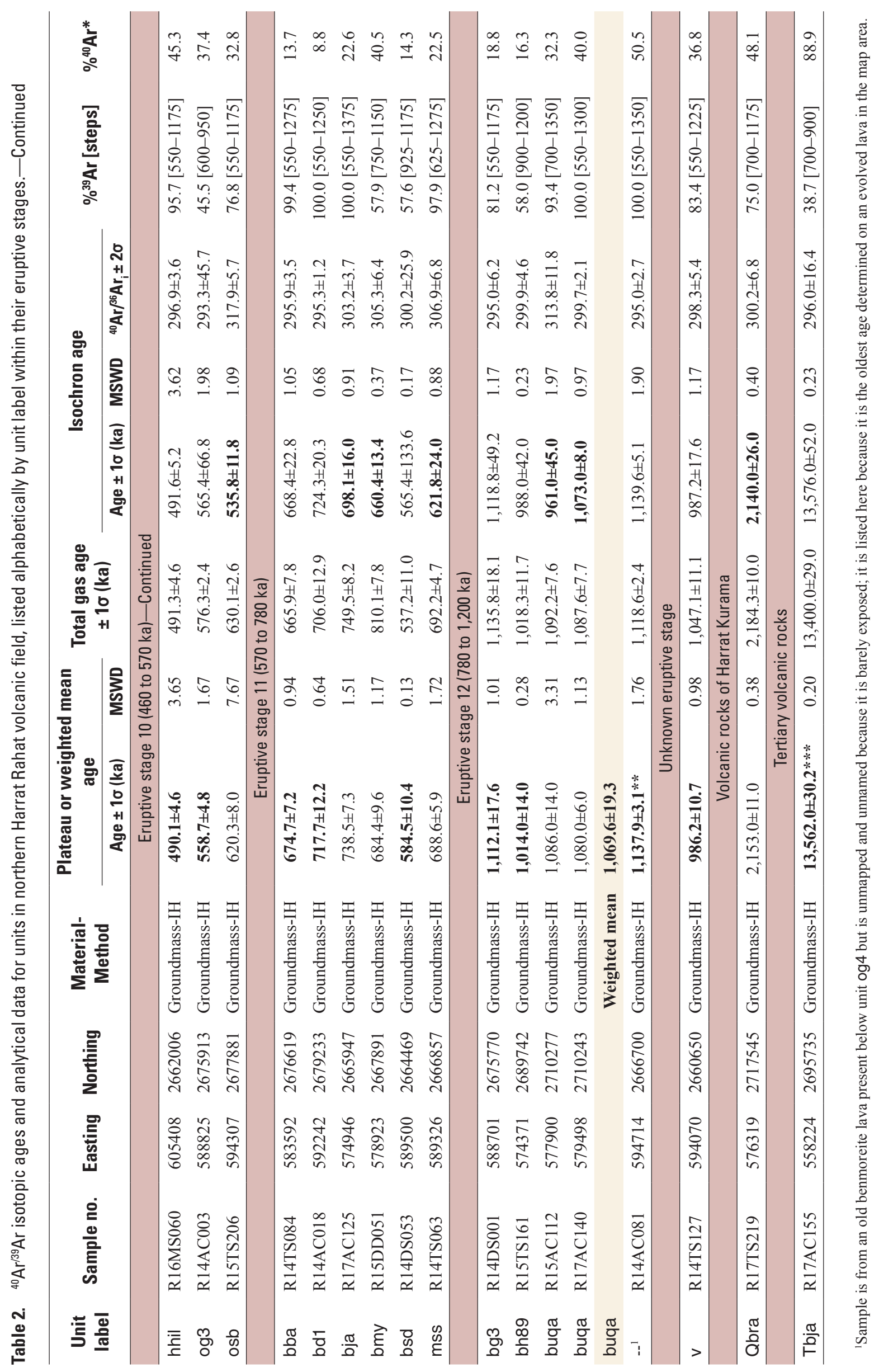


Table 3. ${ }^{36} \mathrm{Cl}$ cosmogenic surface-exposure ages and analytical data for units in northern Harrat Rahat volcanic field, listed alphabetically by unit label within their eruptive stages.

[Preferred ages shown in bold. Where available, weighted mean age is used as eruption age. Units bcef, bnof, and bsof make up the Five Fingers lava flows; weighted mean age of $24.4 \pm 1.3 \mathrm{ka}$ from five combined ages is used as eruption age. $\mathrm{All}{ }^{36} \mathrm{Cl}$ cosmogenic surface-exposure ages were calculated using CRONUScalc ${ }^{36} \mathrm{Cl}$ Exposure Age Calculator v2.0 (Marrero and others, 2016) and Lal-Stone time-independent scaling model (Lal, 1991; Stone, 2000). Bulk-rock Cl concentrations were measured by isotope dilution at Purdue Rare Isotope (PRIME) laboratory at Purdue University, West Lafayette, Ind. Major-oxide concentrations (as weight percent) were measured by X-ray fluorescence (XRF) spectrometry trace-element concentrations (as parts per million) were measured by inductively coupled plasma-atomic emission spectrometry (ICP-AES) and inductively coupled plasma-mass spectrometry (ICP-MS), following methods of Taggart (2002). Easting and northing values are in WGS1984 UTM Zone 37N coordinate system. Elevations are in meters above sea level (m ASL). Value of topographic shielding factor for all samples is 1]

\begin{tabular}{|c|c|c|c|c|c|c|c|c|c|c|c|}
\hline $\begin{array}{l}\text { Unit } \\
\text { label }\end{array}$ & Sample no. & Material & Easting & Northing & $\begin{array}{c}\text { Elevation } \\
\text { (m ASL) }\end{array}$ & $\begin{array}{l}\text { Thickness } \\
\text { (cm) }\end{array}$ & $\begin{array}{c}\text { Bulk } \\
\text { density } \\
\left(\mathrm{g} / \mathrm{cm}^{3}\right)\end{array}$ & $\begin{array}{c}{ }^{36} \mathrm{Cl} / \mathrm{Cl} \\
\left(10^{-15}\right) \pm 1 \sigma\end{array}$ & $\begin{array}{c}{ }^{36} \mathrm{Cl} \text { atoms } \\
\mathrm{g}^{-1}\left(10^{5}\right)\end{array}$ & $\begin{array}{l}{ }^{35} \mathrm{Cl} /{ }^{37} \mathrm{Cl} \\
\pm 1 \sigma\end{array}$ & $\begin{array}{l}{ }^{36} \mathrm{Cl} \text { ages } \\
\pm 1 \sigma \text { (ka) }\end{array}$ \\
\hline \multicolumn{12}{|c|}{ Eruptive stage 1 (0 to $11 \mathrm{ka}$ ) } \\
\hline bla & R14TS097 & Groundmass & 577423 & 2696155 & 814 & 2 & 2.49 & $6.3 \pm 0.7$ & $0.16 \pm 0.03$ & $4.11 \pm 0.04$ & $0.8 \pm 0.2$ \\
\hline \multicolumn{12}{|c|}{ Eruptive stage 2 (11 to $45 \mathrm{ka}$ ) } \\
\hline bcef & R15MS030 & Groundmass & 589383 & 2699479 & 820 & 4 & 1.87 & $129.5 \pm 5.5$ & $3.03 \pm 0.17$ & $4.45 \pm 0.06$ & $29.1 \pm 3.7$ \\
\hline bnof & R14TS019 & Groundmass & 586138 & 2697339 & 835 & 4 & 2.33 & $88.0 \pm 5.6$ & $2.76 \pm 0.18$ & $4.07 \pm 0.01$ & $22.0 \pm 3.3$ \\
\hline bsof & $\mathrm{R} 15 \mathrm{DS} 107^{(1)}$ & Plagioclase & 596998 & 2690714 & 820 & 1 & 2.68 & $204.9 \pm 9.1$ & $1.39 \pm 0.06$ & $28.47 \pm 0.75$ & $21.4 \pm 2.3$ \\
\hline bsof & R14TS009 & Groundmass & 589287 & 2687759 & 920 & 4 & 2.36 & $149.9 \pm 6.8$ & $2.43 \pm 0.13$ & $5.47 \pm 0.11$ & $26.4 \pm 2.9$ \\
\hline bsof & R15MS014 & Groundmass & 589900 & 2688412 & 914 & 5 & 2.33 & $153.4 \pm 7.8$ & $2.56 \pm 0.16$ & $5.36 \pm 0.11$ & $26.0 \pm 3.0$ \\
\hline \multicolumn{9}{|c|}{ bcef, bnof, and bsof } & \multicolumn{2}{|c|}{ Weighted mean } & $24.4 \pm 1.3$ \\
\hline bdu & R14AC099 & Groundmass & 550287 & 2700493 & 681 & 4 & 2.05 & $52.4 \pm 3.7$ & $1.43 \pm 0.11$ & $4.26 \pm 0.02$ & $13.3 \pm 1.9$ \\
\hline \multicolumn{12}{|c|}{ Eruptive stage 3 ( 45 to $70 \mathrm{ka}$ ) } \\
\hline bms & $\operatorname{R} 15 T S 189^{(2)}$ & Plagioclase & 578242 & 2677857 & 924 & 1 & 2.68 & $525.2 \pm 20.9$ & $3.55 \pm 0.14$ & $31.45 \pm 0.71$ & $56.5 \pm 6.7$ \\
\hline bms & R15MS004 & Groundmass & 580779 & 2680668 & 1,023 & 4 & 1.95 & $287.3 \pm 9.7$ & $8.94 \pm 0.46$ & $4.10 \pm 0.05$ & $66.0 \pm 11.0$ \\
\hline bms & & & & & & & & & \multicolumn{2}{|c|}{ Weighted mean } & $59.1 \pm 5.7$ \\
\hline han3 & R15MS006 & Groundmass & 578980 & 2682169 & 949 & 4 & 1.81 & $196.5 \pm 7.6$ & $8.39 \pm 0.54$ & $3.79 \pm 0.04$ & $51.0 \pm 9.0$ \\
\hline
\end{tabular}

${ }^{1}$ Age for sample R15DS107 was calculated using bulk-rock composition from sample R14TS009.

${ }^{2}$ Age for sample R15TS189 was calculated using bulk-rock composition from sample R15MS004. 


\begin{tabular}{|c|c|c|c|c|c|c|c|c|c|c|c|c|c|c|c|}
\hline $\mathrm{SiO}_{2}$ & $\mathrm{TiO}_{2}$ & $\mathrm{Al}_{2} \mathrm{O}_{3}$ & $\mathrm{Fe}_{2} \mathrm{O}_{3}$ & MnO & MgO & $\mathrm{CaO}$ & $\mathrm{Na}_{2} \mathrm{O}$ & $\mathrm{K}_{2} \mathrm{O}$ & $\mathrm{P}_{2} \mathrm{O}_{5}$ & LOI & Cl & Sm & Gd & $\mathbf{U}$ & Th \\
\hline \multicolumn{16}{|c|}{ Eruptive stage 1 ( 0 to $11 \mathrm{ka}$ ) } \\
\hline 46.9 & 3.07 & 16.9 & 13.8 & 0.21 & 5.75 & 8.29 & 4.03 & 0.97 & 0.89 & 0.44 & 145.5 & 7.0 & 7.24 & 0.49 & 1.50 \\
\hline \multicolumn{16}{|c|}{ Eruptive stage 2 ( 11 to $45 \mathrm{ka}$ ) } \\
\hline 47.0 & 3.75 & 17.4 & 12.6 & 0.14 & 4.68 & 9.50 & 3.36 & 0.73 & 0.29 & 0.60 & 101.0 & 5.0 & 5.30 & 0.48 & 1.20 \\
\hline 45.5 & 3.79 & 16.7 & 14.4 & 0.18 & 6.58 & 8.79 & 3.62 & 0.8 & 0.35 & 0.42 & 147.6 & 4.8 & 4.92 & 0.41 & 1.30 \\
\hline 52.5 & 0.09 & 30.3 & 0.44 & $<0.01$ & 0.07 & 12.0 & 4.37 & 0.21 & $<0.01$ & 0.28 & 1.2 & 0.2 & 0.13 & $<0.05$ & $<0.10$ \\
\hline 45.6 & 2.39 & 16.2 & 13.2 & 0.18 & 8.88 & 10.6 & 2.80 & 0.39 & 0.20 & 0.42 & 57.1 & 3.2 & 3.69 & 0.17 & 0.40 \\
\hline 46.2 & 2.94 & 17.2 & 12.9 & 0.17 & 6.23 & 10.8 & 3.06 & 0.56 & 0.22 & 0.33 & 60.0 & 4.2 & 4.57 & 0.28 & 0.80 \\
\hline 46.0 & 3.06 & 17.1 & 13.5 & 0.18 & 6.56 & 10.3 & 3.10 & 0.58 & 0.22 & 0.38 & 124.2 & 4.1 & 4.50 & 0.27 & 0.80 \\
\hline \multicolumn{16}{|c|}{ Eruptive stage 3 (45 to $70 \mathrm{ka}$ ) } \\
\hline 53.0 & 0.10 & 29.6 & 0.43 & $<0.01$ & 0.08 & 11.5 & 4.69 & 0.24 & 0.02 & 0.39 & 0.6 & 0.3 & 0.23 & 0.05 & 0.30 \\
\hline 46.5 & 3.56 & 17.9 & 13.9 & 0.20 & 4.83 & 8.17 & 3.96 & 0.84 & 0.49 & 0.29 & 144.1 & 3.6 & 3.80 & 0.33 & 1.00 \\
\hline 49.4 & 2.35 & 17.0 & 13.3 & 0.24 & 4.30 & 6.83 & 4.79 & 1.53 & 0.73 & 0.39 & 212.9 & 7.2 & 6.96 & 0.64 & 1.70 \\
\hline
\end{tabular}


Table 4. Paleomagnetic data for units in northern Harrat Rahat volcanic field, listed alphabetically by unit label within their eruptive stages.

[Easting and northing values are in WGS1984 UTM Zone 37N coordinate system. Treatment is nature of demagnetization procedure (Li, lines data; Pl, planes data; Mx, mixture of lines and planes data as alternating field; Th, mixture of lines and planes data as thermal). Inclination and declination values are in degrees. Platitude (in degrees north) and Plongitude (in degrees east) are coordinates of virtual geomagnetic pole calculated from mean direction. Unit mean values are in bold. Other abbreviations: N/No, number of cores used $(\mathrm{N})$ versus number of cores originally taken (No); a95, radius of 95 percent confidence limit about mean direction; $\mathrm{k}$, estimate of Fisher precision parameter; R, length of resultant vector; --, not applicable]

\begin{tabular}{|c|c|c|c|c|c|c|c|c|c|c|c|c|}
\hline $\begin{array}{l}\text { Unit } \\
\text { label }\end{array}$ & Sample no. & Easting & Northing & N/No & Treatment & Inclination & Declination & a95 & k & $\mathbf{R}$ & Platitude & Plongitude \\
\hline \multicolumn{13}{|c|}{ Eruptive stage 1 ( 0 to $11 \mathrm{ka}$ ) } \\
\hline bla & R14DC033 & 575865 & 2694831 & $8 / 8$ & $\mathrm{Li}$ & 30.2 & 11.3 & 3.5 & 256 & 7.9727 & 76.7 & 165.2 \\
\hline bla & R14DC034 & 578710 & 2692212 & $8 / 8$ & $\mathrm{Li}$ & 31.2 & 9.9 & 1.2 & 1,977 & 7.9965 & 78.1 & 166.9 \\
\hline bla & R14DC049 & 573396 & 2707253 & $8 / 8$ & $\mathrm{Li}$ & 30.2 & 9.1 & 1.9 & 855 & 7.9918 & 78.1 & 172.1 \\
\hline bla & Averages & 576047 & 2698719 & $3 / 3$ & -- & 30.5 & 10.1 & 1.7 & 5,227 & 2.9996 & 77.6 & 168.0 \\
\hline $\operatorname{trg}$ & R17DC018 & 599693 & 2665835 & $8 / 8$ & $\mathrm{Li}$ & 27.5 & 8.4 & 3.6 & 240 & 7.9709 & 77.6 & 178.7 \\
\hline \multicolumn{13}{|c|}{ Eruptive stage 2 (11 to $45 \mathrm{ka}$ ) } \\
\hline bcef & R14DC004 & 590252 & 2699069 & $7 / 8$ & $\mathrm{Li}$ & 38.4 & 0.1 & 2.4 & 661 & 6.9909 & 87.2 & 218.5 \\
\hline bcef & R14DC005 & 585622 & 2691643 & $8 / 8$ & $\mathrm{Li}$ & 37.4 & 1.6 & 2.7 & 434 & 7.9839 & 86.3 & 196.5 \\
\hline bcef & Averages & 588236 & 2695468 & $2 / 2$ & -- & 37.9 & 0.9 & 3.4 & 5,472 & 1.9998 & 86.8 & 205.4 \\
\hline bdu & R15DC012 & 550438 & 2700242 & $8 / 8$ & $\mathrm{Li}$ & 51.0 & 12.9 & 3.2 & 307 & 7.9772 & 76.5 & 93.9 \\
\hline bdu & $\mathrm{R} 15 \mathrm{DC} 013$ & 550305 & 2700519 & $8 / 8$ & $\mathrm{Mx}$ & 50.1 & 14.5 & 2.9 & 381 & 7.9816 & 75.6 & 99.5 \\
\hline bdu & R15DC014 & 550562 & 2699734 & $8 / 8$ & $\mathrm{Li}$ & $(44.4$ & 12.1) & 2.4 & 518 & 7.9865 & 78.1 & 118.2 \\
\hline bdu & Averages & 550387 & 2700375 & $2 / 3$ & -- & 50.6 & 13.7 & 3.0 & 7,121 & 2.9999 & 76.1 & 96.9 \\
\hline bdw & R15DC037 & 570525 & 2708047 & $8 / 9$ & $\mathrm{Li}$ & 41.1 & 14.7 & 2.1 & 713 & 7.9902 & 76.6 & 130.7 \\
\hline$b d w$ & R16DC018 & 572970 & 2703453 & $7 / 8$ & $\mathrm{Li}$ & 40.2 & 11.8 & 2.0 & 893 & 6.9933 & 79.1 & 135.4 \\
\hline$b d w$ & R16DC021 & 573563 & 2700533 & $7 / 8$ & $\mathrm{Li}$ & 36.9 & 11.2 & 4.0 & 233 & 6.9742 & 79.0 & 147.9 \\
\hline bdw & Averages & 571963 & 2704234 & $3 / 3$ & -- & 39.4 & 12.5 & 4.0 & 943 & 2.9979 & 78.3 & 137.6 \\
\hline bnof & R14DC007 & 584233 & 2693174 & $7 / 8$ & $\mathrm{Li}$ & 34.0 & 354.6 & 2.2 & 783 & 6.9923 & 82.4 & 262.1 \\
\hline bnof & R14DC008 & 586938 & 2695493 & $7 / 8$ & $\mathrm{Mx}$ & 36.8 & 359.4 & 2.7 & 545 & 6.9890 & 86.1 & 228.2 \\
\hline bnof & R14DC009 & 583685 & 2694887 & $8 / 8$ & $\mathrm{Li}$ & 34.4 & 354.8 & 1.6 & 1,147 & 7.9939 & 82.7 & 262.4 \\
\hline bnof & Averages & 585200 & 2694342 & $3 / 3$ & -- & 35.1 & 356.2 & 4.1 & 915 & 2.9978 & 83.9 & 255.5 \\
\hline bsof & R14DC001 & 589728 & 2688955 & $9 / 9$ & $\mathrm{Li}$ & 45.5 & 5.6 & 1.1 & 2,172 & 8.9963 & 84.3 & 101.0 \\
\hline bsof & R14DC002 & 593704 & 2695371 & $7 / 9$ & $\mathrm{Li}$ & 42.3 & 0.6 & 3.2 & 358 & 6.9833 & 89.5 & 116.5 \\
\hline bsof & R14DC003 & 600195 & 2698305 & $7 / 8$ & $\mathrm{Li}$ & 44.3 & 9.3 & 1.5 & 1,627 & 6.9963 & 81.4 & 117.0 \\
\hline bsof & R14DC006 & 598574 & 2692248 & $8 / 8$ & $\mathrm{Li}$ & 41.6 & 5.0 & 3.1 & 324 & 7.9784 & 85.4 & 113.6 \\
\hline bsof & Averages & 595351 & 2693300 & $4 / 4$ & -- & 43.5 & 5.1 & 3.6 & 660 & 3.9955 & 85.3 & 116.6 \\
\hline hkh & R14DC027 & 591298 & 2646645 & $8 / 8$ & $\mathrm{Li}$ & 68.7 & 335.4 & 3.1 & 327 & 7.9786 & 56.2 & 12.5 \\
\hline \multicolumn{13}{|c|}{ Eruptive stage 3 (45 to $70 \mathrm{ka}$ ) } \\
\hline bms & R14DC012 & 570332 & 2675581 & $7 / 9$ & Mx & 33.4 & 3.7 & 2.7 & 592 & 6.9899 & 83.1 & 188.9 \\
\hline bms & R14DC013 & 574775 & 2678537 & $7 / 8$ & $\mathrm{Li}$ & 37.2 & 7.5 & 3.9 & 242 & 6.9752 & 82.3 & 154.9 \\
\hline bms & R14DC039 & 567434 & 2682564 & $7 / 8$ & $\mathrm{Mx}$ & 37.7 & 357.8 & 3.2 & 360 & 6.9834 & 86.3 & 253.1 \\
\hline bms & R15DC044 & 560657 & 2683951 & $8 / 8$ & $\mathrm{Li}$ & 34.0 & 2.0 & 2.4 & 542 & 7.9871 & 84.1 & 200.7 \\
\hline bms & R14DC010 & 571810 & 2684424 & $8 / 8$ & $\mathrm{Li}$ & 32.8 & 4.2 & 2.0 & 763 & 7.9908 & 82.5 & 187.3 \\
\hline bms & Averages & 569036 & 2680966 & $5 / 5$ & - & 35.1 & 3.1 & 3.5 & 493 & 4.9919 & 84.3 & 189.0 \\
\hline han3 & R14DC011 & 582195 & 2684226 & $7 / 8$ & $\mathrm{Li}$ & 16.7 & 16.2 & 3.5 & 292 & 6.9794 & 67.9 & 172.6 \\
\hline han3 & R14DC042 & 566121 & 2694062 & $8 / 8$ & $\mathrm{Li}$ & 16.8 & 14.4 & 2.9 & 363 & 7.9807 & 69.1 & 176.2 \\
\hline han3 & Averages & 574071 & 2688743 & $2 / 2$ & -- & 16.8 & 15.3 & 3.8 & 4,406 & 1.9998 & 68.5 & 174.3 \\
\hline
\end{tabular}


Table 4. Paleomagnetic data for units in northern Harrat Rahat volcanic field, listed alphabetically by unit label within their eruptive stages.-Continued

\begin{tabular}{|c|c|c|c|c|c|c|c|c|c|c|c|c|}
\hline $\begin{array}{l}\text { Unit } \\
\text { label }\end{array}$ & Sample no. & Easting & Northing & N/No & Treatment & Inclination & Declination & a95 & $\mathbf{k}$ & $\mathbf{R}$ & Platitude & Plongitude \\
\hline \multicolumn{13}{|c|}{ Eruptive stage 4 (70 to $100 \mathrm{ka}$ ) } \\
\hline bsk & R14DC038 & 566343 & 2687852 & $5 / 9$ & $\mathrm{Mx}$ & 21.9 & 346.6 & 3.3 & 629 & 4.9936 & 71.9 & 266.5 \\
\hline bsk & R15DC042 & 562935 & 2689896 & $7 / 8$ & $\mathrm{Li}$ & 21.4 & 356.8 & 2.1 & 849 & 6.9929 & 76.5 & 233.0 \\
\hline bsk & R16DC046 & 566684 & 2684576 & $8 / 8$ & $\mathrm{Mx}$ & 26.6 & 355.4 & 2.1 & 700 & 7.9900 & 78.9 & 243.5 \\
\hline bsk & R17DC014 & 573836 & 2685243 & $5 / 8$ & $\mathrm{Pl}$ & 22.5 & $(0.7$ & 29.7) & 4 & -- & 77.4 & 216.6 \\
\hline bsk & Averages & 564944 & 2687591 & $3 / 4$ & -- & 23.4 & 352.9 & 8.9 & 192 & 2.9896 & 76.2 & 249.9 \\
\hline bsu & R15JR006 & 568576 & 2706564 & $6 / 8$ & $\mathrm{Mx}$ & 42.3 & 351.4 & 8.8 & 61 & 5.9183 & 82.2 & 311.4 \\
\hline bsu & $\mathrm{R} 15 \mathrm{DC} 024$ & 570137 & 2704579 & $8 / 8$ & $\mathrm{Li}$ & 41.4 & 354.1 & 1.6 & 1,268 & 7.9945 & 84.5 & 304.0 \\
\hline bsu & R15DC036 & 571542 & 2703268 & $8 / 8$ & $\mathrm{Li}$ & 36.8 & 356.4 & 2.4 & 542 & 7.9871 & 84.8 & 260.8 \\
\hline bsu & R16DC005 & 569657 & 2705186 & $8 / 8$ & $\mathrm{Mx}$ & 42.7 & 355.6 & 2.4 & 557 & 7.9874 & 86.0 & 315.0 \\
\hline bsu & R16DC019 & 572458 & 2702642 & $7 / 8$ & $\mathrm{Li}$ & 40.5 & 355.5 & 2.9 & 428 & 6.9860 & 85.7 & 293.0 \\
\hline bsu & R16DC020 & 572444 & 2701247 & $8 / 8$ & $\mathrm{Mx}$ & 39.5 & 354.5 & 2.1 & 721 & 7.9903 & 84.6 & 289.0 \\
\hline bsu & Averages & 570949 & 2704229 & $6 / 6$ & - & 40.5 & 354.6 & 2.1 & 1,011 & 5.9951 & 84.9 & 296.1 \\
\hline mh11 & R16DC035 & 573194 & 2693544 & $6 / 8$ & $\mathrm{Mx}$ & 34.4 & 358.7 & 7.7 & 89 & 5.9436 & 84.4 & $232 .^{\circ}$ \\
\hline mh11 & R16DC037 & 576429 & 2691800 & $4 / 8$ & $\mathrm{Mx}$ & 29.9 & 3.5 & 4.2 & 637 & 3.9953 & 81.1 & 197.5 \\
\hline mh11 & Averages & 575069 & 2692070 & $2 / 2$ & -- & 32.2 & 1.2 & 13.3 & 357 & 1.9972 & 83.0 & 210.6 \\
\hline mh11 & R15DC028 & 585871 & 2685809 & $8 / 8$ & $\mathrm{Mx}$ & 22.1 & 355.4 & 2.6 & 477 & 7.9853 & 76.5 & 239.5 \\
\hline mh11 & R15DC030 & 583975 & 2687049 & $8 / 8$ & $\mathrm{Mx}$ & 23.9 & 358.0 & 3.1 & 344 & 7.9797 & 78.1 & 229.3 \\
\hline mh11 & Averages & 584238 & 2685478 & $2 / 2$ & -- & 23.0 & 356.7 & 6.5 & 1,464 & 1.9993 & 77.3 & 234.7 \\
\hline tef & R17DC017 & 600521 & 2662364 & $8 / 8$ & $\mathrm{Mx}$ & 37.8 & 4.3 & 2.6 & 477 & 7.9853 & 85.1 & 165.0 \\
\hline $\operatorname{tg} 4$ & R17DC020 & 594953 & 2666345 & $8 / 8$ & $\mathrm{Mx}$ & 51.3 & 346.3 & 3.2 & 306 & 7.9771 & 75.6 & 346.1 \\
\hline $\operatorname{tg} 5$ & R17DC019 & 596693 & 2665991 & $8 / 8$ & $\mathrm{Li}$ & 50.4 & 339.4 & 3.0 & 345 & 7.9797 & 70.5 & 335.7 \\
\hline \multicolumn{13}{|c|}{ Eruptive stage 5 (100 to $180 \mathrm{ka}$ ) } \\
\hline bar & $\mathrm{R} 15 \mathrm{DC} 025$ & 590273 & 2681518 & $8 / 8$ & $\mathrm{Mx}$ & 52.6 & 0.3 & 3.2 & 316 & 7.9778 & 81.1 & 41.5 \\
\hline bdy & R14DC035 & 581219 & 2689923 & $8 / 8$ & $\mathrm{Li}$ & 25.9 & 8.2 & 2.6 & 454 & 7.9846 & 76.8 & 182.4 \\
\hline bdy & R16DC041 & 579387 & 2694541 & $8 / 8$ & $\mathrm{Mx}$ & 26.1 & 6.9 & 3.6 & 301 & 7.9768 & 77.6 & 187.0 \\
\hline bdy & Averages & 580141 & 2692098 & $2 / 2$ & - & 26.0 & 7.6 & 2.6 & 9,352 & 1.9999 & 77.2 & 184.6 \\
\hline bh10 & R15DC029 & 585138 & 2686081 & $8 / 8$ & $\mathrm{Mx}$ & 31.3 & 359.6 & 1.4 & 1,676 & 7.9958 & 82.6 & 222.8 \\
\hline bka & R14DC046 & 580468 & 2711201 & $8 / 8$ & $\mathrm{Mx}$ & 41.7 & 344.5 & 3.9 & 217 & 7.9678 & 75.9 & 311.0 \\
\hline bmat & R15DC033 & 571932 & 2698443 & $8 / 8$ & $\mathrm{Li}$ & 44.0 & 354.1 & 2.1 & 693 & 7.9899 & 84.5 & 325.4 \\
\hline bmat & R15DC035 & 570988 & 2700630 & $7 / 8$ & $\mathrm{Li}$ & 45.7 & 359.8 & 3.3 & 334 & 6.9821 & 87.3 & 35.9 \\
\hline bmat & R16DC038 & 575127 & 2694340 & $8 / 8$ & $\mathrm{Mx}$ & 41.2 & 351.4 & 3.2 & 329 & 7.9787 & 82.1 & 306.3 \\
\hline bmat & R16DC040 & 575082 & 2695226 & $8 / 8$ & $\mathrm{Li}$ & 45.7 & 358.1 & 2.4 & 544 & 7.9871 & 86.8 & 8.2 \\
\hline bmat & Averages & 573011 & 2697596 & $4 / 4$ & - & 44.2 & 355.8 & 3.9 & 545 & 3.9945 & 85.9 & 332.4 \\
\hline$b m z$ & R16DC031 & 572574 & 2691913 & $8 / 8$ & $\mathrm{Mx}$ & 46.9 & 9.7 & 3.3 & 288 & 7.9757 & 80.5 & 104.2 \\
\hline$b m z$ & R16DC033 & 572752 & 2696730 & $8 / 8$ & $\mathrm{Mx}$ & 46.8 & 9.1 & 3.0 & 362 & 7.9806 & 81.1 & 103.7 \\
\hline$b m z$ & Averages & 572622 & 2694272 & $2 / 2$ & - & 46.9 & 9.4 & 0.9 & 73,584 & 1.9999 & 80.8 & 103.9 \\
\hline bna & R14DC047 & 581560 & 2708118 & $8 / 8$ & $\mathrm{Mx}$ & 52.8 & 358.3 & 2.1 & 740 & 7.9905 & 81.0 & 30.7 \\
\hline bna & R15DC038 & 584668 & 2706807 & $8 / 8$ & $\mathrm{Mx}$ & 49.1 & 357.5 & 2.0 & 822 & 7.9915 & 84.1 & 18.5 \\
\hline bna & R16DC051 & 585033 & 2705248 & $8 / 8$ & $\mathrm{Li}$ & 48.1 & 356.9 & 1.8 & 960 & 7.9927 & 84.6 & 9.4 \\
\hline bna & Averages & 584113 & 2706516 & $3 / 3$ & -- & 50.0 & 357.5 & 3.8 & 1,037 & 2.9981 & 83.3 & 21.4 \\
\hline bns & R14DC026 & 577370 & 2647416 & $8 / 8$ & $\mathrm{Mx}$ & 37.1 & 24.0 & 3.3 & 337 & 7.9792 & 67.6 & 133.3 \\
\hline
\end{tabular}


Table 4. Paleomagnetic data for units in northern Harrat Rahat volcanic field, listed alphabetically by unit label within their eruptive stages.-Continued

\begin{tabular}{|c|c|c|c|c|c|c|c|c|c|c|c|c|}
\hline $\begin{array}{l}\text { Unit } \\
\text { label }\end{array}$ & Sample no. & Easting & Northing & N/No & Treatment & Inclination & Declination & a95 & $\mathbf{k}$ & $\mathbf{R}$ & Platitude & Plongitude \\
\hline \multicolumn{13}{|c|}{ Eruptive stage 5 (100 to $180 \mathrm{ka}$ )-Continued } \\
\hline bnu & R14DC043 & 567841 & 2695078 & $6 / 8$ & $\mathrm{Mx}$ & 33.5 & 357.7 & 3.5 & 371 & 5.9865 & 83.6 & 239.6 \\
\hline bnu & $\mathrm{R} 14 \mathrm{DC} 044$ & 569589 & 2696482 & $8 / 8$ & $\mathrm{Mx}$ & 39.0 & 352.1 & 3.3 & 302 & 7.9768 & 82.4 & 293.4 \\
\hline bnu & $\mathrm{R} 16 \mathrm{DC} 028$ & 569568 & 2694511 & $8 / 8$ & $\mathrm{Mx}$ & 31.9 & 359.2 & 2.3 & 598 & 7.9883 & 82.9 & 225.9 \\
\hline bnu & Averages & 568965 & 2695361 & $3 / 3$ & - & 34.8 & 356.5 & 7.3 & 285 & 2.9930 & 83.9 & 252.8 \\
\hline bra & R15JR007 & 567505 & 2703791 & $7 / 8$ & $\mathrm{Mx}$ & 44.9 & 356.5 & 2.9 & 386 & 7.9818 & 86.2 & 343.2 \\
\hline bra & R16DC008 & 571020 & 2704307 & $7 / 8$ & $\mathrm{Li}$ & 46.4 & 353.7 & 5.7 & 114 & 6.9473 & 83.5 & 341.0 \\
\hline bra & R16DC034 & 572342 & 2695521 & $8 / 8$ & Mx & 37.2 & 359.2 & 2.4 & 653 & 7.9893 & 86.3 & 231.5 \\
\hline bra & Averages & 569952 & 2700902 & $3 / 3$ & -- & 42.9 & 356.6 & 8.1 & 231 & 2.9913 & 86.9 & 319.0 \\
\hline bsas & R15DC021 & 599006 & 2676947 & $8 / 8$ & $\mathrm{Mx}$ & 34.7 & 358.9 & 3.3 & 293 & 7.9761 & 84.8 & 231.5 \\
\hline bsb & R16DC032 & 573197 & 2691108 & $8 / 8$ & $\mathrm{Mx}$ & 30.9 & 349.3 & 3.6 & 275 & 7.9746 & 77.4 & 274.3 \\
\hline bsi & R14DC037 & 587286 & 2683426 & $7 / 8$ & $\mathrm{Li}$ & 31.5 & 0.0 & 3.4 & 320 & 6.9813 & 82.8 & 220.9 \\
\hline bsi & $\mathrm{R} 15 \mathrm{DC} 027$ & 586875 & 2684209 & $8 / 8$ & $\mathrm{Li}$ & 31.2 & 359.0 & 1.7 & 1,065 & 7.9934 & 82.5 & 227.2 \\
\hline bsi & Averages & 587297 & 2683282 & $2 / 2$ & -- & 31.4 & 359.5 & 2.0 & 16,009 & 1.9999 & 82.7 & 223.6 \\
\hline bsq & R16DC043 & 570000 & 2689209 & $8 / 8$ & $\mathrm{Mx}$ & 44.1 & 352.2 & 4.9 & 148 & 7.9528 & 82.8 & 323.6 \\
\hline bsy & $\mathrm{R} 15 \mathrm{DC} 046$ & 560120 & 2678944 & $4 / 8$ & $\mathrm{Mx}$ & 29.7 & 355.7 & 5.2 & 347 & 3.9913 & 80.8 & 246.3 \\
\hline bun & R16DC001 & 559356 & 2693977 & $6 / 8$ & Mx & 58.5 & 349.9 & 3.0 & 553 & 5.9910 & 72.9 & 12.1 \\
\hline bun & R16DC002 & 556180 & 2694385 & $8 / 8$ & $\mathrm{Li}$ & 57.5 & 346.2 & 2.4 & 516 & 7.9864 & 71.9 & 2.5 \\
\hline bun & Averages & 557814 & 2694203 & $2 / 2$ & -- & $\mathbf{5 8 . 0}$ & 348.0 & 4.8 & 2,711 & 1.9996 & 72.5 & 7.1 \\
\hline bwar & R15DC026 & 588999 & 2682174 & $8 / 8$ & $\mathrm{Li}$ & 37.9 & 6.9 & 3.6 & 233 & 7.9699 & 83.0 & 156.3 \\
\hline han1 & $\mathrm{R} 15 \mathrm{DC} 052$ & 569857 & 2699705 & $7 / 8$ & $\mathrm{Li}$ & 50.2 & 341.6 & 1.8 & 1,184 & 6.9949 & 72.4 & 335.6 \\
\hline md1 & $\mathrm{R} 14 \mathrm{DC} 015$ & 591676 & 2679611 & $8 / 8$ & $\mathrm{Li}$ & 33.9 & 2.0 & 3.7 & 226 & 7.9690 & 84.1 & 200.9 \\
\hline $\mathrm{mmk}$ & R14DC030 & 603966 & 2658280 & $7 / 8$ & $\mathrm{Li}$ & 41.3 & 12.0 & 3.9 & 238 & 6.9748 & 79.0 & 129.3 \\
\hline $\mathrm{mz2}$ & $\mathrm{R} 15 \mathrm{DC} 017$ & 605482 & 2670638 & $6 / 8$ & $\mathrm{Mx}$ & 25.2 & 37.5 & 5.4 & 193 & 5.9741 & 53.0 & 140.3 \\
\hline $\mathrm{mz2}$ & R16DC053 & 589991 & 2663390 & $6 / 8$ & Mx & 39.2 & 22.5 & 11.0 & 44 & 5.8857 & 69.2 & 130.6 \\
\hline $\mathrm{mz2}$ & R14DC032 & 604185 & 2668668 & $7 / 8$ & $\mathrm{Mx}$ & 44.7 & 4.3 & 5.6 & 121 & 6.9503 & 85.5 & 99.6 \\
\hline mz2 & R16DC055 & 605611 & 2669631 & $7 / 8$ & $\mathrm{Li}$ & 47.3 & 355.1 & 4.6 & 175 & 6.9657 & 83.9 & 355.2 \\
\hline $\mathrm{mz2}$ & R16DC054 & 598319 & 2667597 & $5 / 8$ & $\mathrm{Mx}$ & 43.6 & 9.6 & 4.7 & 418 & 4.9904 & 81.2 & 119.2 \\
\hline $\mathrm{mz2}$ & R16DC052 & 589619 & 2666000 & $5 / 8$ & Mx & 49.8 & 359.3 & 5.1 & 236 & 4.9831 & 83.5 & 34.6 \\
\hline $\mathrm{mz2}$ & Averages & 601620 & 2667875 & $4 / 6$ & - & 46.5 & 2.3 & 5.9 & 248 & 3.9879 & 85.8 & 68.9 \\
\hline oba & R14DC018 & 584019 & 2676264 & $6 / 8$ & $\mathrm{Pl}$ & 47.8 & 43.8 & 2.2 & 675 & 7.1584 & 50.8 & 113.2 \\
\hline \multicolumn{13}{|c|}{ Eruptive stage 6 (180 to $260 \mathrm{ka}$ ) } \\
\hline bag & R17DC001 & 586413 & 2693419 & $7 / 8$ & Mx & 40.9 & 19.4 & 2.9 & 431 & 6.9861 & 72.3 & 128.9 \\
\hline bag & R17DC002 & 588429 & 2695458 & $8 / 8$ & Mx & 40.7 & 19.8 & 6.7 & 80 & 7.9119 & 71.9 & 129.3 \\
\hline bag & $\mathrm{R} 17 \mathrm{DC} 003$ & 589850 & 2693684 & $6 / 8$ & Mx & 41.5 & 23.2 & 2.4 & 858 & 5.9942 & 68.8 & 126.4 \\
\hline bag & Averages & 588243 & 2694361 & $3 / 3$ & -- & 41.1 & 20.8 & 2.5 & 2,483 & 2.9992 & 71.0 & 128.1 \\
\hline bbd & $\mathrm{R} 16 \mathrm{DC} 014$ & 564534 & 2699492 & $7 / 8$ & Mx & 26.5 & 357.7 & 3.7 & 322 & 6.9814 & 79.4 & 231.8 \\
\hline bbd & R16DC016 & 566916 & 2697587 & $7 / 8$ & $\mathrm{Mx}$ & 25.8 & 9.1 & 3.2 & 423 & 6.9858 & 76.2 & 179.5 \\
\hline bbd & R16DC017 & 564592 & 2697942 & $5 / 8$ & $\mathrm{Mx}$ & 27.8 & 10.1 & 2.8 & 768 & 4.9948 & 76.5 & 173.2 \\
\hline bbd & Averages & 564897 & 2697777 & $2 / 3$ & -- & 26.8 & 9.6 & 4.8 & 2,738 & 2.9996 & 76.4 & 176.4 \\
\hline bhy & R14DC016 & 595410 & 2673944 & $8 / 8$ & $\mathrm{Li}$ & 29.5 & 357.3 & 3.5 & 256 & 7.9727 & 81.3 & 237.0 \\
\hline bjs & R14DC041 & 564322 & 2692725 & $8 / 8$ & Mx & 48.5 & 331.8 & 3.3 & 318 & 7.9780 & 64.4 & 327.4 \\
\hline
\end{tabular}


Table 4. Paleomagnetic data for units in northern Harrat Rahat volcanic field, listed alphabetically by unit label within their eruptive stages.-Continued

\begin{tabular}{|c|c|c|c|c|c|c|c|c|c|c|c|c|}
\hline $\begin{array}{l}\text { Unit } \\
\text { label }\end{array}$ & Sample no. & Easting & Northing & N/No & Treatment & Inclination & Declination & a95 & $\mathbf{k}$ & $\mathbf{R}$ & Platitude & Plongitude \\
\hline \multicolumn{13}{|c|}{ Eruptive stage 6 ( 180 to $260 \mathrm{ka}$ ) - Continued } \\
\hline bli & R14DC036 & 583441 & 2688164 & $8 / 8$ & $\mathrm{Mx}$ & 42.4 & 330.6 & 4.5 & 183 & 7.9618 & 63.3 & 316.5 \\
\hline blqa & R14DC045 & 580799 & 2711701 & $7 / 8$ & $\mathrm{Li}$ & 31.1 & 359.1 & 3.5 & 300 & 6.9800 & 82.2 & 226.2 \\
\hline blsl & R17DC022 & 597832 & 2688068 & $8 / 8$ & $\mathrm{Mx}$ & 30.5 & 7.7 & 4.2 & 194 & 7.9639 & 79.3 & 176.1 \\
\hline bqg & R14DC040 & 568498 & 2678783 & $8 / 8$ & $\mathrm{Mx}$ & 40.7 & 18.0 & 3.3 & 296 & 7.9764 & 73.5 & 129.3 \\
\hline bqg & R15DC048 & 568665 & 2677931 & $8 / 8$ & $\mathrm{Mx}$ & 46.0 & 8.0 & 4.1 & 193 & 7.9638 & 82.1 & 104.3 \\
\hline bqg & Averages & 568539 & 2678750 & $2 / 2$ & - & 43.5 & 13.2 & 19.7 & 163 & 1.9939 & 78.0 & 121.5 \\
\hline bru & R15DC034 & 570341 & 2698235 & $8 / 8$ & $\mathrm{Mx}$ & 46.7 & 329.2 & 3.6 & 270 & 7.9741 & 62.2 & 323.8 \\
\hline bru & R16DC012 & 568530 & 2701371 & $6 / 8$ & Mx & 49.0 & 336.3 & 4.2 & 324 & 5.9846 & 68.3 & 329.5 \\
\hline bru & R16DC015 & 567440 & 2700458 & $8 / 9$ & $\mathrm{Mx}$ & 43.0 & 331.9 & 2.0 & 1,004 & 7.9930 & 64.5 & 316.9 \\
\hline bru & Averages & 568944 & 2699790 & $3 / 3$ & - & 46.3 & 332.4 & 5.9 & 435 & 2.9954 & 65.0 & 323.0 \\
\hline bsf & R15DC050 & 569863 & 2671747 & $8 / 8$ & $\mathrm{Li}$ & 59.7 & 349.8 & 3.7 & 223 & 7.9687 & 71.5 & 14.6 \\
\hline bsh & R15DC008 & 563255 & 2697637 & $8 / 8$ & $\mathrm{Mx}$ & 22.4 & 26.4 & 2.0 & 880 & 7.9920 & 61.9 & 151.9 \\
\hline bsh & R15DC031 & 564337 & 2698395 & $7 / 8$ & $\mathrm{Li}$ & 22.7 & 26.1 & 3.2 & 349 & 6.9828 & 62.3 & 151.9 \\
\hline bsh & R16DC027 & 567367 & 2694489 & $9 / 9$ & $\mathrm{Mx}$ & 28.9 & 19.4 & 4.8 & 125 & 8.9362 & 69.7 & 152.2 \\
\hline bsh & R16DC030 & 569765 & 2691589 & $6 / 8$ & $\mathrm{Mx}$ & 28.7 & 31.5 & 10.7 & 56 & 5.9104 & 59.1 & 140.8 \\
\hline bsh & R16DC029 & 570473 & 2693973 & $7 / 8$ & $\mathrm{Li}$ & 17.9 & 22.7 & 2.8 & 468 & 6.9872 & 63.6 & 160.9 \\
\hline bsh & R16DC044 & 570199 & 2690007 & $7 / 8$ & $\mathrm{Mx}$ & 45.6 & 4.7 & 2.3 & 824 & 6.9927 & 85.0 & 95.9 \\
\hline bsh & Averages & 566937 & 2695351 & $5 / 6$ & - & 24.2 & 25.2 & 5.9 & 171 & 4.9767 & 63.5 & 151.3 \\
\hline $\mathrm{hma}$ & R14DC017 & 583251 & 2697951 & $7 / 8$ & $\mathrm{Li}$ & 15.9 & 356.1 & 4.5 & 185 & 6.9676 & 73.3 & 233.5 \\
\hline $\mathrm{mmu}$ & R14DC019 & 589403 & 2672820 & $7 / 8$ & $\mathrm{Mx}$ & 37.6 & 2.9 & 3.0 & 497 & 6.9879 & 85.9 & 178.6 \\
\hline \multicolumn{13}{|c|}{ Eruptive stage 7 (260 to $323 \mathrm{ka}$ ) } \\
\hline bau & R16DC042 & 559400 & 2688518 & $6 / 8$ & Pl & 47.0 & 23.2 & 5.3 & 116 & -- & 68.9 & 113.9 \\
\hline bd3 & R15DC018 & 601672 & 2671961 & $8 / 8$ & $\mathrm{Mx}$ & 47.0 & 5.4 & 3.6 & 258 & 7.9729 & 83.7 & 89.0 \\
\hline bh86 & $\mathrm{R} 15 \mathrm{DC} 047$ & 566784 & 2665432 & $8 / 8$ & $\mathrm{Li}$ & 32.0 & 344.6 & 2.0 & 758 & 7.9908 & 74.1 & 287.5 \\
\hline bhu & R15DC007 & 561046 & 2699532 & $8 / 8$ & $\mathrm{Mx}$ & 44.8 & 18.6 & 1.9 & 943 & 7.9926 & 73.1 & 118.9 \\
\hline bhu & R15DC009 & 561258 & 2692845 & $8 / 8$ & $\mathrm{Li}$ & 44.7 & 25.0 & 3.3 & 281 & 7.9751 & 67.4 & 119.3 \\
\hline bhu & R15DC010 & 560948 & 2694261 & $8 / 8$ & $\mathrm{Li}$ & 45.9 & 25.7 & 2.8 & 391 & 7.9821 & 66.8 & 116.8 \\
\hline bhu & R15DC011 & 561334 & 2696455 & $7 / 8$ & $\mathrm{Li}$ & 44.0 & 24.9 & 2.0 & 927 & 6.9935 & 67.4 & 120.8 \\
\hline bhu & R15DC015 & 561697 & 2701406 & $8 / 8$ & $\mathrm{Mx}$ & 43.3 & 26.0 & 3.2 & 314 & 7.9777 & 66.4 & 122.2 \\
\hline bhu & Averages & 561253 & 2696432 & $5 / 5$ & -- & 44.6 & 24.1 & 2.3 & 1,146 & 4.9965 & 68.2 & 119.6 \\
\hline \multicolumn{13}{|c|}{ Eruptive stage 8 ( 323 to $360 \mathrm{ka}$ ) } \\
\hline blsa & R15DC041 & 578545 & 2705321 & $8 / 8$ & $\mathrm{Li}$ & 41.7 & 18.4 & 2.0 & 779 & 7.9910 & 73.2 & 127.5 \\
\hline blsa & R16DC047 & 576831 & 2707504 & $8 / 8$ & $\mathrm{Mx}$ & 31.7 & 10.8 & 3.8 & 255 & 7.9726 & 77.5 & 163.7 \\
\hline blsa & R16DC048 & 578081 & 2706824 & $5 / 8$ & $\mathrm{Mx}$ & 21.6 & 49.8 & 5.1 & 237 & 4.9831 & 41.1 & 136.3 \\
\hline blsa & R17DC015 & 579459 & 2701517 & $8 / 8$ & $\mathrm{Pl}$ & 46.5 & 347.3 & 5.1 & 94 & -- & 78.1 & 328.9 \\
\hline bmu & R15JR004 & 562948 & 2707224 & $8 / 8$ & $\mathrm{Mx}$ & 47.9 & 350.6 & 1.2 & 2,272 & 7.9969 & 80.5 & 339.8 \\
\hline bmu & R15JR005 & 566034 & 2706142 & $7 / 8$ & $\mathrm{Mx}$ & 46.3 & 357.1 & 4.9 & 164 & 6.9633 & 85.9 & 0.7 \\
\hline bmu & R16DC039 & 575041 & 2693421 & $8 / 8$ & $\mathrm{Mx}$ & 48.6 & 347.1 & 2.7 & 432 & 7.9838 & 77.4 & 336.9 \\
\hline bmu & Averages & 567919 & 2701999 & $3 / 3$ & - & 47.7 & 351.7 & 5.5 & 499 & 2.9960 & 81.4 & 341.7 \\
\hline \multicolumn{13}{|c|}{ Eruptive stage 9 (360 to $460 \mathrm{ka}$ ) } \\
\hline bhg & R15DC001 & 559091 & 2706421 & $8 / 8$ & $\mathrm{Mx}$ & $(44.7$ & $352.3)$ & 2.6 & 540 & 7.9870 & 82.8 & 326.2 \\
\hline
\end{tabular}


Table 4. Paleomagnetic data for units in northern Harrat Rahat volcanic field, listed alphabetically by unit label within their eruptive stages.-Continued

\begin{tabular}{|c|c|c|c|c|c|c|c|c|c|c|c|c|}
\hline $\begin{array}{l}\text { Unit } \\
\text { label }\end{array}$ & Sample no. & Easting & Northing & N/No & Treatment & Inclination & Declination & a95 & $\mathbf{k}$ & $\mathbf{R}$ & Platitude & Plongitude \\
\hline \multicolumn{13}{|c|}{ Eruptive stage 9 ( 360 to $460 \mathrm{ka}$ ) - Continued } \\
\hline bhg & R15DC002 & 558440 & 2706972 & $8 / 8$ & $\mathrm{Li}$ & 54.7 & 342.3 & 1.2 & 2,303 & 7.9970 & 71.3 & 348.6 \\
\hline bhg & $\mathrm{R} 15 \mathrm{DC} 003$ & 560889 & 2702974 & $7 / 8$ & $\mathrm{Mx}$ & 55.3 & 352.0 & 1.9 & 1,105 & 6.9946 & 76.7 & 10.3 \\
\hline bhg & $\mathrm{R} 15 \mathrm{DC} 004$ & 560873 & 2704392 & $8 / 8$ & $\mathrm{Mx}$ & 54.8 & 343.5 & 2.4 & 558 & 7.9874 & 72.1 & 350.8 \\
\hline bhg & $\mathrm{R} 15 \mathrm{DC} 005$ & 561890 & 2703676 & $8 / 8$ & $\mathrm{Mx}$ & 53.3 & 348.2 & 2.3 & 583 & 7.9880 & 76.1 & 354.8 \\
\hline bhg & R15DC006 & 559564 & 2704895 & $8 / 8$ & $\mathrm{Mx}$ & 58.0 & 346.7 & 3.2 & 322 & 7.9782 & 71.9 & 4.3 \\
\hline bhg & $\mathrm{R} 15 \mathrm{DC} 051$ & 558390 & 2701912 & $7 / 8$ & $\mathrm{Li}$ & 56.2 & 349.7 & 1.4 & 1,936 & 6.9969 & 74.8 & 6.4 \\
\hline bhg & Averages & 559800 & 2704177 & $6 / 7$ & -- & 55.4 & 347.1 & 2.2 & 943 & 5.9947 & 74.0 & 358.5 \\
\hline bni & R14DC014 & 586694 & 2685637 & $8 / 8$ & $\mathrm{Mx}$ & 26.1 & 14.1 & 4.2 & 198 & 7.9647 & 73.0 & 165.6 \\
\hline bpr & R16DC050 & 576587 & 2703937 & $8 / 8$ & $\mathrm{Li}$ & 53.7 & 353.5 & 1.7 & 1,102 & 7.9937 & 78.7 & 11.2 \\
\hline bqr & $\mathrm{R} 15 \mathrm{DC} 032$ & 566169 & 2699079 & $7 / 8$ & $\mathrm{Li}$ & 44.3 & 356.8 & 2.0 & 945 & 6.9937 & 86.7 & 338.8 \\
\hline bqr & R16DC011 & 565968 & 2702953 & $7 / 8$ & $\mathrm{Mx}$ & 46.4 & 352.7 & 3.0 & 405 & 6.9852 & 82.7 & 337.7 \\
\hline bqr & R16DC010 & 565120 & 2702241 & $6 / 8$ & Mx & $(68.5$ & 50.4) & 9.6 & 70 & 5.9284 & 43.2 & 80.5 \\
\hline bqr & R16DC013 & 565399 & 2698986 & $7 / 8$ & $\mathrm{Mx}$ & $(84.3$ & $60.4)$ & 13.1 & 25 & 6.7612 & 29.6 & 50.9 \\
\hline bqr & Averages & 565998 & 2700883 & $2 / 4$ & -- & 45.4 & 354.8 & 7.8 & 1,033 & 1.9990 & 84.7 & 338.2 \\
\hline brh & R16DC022 & 566460 & 2695448 & $7 / 8$ & $\mathrm{Mx}$ & -13.8 & 56.7 & 5.9 & 123 & 6.9511 & 26.5 & 151.7 \\
\hline brh & R16DC025 & 564475 & 2696956 & $8 / 8$ & Mx & 1.1 & 351.4 & 2.9 & 393 & 7.9822 & 64.8 & 240.2 \\
\hline bur & R15JR001 & 565619 & 2708178 & $8 / 8$ & $\mathrm{Mx}$ & 36.0 & 352.1 & 1.9 & 855 & 7.9918 & 81.4 & 279.5 \\
\hline bur & R15JR002 & 566984 & 2706701 & $8 / 8$ & Mx & 37.2 & 356.4 & 2.5 & 511 & 7.9863 & 85.0 & 262.4 \\
\hline bur & R15JR003 & 567036 & 2708594 & $8 / 8$ & $\mathrm{Pl}$ & 41.3 & 351.7 & 16.0 & 10 & -- & 82.4 & 305.5 \\
\hline bur & Averages & 566879 & 2707531 & $3 / 3$ & -- & 38.2 & 353.4 & 5.3 & 550 & 2.9964 & 83.2 & 284.5 \\
\hline burr & $\mathrm{R} 15 \mathrm{DC} 022$ & 592117 & 2680533 & $8 / 8$ & $\mathrm{Mx}$ & 41.0 & 3.8 & 4.4 & 182 & 7.9615 & 86.5 & 141.2 \\
\hline burr & $\mathrm{R} 15 \mathrm{DC} 023$ & 590843 & 2681211 & $7 / 8$ & $\mathrm{Li}$ & 39.5 & 3.1 & 3.1 & 1,344 & 6.9955 & 86.6 & 162.2 \\
\hline burr & R17DC021 & 598235 & 2681183 & $8 / 8$ & $\mathrm{Li}$ & 40.9 & 354.9 & 2.2 & 625 & 7.9888 & 85.3 & 301.0 \\
\hline burr & Averages & 593403 & 2681106 & $3 / 3$ & -- & 40.5 & 0.6 & 5.9 & 444 & 2.9955 & 88.8 & 192.3 \\
\hline hsb & $\mathrm{R} 15 \mathrm{DC} 020$ & 600192 & 2675771 & $7 / 8$ & Mx & 55.6 & 118.1 & 5.3 & 173 & 6.9653 & -6.1 & 85.7 \\
\hline muq & R15DC019 & 600551 & 2673891 & $8 / 8$ & $\mathrm{Li}$ & 39.9 & 25.6 & 3.2 & 311 & 7.9775 & 66.6 & 128.4 \\
\hline $\mathrm{mz3}$ & R14DC031 & 603273 & 2665572 & $7 / 8$ & Mx & 51.9 & 19.8 & 2.3 & 732 & 6.9918 & 70.7 & 99.7 \\
\hline $\mathrm{mz} 6$ & R14DC024 & 598784 & 2660657 & $6 / 8$ & $\mathrm{Li}$ & 53.8 & 18.2 & 3.2 & 446 & 5.9888 & 71.1 & 92.7 \\
\hline oz5 & $\mathrm{R} 14 \mathrm{DC} 023$ & 598753 & 2660701 & $7 / 8$ & Th & 51.7 & 1.9 & 3.3 & 354 & 6.9831 & 81.6 & 51.0 \\
\hline ozy & R14DC022 & 598783 & 2660724 & $8 / 8$ & $\mathrm{Li}$ & 8.8 & 351.2 & 2.7 & 429 & 7.9837 & 68.7 & 244.6 \\
\hline tz6 & R14DC021 & 597645 & 2660583 & 9/9 & $\mathrm{Li}$ & 49.3 & 16.2 & 2.8 & 342 & 8.9766 & 74.4 & 103.3 \\
\hline \multicolumn{13}{|c|}{ Eruptive stage 10 (460 to $570 \mathrm{ka}$ ) } \\
\hline bai & $\mathrm{R} 16 \mathrm{DC} 026$ & 568913 & 2693710 & $8 / 8$ & $\mathrm{Mx}$ & 43.4 & 350.8 & 1.6 & 1,271 & 7.9945 & 81.6 & 318.1 \\
\hline bai & R16DC009 & 564302 & 2701639 & $8 / 8$ & $\mathrm{Mx}$ & 39.8 & 349.3 & 1.5 & 1,350 & 7.9948 & 80.0 & 301.4 \\
\hline bai & $\mathrm{R} 16 \mathrm{DC} 024$ & 565066 & 2696361 & $6 / 8$ & $\mathrm{Mx}$ & 39.7 & 352.2 & 6.6 & 118 & 5.9577 & 82.6 & 296.8 \\
\hline bai & Averages & 565912 & 2697560 & $3 / 3$ & -- & 41.0 & 350.8 & 3.6 & 1,159 & 2.9983 & 81.5 & 305.3 \\
\hline bfa & R17DC008 & 576759 & 2674030 & $7 / 8$ & $\mathrm{Mx}$ & -20.8 & 5.7 & 5.1 & 162 & 6.9630 & 54.6 & 210.1 \\
\hline bh82 & R14DC048 & 579963 & 2707378 & $8 / 8$ & $\mathrm{Li}$ & 37.2 & 2.2 & 2.4 & 523 & 7.9866 & 85.8 & 190.8 \\
\hline bh82 & R15DC039 & 582495 & 2705897 & $8 / 8$ & $\mathrm{Mx}$ & 39.4 & 4.5 & 2.3 & 673 & 7.9896 & 85.4 & 156.3 \\
\hline bh82 & $\mathrm{R} 15 \mathrm{DC} 040$ & 580765 & 2705334 & $8 / 8$ & $\mathrm{Mx}$ & 37.5 & 5.9 & 2.6 & 503 & 7.9861 & 83.6 & 161.1 \\
\hline bh82 & Averages & 581072 & 2706498 & $3 / 3$ & -- & 38.0 & 4.2 & 2.9 & 1,819 & 2.9989 & 85.1 & 167.7 \\
\hline
\end{tabular}


Table 4. Paleomagnetic data for units in northern Harrat Rahat volcanic field, listed alphabetically by unit label within their eruptive stages.-Continued

\begin{tabular}{|c|c|c|c|c|c|c|c|c|c|c|c|c|}
\hline $\begin{array}{l}\text { Unit } \\
\text { label }\end{array}$ & Sample no. & Easting & Northing & N/No & Treatment & Inclination & Declination & a95 & k & $\mathbf{R}$ & Platitude & Plongitude \\
\hline \multicolumn{13}{|c|}{ Eruptive stage 10 (460 to 570 ka) -Continued } \\
\hline bh83 & R15DC049 & 569060 & 2675906 & $8 / 8$ & $\mathrm{Mx}$ & 35.7 & 20.0 & 3.3 & 325 & 7.9785 & 71.4 & 139.6 \\
\hline bha & R16DC006 & 568968 & 2705160 & $7 / 8$ & $\mathrm{Mx}$ & 61.5 & 5.9 & 2.0 & 10,67 & 6.9944 & 71.2 & 53.2 \\
\hline bis & R16DC007 & 568786 & 2705059 & $8 / 8$ & Mx & 43.9 & 351.9 & 2.3 & 619 & 7.9887 & 82.6 & 321.0 \\
\hline bkf & $\mathrm{R} 15 \mathrm{DC} 043$ & 561105 & 2686068 & $6 / 8$ & Mx & 41.7 & 22.2 & 2.8 & 694 & 5.9928 & 69.8 & 125.8 \\
\hline bkf & R16DC045 & 567155 & 2683615 & $7 / 8$ & $\mathrm{Pl}$ & 38.8 & 30.9 & 3.6 & 216 & -- & 61.5 & 128.1 \\
\hline bkf & Averages & 563944 & 2684264 & $2 / 2$ & -- & 40.3 & 26.6 & 15.9 & 251 & 1.9960 & 65.6 & 127.1 \\
\hline bqu & $\mathrm{R} 15 \mathrm{DC} 016$ & 563795 & 2701659 & $8 / 8$ & $\mathrm{Mx}$ & 55.6 & 17.6 & 1.4 & 1,640 & 7.9957 & 70.9 & 87.8 \\
\hline bqu & R16DC023 & 565016 & 2696294 & $8 / 8$ & Mx & 55.9 & 12.3 & 4.4 & 180 & 7.9612 & 74.0 & 78.0 \\
\hline bqu & Averages & 564386 & 2698661 & $2 / 2$ & -- & 55.8 & 15.0 & 6.5 & 1,462 & 1.9993 & 72.5 & 83.3 \\
\hline brg & R14DC025 & 603990 & 2663429 & $7 / 8$ & $\mathrm{Mx}$ & 43.8 & 349.1 & 2.6 & 550 & 6.9891 & 80.0 & 321.1 \\
\hline buph & R17DC004 & 581205 & 2663879 & $6 / 8$ & $\mathrm{Li}$ & -19.6 & 17.2 & 2.3 & 864 & 5.9942 & 51.9 & 191.6 \\
\hline bzi & R15DC045 & 560148 & 2681856 & $7 / 8$ & $\mathrm{Li}$ & 43.2 & 10.3 & 2.6 & 538 & 6.9889 & 80.6 & 122.0 \\
\hline \multicolumn{13}{|c|}{ Eruptive stage 11 (570 to $780 \mathrm{ka}$ ) } \\
\hline bja & R17DC007 & 576552 & 2665348 & $8 / 8$ & Mx & 55.6 & 350.7 & 3.2 & 323 & 7.9783 & 75.5 & 8.3 \\
\hline bsd & $\mathrm{R} 14 \mathrm{DC} 020$ & 589629 & 2664472 & $6 / 8$ & $\mathrm{Mx}$ & -12.3 & 23.1 & 3.4 & 445 & 5.9888 & 52.2 & 180.3 \\
\hline bsl & R16DC049 & 579026 & 2709930 & $7 / 8$ & $\mathrm{Pl}$ & 42.5 & 355.5 & 3.3 & 257 & -- & 85.9 & 312.3 \\
\hline \multicolumn{13}{|c|}{ Eruptive stage 12 (780 to $1,200 \mathrm{ka}$ ) } \\
\hline bgh & R17DC005 & 582332 & 2665868 & $6 / 8$ & $\mathrm{Mx}$ & -45.4 & 181.2 & 2.0 & 1,373 & 5.9964 & -87.0 & 240.8 \\
\hline bgh & R17DC006 & 578630 & 2660720 & $8 / 8$ & $\mathrm{Mx}$ & -38.6 & 182.4 & 2.6 & 484 & 7.9855 & -86.8 & 355.4 \\
\hline bgh & Averages & 580304 & 2663310 & $2 / 2$ & -- & -42.0 & 181.8 & 15.0 & 279 & 1.9964 & -88.3 & 304.0 \\
\hline bh89 & R16DC036 & 574379 & 2690029 & $8 / 8$ & $\mathrm{Mx}$ & -57.1 & 217.1 & 6.4 & 85 & 7.9178 & -55.8 & 277.8 \\
\hline buqa & R17DC016 & 577900 & 2710179 & $5 / 5$ & $\mathrm{Pl}$ & -32.6 & 192.3 & 3.9 & 258 & -- & -76.7 & 338.0 \\
\hline \multicolumn{13}{|c|}{ Unknown eruptive stage } \\
\hline v & R16DC003 & 564614 & 2699736 & $6 / 8$ & $\mathrm{Mx}$ & -35.0 & 176.6 & 7.7 & 107 & 5.9534 & -84.0 & 72.0 \\
\hline v & R16DC004 & 566741 & 2702481 & $9 / 9$ & Mx & 45.9 & 2.0 & 3.6 & 234 & 8.9658 & 86.6 & 71.4 \\
\hline
\end{tabular}

